Florida International University FIU Digital Commons

FIU Electronic Theses and Dissertations

University Graduate School

$11-8-2010$

\title{
Left Behind: A Farmer's Fate in the Age of Sustainable Development
}

Cristian J. Melo

Florida International University, cmelo003@fiu.edu

DOI: $10.25148 /$ etd.FI10120302

Follow this and additional works at: https://digitalcommons.fiu.edu/etd

\section{Recommended Citation}

Melo, Cristian J., "Left Behind: A Farmer's Fate in the Age of Sustainable Development" (2010). FIU Electronic Theses and Dissertations. 331.

https://digitalcommons.fiu.edu/etd/331

This work is brought to you for free and open access by the University Graduate School at FIU Digital Commons. It has been accepted for inclusion in FIU Electronic Theses and Dissertations by an authorized administrator of FIU Digital Commons. For more information, please contact dcc@fiu.edu. 


\section{FLORIDA INTERNATIONAL UNIVERSITY}

Miami, Florida

LEFT BEHIND: A FARMER'S FATE IN THE AGE OF SUSTAINABLE DEVELOPMENT

A dissertation submitted in partial fulfillment of the requirements for the degree of DOCTOR OF PHILOSOPHY

in INTERNATIONAL RELATIONS

by

Cristian Javier Melo 
To: Dean Kenneth Furton

College of Arts and Sciences

This dissertation, written by Cristian Javier Melo, and entitled Left Behind: A farmer's fate in the Age of Sustainable Development, having been approved in respect to style and intellectual content, is referred to you for judgment.

We have read this dissertation and recommend that it be approved.

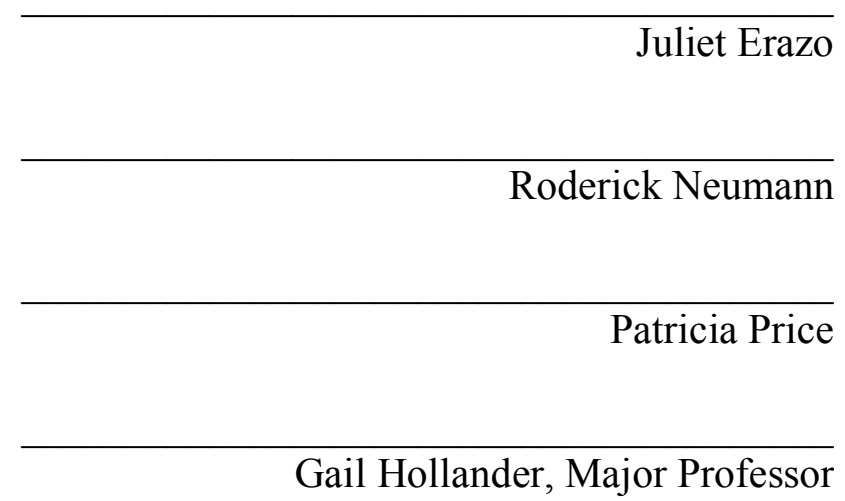

Date of Defense: November 8, 2010

The dissertation of Cristian Javier Melo is approved.

Dean Kenneth Furton

College of Arts and Sciences

Interim Dean Kevin O'Shea

University Graduate School

Florida International University, 2010 


\section{(C) Copyright 2010 by Cristian Javier Melo}

All rights reserved. 


\section{DEDICATION}

To Nora and Luciana. 


\section{ACKNOWLEDGMENTS}

This project was conducted thanks to the support of a Florida International University Graduate School Dissertation Evidence Acquisition Fellowship (2009) and a Dissertation Year Fellowship (2010). Fieldwork was supported with a grant from Florida International University Latin American and Caribbean Center, and the Tinker Foundation, Inc; a grant by the South Florida Chapter of The Explorer's Club, and a grant from FIU Agroecology Program under the USDA-CSREES Grant Number 2006-5116003409. This research project was approved by FIU Internal Review Board (Approval\# 022009-01).

The author acknowledges the teachings, insights, support and help of my advisor Dr. Gail Hollander. It has been a fruitful relationship. I also express my thanks to Dr. Juliet Erazo, Dr. Roderick Neumann, and Dr. Patricia Price for their suggestions and time. I also express my thanks to the faculty, fellow students, and administrative staff of Florida International University Department of International Relations and of the Department of Global and Sociocultural Studies. Thanks to Dr. Elisabeth Prugl, Dr. Laura Ogden, Dr. Thomas A. Breslin, Dr. Paul Kowert, and Dr. Richard Tardanico. Of the FIU community at large, I grateful for the help and support from Dr. Mahadev G. Bhat, Dr. Jennifer Gebelein, and Dr. Maureen Donnelly.

The author acknowledges the support of Agr. Victor Chacon, Ec. Christian Pineda, Ing. Rosa Paucar, Ing. Cesar Carrillo, Ing. Danilo Pluas, Justo Paucar, Domingo Mendoza, Pedro Flores, Juan Azanza and other members of the Federacion de Productores de Cacao del Ecuador. Better times will come. The author also acknowledges Ing. Julio Cerezo, Gerardo Molina, Ing. Ana Nivela, and the farmers of the Asociacion of 
Productores Organicos de Vinces. Thanks to Ing. Gardenia Gonzalez from the University of Guayaquil at Vinces; Ec. Julio Zambrano (COFINA); Ing. Pedro Martinetti (Exp. Martinetti); Ing. Gonzalo Romero (REPEC); Ing. Xavier Elizalde (ANECACAO); Jose Valdivieso, Rocio Aucancela, Alfredo Duenas, Juan Lecaro, Franz Rios and Felipe Noboa — current and former officials of Conservation and Development cocoa project; from the chocolate world, thanks to Pierrick Chouard, Shawn Askinosie, Clark Goble, and Mark Christian; and to William Foote, from Root Capital.

A special thanks to the cocoa farmers (from South to North) of Rosalino Ortega, Frutas Tropicales, El Progreso, 3 de Octubre, La Florida, Camacho, Luz y Guia, 6 de Julio, Nueva Union, Jesus Maria, Manglar Alto, Vinces, Abdon Calderon, Quevedo, Mochache, and Puerto Limon. A special thank you to the Chacon Family at Jesus Maria for their hospitality and support during field work. My eternal thanks to Doña Luli and Marcia for taking care of a typhoid-dengue-stricken researcher.

Finally, I acknowledge the amazing support and help of my wife, Nora Oleas. I dedicate this dissertation to her-as I did with my M.Sc. and with my B.Sc. thesis—for her immeasurable support. Thanks my brother, Carlos Melo, my wonderful in-laws, and the rest of my family. 
ABSTRACT OF THE DISSERTATION

LEFT BEHIND: A FARMER'S FATE IN THE AGE OF SUSTAINABLE

DEVELOPMENT

\author{
by \\ Cristian Javier Melo \\ Florida International University, 2010 \\ Miami, Florida

\section{Professor Gail Hollander, Major Professor}

Globalization is eroding the livelihoods of small farmers, a significant and vulnerable class, particularly in the developing world. The cost-price squeeze stemming from trade liberalization places farmers in a race to the bottom that leads to displacement, poverty, and environmental degradation. Scholars and activists have proposed that alternative trade initiatives offer a unique opportunity to reverse this trend by harnessing the power of the markets to reward producers of goods with embedded superior cultural, environmental, and social values. Alternative trade via certification schemes have become a de facto prescription for any location where there is a need to conciliate economic interest with conservation imperatives.

Partnerships among commodity production farmers, elite manufacturers and wealthy northern consumers/activists do not necessarily have win-win outcomes.

Paradoxically, the partnerships of farmers with external agencies have unexpected results. These partnerships develop into dependent relationships that become unsustainable in the absence of further transfers of capital. The institutions born of these partnerships are fragile. When these fledging institutions fail, farmers are left in the same situation that 
they were before the partnership, with only minor improvements to show after spending considerable amounts of social and financial capital.

I hypothesize that these failures are born out of a belief in a universal understanding of sustainability. A discursive emphasis on consensus, equity and mutual benefit hides the fact that what for consumers it is a matter of choice, for producers is a matter of survival. The growth in consumers' demand for certified products creates a race for farmers to meet these standards. My findings suggest that this race generates economically perverse effects. First, producers enter into a certification treadmill. Second, the local need for economic sustainability is ignored. Third, commodity based alternative trade schemes increase the exposure of communities to global shocks. I conclude by calling for a careful reassessment of sustainable development projects that promote certification schemes. The designers and implementers of these programs must include farmers' agenda in the planning of these programs. 


\section{TABLE OF CONTENTS}

CHAPTER

PAGE

I. INTRODUCTION 1

$\begin{array}{lr}\text { Literature review } & 10\end{array}$

$\begin{array}{ll}\text { Methods } & 16\end{array}$

$\begin{array}{ll}\text { The narratives of chocolate: collection and analysis } & 16\end{array}$

$\begin{array}{ll}\text { Field work } & 18\end{array}$

$\begin{array}{ll}\text { Survey data analysis } & 23\end{array}$

$\begin{array}{ll}\text { References } & 28\end{array}$

II. LIVING FROM THE FUMES OF THE PAST: ECUADORIAN COCOA AND THE BRAVE NEW WORLD OF CHOCOLATE BRANDING 33

Introduction and Background 33

Issues of cocoa production $\quad 35$

Ecuador's cocoa: Living from the fumes of the past? 41

$\begin{array}{ll}\text { The bars: collecting chocolate } & 47\end{array}$

Cocoa from Ecuador, chocolate from all over the world 48

On-bar narratives: addressing issues in cocoa production 49

Single origin, varietals, and craftsmanship $\quad 49$

Who is behind fine chocolate: farmers or manufacturers? 50

Ethical and environmental sourcing: small farmers and shade-grown

cocoa. $\quad 54$

Single-origin on the cheap $\quad 56$

$\begin{array}{ll}\text { References } & 67\end{array}$

III. ON THE PATH OF SUSTAINABLE DEVELOPMENT 73

$\begin{array}{ll}\text { Introduction and Background } & 73\end{array}$

Methods $\quad 75$

Ecuador's Federation of Cocoa Producers: then and now 78

Investing for development I: Infrastructure; Training and Extension, and

Research and Development, 1995-2008 86

Investing for development II: commercialization, 2002-2008 89

The [unexpected] results of development projects 96

Lessons learned: shades of gray in a development program 103

$\begin{array}{ll}\text { References } & 116\end{array}$

IV. COCOA FARMER'S LIVELIHOOD STRATEGIES 121

$\begin{array}{ll}\text { Introduction and Background } & 121\end{array}$

Between a rock and a hard place: Ecuador's cocoa production dilemma $\quad 122$

$\begin{array}{ll}\text { Methods } & 132 \\ & 138\end{array}$

$\begin{array}{ll}\text { Cocoa farmer profiles } & 138\end{array}$

Farm description: holdings, varieties, and yields 139 
The economics of farmers' decisions: shade-grown but low yield vs. fullsun but high yield

Crop diversification and on-farm income

On-farm production cost and farm gross agricultural income

Agricultural income and poverty level

Risk reduction: Farmers perception about Nacional and CCN-51

The Secret [Economic] Life of Cocoa Farmers: holding four hats

Arriba: An unsustainable crop?

V. CONCLUSION

\section{APPENDICES}




\section{LIST OF TABLES}

TABLE

PAGE

\section{CHAPTER II}

1 Chocolate bars by brand, origin, \% of cocoa, and country of origin of manufacturer

\section{CHAPTER II}

1 Chocolate bars by brand, $\%$ of cocoa solids, manufacturer and country of origin of manufacturer

2 Sources of cocoa, number of bars, scale of sourcing, place, and area (in sq $\mathrm{km})$ of place.

\section{CHAPTER III}

1 Investing in FEDECADE: Year of execution, project title, donors, and project amounts in US\$.

2 Average commercialization parameters for FEDECADE commercialization system, 2003 to 2007.

3 Expenses; sales; profit and loss, and estimated revenue (in US\$) for farmers for FEDECADE commercialization system, 2003 to 2007.

4 Profit and loss margin 2003-2008 for all cooperatives and associations involved with FEDECADE commercialization system

\section{CHAPTER IV}

1 List of farmer's associations (FA), Ecuadorian government agencies (GA), intergovernmental organizations (IGO), projects (LFP), local government associations (LGA), non-governmental organizations (NGO), private agencies (PA), public/private sector partnerships (PPP), and Universitylevel Educational Institutions (UEI) that have worked in Nacional related cocoa projects, 2006-2008

2 On-farm and off-farm sources of income FEDECADE and APOV farmers. 
3 Crops systems, number of farmers, standardized farm gross product (FGP) (in US\$/ha year), proportion of FGP from each crop, standardized farm gross income (FGI) in (US\$/ha year) and rank of that cropping systems for FEDECADE and APOV.

4 Crop (by farmer's organization), yield (as reported and in standard units) gate price (as reported and in standard units), production cost (as reported and in standard units)

5 Area (ha) by cropping system and farmer's association needed for farmer's agricultural gross income to be above Ecuador's extreme poverty level $(\mathrm{CFV})$ and poverty level (CFB)

6 Regression analysis equations for agricultural gross income (US\$) by area (ha) by cropping system and farmer's association. 


\section{LIST OF FIGURES}

FIGURE

PAGE

\section{CHAPTER I}

1 Area of Study. Ecuador, the Western lowlands (Costa), APOV and FEDECADE associations and cooperatives.

2 Formulas to calculate (a) standardized Farm Gross Product (FGP in US\$ ha/year) and (b) standardized Farm Gross Income (in US\$ ha year)

\section{CHAPTER II}

1 Price by weight of cocoa beans (in US\$ per tonne), 2004-2007, showing price differential for fine versus bulk cocoa beans.

2 World's cocoa area harvested (in thousands of ha), production (in thousand tonnes) and price per weight (in US\$ per tonne), 1961-2009.

3 Cloud tag for 75 most common terms (other than brand names) found in the wrappers of 27 chocolate bars made with Ecuador's, "Arriba" or Nacional cocoa beans. Size of font is proportional to the number of cases where a particular world was found $(n=27)$.

\section{CHAPTER III}

1 Area of Study. Ecuador, the Western lowlands (Costa), APOV and FEDECADE associations and cooperatives.

2 Ecuadorian cocoa production statistics, 1961-2009. (a) Area harvested (ha/year). (b) Production by year (tonnes/year). (c) Yield by area ( $\mathrm{kg} / \mathrm{ha} /$ year).

3 FEDECADE profit and loss margin as \% of sales box plot for all associations/cooperatives by year, where marks average profit and loss margin, box is represents 1 st and 3rd quartile, and error bars show interassociations variability.

\section{CHAPTER IV}

1 Ecuadorian cocoa production statistics: a) production by area harvested, 1964-2009; b) production by area (kg/ha), 1969-2009. 
2 Area of Study. Ecuador, the Western lowlands (Costa), APOV and FEDECADE associations and cooperatives.

3 Formulas to calculate (a) standardized Farm Gross Product (FGP in US\$ ha/year) and (b) standardized Farm Gross Income (in US\$ ha year)

4 Histogram for the frequency of farmer's age (in years) for (a) FEDECADE $(\mathrm{n}=100)$ and (b) APOV $(\mathrm{n}=60)$.

5 Standardized Farm Gross Product (FGP) and standardized Farm Gross Income (FGI) (in US\$ /ha year) by crop system by Farmer's Organization.

6 Regression analysis for yearly agricultural gross income (US\$) by area (ha) by cropping system for FEDECADE farmers, with guides for yearly Family Vital Income Level (CFV) and Family Basic Level (CFB).

7 Regression analysis for yearly agricultural gross income (US\$) by area (ha) by cropping system for APOV farmers, with guides for yearly Family Vital Income Level (CFV) and Family Basic Level (CFB

8 Dot plot for FEDECADE farmers with incomes below and above Ecuadorian poverty level (CFB) by area of holdings (ha).

9 Dot plot for APOV farmers with incomes below and above Ecuadorian poverty level (CFV) by area of holdings (ha).

10 Tree of cacao Nacional, Nueva Union Campesina, Guayas, 2009

11 Tree of CCN-51 cacao, Nueva Union Campesina, Guayas, 2009 


\section{LIST OF ABBREVIATIONS}

TERM

Agency for International Development of United States of America

Agricultural Cooperative Development International and Volunteers in Overseas Cooperative Assistance

Asociacion de Productores Organicos de Vinces

Asociacion Nacional de Exportadores de Cacao

British Broadcasting Corporation

Bundesverband Großhandel, Außenhandel, Dienstleistungen

e.V. [Federation of German Wholesale and Foreign Trade]

Canasta Familiar Basica (Ecuador's poverty level)

Canasta Familiar Vital (Ecuador's extreme poverty level)

Chocolates Finos Nacionales (cocoa exporter)

Coleccion Castro Naranjal [cacao collection]

Corporación de Promoción de Exportaciones e Inversiones

Corporation Integral of Associations of Camilo Ponce

Enriquez

Department of State

Deutsche Entwicklungsdienst [German Development

Service]

Deutsche Gesellschaft für Technische Zusammenarbeit

[German Agency for Technical Cooperation]

Dutch Postcode Lottery DOEN Foundation
ABBREVIATION

USAID

ACDI/VOCA

APOV

ANECACAO

$\mathrm{BBC}$

BGA

CFB

CFV

COFINA

$\mathrm{CCN}$

CORPEI

CIACPE

USDS

DED

GTZ

DOEN 
El Nino Southern Oscillation

ENSO

El Progreso (farmers' association)

PRO

Estacion Experimental Tenguel [cacao collection]

EET

Farm Gross Income (standarized)

FGI

Farm Gross Product (standarized)

FGP

FEDECADE Trust Fund for Commercialization of Cocoa

FTFCC

Federacion de Productores de Cacao del Ecuador

FEDECADE

Fideicomiso Ecuatoriano para el Desarrollo [ex: Fondo

Ecuatoriano Canadiense para el Desarrollo]

FECD

Food and Agriculture Organization

FAO

Free on board

FOB

Frutas Tropicales (farmers' association)

FRT

Fundacion Alianza CEIDE [ex: Corporacion de Conservacion

y Desarrollo (CCD); Conservacion y Desarrollo]

CYD

Gross Agricultural Income

GAI

Gross profit and loss margin

GPLM

Hectare

ha

Imperial College Selection [cacao collection]

ICS

Industria Cioccolato Affini Morbegno

ICAM

Instituto Autonomo de Investigaciones Agropecuarias

INIAP

Instituto Ecuatoriano de Estadisticas y Censos

INEC 
Instituto Ecuatoriano de Normalizacion

INEN

Instituto Ecuatoriano de Propiedad Intelectual

IEPI

Instituto Nacional Autónomo de Investigaciones

Agropecuarias

INIAP

Inter gubernamental organization

IGO

International Cocoa Initiative

ICI

International CocoaOrganization

ICCO

Kilogram

$\mathrm{kg}$

Kilometer

$\mathrm{km}$

La Florida (farmers' association)

LFL

Liquid Petroleum Gas

LPG

Metric tonne

MT

Multinational corporation

$\mathrm{MNC}$

National Confectioners Association

NCA

Non guvernamental organization

NGO

Nueva Union Campesina (farmers' association)

NUC

Organic Techonolgical Package

OTP

Pound's Iquitos Mixed Calabacillo [cacao collection]

IMC

Programa de Modernizacion de los Servicios Agropecuarios

PROMSA

Programa Nacional del Cacao

PNCC

Protected Denomination of Origin

PDO 
Proyecto de generacion de ingresos y empleo para la frontera norte del Ecuador [US AID]

PRONORTE

Quintales (100 pounds, $45.45 \mathrm{~kg}$ )

$\mathrm{qq}$

Rainforest Alliance Certified

RA

Recinto Camacho (farmers' association)

CAM

Rosalino Ortega (farmers' association)

ROS

Scavina [cacao collection]

SCA

Seis de Julio (6 de Julio) (farmers' association)

6DJ

Sistema de Capacitación en el Manejo de los Recursos

Naturales Renovables

CAMAREN

Standard deviation

SD

Swiss Agency for Cooperation and Development

SDC

Tonne (metric tonne)

Tonne

Tres de Octubre (3 de Octubre) (farmers' association)

$3 \mathrm{DO}$

Union Nacional de Organizaciones Campesinas Cacaoteras del Ecuador

UNOCACE

Union Regional de Campesinos del Litoral

UROCAL

United States

US

US Dollar

US\$ 


\section{CHAPTER I.}

\section{INTRODUCTION}

My interest in the sustainable flavor of development dates back to 1995, when I joined the Ecuadorian non-profit organization then known as Corporacion de Conservacion y Desarrollo (CYD). At the time, I was a surveyor/data processor/analyst/extensionist/porter for the MDs hired for a USAID child-nutrition project in the North of the Province of Esmeraldas, Ecuador. Biologists were cheaper than Doctors, we had experience working in remote areas, and we could do statistics and programming in a pinch. We could also weigh babies.

I remember the faces of those children today. One week, they were healthy and growing. They were smiling, and making eye contact, and weighing them was like herding cats: babies do not like to stay in one place when the world is so large and there are so many things to do. I remember writing weights in a color-coded growth charts, giving proud mother a smiley face sticker, dispensing a bottle of vitamins and minerals (if available), and promising to get back in a month (or so). Sometimes the next month, things were not so rosy. Disease and generic malnutrition take a toll on those babies. A cold turns into pneumonia, diarrhea weakens them, malaria and typhoid double-whammy kills them. The noisy, funny and happy baby of one visit became a sickly tired little human being, struggling to get air into his or her lungs. Some of them got better. Some of them lost the fight.

When a baby dies, the tradition of Esmeraldas' Afro Ecuadorian is that women mourners sing the baby farewell early in the morning. The combination of twilight, the hypnotic sounds of percussion instruments, and women's voices embedded with sadness 
generate a chant - a memory burned in my brain. While poverty in Esmeraldas has many roots, I saw a correlation between the activities of logging companies and the frequency of Arrullos. In Esmeraldas - as in other places - poverty and industrial-level timber and hardwoods extraction go hand in hand. Once the forest is gone, there is no longer food on the table.

After looking at the effects of poverty, I embraced sustainable development as the only alternative to tame wild capitalism. I was involved in projects ranging from Ecotourism to Ecocertification, all of them with the ultimate goal of fighting poverty and increasing the welfare of people by engaging consumers who were willing to pay premiums for environmentally and socially superior goods. I saw certification as a tool for change. It provided a framework for cleaning banana production, while providing workers with the guarantees and services above the minimum provided by Ecuadorian Banana production bylaws. It was useful for regulating environmental impacts of tourism in Galapagos, while addressing issues about the impact of human activity on the social structure of the communities there. In addition, I saw that certification had the potential to create a market for small-farmers' shade-grown cocoa.

My involvement with this initiative started with a 1997 visit to the El Progreso Association of Cocoa Producers, then a member of the Ecuadorian Federation of Cocoa Producers. At the time, what I saw had an eerie resemblance to other areas. Small farmers were losing their shaded Nacional farms, burdened as they were by the impacts of the 1997-1998 El Nino. Land consolidation and land cover change was proceeding at what I saw was an alarming pace. Given that cocoa prices were at historical lows, some farmers sold their shaded cocoa farms. The new owners converted the land to bananas. Farmers 
resorted to extracting whatever timber trees they had on their farms - just to see how intermediaries pay them miserly values for princely hardwoods or for the scarce cocoa extracted from their flooded plantations. Young people left their communities, to become immigrants abroad. From a conservationist perspective, this was a nightmare scenario given that shaded cocoa farms were the habitat of whatever remained of the biodiversity of the region. From my own perspective, natural resources degradation, land consolidation, displacement, and poverty came hand in hand.

As part of the CYD Rainforest Alliance certification department, and later as the interim Co-director of this department, I saw certification as a tool to link environmental, economic and social development. For example, the certification norms called for phasing out fuel-wood-based cocoa-bean driers. LPG-based driers were too expensive for individual farmers, so I directed a small research project to design and test a solar drier made with greenhouse plastic and locally available materials. These solar driers were an instantaneous hit. These solar driers allowed farmers to ferment and dry cocoa even under a drizzle, a common occurrence at the time of harvest. Selling dried or semi-dried cocoa increased family income, by reducing the margin of discount imposed by intermediaries.

By 2002, at the time I left Ecuador to continue my studies, the cocoa project was full of promise. In the time it took me to earn my Master's, three things happened that suggested this initiative would come to full bloom. First, by late 2004 the Rainforest Alliance certified farmers affiliated with FEDECADE were receiving a premium of $26 \%$ over the market price (about $\$ 1900$ per MT when the Ecuadorian FOB market price was $\$ 1505$ per MT). Second, there was a race to certify and to add certifications on top of one another. The premiums and markets for Organic were said to be better than the premiums 
for Rainforest Alliance certified cocoa, thus FEDECADE was looking to add organic certified cocoa to its products line. It also was looking for achieving Fair Trade certification, which was portrayed as the ultimate certification tool for small farmers. Third, CYD and Citigroup launched FEDECADE's Cocoa Trust Fund, which was to inject capital in FEDECADE's commercialization system.

It took me three years to get back to FEDECADE. When I was conducting preliminary research in December 2007, FEDECADE commercialization system had had a record year. However, the profits margin for Rainforest Alliance, Organic and Fair Trade certified cocoa were lower. Some farmers - who have been stalwarts of certification efforts - had dropped out of the commercialization system after realizing that "keeping the system working" was not worth the trouble. Furthermore, the cost of establishing a CCN-51 plantation was lower and some of them spoke about the value of combining CCN-51 with passion fruit, oranges, and other crops. The compelling argument of a farmer was that "having more than one source of income was better." I saw a similar phenomenon in my visit to the Association of Organic Producers from Vinces (APOV). The income of the APOV farmers was boosted by selling organic bananas from banana trees grown within Nacional cocoa farms.

Thus, when I set out to gather the data for my dissertation, I did not expect the FEDECADE commercialization system to come from a halt as it did in 2009. I did not foresee a collapse of the organic market, or the downward premium spiral created as more cocoa farmers became certified under Rainforest Alliance. The main goal of my dissertation changed from a comparative assessment of the benefits of certification schemes and community networking to an analysis of why certification-oriented projects 
have failed. I was able to change my perspective because of my exposure to readings on critical literature of development, globalization, and neoliberalism, and combine them with my previous scholarly work in Natural Resources Management. This work, a snapshot in time, shows that change. In the writing of my dissertation, I have struggled to show farmer's perspectives and outcomes. In fact, certification - the implementation of sustainable development initiatives — can generate improvements in the livelihoods of farmers. However, these changes are not necessarily permanent, nor guaranteed. I see that the path of sustainable development is painted in shades of gray. Farmers-successful gamblers as they are-finally succeeded in teaching me to see the world of cocoa through their eyes. Environmental sustainability is a worthwhile endeavor, but it must be accompanied by economic development. Furthermore, economic development-at the family level—is necessary for insuring social justice in a capitalistic society, given that money provides welfare - and a certain protection against the rapacity of capitalism — in the absence of a radical transformation of society.

My study starts by questioning the conventional wisdom that holds that partnerships among commodity production farmers, elite manufacturers and wealthy northern consumers/activists have win-win outcomes. Paradoxically, although alternative trade offers communities opportunities to capitalize on the environmental benefits afforded by traditional agricultural practices, the partnerships of farmers with external agencies often have unexpected results. I hypothesize that these failures are born out of a belief in a universal understanding of sustainability (Luke 2005). A discursive emphasis on consensus, equity and mutual benefit (Ashman 2001) hides the fact that what for consumers it is a matter of choice, for producers is a matter of survival (Moberg 2005). 
Thus, while consumers express choice, farmers have no choice but to join alternative trade networks - and follow the mandates of these trading schemes - if they are to get access to the benefits that come from international investment (Melo and Wolf 2007). The growth in consumers' demand for ecologically and socially labeled products creates a race for farmers to meet these standards.

Furthermore, I argue that this race generates perverse effects. First, producers are forced to enter into a global 'certification treadmill.' As described by Cochrane (1958) for agricultural innovation, early adopters reap benefits out of introducing new practices but as more and more latecomers join in, farmers' face diminishing returns. To sustain viability, farmers must race to adopt scheme after scheme, courting consumers as these 'global citizens' add layers of 'desirability' to their wish lists (Seyfang 2005). Second, the race to meet consumers' desires for 'superior' goods ignores the local need for economic sustainability. The superiority of alternative goods depends on meeting the ecological perceptions of consumers. Under the lure of premiums, farmers are induced to forfeit changes that would have increased the profitability of their farms. Third, even when successful, commodity based alternative trade schemes increase the exposure of communities to global shocks. Capital investments and premiums for one commoditythe alternative one — lead farmers to forfeit crop diversification strategies, colloquially "putting all their eggs in one basket." Nevertheless, as in the case with other commodities, when the production of certified goods outpaces demand premiums collapse.

The goal of this study is to spotlight some of the shortcomings of alternative trade. I explore the tensions and contradictions between local needs and globalized ideals 
that play out in the context of sustainable development initiatives. For this, I present a case study based in the Ecuadorian shade-grown cocoa known as Nacional, and generally marketed as "Arriba." Nacional is a genetically distinctive fine cacao variety with a unique floral aroma and flavor given by a combination of farming practices, climate, soil and luminosity that occurs exclusively in the shaded cacao farms of Ecuador's coastal lowlands (Motamayor et al. 2008; Deheuvels et al. 2004; Loor et al. 2009; Lerceteau et al. 1997; Cambrai et al. 2010). The production of these highly appreciated beans is declining, even in the face of substantial investments to develop alternative trade networks that reward farmers that preserve this variety.

This study was designed to address the paradox of decreasing output in view of increasing investment and interest. I examine how the agendas of farmers, chocolate manufacturers, and development agencies come into play in the setting of Ecuadorian Nacional cacao production. The study looks at places where certification schemes/sustainable development projects have been implemented. By asking questions about connectedness, comparing understandings of sustainability, and establishing the local cost and benefits of sustainability alliances, I examine the reasons behind the decline of Nacional cacao production even in cases where communities have received support designed to stop this loss.

The present study has three lines of inquiry. The first is to study the connections between local Nacional cacao producers and their global partners, as mediated, on the one hand, by certification and labeling and, on the other, by the shape and structure of each community's 'sustainability network' (Halme 2001). The second is to establish the differences between farmers' and non-farmers' (i.e., development agencies) discourse 
about the decline of Nacional production and possible solutions. The third is to compare local understandings of the challenges and benefits of sustainability with those of nongovernmental organizations (NGOs), intergovernmental organizations (IGOs) and other institutions/actors involved in the Nacional cacao problematic.

My study describes the responses of communities to sustainability-informed alliances, and under which social, environmental and economic tradeoffs these partnerships operate. The results of this study show how sustainable development practitioners have constructed romantic visions of farmers. I explore how this idealization does not do justice to the complexity of a farmer's socio-economic life.

My dissertation is organized as follows. Chapter I contains the Introduction, Literature review, and Methods. The dissertation body is composed of Chapter II, III, and IV. Each of these chapters is conceived as a publishable, independent journal article. In Chapter V, I summarize my findings and present my concluding remarks.

I have three overarching aims. I address each aim in one of the main chapters of the document. The first aim is to elicit what chocolate manufacturers think consumers are looking for-what are the qualities that make alternative goods. Thus, in Chapter II I present a case study of the demand side the commodity chain. To understand what values are marketed to the consumers of chocolates, I studied the narratives printed on the packaging material of chocolate bars that are marketed as made of a high percent $(>50 \%)$ of Arriba, Ecuadorian Nacional, or Ecuador's cocoa beans. My findings suggest that market forces encourage manufacturers to make ever more environmentally and socially progressive claims on their products. However, the link between progressive marketing and benefits for the farmers is tenuous at best. 
The second aim is to understand how manufacturers' perception of consumers demand are transferred to cocoa farmers. In Chapter III, I present the results of the analysis of the alliance between Ecuador's Federation of Cacao Producers (Federacion Nacional de Productores de Cacao del Ecuador, FEDECADE), its Ecuadorian NGO counterpart (currently known as Fundacion Alianza CEIDE or CYD), and a heterogeneous set of international donors. These projects spanned 10 years (1997-2008), and nominally invested roughly US\$1200 for each of the farmers involved (US\$ $1,436,738$ per 1172 families) with the goal of creating an alternative commercialization system for Nacional. The key strategy for achieving this goal was to increase farmers' incomes by improving farmers' access to the markets. This project was leveraged in the unique "fine and flavored" quality of the Nacional beans, under the assumption that highend chocolate makers would be willing to pay a higher price for value-added beans. For six years (2003 to 2008), the project delivered higher-than-average prices for certified Nacional. However, in 2009 FEDECADE's commercialization system ceased to operate. In this Chapter, I address the reasons for this failure. I use data from interviews, and information available in the archives of FEDECADE and CYD, to establish the factors that determined the fate of the commercialization project. I found that the FEDECADE project of developing alternative markets for its cocoa was in fact successful. However, the success of the project also exposed FEDECADE to risks that lead to the ultimate collapse of the initiative.

The third aim is to understand how farmers make their decisions about growing cocoa and other crops. In Chapter IV, I use survey data to analyze the economics that lie behind farmer's choices. In this chapter I compare the income that small farmers derive 
from Nacional and CCN-51 cocoa plots. I frame the results comparing two farmer's associations, one of which (APOV) is actively selling certified organic and Rainforest Alliance cocoa, and other where farmers are selling cocoa through local markets (FEDECADE). I also include the income of crops grown with cocoa, as well as those that are cultivated independently. I also analyze the role of farm employment in cocoa farmers' livelihood. Finally, I address the issues surrounding why a farmer selects a given variety. My findings suggest that the arguments of non-farming actors such as NGOs and IGOs do not truly reflect the complex choices and options that farmers face on a day-today basis, nor effectively address the economic tradeoffs of these views.

\section{Literature review}

Globalization is eroding the livelihoods of small farmers, a significant and vulnerable class, particularly in the developing world. The cost-price squeeze stemming from trade liberalization places farmers in a "race to the bottom" that leads to displacement, poverty, and environmental degradation (Porter 1999). Scholars and activists have proposed that alternative trade initiatives offer a unique opportunity to reverse this trend by harnessing the power of the markets to reward producers of goods with embedded superior cultural, environmental, and social values (Goodman and DuPuis 2002; Bryant and Goodman 2004; McMichael 2000). Policy makers — influenced by the narrative of 'sustainability through consumption' - attempt to solve allocation issues by fomenting partnerships that encourage products that cater to the sensibilities of the Northern activist consumers (Bryant and Goodman 2004). Proponents of these systems argue that they offer a unique opportunity to harness the power of markets to protect the social, cultural, economic and environmental benefits provided by traditional cropping 
systems. Alternative trade networks are visualized as institutional arrangements through which the benefits generated by small-scale, low-input agricultural producers are valorized (Moberg 2005; Gómez Tovar et al. 2005; Brown and Getz 2008). Consumers get access to high-quality, traceable (safe) and ecologically/ethically superior goods; manufacturers and dealers get access to an attractive niche-market, and producers are compensated with economic premiums for the environmental and social services of their crops (McMichael 2000; Murray and Raynolds 2000; Rice 2001; Ponte 2002; Raynolds 2002). Thus, alternative trade networks create 'partnerships of virtue' that challenge the transnationally dominated global food system (McMichael 2000). These new mechanisms of trade - mediated by certification labels that inform consumers that the product carries attributes that set it apart from its counterparts—are thought of as consensual partnerships of producer and consumers. Thus, the labels are symbols that overcome the distance that separate producers and consumers since the late eighteenth century development of worldwide trade (Polanyi 1941).

Alternative trade and third-party certifications have become a de facto prescription for any location where there is a need to conciliate economic interest with conservation imperatives. The wide adoption of this sustainable development tool is understandable. Certification schemes allow their proponents to link capitalist logic and economic self-interest to sustainability imperatives by creating niche markets for products with higher environmental, social or geographical ratings (Goodman and DuPuis 2002; Hayes, Lence, and Stoppa 2004; Bramley and Kirsten 2007; Taylor 2005). The need for these private actions was born in an era in which globalization and neoliberalism advanced an agenda of deregulation, privatization, and liberalization of 
commerce that dismantled nation-states' ability to regulate natural-resources-based economic sectors (Barbier 2000; Barbier 2003; Barbier 2004; Sonnenfeld and Mol 2002; McCarthy 2004). Considering the loss of faith in state-based regulation, scholars and activists opted for developing environmental governance arrangements that increase consumers' awareness of linkages between consumption and the impacts of production. These tools, which allow consumers to 'vote with their wallets,' convert the act of shopping in an exercise into global ecological and ethical citizenship, thus feeding the advancement of environmentally and socially progressive agendas (Clarke et al. 2007; Seyfang 2005).

Conservation-oriented studies have shown that shade-grown cocoa—as other agro forestry systems - provides a refuge for local biodiversity and critical ecosystem services (Clough, Faust, and Tscharntke 2009; Steffan-Dewenter et al. 2007; Franzen and Mulder Borgerhoff 2007; Rappole, King, and Rivera 2003; Donald 2004; Gobbi 2000; Bisseleua, Missoup, and Vidal 2009; Schroth and Harvey 2007; Dahlquist et al. 2007; Harvey et al. 2007). These studies show that the ecological benefits of cocoa plantations are lost if these fields are converted to full-sun cocoa or other cropping systems such as bananas (i.e., Clough, Faust, and Tscharntke 2009). Full-sun cocoa trees are said to be short lived and dependent on fertilizers and irrigation; furthermore, farmers with full-sun holdings are said to be more likely to use agrochemicals like herbicides and pesticides (Bentley, Boa, and Stonehouse 2004; Donald 2004). However, the empirical evidence to sustain some of these claims is lacking. For instance, when an Ecuadorian farmer reportedly said that he believed that CCN-51—a local high-yield, full-sun, hybrid cocoa - "could live for more than 50 years" the article's author comments that "this would appear highly 
unlikely" without explaining the reasons behind the author's belief (Bentley, Boa, and Stonehouse 2004: 260).

Nevertheless, the agricultural yield of shade-grown cocoa is lower than that of these full-sun systems (Franzen and Mulder Borgerhoff 2007; Donald 2004). In fact, in a study in Cameroon, scientists found that "yield significantly decreased with increased shade cover (Bisseleua, Missoup, and Vidal 2009). In Ecuador, there is a study that shows that intensively-managed high-yield hybrid cocoa variety have yields of $4000 \mathrm{~kg}$ of dry cocoa beans per ha year, compared to $900 \mathrm{~kg}$ per ha year for "fine [shade-grown] cocoa under the best conditions" (Espinosa et al. 2006). In view of this marked productivity difference, scientists routinely propose the use of certification schemes to encourage farmers to preserve these low yield ecologically rich systems (SteffanDewenter et al. 2007; Bentley, Boa, and Stonehouse 2004). Similarly, calls for implementing certification programs are made in practically all the areas in all the tropics where cocoa is raised (i.e., Indonesia (Steffan-Dewenter et al. 2007), Cameroon (Bisseleua, Missoup, and Vidal 2009), Ecuador (Bentley, Boa, and Stonehouse 2004), and Mexico (Greenberg, Bichier, and Cruz Angón 2000)).

There is an increasing body of critical literature that addresses the conceptual failings of alternative trade as visualized by environmentally-oriented scientists. Consumption-based efforts - such as certification — respond to Northern definitions of sustainability. Generally speaking, the bodies that regulate certification have their headquarters in the 'North' (for example, Rainforest Alliance headquarters are in New York, Fairtrade Labeling Organization International's main offices are in Berlin and London), while the farms that receive certification are in the 'South' (Latin America, 
Africa and Asia). The fact of this geographical disparity between the locations of those who create - and enforce - the standards and those who are subject to them has been widely criticized, because it follows the same patterns as did previous colonial relations (Gómez Tovar et al. 2005; Mutersbaugh 2002; Mutersbaugh 2005). It also has been observed that while Northern consumers may be driven by "aesthetic" interests in the tropical regions, they simultaneously constitute the livelihoods of those regions inhabitants (Dickinson and Putz 1992 in Price 1994). Poor farmers in the tropics facing a choice between economic opportunity and environmental protection will favor the former (Price 1994).

Under the logic of prioritizing ecological values, the role of scientists and policy makers - via certification courtship of Northern activists/consumers - is to educate farmers about the environmental value of the ecosystem services provided by shaded systems (Steffan-Dewenter et al. 2007). The premiums for certified products produce economic incentives that delay the conversion of shaded plantations to more profitable agricultural systems (Steffan-Dewenter et al. 2007). Steffan-Dewenter et al (2007) argue that the deployment of agricultural intensification techniques - even if these are used to minimize pressure over wild forest—is undesirable because it may lead to resources concentration in the hands of families that are already above the regional norm (SteffanDewenter et al. 2007). For Steffan-Dewenter et al. (2007), concerns about ecological services and tropical biodiversity take precedence over the local desires for economic sustainability. Certification is seen as a policy tool to slow down economic development—a political project to maintain equalitarian poverty in the tropics. 
Indeed, some authors have found that the institutional arrangements of certification efforts institutional arrangements may perpetuate unequal relationships (Mutersbaugh 2005; Mutersbaugh 2002). Certification requires that farmers set up and maintain complex management systems because the burden of proof is in their hands (Mutersbaugh 2002a). In fact, there is empirical evidence that shows that the requirements of certification systems are so complex that a medium-sized developing country firm was able to become certified only after receiving loans for US\$ 80 million; the same study shows that a farmers' association was able to become certified only with the assistance of several international NGOs and IGOs (Melo and Wolf 2007). It is unlikely that independent small farmers could fulfill certification requirements in the absence of transfers of human, social and financial capital (Melo and Wolf 2007). Certification layering - the practice of labeling a product with two or more certification labels - only increases the complexity of the management system, and leads to situations where farmers perceive that the costs of certification outweigh economic gains (Gómez Tovar et al. 2005; González and Nigh 2005; Mutersbaugh 2005; Mutersbaugh 2002). Thus, farmers opt out of alterative trade networks in times when premiums are low (Taylor, Murray, and Raynolds 2005). Finally, there is evidence that the premium for certified goods does not imply a better income for producers. For example, in a survey of farmers selling Fair Trade coffee Wilson (2010) found that all of them reported net income losses and an increasing amount of outstanding debt.

Further criticism addresses the question of who reaps the profits of niche markets. The complexity of the required environmental management system required to opt for organic and other environmental certification schemes favors the economies of scale 
available to large corporations, which have access to the human and financial capital needed for 'conversion' from conventional agriculture (Murray and Raynolds 2000). In cases where corporations do not get involved in production, corporations may opt for acquiring 'alternative' brands, which critics suggest leads to the erosion of the 'alternative' meaning (Off 2009). Also, there are concerns about a possible commoditization of fair trade — products, born out the decision of Fairtrade Labeling Organizations International (FLO) to grant certification to large plantations (Levi and Linton 2003; Jaffee 2007). Low and Davenport (2005) voiced concerns over appropriation of the fair trade brand. As certification becomes part of the mainstream, large corporations engage in the use of labels without necessarily sharing the transformative motive that was behind the ethical trade system when it was put in place (Raynolds 2009). Certification stops being a partnership between committed producers, manufacturers and consumers, to become a tool for commodity traceability (Raynolds 2009).

\section{Methods}

The narratives of chocolate: collection and analysis

From 2005 to 2009, I collected 39 chocolate bars from 27 sources/manufacturers. For comparison purposes, this represents 37.5\% of bars added from 2008 to May 2010 to the Chocolate Census ${ }^{\mathrm{TM}}$ database of the C-Spot ${ }^{\mathrm{TM}}$, a web site designed to be the "ultra consumer's guide for premium chocolate" (Mark Christian, email to author, 05/05/2010). 
Of the 39 bars, 35 were commercially available in the US at the time of collection; ${ }^{1}$ one was supplied by a chocolate reviewer [as a scanned image], and the remaining three were cocoa producers' organizations marketing bars sold or given away at a farmer's meeting in Ecuador (see Table 1). By source, my sample encompasses bars from Argentina (1), Austria (1), Ecuador (12), France (3), Germany (2), Italy (2), Switzerland (1) and the United States (US) (5). In the US, the bars in my sample are priced in the range of US\$ 0.04 to US\$ 0.15 per gram (US\$ 1.1 to US\$ 4.25 per oz). I did not include 'super premium' bars (> US\$0.7 per gram, $\sim$ US $\$ 20$ per oz) (see Table 1).

For the analysis, I selected a sub-sample with one bar from each source $(\mathrm{n}=27)$. For drafting this sub sample, first I selected bars with $70-80 \%$ of cocoa. Second, if a manufacturer produced more than one bar on this percentage, I selected bars by origin (in order: Los Ríos $>$ Guayas $>$ Manabí $>$ Esmeraldas $>$ El Oro) ${ }^{2}$, for a sub sample of 27 bars by source (see Table 1).

The full texts from each wrapper, excluding the "nutritional information" and "list of ingredients," were entered in a MS Excel worksheet. I also noted presence of certification seals (either logos or text), health statements, and contact information. While each bar shape, size and packaging ('wrapper') was clearly distinctive, all the packing has a 'front' side and a 'back' side. I recorded them separately. I entered text inside (as printed inside or in attached marketing inserts) as a different variable. I translated texts in other languages to English. For analysis, I used the translated texts. General statistics about

\footnotetext{
${ }^{1}$ Hersheys' Cacao Reserve Country of Origin line was discontinued by the end of 2008.

${ }^{2}$ The order reflects "Arriba" historical range.
} 
bars were calculated using Microsoft Excel 2002(SP3). Text processing was completed with QDA-Miner 3.2.3. Text statistics were conducted with WordStat 6.0, with an exclusion list made of articles, pronouns, prepositions, conjunctions, and brand names. For qualitative analysis, I used text from the bars and evaluated them against the framework I derived from my review of issues covering cocoa production. I contacted (by email, in English) the makers of the bars in cases where clarification was needed. In practice, the U.S.-based chocolate manufacturers answered my questions, while European chocolate makers did not.

\section{Field work}

The study was conducted on Ecuador's western lowlands, from May to December of 2009, in the provinces of Azuay, El Oro, Guayas, Los Ríos, Manabí, Santa Elena, and Santo Domingo de los Tsachilas (see Figure 1). This study gathered data from three sources: a collection of cocoa-related publications and resources collected during fieldwork, in-depth interviews with farmers and farmers' leaders in all the aforementioned provinces and an open-answer survey applied to farmers residing in the provinces of Azuay, Guayas and Los Ríos.

The first data source consists of approximately 100 brochures, reports and handbooks on the general topic of Ecuadorian cocoa collected during field work; $277 \mathrm{MB}$ ( $\sim 50$ files) available in FEDECADE’s computers up to December of 2009; $194 \mathrm{MB}$ ( 1000 files) of the Conservacion y Desarrollo (CYD) cocoa project, and of 176 documents made publicly available by CYD at the social publishing website Scribb [www.scribb.com]. 
The brochures, reports and handbooks were published by organizations involved with cocoa-development projects from 2000 to 2009. Among others, this repository contains documents published by farmer's organizations, cocoa exporters, local and international non-governmental organizations, intergovernmental organizations, government agencies and private companies. These documents range from publicity materials to documents dealing specifically with alternative trade networks. All these documents are publicly available in Ecuador, although circulation may be restricted because of limited number of copies. In addition, I was granted access to the personal archives stored in the town of Jesus Maria in the residence of FEDECADE's President, Agr. Victor Chacon Salinas. Relevant files were scanned and converted to digital files.

The digital archives of FEDECADE and CYD represents the fraction of the information produced by these two organizations that has been preserved in the face of changing technology, frequent failure of electronic equipment, and lack of backups. Finally, my collection of electronic material was complemented with online repositories, such as the judicial magazine known as "Derecho Ecuador" which makes copies of the Ecuadorian Official Registry freely available [http://www.derechoecuador.com/]. I used Atlas.Ti.6.1.1. for the sorting and processing of all digital files.

Regarding the second data source, the in-depth interviews script was designed to gather information about farmer organizations' experiences with cocoa commercialization, interactions with local and external agencies, and a general feeling about the state of the industry from farmers' perspective. The interviews were conducted in Spanish, on the basis of participant willingness and time availability. I interviewed farmers and leaders from 12 cooperatives, pre-cooperatives and associations. 
This study's third data source consists of an open-answer survey given to 160 cocoa producers from Los Ríos, Guayas, and Azuay (see Appendix 1 for the Survey instrument, Appendix 2 for the list of variables, and Appendix 3 for FIU Internal Review Board Approval). These producers were included in the records of one of two farmers' organizations working in these provinces. The first farmer organization, the "Federacion Nacional de Productores de Cacao del Ecuador" (FEDECADE) is a federation (union of associations and cooperatives) that has about 1100 members associated with 12 farmers' groups located in the provinces of Azuay, Esmeraldas, El Oro and Guayas (see Figure 1). The FEDECADE farmers hold up to three certifications (Fair Trade, Organic and Rainforest Alliance). To achieve these certifications and develop its commercialization system, from 1997 to 2008 FEDECADE received support from several international agencies through an alliance with an Ecuadorian NGO called Conservacion y Desarrollo (CYD) (Conservation and Development). However, at the time of the study FEDECADE's commercialization system was not operating, and the farmers I interviewed were selling their cocoa at the local market.

The second farmer organization, the "Asociacion de Productores Organicos de Vinces" (APOV), has approximately 240 members with farms in or in the outskirts of the town of Vinces, Province of Los Ríos (Figure 1). At the time of the study, an APOV farmer could hold two certifications (Organic and Rainforest Alliance). Contrary to FEDECADE, the APOV had not received any investment from the IGOs-NGOs conglomerate. Instead, it was created as a mutual benefit venture of cocoa farmer's, local intellectuals, Vinces' Agricultural Technology Institute of the University of Guayaquil at Vinces, an ex-NGO field agent/organic certification agent, and COFINA—a cocoa 
exporter that became involved in alternative trade markets via FEDECADE's experience. The APOV commercialization model does bypass local middlemen, but delivers cocoa to the exporter COFINA. COFINA then allocates APOV's Rainforest Alliance and Organic Certified cocoa to clients willing to pay for this crop. The APOV is favored by its symbiotic relationship with the Agricultural Technology Institute of the University of Guayaquil at Vinces. First, the APOV is a tenant of this institute - thus sidestepping the need for costly commercialization infrastructure. Second, the APOV farmers have access to a continuous stream of young agronomists — some of which receive cacao training from the APOV.

Both FEDECADE and APOV are established in areas that have been long dedicated to agriculture: APOV's Vinces was at the center of the late 1800's and early 1900's first Ecuadorian cocoa boom, and FEDECADE's farms are located in areas opened to the cultivation of cocoa and bananas in the early 1950's and 1960's.

The survey was conducted at each participant's residence in the case of FEDECADE members, and at the communal point-of-sale in the case of APOV's. I conducted the interviews in Spanish. In average, each interview took about 60-90 minutes. The survey consisted of four parts (see Appendix 1). The first, personal history, is made of questions that establish age, gender and background of the farmers in the sample. The second, land management, measures the amount of land managed, and the level of fragmentation of this area. The third, cocoa and other crop production, asks questions about the crops managed by each farmer (including questions about crop variety, yield, and age of the crops); it also includes questions about farmer's perception about the benefits and liabilities of cocoa varietals. Finally, the commercialization and 
income section, asks questions about the income generated by cocoa under different selling modalities, and asks for other economic activities that contribute to farmer's income. In addition, APOV supplied individual farmer's cocoa sales (by variety, price and amount) data from their commercialization records. All economic and transactional data is presented in US dollars (US\$), which has been the Ecuadorian legal tender since 2000. A detailed list of the variables collected can be found in Appendix 2.

Farmer's were recruited in the sample depending on their willingness to participate in the study, and on the basis of two criteria: a) de-facto management of the land, b) being included in the rolls of associations registered with FEDECADE, or membership with the APOV. The application of these two criteria yielded a sample of 100 farmers (out of 174 possible) registered with FEDECADE's Nueva Union Campesina, 6 de Julio, Camacho and La Florida Associations, and a sample of 60 farmers (out of 223 possible) belonging to the APOV.

In addition to the data gathered from the surveys and previously existing databases, I conducted in-depth interviews with farmers that had been or were currently involved with their community's cocoa commercialization team in the case of associations affiliated to FEDECADE. This information was complemented with interviews with FEDECADE and APOV representatives and staff, government and nonprofit organization officials, cocoa exporters, other farmer's organizations representatives and cocoa town-level middlemen. Both FEDECADE and APOV kindly granted the researcher access to an anonymized version of their commercialization databases, and other financial and economic information. 


\section{Survey data analysis}

A farmer's on-farm gross product is reported as the standardized Farm Gross Product in US\$ per ha year (FGP ha/year), which is the sum of income for all possible on-farm crops standardized by total farm area (see Figure 2). To estimate crop expenses for cocoa Nacional and CCN-51, I rely on the Average Management Cost by Province published in the Fine Cacao Management Cost Census ${ }^{3}$ (CORPEI 2009). Data gathered with the in-depth interviews with farmers were used to estimate management cost for other crops (i.e., bananas, passion fruit or plantains). These estimates are used to calculate a farmer's Gross Agricultural Income (GAI), and the Farm Gross Income (FGI), which is a farmer's GAI divided by the area of his or her holdings (see Figure 2).

To establish the percentage of farmers whose agricultural income sets them below poverty, I compared the GAI values with the values of the Ecuadorian national extreme poverty level and the basic income level (INEC's Canasta Familiar Vital and Canasta Familiar Basica) (INEC 2010). The INEC CFV (Canasta Familiar Vital) is set based on the survival income for a family of four; families that earn less than this amount are classified as extremely poor. The CFB, which is set at a higher level of income, sets the level below which a family of four is classified as poor. Given that GAI income data presents a yearly estimate based in the prices for October and November of 2009, I used the CFV and CFB for these months multiplied by 12 to get a comparable yearly statistic. With these caveats, the CFV level is set at a monthly income of $\$ 370.25$ for an annual

\footnotetext{
${ }^{3}$ While the Census focused in Nacional, it also includes Management Costs for CCN-51 plots.
} 
value of $\$ 4443$; the CFB level is a monthly income of $\$ 522.46$ for an annual value of \$6269 (INEC 2010).

When appropriate, general statistics (i.e., mean, median, SD) were calculated using Microsoft Excel 2002 (SP3). Linear regression and other tests were conducted using Minitab 14. Survey text processing was done using QDA-Miner 3.2.3; interview data mining and sorting was done using Atlas.Ti.6.1.1.

To establish the relationship between poverty, crop diversification and area of a farmer's holding, first I classified farmers in four groups each one set by one type of crop diversification schemes I found during field work: Nacional-only, CCN-51-only, both Nacional and CCN-51, cocoa (Nacional and CCN-51) and other crops. Second, I performed linear regression analysis to establish the relationship of gross agricultural income (GAI) as a function of the area held under that specific crop diversification scheme. Then, I used the regression equations to find the area of a holding under each diversification scheme - all other things being equal — that will generate an income that sets that farmer above CFV or CFB by the type of cropping system 


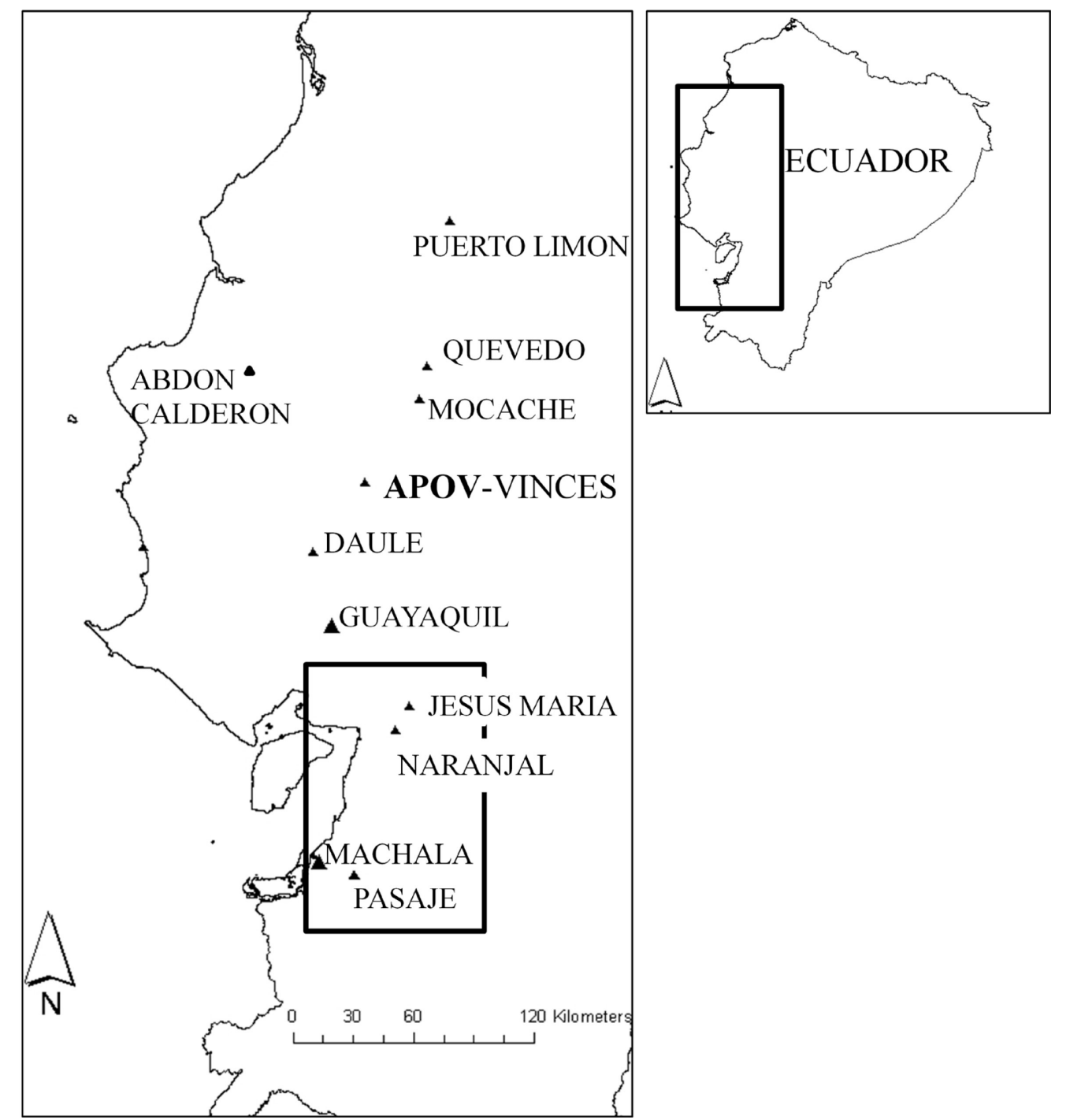

Figure 1. Area of Study. Ecuador, the Western lowlands (Costa), APOV and FEDECADE associations and cooperatives. 


$$
F G P=\frac{\sum\left[Y C_{1} \times S C_{1} \times \overline{P C_{1}}\right]+\cdots+\left[Y C_{n} \times S C_{n} \times \overline{P C_{n}}\right]}{T F S}
$$

(a) Formula to calculate standardized Farm Gross Product (FGP), where $\mathrm{YC}_{1}$ is yield for crop 1; $\mathrm{SC}_{1}$ is area for crop 1; $\mathrm{PC}_{1}$ is the reported gate price for crop 1, and TFS is the total area of the farm.

$$
F G I=\frac{\left(\sum\left[Y C_{1} \times S C_{1} \times \overline{P C_{1}}\right]+\cdots+\left[Y C_{n} \times S C_{n} \times \overline{P C_{n}}\right]\right)-\left(\sum\left[Y C_{1} \times S C_{1} \times \overline{M C_{1}}\right]+\cdots+\left[Y C_{n} \times S C_{n} \times \overline{M C_{n}}\right]\right)}{T F S}
$$

(b) Formula to calculate standardized Farm Gross Income, where $\mathrm{YC}_{1}$ is yield for crop 1; $\mathrm{SC}_{1}$ is area for crop 1; $\mathrm{PC}_{1}$ is the reported gate price for crop $1 ; \mathrm{n}$ stands for crop planted (1-4), and TFS is the total area of the farm.

Figure 3. Formulas to calculate (a) standardized Farm Gross Product (FGP in US\$ ha/year) and (b) standardized Farm Gross Income (in US\$ ha year) 
Table 1 . Chocolate bars by brand, origin, $\%$ of cocoa, and country of origin of manufacturer

Name, brand and \% cocoa

Amano Guayas 70\%

Amedei Ecuador 70\%

Ashumira Shumiral (Azuay) $\mathrm{n} / \mathrm{d} \dagger$

Askinosie San Jose del Tambo Nibble Bar 70\%

Cacaoyere Cumba (Esmeraldas) 71\%; El Eno (Amazonia)

63\%; Las Naves (Bolivar) 82\% and Puerto Quito

(Pichincha) 91\%

Caoni Esmeraldas 55\% and Los Ríos 77\%

Chocolat Bonnat Equateur 75\%

Chocolove XOXOX Ecuador 72\%

Corporacion Fortaleza del Valle Calceta (Manabí) 60\%†

Dagoba Los Ríos 68\%

Domori Cacao Arriba 70\% and Cacao Cult Ecuador 70\%

E. Guittard Quevedo (Los Ríos) 65\%

Fino de Aroma 45\%

Francois Pralus Equateur Fortissima 80\% and Equateur

Trinitario $75 \%$

Hachez Cocoa d'Arriba 77\%

Hershey's Cacao Reserve Arriba 50\%

Hoja Verde 58\%

Kallari 75\%; 85\% and Roberto's Recipe 75\%

Lindt Excellence Ecuador 75\%

Nestle Dark 60\%

Pacari Esmeraldas 60\% and Manabí 65\%

Republica del Cacao El Oro 67\%; Los Ríos 75\% and

Manabí 75\%

Salgado Grand Cru Esmeraldas 70\%

UNOCACE Floral 75\% $\uparrow$

Valrhona Alpaco Ecuador 66\%

Vintage Plantations 90\%

Zooter Labooko Single Machala (El Oro) 60\%
Country of manufacturer

USA

Italy

Ecuador

USA

Ecuador

6

France

USA

Ecuador

USA

Italy

USA

Ecuador

France

Germany

USA

Ecuador

Ecuador

Switzerland

Ecuador

“

“

Argentina

Ecuador

France

Ecuador

Austria

All bars were commercially available at the time of collection unless marked: $\uparrow$

Promotional bar; \$ Courtesy of Mark Christian (C-Spot). 


\section{REFERENCES}

Ashman, D. 2001. Strengthening North-South Partnerships for Sustainable Development. Nonprofit and Voluntary Sector Quarterly 30(1): 74-98.

Barbier, Edward B. 2000. Links between economic liberalization and rural resource degradation in the developing regions. Agricultural Economics 23: 299-310.

Barbier, Edward B. 2003. EXPLAINING AGRICULTURAL EXPANSION, RESOURCE BOOMS AND GROWTH IN LATIN AMERICA. Environment, Development and Sustainability 5(3-4): 437-458.

Barbier, Edward B. 2004. Agricultural Expansion, Resource Booms and Growth in Latin America Implications for Long-run Economic Development. World Development 32(1): $137-157$

Bentley, Jeffery W, Eric Boa, and John Stonehouse. 2004. Neighbor Trees Shade, Intercropping, and Cacao in Ecuador. Human Ecology 32(2): 241-270.

Bisseleua, D H B, A D Missoup, and S Vidal. 2009. Biodiversity conservation, ecosystem functioning, and economic incentives under cocoa agroforestry intensification. Conservation Biology 23(5): 1176-84.

Bramley, C, and J.F. Kirsten. 2007. Exploring the Economic Rationale Geographical Indicators in Agriculture. Agrekon 46(1): 69-94.

Brown, Sandy, and Christy Getz. 2008. Towards domestic fair trade? Farm labor, food localism, and the 'family scale' farm. GeoJournal 73: 11-22.

Bryant, Raymond L, and Michael K Goodman. 2004. Consuming narratives: the political ecology of 'alternative' consumption. Transactions of the Institute of British Geographers 29(3): 344-366.

Clarke, Nick, Clive Barnett, Paul Cloke, and Alice Malpass. 2007. Globalising the consumer Doing politics in an ethical register. Political Geography 26: 231-249.

Clough, Yann, Heiko Faust, and Teja Tscharntke. 2009. Cacao boom and bust: sustainability of agroforests and opportunities for biodiversity conservation. Conservation Letters 2(5): 197-205.

Cochrane, Willard W. 1958. Farm prices, Myth and Reality. 1974 ed. Westport: Greenwood Press. 
Dahlquist, R., Whelan, M., Winowiecki, L., Polidoro, B., Candela, S., Harvey, C.A., Wulfhorst, J.D., McDaniel, P.A. and N.A. Bosque-Perez. 2007. Incorporating livelihoods in biodiversity conservation: a case study of cacao agroforestry systems in Talamanca, Costa Rica. Biodiversity and Conservation 16(8): 23112333.

Donald, Paul F. 2004. Biodiversity Impacts of Some Agricultural Commodity Production Systems. Conservation Biology 18(1): 17-37.

Espinosa, José, Francisco Mite, Sergio Cedeño, Sandra Barriga, and Javier Andino. 2006. GIS-Based Site-Specific Management of Cocoa. Better Crops 90(1): 36-39.

Franzen, Margaret, and Monique Mulder Borgerhoff. 2007. Ecological, economic and social perspectives on cocoa production worldwide. Biodiversity \& Conservation 16: 3835-3849.

Gobbi, A. 2000. Is biodiversity-friendly coffee financially viable? An analysis of five different coffee production systems in western El Salvador. Ecological Economics 33: $267-281$.

González, AA, and Ronald Nigh. 2005. Smallholder participation and certification of organic farm products in Mexico. Journal of Rural Studies 21: 449-460.

Goodman, David, and E. Melanie DuPuis. 2002. Knowing food and growing food: Beyond the production-consumption debate in the sociology of agriculture. Sociologia Ruralis 42(1): 5-22.

Greenberg, Russell, Peter Bichier, and Andrea Cruz Angón. 2000. The conservation value for birds of cacao plantations with diverse planted shade in Tabasco, Mexico. Animal Conservation 3: 105-112.

Gómez Tovar, Laura, Lauren Martin, Manuel Angel Gómez Cruz, and Tad Mutersbaugh. 2005. Certified organic agriculture in Mexico: Market connections and certification practices in large and small producers. Journal of Rural Studies 21: 461-474.

Halme, M. 2001. Learning for sustainable development in tourism networks. Business Strategy and the Environment 10(2): 100-114.

Harvey, Celia, Gonzalez Villalobos, and Jorge. 2007. Agroforestry systems conserve species-rich but modified assemblages of tropical birds and bats. Biodiversity and Conservation 16(8): 2257-2292.

Hayes, DJ, SH Lence, and Andrea Stoppa. 2004. Farmer-owned brands?. Agribusiness 20(3): 269-285. 
INEC. 2010. Estadisticas Economicas-Estadisticas de Precios-IPC-Series Historicas: Canasta Familiar Vital y Canasta Familiar Basica. Quito: Instituto Nacional de Estadistica y Censos. Accesed online 09/04/2010 http://www.inec.gov.ec/web/guest/ecu_est/est_eco/ind_eco/ipc/inf_act_ind/ser_hi $\mathrm{s}$

Jaffee, Daniel. 2007. Brewing Justice: Fair Trade Coffee, sustainability and survival.. Berkeley and Los Angeles: University of California Press.

Levi, Margaret, and April Linton. 2003. Fair Trade: a cup at a time?. Politics \& Society 31(3): 407-432.

Low, William, and Eileen Davenport. 2005. Postcards from the Edge Maintaining the 'Alternative' Character of Fair Trade. Sustainable Development 13: 143-153.

Luke, TW. 2005. Neither sustainable nor development: reconsidering sustainability in development. Sustainable Development 13: 228-238.

McCarthy, J. 2004. Neoliberal nature and the nature of neoliberalism. Geoforum 35(3): 275-283.

McMichael, Philip. 2000. The power of food. Agriculture and Human Values 17: 21-33.

Melo, Cristian, and Steven Wolf. 2007. Ecocertification of Ecuadorian Bananas: Prospects for Progressive North-South Linkages. Studies in Comparative International Development (SCID) 42(3): 256-278.

Moberg, Mark. 2005. Fair trade and eastern Caribbean banana farmers: Rhetoric and reality in the anti-globalization movement. Human Organization 64(1): 4-15. http://sfaa.metapress.com/index/j8ad5ffqqktq102g.pdf.

Murray, D L, and L T Raynolds. 2000. Alternative trade in bananas: obstacles and opportunities for progressive social change in the global economy. Agriculture and Human Values 17(1): 65-74.

Mutersbaugh, Tad. 2002. The number is the beast: a political economy of organic-coffee certification and producer unionism. Environment and Planning A 34: 1165-1184.

Mutersbaugh, Tad. 2005. Fighting standards with standards harmonization, rents, and social accountability in certified agrofood networks. Environment and Planning 37: 2033-2052.

NCA. 2009. Executive summary National Confectioners Association Confectionary Industry Trend Report 2009. Chicago: National Confectioners Association Confectionary. 
Off, Carol. 2009. Bitter Chocolate: Investigating the Dark Side of the World's Most Seductive Sweet. Toronto: Random House.

Polanyi, Karl. 1941. The Great Transformation: The Political and Economic Origins of Our Time. 2nd Beacon Edition, 2001. Boston: Beacon Press.

Ponte, Stefano. 2002. The ' Latte Revolution '? Regulation, Markets and Consumption in the Global Coffee Chain. World Development 30(7): 1099-1122.

Porter, G. 1999. Trade Competition and Pollution Standards: Race to the Bottom or Stuck at the Bottom? Journal of Environment and Development 8: 133-151

Price, Marie. 1994. Ecopolitics and Environmental Nongovernmental Organizations in Latin America. Geographical Review 84(1): 42-58.

Rappole, John H. David I. King, and Jorge H. Vega Rivera. 2003. Coffee and Conservation. Conservation Biology 17(1): 334-336.

Raynolds, Laura T. 2002. Consumer/producer links in fair trade coffee networks. Sociologia Ruralis 42(2): 404-424.

Raynolds, Laura T. 2009. Mainstreaming Fair Trade Coffee: From Partnership to Traceability. World Development 37(6): 1083-1093.

Rice, Robert A. 2001. Noble goals and challenging terrain: organic and fair trade coffee movements in the global marketplace. Journal of Agricultural and Environmental Ethics: 39-66.

Schroth, G, and CA Harvey. 2007. Biodiversity conservation in cocoa production landscapes: an overview. Biodiversity and conservation 16: 2237-2244.

Seyfang, G. 2005. Shopping for sustainability: can sustainable consumption promote ecological citizenship?. Environmental Politics 14(2): 290-306.

Sonnenfeld, David A, and Arthur P.J. Mol. 2002. Globalization and the Transformation of Environmental Governance. American Behavioral Scientist 45(9): 1318-1339.

Steffan-Dewenter, Ingolf, Michael Kessler, Jan Barkmann, Merijn M Bos, Damayanti Buchori, Stefan Erasmi, Heiko Faust, et al. 2007. Tradeoffs between income, biodiversity, and ecosystem functioning during tropical rainforest conversion and agroforestry intensification. Proceedings of the National Academy of Sciences of the United States of America 104(12): 4973-4978.

Taylor, Peter Leigh, Douglas L Murray, and Laura T Raynolds. 2005. Keeping Trade Fair the Fair Trade Coffee Initiative 1. Sustainable Development 208: 199-208. 
Taylor, Peter Leigh. 2005. In the Market But Not of It: Fair Trade Coffee and Forest Stewardship Council Certification as Market-Based Social Change. World Development 33(1): 129-147.

Wilson, Bradley R. 2010. Indebted to Fair Trade? Coffee and crisis in Nicaragua. Geoforum 41(1): 84-92. 


\section{CHAPTER II.}

LIVING FROM THE FUMES OF THE PAST: ECUADORIAN COCOA AND THE

\section{BRAVE NEW WORLD OF CHOCOLATE BRANDING}

\section{Introduction and Background}

Consumers in the global North have become increasingly aware that the globalization-driven consolidation of agro-food monopolies has left them with less freedom to choose between products, exposed them to health hazards, or made them accomplices in a process of rural impoverishment (Niles and Jane 2008; McMichael 2000). It has been proposed that these trends can be reversed by engaging consumers in shopping for products that embody superior values (Golding 2008; Shreck 2005; Slater 2004). Alternative trade is said to maximize the values at both ends of the commodity chain: it is visualized as a system that rewards consumers-who receive guilt-free, valueadded goods - and producers — who receive premiums over the market price (LeClair 2002; Low and Davenport 2005). These networks bypass multinational-controlled commodity chains, therefore using market-based tools to challenge the industrialized food system (Murray and Raynolds 2000; Raynolds 2000). The global community benefits from these relationships, because alternative trade actors become stewards of non-transactional public goods such as ecosystem services (Pearce 2004; Bardhan 2006). Thus, the act of consumption becomes an act of expressing global citizenship (Seyfang 2005).

Under this narrative, environmental, geographical, or social attributes distinguish true elite products from the run-of-the-mill corporate product. Facing a cultural phenomenon in which 'standard' has an ambiguous connotation, the manufacturers of 
specialty products - like wine, coffee or chocolate — face an increasing pressure to position their brands within the alternative discourse (Golding 2008).

Bryant and Goodman (2004) suggest that all forms of market-driven sustainability depend on the courtship of 'do-gooder' Northern activist consumers that are willing to 'support' poor — yet heroic — Southern farmers, to protect tropical—magical— rainforests, or unique agrarian landscapes. In this chapter, I analyze the effects of this trend on chocolate manufacturers branding. Chocolate's reputation is intimately linked to cocoa beans - a tropical crop with a globally significant (and somewhat ambiguous) footprint (Franzen and Mulder Borgerhoff 2007). I conduct this research through a case study of the packaging material of chocolate manufacturers who produce bars that are marketed as made of a high percent ( $>50 \%)$ of Arriba, Ecuadorian Nacional, or Ecuador's cocoa beans. My findings are that most manufacturers follow a minimalist approach towards bean-to-bar philosophy, with minimal involvement with the producer side of the commodity chain. This finding suggests that the rhetoric of alternative trade can be easily adopted by manufacturers, without signifying a radical departure from previous practices. Market forces encourage manufacturers to make ever more environmentally and socially progressive claims on their products. The chapter proceeds as follow. First, the chapter covers background information on the economic, social and environmental profile of cocoa production worldwide, and on Ecuadorian cocoa specifically. Then, I present the sample of chocolate bars, and the methods I used to evaluate these narratives. I then present my results and discuss my findings in the context of policy significance. 


\section{Issues of cocoa production}

Reversing a previous trend towards consumption of mass-produced candy bars (Byskov and Scheu, 1991), the segment of premium chocolates has been increasing. Indeed, the International Cocoa Organization (ICCO) states that "consumers have embraced dark chocolate as an affordable luxury" (ICCO, 2008). Industry analysts reported that sales of premium chocolate have grown an average of $11 \%$ per year, from US\$4.43 billion in the year of 2003 to US\$6.95 billion in the year 2007 (Thomas 2008). In their 2009 industry forecast, after noting that the market for dark chocolate grew 9\% during 2009 despite a worldwide economic recession, the experts affiliated with the U.S.based National Confectioners Association predicted that this trend will continue (NCA 2009).

There have been several factors propelling this newfound taste, but in this chapter I specifically address manufacturer's adoption of the rhetoric of "terroir" or origin, originally developed for wine. Under this rhetoric, the quality of a chocolate bar is said to come from the place where groves are located, the varietals planted, farmers' technique, as well as from the craftsmanship of the chocolate maker. Nesto (2010:133) considers that the trend is for chocolate makers to move "closer to the cacao plant." This has influenced the sourcing of cocoa. While all authors agree that wild cacao (Theobroma cacao L.) originated in the upper basin of the Amazon River and its tributaries, the process of domestication of this species has given origin to several genetically and geographically distinct varieties. Traditionally, cacao has been classified in three groups: "Criollos" from Central America; "Forasteros" from the Upper and Lower Amazon River basin and "Trinitarios" — a Trinidad hybrid of "Criollos" and "Forasteros." With one 
exception, most fine or flavor cocoa—used in fine chocolates and high quality chocolate coatings—comes from "Criollos" and "Trinitarios," while bulk cocoa—used for manufacturing cocoa butter and high volume chocolates - comes from Forastero varietals (Byskov and Scheu, 1991; ICCO, 2006). The exception is that the Nacional cacao variety from Ecuador - although classified as a "Forastero"- is a source of fine cacao.

Generally, Forastero varietals offer higher yields than the other varietals, and require less on-farm management. Also, the post-harvesting management of fine cocoa is more complex, time-consuming and expensive. Fine cocoa is scarce $(<5 \%$ of the annual world production), and comparatively expensive (see Figure 1). Ecuador's is the largest producer of fine cacao, accounting for almost half of the world production. Ecuador's Nacional varietal specific aroma - the Arriba flavor - is said to have premiums of U.S. \$400-\$800 per metric tonne (Byskov and Scheu, 1991; Griffith, 2001) (ICCO, 2006, 2008).

The condition of scarcity and premium price of fine cocoa- a liability for massmarket candy — is a selling point for dark chocolate. Dark chocolate marketing material is rich in statements about varietals, place and the particular conditions that are linked to a special flavor. In this, the industry follows the pattern marked in wines, in which premium quality is a product of values added by the intersection of geographically distinctive physical (i.e., soil and climate) and biological (i.e., variety) factors, specific agricultural practices, and traditional know-how (Hayes et al. 2005).

In chocolate, the use of fine cocoa has reached a new level with the crafting of single varietal / single origin bars, instead of the far more common practice of blending cocoa from different varietals and sources to achieve a brand's taste. Single origin bars 
offer an opportunity to capitalize on the difficulties of sourcing fine cocoa beans, transforming the problem of controlling beans origin and quality on the defining characteristic of a unique brand. Manufacturers have adopted the expression "from bean to bar," which was used to describe the process of transforming beans into chocolate, to reflect an improved control over the source of the beans. In addition, this same expression suggests that it is possible for a consumer to trace the beans on a chocolate bar to the place of production. Finally, some manufacturers extend the bean-to-bar narrative linkages to include information about the cocoa farmers and the conditions under which the production was done (Grimes 2009)

However, from a brand perspective moving "closer to the farm" is not without risks (Nesto 2010:133). Cocoa production has social, economic and environmental footprints, which are intrinsically linked to the nature of the crop. As chocolate makers get close to the source of the beans, they get closer to the impacts. A brand's reputation still depends on traditionally-controlled manufacturing quality, but it can also be affected by events outside of the manufacturing process. Well-known brands - such as Nestle or Barry Callebaut — suffered from bad-reputation 'spill-over' from documentaries such as child-labor-denouncing Mistrati and Romano's The Dark Side of Chocolate (2010), or the Fairtrade-busting BBC Panorama: Chocolate-The Bitter Truth (2010). Thus, chocolate makers face a dual task: to define what their brand is, while simultaneously defining what the brand is not (Golding 2008).

Contrary to many other crops, cocoa cultivation has not been mechanized, and remains labor-intensive. This benefit small farmers, which rely on family labor. However, farmers' families may prioritize work on the fields over schooling for their 
children (Nkamleu and Kielland 2006). The use of forced labor is a more disturbing result of cocoa labor requirements. Cocoa plantations' dependence on slave and indentured labor is a well documented historical fact (see Cardozo 1961; William Gervase Clarence-Smith 1993; Satre 2005). There is evidence that the use of forced labor continues. For instance, the U.S. Department of State Trafficking in Persons Report (2009) mentions that forced child and adult labor is used in the cocoa sector of Ivory Coast and Ghana, among other countries (USDS 2009). Chocolate makers have been dealing with the results of these findings, including the public outrage that accompanies them (Blowfield 2003, Berlan 2009). The largest world chocolate processors (Barry Callebaut, Cadbury, Ferrero, Hershey Foods, Kraft Foods, Mars Incorporated, and Nestle) finance the International Cocoa Initiative, a non-profit organization dedicated to "ending child and forced labor in the sector" (ICI 2010). Also, as has happened in other products such as coffee (McDonagh 2002), chocolate processors have been keen on sourcing cocoa from producers whose compliance with labor standards is verified by a third party. Finally, other manufacturers have opted-out of areas identified as prone to labor abuses.

The rediscovery of the "bitter" or "dark" side of cocoa production also spotlighted other impacts that the industry has on the economy and environment of less-developed countries. As with any tropical commodity without staple food value, cocoa production ties the welfare of farmers to the vagaries of the international markets and the fickle taste of Northern consumers (Talbot 2002). Cocoa prices, like those of other commodities, suffer from boom and bust cycles. During boom periods, with high world-market prices and relatively scarce supply, farmers often replace forest with new plantations (Clough, 
Faust, and Tscharntke, 2009). Enticed by high prices, farmers also plant cocoa in land that was used for food production, which may restrict food availability in the near future (Belsky and Siebert 2003). When the production of these new plantings comes into the market, overabundance of supply leads to drastic falls of word market prices. Lost revenues jeopardize the livelihood of individual farmers and present a threat for regional stability (see Figure 2). Indeed, Manzo (2005) suggests that the aforementioned harsh labor conditions in Western Africa were born out of farmers need for extreme costcutting measures in response to the fall of word-market prices ${ }^{4}$.

The expansion of the agrarian frontier that accompanies boom periods also generates pressures on local ecosystems. Several studies have found that cacao groves, even under low impact management, are not as diverse as the forest they replaced (Andersson and Gradstein, 2005; Bentley, Boa, and Stonehouse, 2004; Faria and Baumgarten, 2007; Greenberg, Bichier, and Cruz Angón, 2000; Haro-Carrion, Lozada, Navarrete, and de Koning, 2009; Rice and Greenberg, 2000). When the prices collapse, farmers are pressured to either intensify production, or shift to other uses of land (Clough, Faust, and Tscharntke 2009). Intensely managed cocoa groves have higher yields than shaded groves. However, the environmental impact of intensely managed groves is higher, as they have no shade and require more inputs than less intensively managed ones (Franzen and Mulder Borgerhoff 2007). Provision of ancillary ecosystem services is diminished (Bisseleua, Missoup, and Vidal 2009). Finally, the loss of shaded plantations

${ }^{4}$ Cocoa prices reached a historical low by the year 2000. Manzo (2005) indicates that, for that period, gate prices were below the cost of production of even the most efficient farmer. 
implies loss of the species' genetic variety, given that researchers have found that cocoa farms function as in-situ reservoirs of rare, endangered or 'heirloom' varieties (Deheuvels et al. 2004; Whitkus et al. 1998; Bentley, Boa, and Stonehouse 2004).

Interestingly, the development of certification systems and geographical marketing offers an opportunity for certain chocolate manufacturer to reap benefits out of addressing sustainability issues in cocoa production. For example, the market for organic chocolate products has grown 15\% per year according to some estimates (Pay 2009). Shade-grown, low input cocoa groves are usually organic by default, given that farmers cannot afford agrochemical inputs (Barrett et al. 2002). The rise of the consumption of organic products offers an opportunity to use this 'organic by default' management system to enter an attractive market niche. It has also been reported that the market for Fair-Trade products in the US has grown about 83\% annually since 2002 (Pay 2009). Thus Fair-Trade certified products deliver marketing benefits to manufacturers while addressing social sustainability issues at the producers' level. Other certification systems generate value out of agronomic particularities of cocoa production. For instance, protecting the environmental ancillary services provided by low intensity-shadedplantations was a driver for the involvement of the environmentally-centered certification offered by Rainforest Alliance. Finally, two or more certification systems can be simultaneously held by a bar aiming to capture potential consumers by creating a smorgasbord of meanings and concepts that cater to the sensitivity of a wider audience (Browne et al. 2000).

However, it has been observed that the narratives that declare that product has superior ethical (and environmental) values can in fact hide the distance between 
producers and consumers (Hollander 2003). Hollander (2003) also suggest that the deployment of ethical and geographical marketing creates premiums that are disconnected from the commodity production costs.

\section{Ecuador's cocoa: Living from the fumes of the past?}

Ecuador's reputation for fine cocoa was established back in the 19th century, when the country was the world's largest cocoa producer, accounting for 20 to $50 \%$ of world's production during the 19th century (Griffith 2004). Cocoa was planted in large estates in the Ecuadorian coastal area, mainly in the sub basin of the Guayas River. A geographer of the time describes this region as "one great paradise," with "plantation after plantation" and "hacienda after hacienda" extending along the river banks (Wolf 1893). However, the production of cocoa at the time was not uniform. Van Hall (1914) recognized two commercial varieties, a Criollo-type known as Ecuador or Esmeraldas Cundeamor and the Forastero-type Ecuador Amelonado. The first variety, the highly appreciated Ecuador or Esmeraldas Cundeamor, was commercialized under the name of “cacao de Esmeraldas" or "Esmeraldas" (van Hall 1914; Knapp 1920; Whymper 1921; Lery 1954). The production of this cocoa was restricted to the province of Esmeraldas (in Northwest Ecuador). Van Hall said that it had a close resemblance to Venezuelan Criollos cacaos (Van Hall, 1914; Lery 1954). The second of Van Hall's varieties, classified as Ecuador's Amelonado (or "cacao Nacional"), was found in four commercial types named after the regions of production. Then and now, the Ecuadorian Amelonado cocoa is well-regarded by the industry, because of its "strong flavor and scented aroma," being an exception to the general rule that 'fine' cacaos come exclusively from Criollotypes (Knapp 1920). Indeed, it is the only Forastero that qualifies as fine cacao. The first 
commercial type, the famous Arriba, came from the upper basin of the Guayas River and its tributaries (arriba means "up," as in "up-the-river"). The Arriba region roughly encompasses the parts of the Province of Guayas, the Province of Los Ríos and a small fraction of the Province of Bolívar (Wolf 1893; Parsons 1957; Crespo 1986). Outside of this region, fine cocoa was also produced in the other areas, and traded under other 'market' names. The first among these Nacionales was produced in the wet part of the Province of Manabí, near the towns of Chone and Calceta. This cocoa was commercially known as "Bahia," "Caraques," or "Manabí" (Lery 1954; van Hall 1914; Whymper $1921)^{5}$. Cocoa was also produced in the region of "Abajo" (down the river) (Parsons 1957), in Southern part of Guayas and the coastal area of Azuay and Cañar. The cocoa of this region was known as "Balao," for the name of the area where a still existing large plantation is located (Van Hall 1914). Finally, cocoa was also produced in the Province of El Oro. This last cocoa type was known as "cacao Machala." (Parsons, 1957; Van Hall 1914; Knapp 1920; Whymper 1921). Finally, there is also a late 19th century account of large wild cacao plantations along the Napo River (Eastern Ecuador, in the Upper Amazon Basin) which was deemed "scarcely inferior to what is known in the market as arriba" (Tyler 1894), and two early 20th century reports of wild cacao stands growing on the banks of the River Bobonaza (Province of Napo) (Holloway 1932) and Rio Zamora (Province of Zamora) (Hermessen 1917), but there are no records that suggest that cocoa from this region was exported at the time.

\footnotetext{
${ }^{5}$ Van Hall mentions that calling this cacao "Bahia" is "inconvenient" because this is also the name of the cacao produced in the Brazilian state of Bahia.
} 
Ecuador's cocoa industry was the main source of income for the country, accounting for $71 \%$ of the country exports by 1920 (Henderson 1997). However, by the 1930s, Ecuador's cocoa exporting industry had collapsed. Ecuador's plantations were decimated by the attack of two previously unknown fungal plant pathogens, Crinipellis perniciosa (known as "witch's broom," or "escoba de bruja"), and Moniliophthora roreri (known as frosty-pod disease, or "monilla") (Griffith, 2004; Parsons, 1957) ${ }^{6}$. The severity of the attack of these diseases cannot be overstated. Current reports indicate that C. perniciosa can cause yields to drop by $90 \%$; even more serious is the attack of $M$. roreri which can infest and destroy up to $100 \%$ of the pods (Hebbar 2007; Griffith 2004; Phillips-Mora and Wilkinson 2007).

The Nacional genotype, which recent genetic studies suggest were a highly homogenous population, proved especially susceptible to the attack of these diseases (Griffith 2004). Thus, by 1930 Ecuador's production (14,000 tons) was one-third of what was produced in the year of 1920 (39,790 tons) (Lery 1954; Henderson 1997). Ecuador's share of the world production fell from $11.7 \%$ in 1920 to $2.7 \%$ by 1930 (Lery 1954 ; Henderson 1997), and the product accounted for just less than one-fifth of the country's exports (Pineo 2007).

The 1920's collapse of the cocoa export industry ${ }^{7}$ gave origin to three lingering trends whose effects have shaped contemporary cocoa production in Ecuador. First, Ecuadorian cocoa production survived as a small farmer's cash crop, in part because they

\footnotetext{
${ }^{6}$ Griffith (2004) indicates that the first report of Crinipellis perniciosa in Ecuador is dated from 1921 and that the first report for Moniliophthora roreri dates from 1917.

${ }^{7}$ It also caused the collapse of Ecuador's economy, and lead to a period of civil unrest.
} 
did not have access to the resources needed to convert their holdings to more profitable production systems, and in part because shade-grown cocoa tolerates adverse weather factors, and thrives in landscapes and soils where other crops do not (Bentley, Boa, and Stonehouse, 2004). Second, foreign disease-resistant cocoa varieties were introduced in attempts to revitalize the industry (Lerceteau et al. 1997) ${ }^{8}$. Because these introductions did not have the Arriba flavor, naturally-occurring hybridization led to a progressive erosion of the Arriba/Nacional genotype up to the point where it has been reported that "the Arriba flavor is hardly found" (Petithuguenin and Roche 1995 in Deheuvels et al. 2004: 23). Thirdly, as early as the 1930 's, scientists were encouraging changes in plantations management to combat diseases (Bentley, Boa, and Stonehouse 2004). Given that both C. perniciosa and M. roreri infestations are more severe under dense canopies, farmers were encouraged to regulate the shade covering their groves (Griffith 2004). The practice of growing cocoa under shade has been progressively abandoned. Indeed, some of the new varieties are not planted under shade at all (Espinosa et al. 2006; Bentley, Boa, and Stonehouse 2004). In fact, CCN-51 ${ }^{9}$, a full-sun, high-yield, non aromatic variety accounts for $48 \%$ of the plantings made within the last 5 years according to Bentley, Boa, and Stonehouse (2004). The CCN-51 variety yields almost 4 times that of Nacional

\footnotetext{
${ }^{8}$ However, there are reports of introduction of foreign Trinitarios (locally known as Venezolanos) as early 1890 (Van Hall, 1914).

${ }^{9}$ During field work in Ecuador, the first author was able to find a copy from a paper by this variety creator, Homero U. Castro. Castro describes CCN 51 as a cross of F1 of IMC-67 x ICS-95 by O-1, where O-1 was a cacao ascension collected by himself in a trip to Ecuador's Valle de los Canelos (Castro 1981). According to this paper, CCN stands for Coleccion Castro Naranjal and 51 stands for the number or the cross that gave origin to this variety.
} 
(Espinosa et al. 2006) and is resistant to fungal diseases, but lacks the Arriba flavor (Griffith 2004). The consequence of economic marginalization, genetic erosion and changes in management practices have led to a progressive loss of Ecuadorian cocoa quality. By 2005, the International Cacao Organization downgraded the country's cocoa rating from $100 \%$ fine flavor cocoa to $75 \%\left(\right.$ ICCO, 2006) ${ }^{10}$.

The ICCO downgrade spurred responses from the government sector. At the time, there were three main policies established to address the decline of Ecuadorian cocoa. First, the Ministry of Agriculture, Cattle Ranching, Aquaculture and Fishing (Ministerio de Agricultura, Ganadería, Acuacultura y Pesca, MAGAP) published Accord 070 of July 22 of 2005, declaring cocoa as a Ecuador's National Symbol. This declaration cleared the way for further actions. The following week the MAGAP published Accord 060 of July 27 of 2005, in which it bans shipments made of a mix of Nacional and CCN-51 beans. Second, in 2006 the Ecuadorian Institute for Statistics and Standardization published the fourth revision of the Cocoa Beans Technical Norm (NTE INEN 176:2006) which created the legal framework to separate traditional (Nacional) and non-traditional (hybrid/CCN-51) varieties, and price them differently. Third, the Institute of Ecuadorian Intellectual Property (Instituto Ecuatoriano de Propiedad Intelectual, IEPI), with the support of a heterogeneous alliance of cocoa exporters, producers' organizations, NGOs, IGOs and government agencies, published and approved the creation of the "Arriba" Protected Denomination of Origin (Arriba PDO). In this document, the use of the "Arriba" label is restricted to Ecuador's cocoa beans of the Nacional variety.

${ }^{10}$ Before this ruling, all of the cocoa beans from Ecuador were rated as "fine." 
For chocolate makers, Arriba offers a unique opportunity for showcase their brand. First, Arriba has a taste that-in words of the chocolate manufacturer Shawn Askinosie- "even people unfamiliar with dark chocolate are able to appreciate." Second, Arriba is a historically acknowledged variety—a must-have in 'single-origin' line-with a rich history of quality to back it up. Third, Ecuador's cocoa is the hands of small farmers, but there have not been linkages between Ecuador's cocoa production and child labor exploitation as has been the case in other source countries ${ }^{11}$. This gives Ecuador and advantage with chocolate makers who are wary of being criticized on social justice grounds. Fourth, country-wide loss of shaded fine cocoa plantations can be translated into a narrative in which chocolate consumption is tied to protection of these biodiversityrich, socially-important agro-ecosystems. Fifth, the Arriba PDO definition was designed to cover all Nacional cocoa produced in Ecuador. Legally, any manufacturer can use the Arriba label as long as the beans used on the bar come from Ecuador, and are of the Nacional variety meaning that the beans do not need to come from the Arriba region proper. International trends favoring dark chocolate, Ecuador's reputation for fine cocoa quality, and a favorable regulation created the conditions for a boom of products labeled "Arriba." Indeed, the availability of single-origin "Arriba" bars have greatly increased from one bar ${ }^{12}$ in 1997 to more than 139 bars by 2010, according to the chocolate expert Mark Christian (Mark Christian, phone interview with author, 03/20/2010). Evidently, the rapid growth of this market segment suggests that chocolate manufacturers are

\footnotetext{
${ }^{11}$ In Ecuador, children labor is used in the banana and cut flowers industries.

${ }^{12}$ The U.S.-based Vintage Plantations Chocolate claims that their 1997 Plantations bar was the first single-origin Arriba bar (Vintage Plantations 2010).
} 
interested in capitalizing on the marketing value of Arriba cocoa. This rapid growth also suggests a market niche with relatively low barriers to entry. I propose that a study of products designed to fit into this market-niche provides a unique opportunity to assess the effects of the adoption of the alternative trade rhetoric in chocolate products specifically, and in consumer's food goods in general. I conduct this study thorough the analysis of the use of language on packing material. This material reflects manufacturers' responses to what they perceive to be their consumer's most pressing concerns. I use the on-barnarratives to trace the bars to their putative origins. I am also interested in getting glimpses of the on-field application of this rhetoric, and assess the effect of the adoption of these concerns in changing or modifying manufacturers' practices.

\section{The bars: collecting chocolate}

From 2005 to 2009, I collected 39 chocolate bars from 27 sources/manufacturers. For comparison purposes, this represents 37.5\% of bars added from 2008 to May 2010 to the Chocolate Census ${ }^{\mathrm{TM}}$ database of the C-Spot ${ }^{\mathrm{TM}}$, a web site designed to be the "ultra consumer's guide for premium chocolate" (Mark Christian, email to author, 05/05/2010). Of the 39 bars, 35 were commercially available in the US at the time of collection; ${ }^{13}$ one was supplied by a chocolate reviewer [as a scanned image], and the remaining three were cocoa producers' organizations marketing bars sold or given away at a farmer's meeting in Ecuador (see Table 1). For the analysis, I selected a sub-sample with one bar from each source $(n=27)$. For drafting this sub sample, first I selected bars with $70-80 \%$ of cocoa. Second, if a manufacturer produced more than one bar on this percentage, I selected bars

\footnotetext{
${ }^{13}$ Hersheys' Cacao Reserve Country of Origin line was discontinued by the end of 2008.
} 
by origin (in order: Los Ríos $>$ Guayas $>$ Manabí $>$ Esmeraldas $>$ El Oro) ${ }^{14}$, for a sub sample of 27 bars by source.

The full texts from each wrapper, excluding the "nutritional information" and "list of ingredients," were entered in a MS Excel worksheet. I also noted presence of certification seals (either logos or text), health statements, and contact information. While each bar shape, size and packaging ('wrapper') was clearly distinctive, all the packing has a 'front' side and a 'back' side. I recorded them separately. I entered text inside (as printed inside or in attached marketing inserts) as a different variable. I translated texts in other languages to English. For analysis, I used the translated texts. General statistics about bars were calculated using Microsoft Excel 2002(SP3). Text processing was completed with QDA-Miner 3.2.3. Text statistics were conducted with WordStat 6.0, with an exclusion list made of articles, pronouns, prepositions, conjunctions, and brand names. For qualitative analysis, I used text from the bars and evaluated them against the framework I derived from my review of issues covering cocoa production. I contacted (by email, in English) the makers of the bars in cases where clarification was needed. In practice, the U.S.-based chocolate manufacturers answered my questions, while European chocolate makers did not.

\section{Cocoa from Ecuador, chocolate from all over the world}

By source, my sample encompasses bars from Argentina (1), Austria (1), Ecuador (12), France (3), Germany (2), Italy (2), Switzerland (1) and the United States (US) (5). In the US, the bars in my sample are priced in the range of US\$ 0.04 to US\$ 0.15 per

\footnotetext{
${ }^{14}$ The order reflects "Arriba" historical range.
} 
gram (US\$ 1.1 to US\$ 4.25 per oz). I did not include 'super premium' bars ( $>$ US\$0.7 per gram, $\sim$ US\$20 per oz). The average cocoa content of the bars was $70 \%( \pm 7 \%)$, with the "Fino de Aroma" bar having the lower percentage of cocoa (45\%), and Cacaoyere's Puerto Quito having the maximum (91\%). Bar codes were present on 35 bars, with the notable exception of the Fino de Aroma and Kallari's Roberto's Recipe bars made by the Ecuadorian manufacturer El Salinerito, and the expected absence of coding on the three marketing bars from cocoa producers' organizations ${ }^{15}$.

\section{On-bar narratives: addressing issues in cocoa production}

Analysis of the narratives by source shows that the most commonly used nongeographical (NG) product descriptor is "dark chocolate," with all the manufacturers using it (or its equivalent in other languages). Other NG quality qualifiers (fine, extra, premium and unique) were used in $33 \%$ of the cases. A graphical representation of the use of terms in the wrappers is found on Figure 3. In this figure, the size of the font is proportional to the number of cases in which the word was found $(n=27)$. Other than the Ashumira Bitter Chocolate Bar from Agricola Shumiral, the percentage of cocoa in the bar was printed on the front side of the packing of all the products. In all cases, this percentage was printed in a contrasting, bold and enlarged font.

\section{Single origin, varietals, and craftsmanship}

I found a wide variation on the geographical definition of "single origin." In my sample by source, $48 \%$ of the manufacturers 'single origin' encompass all of Ecuador and

\footnotetext{
${ }^{15}$ The presence of bar codes indicate that manufacturers expect to sell the bars at the retail-level - giving that most supermarkets use these bars for price coding. The absence of bar code indicates that the bar is to be sold informally - in fairs, in small manufacturerowned shops, or used for marketing purposes.
} 
$48 \%$ of them define origin in terms of a fraction of the Ecuadorian territory (see Table 2). The Hachez d'Arriba Classic constitutes a notable exemption, given that the manufacturer only specifies that they use "premium cocoa beans from South America" (Hachez, n/d). $48 \%$ of makers describe the varietal used on their bars as Arriba ( "Ariba" sic Chocolove, n/d); $11 \%$ use "Arriba Nacional;" $11 \%$ use Nacional; $22 \%$ do not declare what variety is used on the bar; $7 \%$ describe the variety used on their bars as a rare Forastero but either do not specify if Arriba is used (E. Guitard n/d), or declare that they use a variety other than Arriba (Salgado n/d); finally, 1\% declare that they use a Trinitario bean from Ecuador (Pralus n/d).

Some manufacturers emphasize the role of their company in rescuing the Arriba varietal. For example, Dagoba's label addresses the historical decline of Arriba production, "Ecuador's once mighty Arriba Nacional is now on the verge of extinction" (Dagoba, $\mathrm{n} / \mathrm{d}$ ), and suggests that the partnership of the company with some "dedicated" farmers is necessary to rescue it. Kallari's narrative suggests that the decline on Nacional production was caused because it was "over planted in factory farms," which led to attack of diseases and loss of most of the Nacional genotype. However, the Kallari label explains that Nacional cocoa "survived and flourished in the Napo region, where it was protected by traditional cultivation technique[s]" (Kallari, n/d).

\section{Who is behind fine chocolate: farmers or manufacturers?}

Overall, $52 \%$ of the manufacturers in my sample acknowledge the role of farmers (producers) in protecting, selecting and cultivating cocoa varietals. Manufacturers also mention that these farmers follow traditional management practices, generally described as raising cocoa under the shade of other trees (i.e., [the farmers] "cultivated the cocoa in 
the traditional way, amid shade trees, bananas and a variety of other plants" (Zooter, n/d). Other statements hint at connections but lack specifics. For example, the Amedei label $(\mathrm{n} / \mathrm{d})$ suggests that making chocolate involves "forming relationships of friendship, respect, and partnership with the people who live where cocoa grows, keepers of ancient knowledge," but further details are lacking.

Amedei stands in contrast with the narrative of two other bars, Askinosie San Jose del Tambo and Kallari's Single Source. Askinosie's take on the 'bean to bar' premise goes to the point of personalizing their San Jose del Tambo Nibble Bar with the portrait of Vitaliano Saravia, an Ecuadorian farmer and cocoa growers' leader who was "really involved in introducing Shawn [Askinosie] to San Jose del Tambo [village] and who was involved in the entire project, including the contribution of beans" (Shawn Askinosie, phone interview with author, 04/21/2010). Askinosie's commitment is stated on the back of the bar: "the farmer on the front of this package helped gather and ferment the cocoa beans for the bar inside" (Askinosie $\mathrm{n} / \mathrm{d}$ ). The level of involvement of this company with the farmers leads to improved traceability, a point made clear with the statement that "working directly and personally with this man [Vitaliano Saravia] and other farmers-instead of brokers-allows me to help them improve the quality of their beans and allows you to know exactly where your chocolate comes from" (Askinosie, n/d). While Kallari's bar lacks this personal approach, in the text of the bar it specifies that it is owned by the farmers, who harvest and market their own bars. Kallari's text informs the reader that its beans come from 850 Kichwa families in the Napo Region of the Ecuadorian Amazon, and the particular taste of the bar is owed to farmers harvesting "endemic varieties that are available only on these small farms" (Kallari's n/d). Kallari 
also takes pride out of being a 'farmer owned' chocolate company (Kallari n/d). Kallari's bar and the three cocoa grower's associations bars (Ashumiral, UNOCACE and Fortaleza del Valle) also share the commonality in that the role of farmers, varietals and management practices are emphasized while 'manufacturing craftsmanship' is ignored. The emphasis on the local is understandable given that these four groups hire other companies to produce their bars.

I found that the making of a single origin bar is not necessarily straightforward. It may include steps done by companies other than the brand name. For example, in the insert of the Chocolove Chocolatour Ecuador Bar, the narrator (whom I assume is the manufacturer) comments on travel to Ecuador. The reader learns about the narrator's visits to cocoa farms, where this person saw "cocoa growing almost wild, intercropped among the hardwood and fruit trees" (Chocolatour n/d). The narrator also visited "the facilities where cocoa is fermented and cured and then ventured off into the forest," and tasted cocoa beans [sic] on the wild (Chocolatour $\mathrm{n} / \mathrm{d}$ ). The bar packaging also shows indicators that suggest uniqueness and traceability, such as an "Limited production counter," "Lot number," and other features that suggests that the manufacturers were able to track the cocoa from the farms (that they visited on their trip) to their production facility in the USA. However, the manufacturer also mentions that Chocolove is "Made in Boulder, $\mathrm{CO}$ with Belgian chocolate" (Chocolatour n/d). The process of making this bar is less straightforward than what its rhetoric suggests. In Chocolove's manufacturing process, the beans from Ecuador (or any other origin) are transported to Belgium, processed into chocolate blocks, and transported to the USA for repacking and selling. 
On the rest of the bars, manufacturer's traditional craftsmanship is invariably presented as a critical factor to achieve premium quality. For example, in Amano's Guayas, the on-bar narrative explains that cocoa's floral aroma ${ }^{16}$ is released only after the beans are "hand roasted" and ground using an "antique stone grinder." By using these methods the company claims that it is "reviving the art of making chocolate from the bean" (Amano, $\mathrm{n} / \mathrm{d})$.

The emphasis on craftsmanship is the strongest on the $48 \%$ of bars in which local factors (farmers and varietals) are not spotlighted. On these bars, manufacturers are said to play the key role on defining the quality of final product. However, they have a passive role in bean sourcing: they receive, select, and process the beans without the involvement described in the narratives of the previous group. A common claim is that manufacturers' expertise is what allows them to select premium beans from abroad. For example, in the narrative of the Bonnat Chocolat Equateur, it is said that their Maitre Chocolatier Stephane Bonnat plays a key role by selecting premium beans from the unroasted beans that arrive at his factory in Voiron (France) (Bonnat, $\mathrm{n} / \mathrm{d}$ ). The Swiss firm Lindt also remarks on the importance of selecting beans for achieving premium quality. The emphasis on manufacturing knowledge is the strongest suit of Hachez d'Arriba narrative. For Hachez, the quality of their bars is given by processing, following a 100 year-old "single recipe" that requires of a long processing time, expressed as "conching of 72 hours." In chocolate production, "conching" is a process that contributes to flavor development. Conching also delivers chocolate with an uniform taste, thus helping

\footnotetext{
${ }^{16}$ Arriba is known by its floral aroma (described as hints of orange blossoms).
} 
manufacturers to account for variability in their supply of cocoa beans. The use of extralong conching times produces chocolate with a basic taste. Hachez is the only brand in my sample that uses conching to signify quality (Hachez, $\mathrm{n} / \mathrm{d}$ ). The Hachez bar is also unique in that it does not state which variety is used on the bar (although it uses "d'Arriba" on the brand name), and its source of origin for the cocoa is "South America" (Hachez, $\mathrm{n} / \mathrm{d})$

\section{Ethical and environmental sourcing: small farmers and shade-grown cocoa}

Social and environmental aspects form part of the narratives of $70 \%$ of the narratives by source. Of these, both social and environmental issues are covered on $37 \%$; exclusively environmental issues are covered on $16 \%$, and exclusively social issues on $47 \%$ of them. However, only $46 \%$ of the bars are certified under Organic, Fair-trade, and/or Rainforest Alliance certification schemes. Of the certified bars, organic is the most frequent certification (50\%), followed by Rainforest Alliance (16\%), and Fair-Trade (7.4\%). I found that $16 \%$ of the bars exhibited two certification labels, with two possible combinations: Rainforest Alliance/ Organic (8\%), and Fair-Trade / Organic (8\%).

As a whole, manufacturers weigh economic, environmental and social issues similarly. For instance, Kallari's narrative is consistent with the bean-to-bar holistic conceptualization of the brand. In fact, it is one that exhibits both Organic and Rainforest Alliance certifications. Also, the narrative of this brand is a text-book definition of sustainable development, by stating that "the profits" from the sales of the bars return to the cooperative to support "sustainable development, health, and education programs while helping to preserve one of Earth's most important climate-protecting, rain forest ecosystems" (Kallari n/d). 
In another example, the narrative on the Ecuadoriana de Chocolates' Cacaoyere bar confronts environmental, social and economic issues upfront. It informs the reader that the cocoa comes from shaded cocoa groves owned by small farmers (with holdings of 1 to 15 hectares), "in harmony with fruit and timber trees and tropical woodlands" (Cacaoyere, $\mathrm{n} / \mathrm{d}$ ). The narrative then reports that "under normal circumstances, these farmers' yearly incomes are from US\$ 700 to US\$ 1200 (about US\$60-100 per month), which "is not enough to send their children to school, or to pay for health care" (Cacaoyere $\mathrm{n} / \mathrm{d})^{17}$. Then, it reports that through Cacaoyere these farmers receive a better price for their cocoa, " $45 \%$ higher than the local price" (Cacaoyere n/d). It also reports that Cacaoyere collaborates with inter governmental and non- governmental institutions (the German GTZ and the US financed ACDI VOCA are mentioned). Cacaoyere's narrative suggests that, with the help of the company and these partnerships, the cooperatives should be able to reach environmental and economic sustainability. The narrative of the Hoja Verde bar indicates that they source beans exclusively from shaded plantations, "thereby supporting a balanced natural habitat-ensuring the well-being of local communities who live in this fragile and important ecosystem" (Hoja Verde n/d). It also links consumption of a Fair-Trade certified goods to economic, social and environmental goals: "by choosing this Fair Trade certified product, you are directly supporting a better life for farming families through fair prices, direct trade, community development, and environmental stewardship" (Hoja Verde, n/d).

\footnotetext{
${ }^{17}$ The reported monthly income of these farmers, of US\$100, is a quarter of Ecuador's poverty level monthly minimum income (US\$385 per month for a family of five) (data for April 2010, INEC 2010m). The income that the farmers get from Cacaoyere, $45 \%$ higher for about $\sim$ US $\$ 145$ per month, still is a fraction of what is need to feed a family.
} 
Finally, other companies gave more emphasis to the socio-economic issues. For example, Askinosie "A Stake in the Outcome" statement-which in practice means that the company shares $10 \%$ of its profits with the farmers who produced the beans (Shawn Askinosie, phone interview with author, 04/21/2010.) - emphasize fairness in trade outside of the Fair-Trade labeling system. Kallari declares that as a farmer owned brand it transfers all of the chocolate profits back to the communities (Kallari, n/d)

\section{Single-origin on the cheap}

I found two different views of single-origin, with half of the manufacturers (48\%) opting for a country-wide definition of single origin, and the other half opting for a single-origin which is a fraction of Ecuador's territory. My results suggest that there is an inverse correlation between the area of the putative source of cocoa beans and the depth of the relationship between manufacturers and farmers as stated in the bar's narrative. Indeed, manufacturers that specifically name a farmer, farmer's group or farmer's organization as the source of their cocoa are more likely to have well defined geographical sourcing. These manufacturers are also more likely to emphasize the contribution of nature (place and variety) and culture (practice and knowledge) to the quality of the final product. On the other hand, continental or country-wide sourcing is linked to claims about manufacturers' expertise and craftsmanship, paying token attention to the farmers on the ground.

My findings also suggest that the presence of Fair-Trade or Rainforest Alliance certification on the bars increases the traceability of the product. Both Rainforest Alliance and Fair-Trade publish an online accessible database with the name of the certified producers by country and product, therefore limiting the scope of a search to a few well- 
defined locations. In the case of far more common organic certified products, the process of tracing the beans to the point of origin using packing material data is challenging. A unified organic certification database is lacking, so information about certified producers is dispersed among several certifying companies (three in my sample: Naturland, CERES and $\mathrm{BCS}$ OKO). However, the sole presence of these certification seals does not supply ample evidence about the sourcing of cocoa. Certification acts as a barrier to entry at the producer's level (limiting the number of cocoa suppliers for a particular bar), but manufacturers can effectively source cocoa from any certified producer.

Overall, my results suggest that most chocolate makers are opting for a countrywide definition of origin that does not allow for tracing the bars to the cocoa-farmingcommunity where the beans were raised. In my sample of 27 bars by source, only 4 commercially available bars and the 3 producer's organizations bars supply enough detail to trace the cocoa beans to the community of origin, although the narratives of the 23 out of 27 bars in this sub sample address the role of farmers in sourcing the cocoa.

On the other hand, the experience of manufacturers that are engaged in close relationships with producer's groups suggest that establishing these relationships is challenging. Shawn Askinosie from Askinosie Chocolates argues that this is because "it involves farmers meeting [for the first time] a chocolate maker [and chocolate makers meeting farmers], without middlemen. It is difficult because it is new" (Shawn Askinosie, interview with author, 04/21/2010). Pierrick Chouard, from Vintage Chocolates, argues that the lack of reliability of some of their local [Ecuador] partners has forced this company to change sourcing three times over the last 13 years. Chouard also indicated that developing [Vintage's] group of 17 Los Ríos-based farmers/suppliers took this 
company most of the last 9 years, and demanded the expenditure of considerable human and financial capital. Chouard argues that developing a true bean-to-bar product requires significant investments and a high level of compromise. Bean-to-bar requires that a manufacturer bypass the entrenched conventional trading system, therefore creating an alternative commodity chain from the ground level (Pierrick Chouard, phone interview with author, April 2010). The magnitude of the effort behind developing links is daunting. For example, Clark Goble from Amano Chocolates mentioned that there is an international competition for the best quality beans. In his words, "sometimes everyone wants the same beans" (Goble, email to author, 2010). Relationships with cocoa producers are not straightforward: there is competitive demand for high quality cocoa and farmers and exporters sell to the highest bidder. This company, which works with small farmers as well as large plantations, sometimes has to "work with [a] middleman, if only to manage all the regulations of customs and handling transport" (Goble, email to the author, 04/28/2010).

It can be argued that it is disingenuous to pretend the artisan chocolate makers can effectively challenge the multinationals of the candy industry. Indeed in an email to listserve subscribers, the U.S. based non-profit Fine Chocolate Industry Association said that members of the group "are not out to change the chocolate industry- I just want to support and celebrate our small segment of it" (FCIA, email to the author, 05/12/2010). From the labels, it is evident that manufacturers are designing products to meet the demand of consumers for alternative chocolate — from the forest, high quality, safe and traceable, and fair-but the mechanisms for the sourcing of this "alternative" cocoa are not clearly stated in the labels of most products, indicating that most consumers are 
satisfied with vague references to geographical sourcing and supporting-the-farmers rhetoric. Environmental and social certifications provide a higher level of traceability, but do not necessarily signify a closer and committed relationships among producers, manufacturers and consumers.

I argue that "at-length" alternative-sourcing is a perilous approach for several reasons. First, companies that rely on country-wide or regional sourcing have low control over bean quality, making them vulnerable to irregular results. As the Askinosie case illustrates, companies that work closely with farmers - and are willing to commit time and resources to cultivate these relationships - are likely to secure access to a supply of high-quality beans. Companies that opt out of developing relationships with the producers will find themselves engaged in an endless race to secure high quality beans. Second, at-length cocoa sourcing puts artisan companies in direct competition with the large candy multinationals, which are quite interested in entering into these niche markets and sourcing high-quality cocoa (i.e., Hershey's and Lindt). Direct trade sourcing — such as Kallari or Askinosie - appears to offer a better option for achieving social and environmental goals than more "at-length" sourcing, but more research is needed to understand the potentials and limitations of this new mechanism for manufacturersproducers collaboration.

My results also suggest that Ecuadorian institutional efforts to protect Ecuadorian fine cocoa production are only partially addressing this underlying issue. My results suggest that the first problem for fine cocoa production is the use of the Arriba label to cover all of the Ecuadorian territory. Arriba may be in fact the best known of all Ecuadorian cocoa varieties, but this designation ignored the marketing potential of 
Ecuador's other historically-strong commercial varieties. A more strict adoption of geographical marketing will allow cocoa producing regions to capitalize out of their own genetic reservoirs. Historical data suggest that fine cocoa is to be found in other Ecuadorian regions, but this issue needs to be explored.

I suggest that the adoption of new forms of varietal nomenclature (i.e., Motamayor et al. 2008 molecular markers proposal of a nomenclature based on 10 sources of cocoa diversity) may contribute to the rescue of endangered genotypes. Centralized efforts to develop Nacional varieties should be focused to restricted geographical ranges, trying to identify and propagate locally-adapted ecotypes. The findings of Motamayor et al. (2008) are that the Nacional genotype exists in areas other than Ecuadorian Western lowlands (i.e., Southern Ecuadorian Amazon region) which suggest that farmers in Western and Eastern Ecuador should be able to develop their own attractive varieties. 


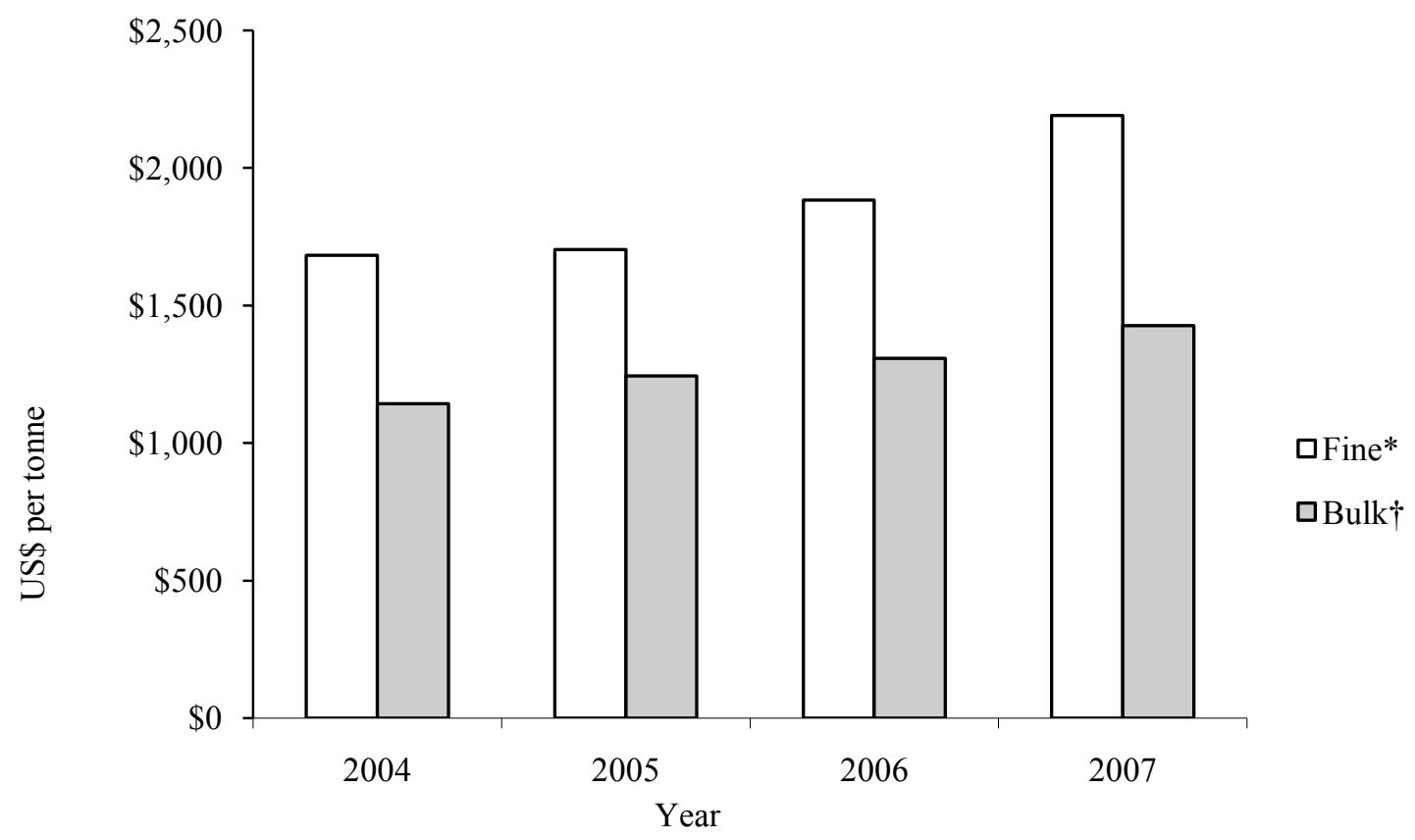

Figure 1. Price by weight of cocoa beans (in US\$ per tonne), 2004-2007, showing price differential for fine versus bulk cocoa beans. Source: FAOSTAT 2010, ICCO 2010.

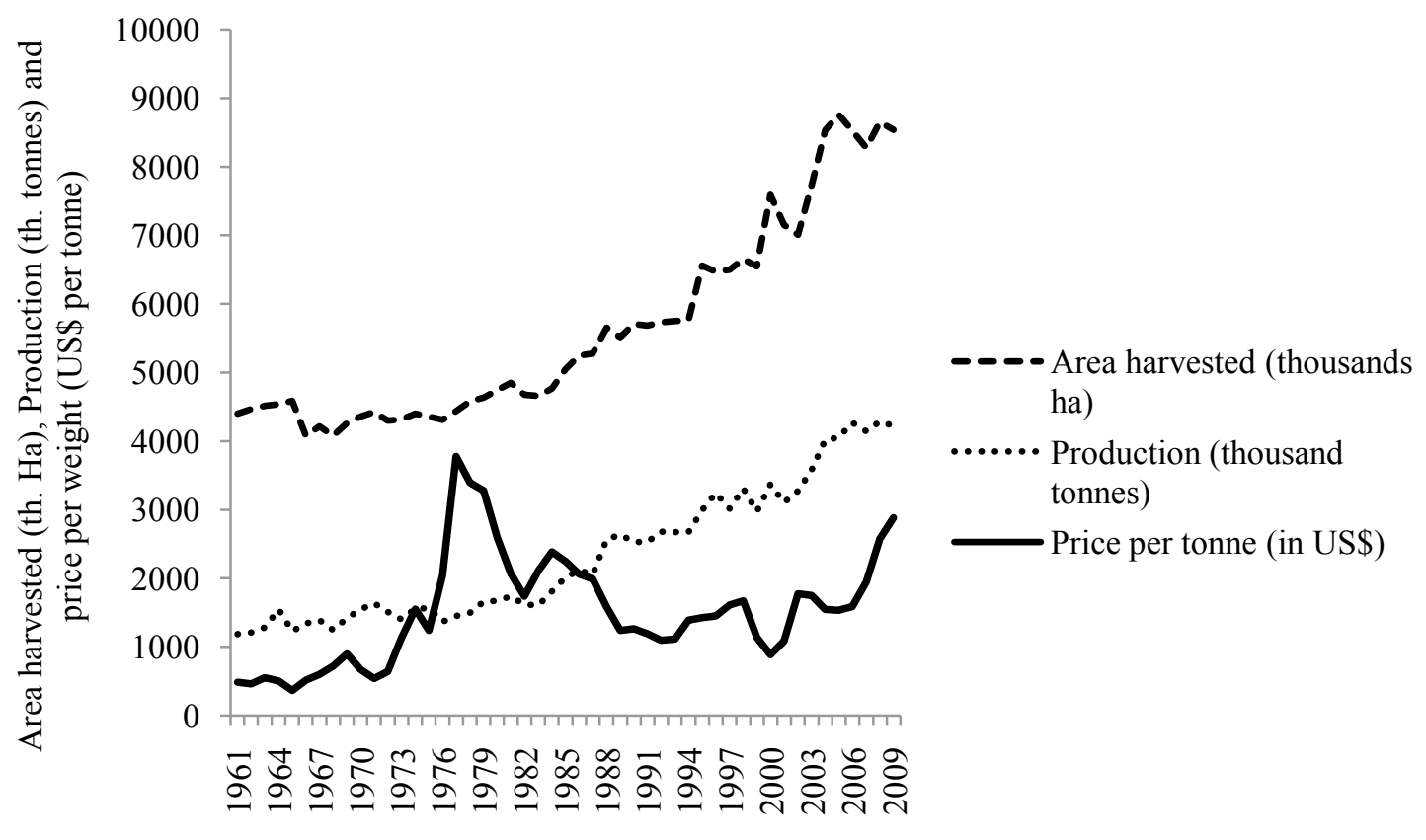

Year

Figure 2. World's cocoa area harvested (in thousands of ha), production (in thousand tonnes) and price per weight (in US\$ per tonne), 1961-2009. Source: FAOSTAT 2010. 


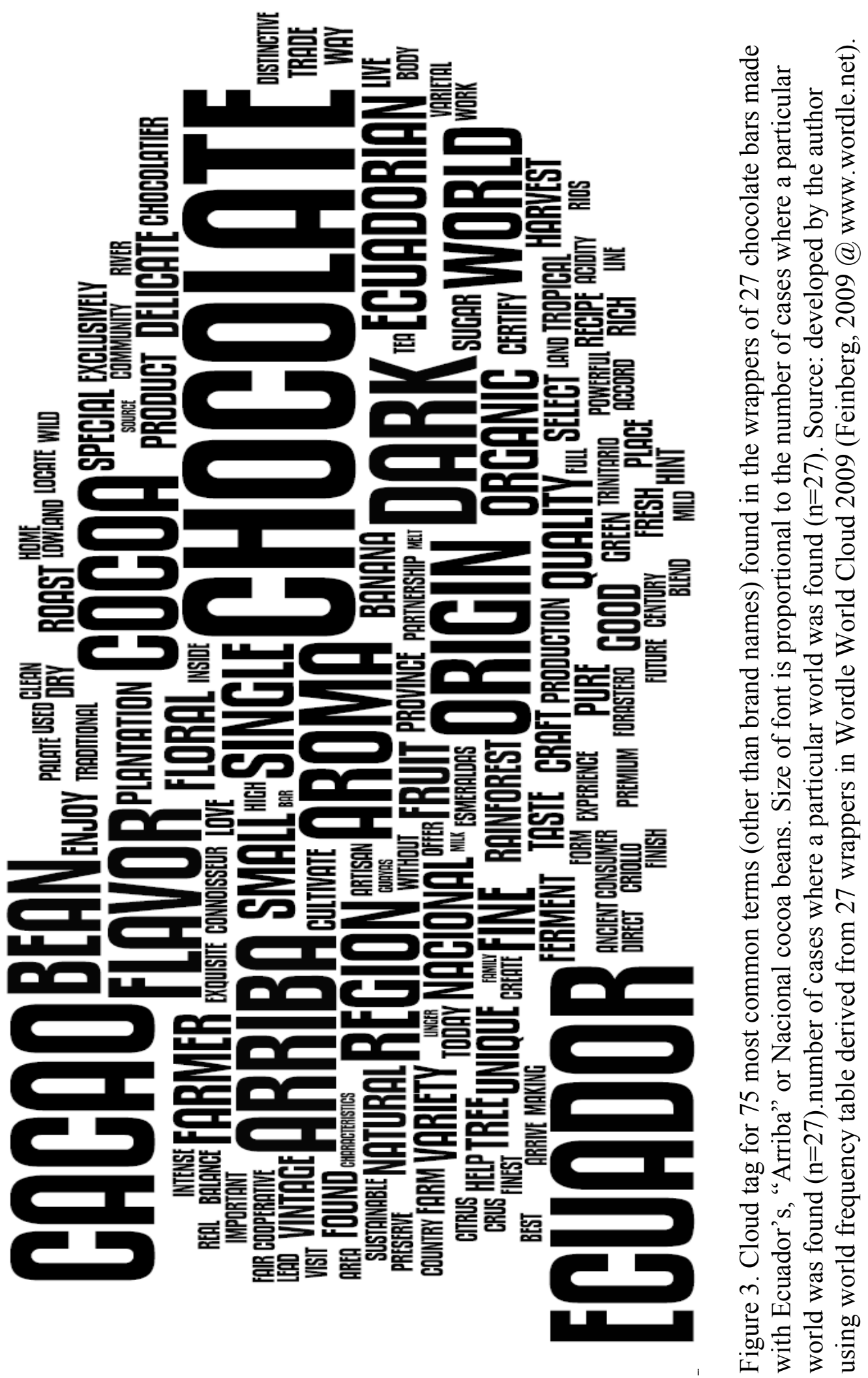


Table 1 . Chocolate bars by brand, $\%$ of cocoa solids, manufacturer and country of origin of manufacturer

\begin{tabular}{|c|c|c|}
\hline Name, brand and \% cocoa & Manufacturer & $\begin{array}{l}\text { Country of } \\
\text { manufacturer }\end{array}$ \\
\hline Amano Guayas $70 \%$ & Amano Chocolate & USA \\
\hline Amedei Ecuador 70\% & Amedei & Italy \\
\hline Ashumira Shumiral (Azuay) n/d † & Agricola Shumiral & Ecuador \\
\hline $\begin{array}{l}\text { Askinosie San Jose del Tambo Nibble } \\
\text { Bar } 70 \%\end{array}$ & Askinosie Chocolate & USA \\
\hline Cacaoyere Cumba (Esmeraldas) 71\% & Ecuatoriana de Chocolates & Ecuador \\
\hline El Eno (Amazonia) 63\% & “ & “ \\
\hline Las Naves (Bolivar) 82\% & “ & ، \\
\hline Puerto Quito (Pichincha) 91\% & ، & ، \\
\hline Caoni Esmeraldas 55\% & BLK Corporation & “ \\
\hline Los Ríos 77\% & “ & “ \\
\hline Chocolat Bonnat Equateur 75\% & Voiron & France \\
\hline Chocolove XOXOX Ecuador $72 \%$ & Chocolove & USA \\
\hline $\begin{array}{l}\text { Corporacion Fortaleza del Valle } \\
\text { Calceta (Manabí) } 60 \% \dagger\end{array}$ & Pacari & Ecuador \\
\hline Dagoba Los Ríos 68\% & Dagoba & USA \\
\hline Domori Cacao Arriba 70\% & Domori & Italy \\
\hline Cacao Cult Ecuador 70\% & “ & “ \\
\hline E. Guittard Quevedo (Los Ríos) 65\% & $\begin{array}{l}\text { Guittard Chocolate } \\
\text { Company }\end{array}$ & USA \\
\hline Fino de Aroma 45\% & El Salinerito & Ecuador \\
\hline $\begin{array}{l}\text { Francois Pralus Equateur Fortissima } \\
80 \%\end{array}$ & Pralus S.A.S. & France \\
\hline Equateur Trinitario $75 \%$ & “ & " \\
\hline Hachez Cocoa d'Arriba 77\% & Hachez Chocolate & Germany \\
\hline Hershey's Cacao Reserve Arriba 50\% & The Hershey Company & USA \\
\hline Hoja Verde $58 \%$ & Hoja Verde & Ecuador \\
\hline Kallari 75\% & Ecuatoriana de Chocolates & Ecuador \\
\hline $85 \%$ & “ & “ \\
\hline Roberto's Recipe 75\% & El Salinerito & " \\
\hline Lindt Excellence Ecuador $75 \%$ & Lindt Switzerland & Switzerland \\
\hline Nestle Dark 60\% & Nestle Ecuador & Ecuador \\
\hline Pacari Esmeraldas $60 \%$ & SKS-Ecuadorian Organics & “6 \\
\hline Manabí 65\% & “ & “6 \\
\hline Republica del Cacao El Oro 67\% & Confiteca & “6 \\
\hline Los Ríos $75 \%$ & “ & “6 \\
\hline Manabí 75\% & “ & “ \\
\hline
\end{tabular}


Table 1. Continued

\begin{tabular}{lll} 
Name, brand and \% cocoa & Manufacturer & $\begin{array}{l}\text { Country of } \\
\text { manufacturer }\end{array}$ \\
\hline Salgado Grand Cru Esmeraldas 70\% & $\begin{array}{l}\text { Sucesores de Jose Salgado } \\
\text { SAIC }\end{array}$ & Argentina \\
UNOCACE Floral 75\% $\dagger$ & Tulicorp & Ecuador \\
Valrhona Alpaco Ecuador 66\% & Valrhona & France \\
Vintage Plantations 90\% & Vintage Plantations Ecuador & Ecuador \\
Zooter Labooko Single Machala (El & Zotter Schokoladen & Austria \\
Oro) $60 \%+$ & Manufaktur & \\
\hline
\end{tabular}

All bars were commercially available at the time of collection unless marked: $\uparrow$ Promotional bar; $\$$ Courtesy of Mark Christian (C-Spot). 
Table 2. Sources of cocoa, number of bars, scale of sourcing, place, and area (in sq $\mathrm{km}$ ) of place

\begin{tabular}{|c|c|c|c|c|c|c|}
\hline \multirow[b]{2}{*}{ Source of cocoa } & \multirow[b]{2}{*}{ Bars $(n=39)$} & \multicolumn{3}{|c|}{ Internal level of sourcing } & \multirow{2}{*}{\multicolumn{2}{|c|}{ Area (sq. km) }} \\
\hline & & Province/s & Canton & Parish & & \\
\hline \multicolumn{7}{|l|}{ Continent } \\
\hline South America & 1 & & & & $20,421,180$ & $\mathrm{a}$ \\
\hline \multicolumn{7}{|l|}{ Country } \\
\hline Ecuador & 16 & & & & 256,369 & $\mathrm{~b}$ \\
\hline \multicolumn{7}{|l|}{ Region } \\
\hline Ecuadorian Amazon & 3 & Morona & All included & All included & 11,6178 & $\mathrm{c}$ \\
\hline & & Napo & & & & \\
\hline & & Orellana & & & & \\
\hline & & Pastaza & & & & \\
\hline & & Sucumbios & & & & \\
\hline & & Zamora & & & & \\
\hline \multicolumn{7}{|l|}{ Province } \\
\hline El Oro & 1 & El Oro & 66 & 6 & 5,817 & $\mathrm{~b}$ \\
\hline Esmeraldas & 3 & Esmeraldas & 6 & “6 & 15,576 & $\mathrm{~b}$ \\
\hline Guayas & 1 & Guayas & “6 & “، & 17,140 & d \\
\hline Los Ríos & 3 & Los Ríos & “6 & “6 & 7,151 & $\mathrm{~b}$ \\
\hline Manabí & 2 & Manabí & 66 & “6 & 18,894 & $\mathrm{~b}$ \\
\hline \multicolumn{7}{|l|}{ Canton/Parish } \\
\hline Calceta, Manabí & 1 & Manabí & Bolivar & $"$ & 445 & $\mathrm{e}$ \\
\hline & & & Chone & & & \\
\hline & & & Portoviejo & & & \\
\hline & & & Tosagua & & & \\
\hline
\end{tabular}


Table 2. (continued)

\begin{tabular}{|c|c|c|c|c|c|c|}
\hline \multirow[b]{2}{*}{ Source of cocoa } & \multirow[b]{2}{*}{ Bars $(n=39)$} & \multicolumn{3}{|c|}{ Internal level of sourcing } & \multirow{2}{*}{\multicolumn{2}{|c|}{ Area (sq. km) }} \\
\hline & & Province/s & Canton & Parish & & \\
\hline \multicolumn{7}{|l|}{ Canton/Parish } \\
\hline Cumba, Esmeraldas & 1 & Esmeraldas & Atacames & "6 & 511 & $\mathrm{f}$ \\
\hline El Eno, Amazonia & 1 & Sucumbios & Lago Agrio & El Eno & 448 & $\mathrm{~g}$ \\
\hline Las Naves, Bolivar & 1 & Bolivar & Las Naves & All included & 147 & $\mathrm{~h}$ \\
\hline $\begin{array}{l}\text { Machala, El Oro } \\
\text { (UROCAL) }\end{array}$ & 1 & Guayas & $\begin{array}{l}\text { Naranjal } \\
\text { Balao }\end{array}$ & Some included & 4,951 & $\mathrm{i}$ \\
\hline & & Azuay & Pucara & & & \\
\hline & & El Oro & El Guabo & & & \\
\hline & & & Santa Rosa & & & \\
\hline & & & Machala & & & \\
\hline Puerto Quito, Pichincha & 1 & Pichincha & Puerto Quito & All included & 683 & $\mathrm{j}$ \\
\hline Quevedo, Los Ríos & 1 & Los Ríos & Quevedo & “ & 302 & $\mathrm{k}$ \\
\hline $\begin{array}{l}\text { San Jose del Tambo, } \\
\text { Bolivar }\end{array}$ & 1 & Bolivar & Chillanes & $\begin{array}{l}\text { San Jose del } \\
\text { Tambo }\end{array}$ & 242 & 1 \\
\hline Shumiral, Azuay & 1 & Azuay & Pucara & Ponce Enriques & 642 & $\mathrm{~m}$ \\
\hline
\end{tabular}

Note: Ecuador's subdivisions are as follow: Country $>$ Province $>$ Canton $>$ Parish. "Regions" are used to group provinces but are not an official political division category (to May 05 2010).

Sources: ${ }^{\mathrm{a}}$ World Bank (2008); ${ }^{\mathrm{b}}$ INEC, $2005 ;{ }^{\mathrm{c}}$ Calculated from INEC (2005); ${ }^{\mathrm{d}}$ Calculated from INEC, 2002a; ${ }^{\mathrm{e}}$ Calculated from INEC, 2002b and information from Fortaleza del Valle (2010); ${ }^{\mathrm{f}}$ INEC, 2002c; ${ }^{\mathrm{g}}$ Estimated from INEC, 2002d; ${ }^{\mathrm{h}}$ INEC, 2002e; ${ }^{\mathrm{i}}$ INEC, 2002f, INEC, 2002g, INEC, 2002h, Ponce Enriquez (2010) and information from UROCAL (2010); ${ }^{\mathrm{j}}$ INEC, 2002i; ${ }^{\mathrm{k}}$ INEC, 2002j; ${ }^{1}$ INEC, 2002j; ${ }^{\mathrm{m}}$ Ponce Enriquez (2010) 


\section{REFERENCES}

Andersson, Meike S, and S Robbert Gradstein. 2005. Impact of management intensity on non-vascular epiphyte diversity in cacao plantations in western Ecuador. Biodiversity \& Conservation 14: 1101-1120.

Bardhan, Pranab. 2006. Globalization and Rural Poverty. World Development 34(8): 1393-1404.

Barrett, H R, A W Browne, P J C Harris, and K Cadoret. 2002. Organic certification and the UK market organic imports from developing countries. Food Policy 27: 301318.

Belsky, Jill M, and Stephen F Siebert. 2003. Cultivating cacao Implications of sun-grown cacao on local food security and environmental sustainability. Agriculture and Human Values 20: 277-285.

Bentley, Jeffery W, Eric Boa, and John Stonehouse. 2004. Neighbor Trees Shade, Intercropping, and Cacao in Ecuador. Human Ecology 32(2): 241-270.

Berlan, Amanda. 2009. Child labour and cocoa: whose voices prevail?. International Journal of Sociology and Social Policy 29(3-4): 141-151.

Bisseleua, D H B, A D Missoup, and S Vidal. 2009. Biodiversity conservation, ecosystem functioning, and economic incentives under cocoa agroforestry intensification. Conservation Biology 23(5): 1176-84.

Blowfield, Mick. 2003. Ethical supply chains in the cocoa, coffee and tea industries. Greener Management International 43: 15-24.

Browne, A W, P J C Harris, A H Hofny-Collins, N Pasiecznik, and R R Wallace. 2000. Organic production and ethical trade: definition, practice and links. Food Policy 25(1): 69-89.

Byskov, Bertil, and Hans Scheu. 1991. Specialty Cocoa Beans: A Market to Watch Carefully. International Trade Forum 27(1): 26-29.

Cardozo, Manoel. 1961. Slavery in Brazil as Described by Americans, 1822-1888. The Americas 17(3): 241 - 260.

Clough, Yann, Heiko Faust, and Teja Tscharntke. 2009. Cacao boom and bust: sustainability of agroforests and opportunities for biodiversity conservation. Conservation Letters 2(5): 197-205.

Crespo, Silvio. 1986. Cacao Beans Today. Lititz: Author. 
Deheuvels, O, B Decazy, R Perez, G Roche, and F Amores. 2004. The first Ecuadorean 'Nacional' cocoa collection based on organoleptic characteristics. Trop. Sci. 44: 23-27.

Espinosa, José, Francisco Mite, Sergio Cedeño, Sandra Barriga, and Javier Andino. 2006. Management of Cocoa. Better Crops 90(1): 36-39.

FAOSTAT. 2010. Production and Trade statistics. Food and Agriculture Organization. http://faostat.fao.org/ Accessed online 01/01/2010-09/20/2010

Faria, Deborah, and Julio Baumgarten. 2007. Shade cacao plantations (Theobroma cacao) and bat conservation in southern Bahia, Brazil. Biodiversity \& Conservation 16: 291-312.

Franzen, Margaret, and Monique Mulder Borgerhoff. 2007. Ecological, economic and social perspectives on cocoa production worldwide. Biodiversity \& Conservation 16: 3835-3849.

Golding, K. M. 2008. Fair Trade's Dual Aspect: The Communications Challenge of Fair Trade Marketing. Journal of Macromarketing 29(2): 160-171.

Greenberg, Russell, Peter Bichier, and Andrea Cruz Angón. 2000. The conservation value for birds of cacao plantations with diverse planted shade in Tabasco, Mexico. Animal Conservation 3: 105-112.

Griffith, Gareth W. 2004. Witches brooms and frosty pods threats to world cacao production. Biologist 51(2): 71-75.

Grimes, John. 2009. Rediscovering the Cacao in Ecuador's Upper Napo River Valley. Focus on Geography 51(4): 23-20.

Haro-Carrion, Xavier, Tannya Lozada, Hugo Navarrete, and G H J de Koning. 2009. Conservation of Vascular Epiphyte Diversity in Shade Cacao Plantations in the Choco Region of Ecuador. Biotropica 41(4): 520-529.

Hayes, DJ, SH Lence, and Andrea Stoppa. 2004. Farmer-owned brands? Agribusiness 20(3): 269-285.

Hebbar, Prakash K. 2007. Cacao Diseases Important Threats to Chocolate Production Worldwide Cacao Diseases A Global Perspective from an Industry Point of View. Phytopathology 97(12): 1658-1663.

Henderson, Paul. 1997. Cocoa, Finance and the State in Ecuador, 1895-1925. Bulletin of Latin American Research 16(2): 169-186. 
Hermessen, J L. 1917. A Journey on the Rio Zamora, Ecuador. Geographical Review 4(6): 434-449.

Hollander, G.M. 2003. Re-naturalizing sugar: narratives of place, production and consumption. Social \& Cultural Geography 4(1): 59-74.

Holloway, H.L. 1932. East of the Ecuadorian Andes. The Geographical Journal 80(5): 410-419.

ICCO. 2006. International Cocoa Organization Annual Report 2004/2005 London: International Cocoa Organization [www.icco.org].

ICCO. 2008. ASSESSMENT OF THE MOVEMENTS OF GLOBAL SUPPLY AND DEMAND EX/136/6 3 April 2008. Executive Committee 136 Meeting. Berlin: International Cocoa Organization http://www.icco.org

ICI. 2010. International Cocoa Initiative: Working Towards Responsible Labour Standards for Cocoa Growing. International Cocoa Initiative. Accesed from http://www.cocoainitiative.org/

ICCO. 2010. ICCO Monthly and Annual Averages of Daily Prices of Cocoa Beans, 1960-2006. London: International Cocoa Organization Accesed 04/12/2010 http://www.icco.org

INEC. 2002a. Difusion de los resultados definitivos del VI Censo de Poblacion y V de Vivienda 2001: Provincia de Azuay, Canton Pucara. Quito. Accesed from http://www.inec.gov.ec/

INEC. 2002b. Difusion de los resultados definitivos del VI Censo de Poblacion y V de Vivienda 2001: Provincia de Bolivar, Canton Chillanes. Quito. Accesed from http://www.inec.gov.ec/.

INEC. 2002c. Difusion de los resultados definitivos del VI Censo de Poblacion y V de Vivienda 2001: Provincia de Bolivar, Canton Las Naves. Quito. Accesed from http://www.inec.gov.ec/.

INEC. 2002d. Difusion de los resultados definitivos del VI Censo de Poblacion y V de Vivienda 2001: Provincia de El Oro. Quito. Accesed from http://www.inec.gov.ec/.

INEC. 2002e. Difusion de los resultados definitivos del VI Censo de Poblacion y V de Vivienda 2001: Provincia de Esmeraldas, Canton Atacames. Quito. Accesed from http://www.inec.gov.ec/. 
INEC. 2002f. Difusion de los resultados definitivos del VI Censo de Poblacion y V de Vivienda 2001: Provincia de Guayas. Director. Quito. Accesed from http://www.inec.gov.ec/.

INEC. 2002g. Difusion de los resultados definitivos del VI Censo de Poblacion y V de Vivienda 2001: Provincia de Los Ríos, Canton Quevedo. Quito. Accesed from http://www.inec.gov.ec/.

INEC. 2002h. Difusion de los resultados definitivos del VI Censo de Poblacion y V de Vivienda 2001: Provincia de Manabí. Quito. Accesed from http://www.inec.gov.ec/.

INEC. 2002i. Difusion de los resultados definitivos del VI Censo de Poblacion y V de Vivienda 2001: Provincia de Pichincha, Canton Puerto Quito. Quito. Accesed from http://www.inec.gov.ec/.

INEC. 2002j. Difusion de los resultados definitivos del VI Censo de Poblacion y V de Vivienda 2001: Provincia de Sucumbios, Canton Lago Agrio. Quito. Accesed from http://www.inec.gov.ec/.

INEC. 2005. Difusion de los resultados definitivos del VI Censo de Poblacion y V de Vivienda 2001: Ecuador. Instituto Ecuatoriano de Estadistica y Censos (Ecuador). Quito. Accesed from http://www.inec.gov.ec.

Knapp, Arthur W. 1920. Cocoa and chocolate: Their History from Plantation to Consumer. Chemist. 1920 ed. London: Chapman and Hall, Ltd.

LeClair, Mark S. 2002. Fighting the Tide: Alternative Trade Organizations in the Era of Global Free Trade. World Development 30(6): 949-958.

Lerceteau, Estelle, James Quiroz, Jorge Soria, Sophie Flipo, Vincent Petiard, and Dominique Crouzilat. 1997. Genetic differentiation among Ecuadorian Theobroma cacao L. accessions using DNA and morphological analyses. Euphytica 95: 77-87.

Lery, Francois. 1954. Le Cacao. 1st Edition. Paris: Presses Universitaires de France.

Low, William, and Eileen Davenport. 2005. Postcards from the Edge Maintaining the 'Alternative' Character of Fair Trade. Sustainable Development 13: 143-153.

Manzo, Kate. 2005. Modern slavery, global capitalism and deproletarianisation in West Africa. Review of African Political Economy 106: 521-534. 
McDonagh, Pierre. 2002. Communicative campaigns to effect anti-slavery and fair trade: The cases of Rugmark and Cafédirect. European Journal of Marketing 36(5/6: 642-666.

McMichael, Philip. 2000. The power of food. Agriculture and Human Values 17: 21-33.

Murray, D L, and L T Raynolds. 2000. Alternative trade in bananas: obstacles and opportunities for progressive social change in the global economy. Agriculture and Human Values 17(1): 65-74.

Nesto, Bill. 2010. Discovering Terroir in the World of Chocolate. Gastronomica 10(1): 131-135.

Niles, Daniel, and Robin Roff Jane. 2008. Shifting agrifood systems: the contemporary geography of food and agriculture; an introduction. GeoJournal 71: 1-10.

Nkamleu, Guy B., and Anne Kielland. 2006. Modeling farmers' decisions on child labor and schooling in the cocoa sector: a multinomial logit analysis in Cote d'Ivoire. Agricultural Economics 35(3): 319-333.

Parsons, James J. 1957. Bananas in Ecuador A New Chapter in the History of Tropical Agriculture. Economic Geography 33(3): 201-216.

Pay, Ellen. 2009. Increasing incomes and food security of small farmers in West and Central Africa through exports of organic and fair-trade tropical products. Rome: Food and Agriculture Organization (FAO).

Pearce, David. 2004. Environmental market creation: saviour or oversell?. Portuguese Economic Journal 3: 115-144.

Phillips-Mora, W., and M J Wilkinson. 2007. Frosty Pod of Cacao A Disease with a Limited Geographic Range but Unlimited Potential for Damage. Phytopathology 97(12): 1644-1647.

Pineo, Ronn F. 2007. Ecuador and the United States: useful strangers. Athens: University of Georgia Press.

Raynolds, Laura. 2000. Re-embedding global agriculture: The international organic and fair trade movements. Agriculture and Human Values 17(3): 297-309.

Rice, Robert A, and Russell Greenberg. 2000. Cacao Cultivation and the Conservation of Biological Diversity. Ambio 29(3): 167-173.

Satre, Lowell J. 2005. Chocolate on Trial: Slavery, Politics, and the Ethics of Business. Athens: Ohio University Press. 
Shreck, Aimee. 2005. Resistance, redistribution, and power in the Fair Trade banana initiative. Agriculture and Human Values: 17-29.

Slater, Candace. 2004. Marketing the 'rain forest': Raw Vanilla fragrance and the ongoing transformation of the jungle. Cultural Geographies 11(2): 165-180.

Talbot, John M. 2002. Tropical commodity chains, forward integration strategies and international inequality: coffee, cocoa and tea. Review of International Political Economy 9(4): 701-734.

Thomas, Jonathan. 2008. Chapter 2 Global market overview. Global market review of premium chocolate - forecasts to 2011. Bromsgrove: Just Food.

Tyler, Charles Dolby. 1894. The River Napo. The Geographical Journal 3(6): 476-484.

Whitkus, R.,M. de La Cruz, L. Mota-Bravo, and A. Gomez-Pompa. 1998. Genetic diversity and relationships of cacao (Theobroma cacao L .) in southern Mexico. Theoretical and Applied Genetics (TAG) 96: 621-627.

Whymper, Robert. 1921. Cocoa and chocolate, their chemistry and manufacture. Second Edition. Philadelphia: P. Blakiston's Son \& Co.

William Gervase Clarence-Smith. 1993. Cocoa Plantations and Coerced Labor in the Gulf of Guinea, 1870-1914. In Breaking the chains: slavery, bondage, and emancipation in modern Africa.Martin A. Klein, 150-169. Madison: The University of Wisconsin Press.

Wolf, T. H. 1893. The Western Lowland of Ecuador. The Geographical Journal 1(2): 154-157.

USDS. 2006. Trafficking in persons report. Publication \#11407. Trends in Organized Crime. Washington D.C.: United States Department of State.

van Hall, Constant Johan Jacob. 1914. Cocoa. London: Macmillan and Co, Ltd.

Vintage Plantations. 2010. The origins of chocolate since 1997. New Jersey: Vintage Plantations. http://www.vintageplantations.com

World Bank. 2008. Open Data Database. Washington D.C: World Bank. http://data.worldbank.org/ 


\section{CHAPTER III.}

\section{ON THE PATH OF SUSTAINABLE DEVELOPMENT}

\section{Introduction and Background}

Globalization is eroding the livelihoods of small farmers, a significant and vulnerable class, particularly in the developing world. The cost-price squeeze stemming from trade liberalization places farmers in a "race to the bottom" that leads to displacement, poverty, and environmental degradation (Porter 1999). It has been proposed that alternative trade initiatives offer a unique opportunity to reverse this trend by harnessing the power of the markets to reward producers of goods with embedded superior cultural, environmental, and social values (Goodman and DuPuis 2002; Bryant and Goodman 2004; McMichael 2000).

Policy makers — influenced by the narrative of 'sustainability through consumption'- attempt to solve allocation issues by fomenting partnerships that encourage the de-commoditization of consumer's products by creating niche markets that cater to the sensibilities of the Northern activist consumers (Bryant and Goodman 2004). These initiatives — under the umbrella of 'sustainable development' (Brundtland 1987) seek to address social, economic, and environmental problems of contemporary food systems (Bingen, Serrano, and Howard 2003). Thus, it is posed that parallel systems of trade provide solutions to structural problems of commodity production and trade, such as an export's oligopoly, scale-biased regulatory regimes, and markets' failure to account for provision of environmental and social services. Alternative trade networks are visualized as institutional arrangements through which the benefit generated by smallscale, low-input agricultural producers are valorized (Moberg 2005; Gómez Tovar et al. 
2005; Brown and Getz 2008). Thus, alternative trade networks create 'partnerships of virtue' that challenge the transnationally-dominated global food system (McMichael 2000).

Under the banner of a common understanding of the "necessity, desirability and universality" of sustainability (Luke 2005), local and international agencies vie for producers to joint alternative trade development schemes. However, the discursive concept of a partnership based in equity and mutual benefit (Ashman 2001) belie differences at both ends of the commodity chain: what for consumers it is a matter of expressing choice, for producers it is a matter of survival (Moberg 2005). The discourse of sustainability becomes normative, because producers must meet their international partner's standards to gain access to capital (Melo and Wolf 2007). The disparity points to the need to question the effectiveness of these partnerships, given that - underlying the design and execution of any sustainable development project—-there is a bare-naked power differential between rural commodity producers and the globalized technocratic elite who lead these programs.

In this chapter, I analyze the results of the alliance of Ecuador's Cacao Producers Federation (Federacion Nacional de Productores de Cacao del Ecuador, FEDECADE), its Ecuadorian NGO counterpart (currently known as Fundacion Alianza CEIDE, ${ }^{18}$ or CYD), and a heterogeneous set of international donors. These projects spanned 10 years (1997-2008), and nominally invested roughly US\$ 1200 for each of the farmers involved

\footnotetext{
${ }^{18}$ This NGO has been known as Corporacion of Conservacion y Desarrollo (CCD, 19922000), Conservacion y Desarrollo (CYD, 2001-2007), and Fundacion Alianza CEIDE (2007-current) (Juan Lecaro, electronic interview with author, 05/04/2010)
} 
(US\$1,436,738 per 1172 families). The shared goal of these projects was to create an alternative commercialization system that paid a fair value for the farmer's shade-grown fine cocoa known as Nacional. Shade-grown Nacional cocoa plantations are prized by conservationists because these multi-strata agro-forestry systems provide environmental goods and services - habitat for endangered wildlife species and protection to local water courses - that are lost when they are converted to other crops systems (i.e., bananas or full-sun cocoa). My focus is in the benefit reaped by farmers in the area of influence of FEDECADE and beyond, one year after FEDECADE commercialization system ceased to operate.

\section{Methods}

The study was conducted on Ecuador's western lowlands, from May to December of 2009 (Figure 1). Fieldwork was conducted in the area of influence of FEDECADE, in the provinces of Azuay, El Oro and Guayas. The study gathered data from three sources: in-depth interviews with farmers, farmer's leaders, and NGOs and founding agencies personnel, an open-answer survey applied to 100 farmers, and the physical and digital archives of FEDECADE and CYD. Interviews with cocoa exporters, NGO staff, and other informants were conducted on an ad hoc basis.

The in-depth interview script was designed to gather information about the experiences of farmer's organization with cocoa commercialization, interactions with local and external agencies, and a general feeling about the state of the industry from a farmer's perspective. The interviews were conducted in Spanish, in an ad-hoc basis, based upon participant willingness and time availability. I interviewed farmers and farmers' leaders from all FEDECADE cooperatives or associations. I also conducted in- 
depth interviews with farmers that hold positions of leadership on their community's cocoa commercialization team. The interviews with farmers were complemented with interviews with FEDECADE representatives and staff, government and non-profit organization officials, cocoa exporters, other farmer's organizations representatives and cocoa town-level intermediaries.

The second data source consists of an open-answer survey applied to cocoa producers from Guayas and Azuay (Appendix 1). These producers were included in the records of FEDECADE. At the time of the study, a FEDECADE farmer could hold up to three certifications (Fair Trade, Organic and Rainforest Alliance). The survey was conducted at each participant's residence. In total, I conducted 100 of these surveys. The survey consisted of four parts. The first, personal history, included questions that establish age, gender and background of the farmers in the sample. The second, land management, gathered information about the amount of land managed, and the level of fragmentation of this area. The third, cocoa and other crop production, asked questions about the crops managed by each farmer (including questions about crop variety, yield, and age of the crops); it also included questions about subjective perceptions about the benefits and liabilities of cocoa varietals. Finally, commercialization and income, asks questions about the income generated by cocoa under different selling modalities, and asked about the contribution of other economic activities to farmer's income. Farmer's were recruited in the sample depending on their willingness to participate in the study, on the basis of two criteria: a) de-facto management of the land, b) being included in the rolls of associations registered with FEDECADE. The application of these two criteria 
yielded a sample of 100 farmers out of 430 registered with FEDECADE's Nueva Union Campesina, 6 de Julio, Camacho and La Florida Associations.

The third data source consisted of approximately $277 \mathrm{MB}$ ( $\sim 40$ files) available in FEDECADE's computers up to December of 2009; 194 MB of the Conservacion y Desarrollo (CYD) cocoa project ( $\sim 1000$ files), and of 176 documents made publicly available by CYD at the social publishing website Scribb [www.scribb.com]. The two groups have produced documents that are not included in these repositories, but these digital files are an archive that has been preserved in the face of changing technology, frequent failure of electronic equipment, and lack of backups. The associations and cooperatives of FEDECADE kept their commercialization records on Microsoft Excel files, which sometimes had formula or format problems [i.e., errors in SUM range assignation, or use of a "comma" for decimal points]. These problems were corrected, but the data are otherwise reported as they appear in FEDECADE's databases. From 2003 to 2008, FEDECADE associations stocked and sold six types of cocoa [Nacional Faitrade Organic, Nacional Organic, Nacional Rainforest Alliance, Nacional conventional, CCN51 conventional and monilla ${ }^{19}$ ] to internal and external markets.

I was also granted access to the personal archives stored in the town of Jesus Maria in the residence of FEDECADE's President, Agr. Victor Chacon Salinas. Relevant files were scanned and converted to digital files. Data classification, management and sorting was done using Atlas.Ti.6.1.1.

\footnotetext{
${ }^{19}$ The "monilla" or "negro" are beans from pods damaged by frosty-pod disease, Moniliophthora roreri. These beans are paid at 50\% of the price of "normal" cocoa.
} 
In the results, I distinguish between CYD and FEDECADE. There are two caveats with this study. First, FEDECADE was made into the beneficiary of CYD-devised development projects. Second, CYD was in charge of the projects (from budgeting to coordination). Thus, although FEDECADE was nominally given full responsibility over certain components of the projects, it was limited to executing CYD's plans.

\section{Ecuador's Federation of Cocoa Producers: then and now}

The Ecuador's Federation of Cocoa Producers (known as FEDECADE for the acronym of its Spanish name "Federacion de Productores de Cacao del Ecuador") is a federated non-profit organization constituted in 1981. The FEDECADE membership consisted of 1172 farmers (and their families) grouped in 11 associations located in the provinces of Azuay, Bolívar, Esmeraldas, Guayas, and El Oro (FEDECADE 2008; MAGAP et al. n/d; Transfair 2005) The farmers affiliated with FEDECADE hold 7900 ha of cocoa Nacional, of which 3000 ha were certified under the U.S. based Rainforest Alliance; 1500 ha were certified as Organic by Germany-based BCS Öko-Garantie $\mathrm{GmbH}$, and 600 ha were certified Fairtrade by Germany-based FLO-Cert GmbH (MAGAP et al. n/d). Certifications overlapped, thus a farm could be counted under the three certification schemes simultaneously.

The FEDECADE has a long history of activism advocating for the "economic interests" of Ecuador's small and medium cocoa farmers (Victor Chacon Salinas, interview with author, 12/10/2007). Guided by a pragmatic turn, FEDECADE has evolved from a trade-union organization focused on "defending and advancing Ecuador's small and medium cocoa farmer's interests" (Victor Chacon Salinas, interview with 
author, 12/10/2007), to a one whose stated goal is "to produce and export fine and aroma cocoa" (FEDECADE-Max_Havellar, n/d) ${ }^{20}$

The change in FEDECADE from a 'confront-the-establishment' to an 'exportoriented multi-certified organization' can be traced back to its 1997 involvement with the environmentally oriented CYD, an Ecuadorian Quito-based non-gubernamental organization (NGO). For the next 10 years, CYD acted as FEDECADE's main intermediary for international donors, launching several projects that were nominally focused on maximizing farmer's profits derived from Nacional cocoa plots. In these projects proposals, the alliance among FEDECADE, CYD and international donors was presented as 'win-win' sustainable development partnership operating under a set ofassumed - shared values based in a common understating of the problématique of Ecuadorian Cocoa. For the donors and NGOs, the development of an environmentally oriented certification system for cocoa offered an opportunity to improve cocoa farmer's social and economic welfare while maintaining the provision of environmental services coming out of Nacional shaded cocoa plots (Rios et al. 1997). The alternative commercialization chain was to challenge the traditional middlemen commodity chain in which farmers' gate price per quintal [100 pounds or $45.35 \mathrm{~kg}$ ] that was $63 \%$ (or less) of the market price paid by the exporters in Guayaquil, with the ultimate goal of transferring more resources to the farmers (Desarrollo 2000).

\footnotetext{
${ }^{20}$ This transition from "trade-union" to "money-oriented" is criticized by some ex FEDECADE members, some of which denounced FEDECADE's Chacon Salinas leadership because "it abandoned its role of opposing 'cocoa exporters' by becoming one of them" (Vincente Pidrahita, interview with author, Vinces, 12/08/2007).
} 
For FEDECADE, the alliance with CYD and international donors offered an opportunity to address what the agronomist Victor Chacon Salinas - then and now FEDECADE President, and a cocoa producer on his own-has long contended were the factors that keep small cocoa producers in poverty. Chacon Salinas, in an early 1990s document identified four major problems for Ecuadorian cocoa production at the time: lack of generation and transfer of technology; low gate prices caused by both a malfunctioning local commercialization chain and worldwide cocoa overproduction; lack of credits available for long term, seasonal crops like cocoa; and lack of a suitable cocoa gene bank from which to identify and propagate suitable high yield Nacional cocoa varieties (Chacon Salinas 1990). FEDECADE was hopeful that projects and other private initiatives would be able to fill the aforementioned voids. It was also expected that these projects would address the lingering issue of lowering quality of Ecuadorian cocoa exports, given that the middlemen-mediated chain was said to focus on quantity, not quality (Chacon Salinas 1990). Furthermore, by offering premiums for cocoa produced in shaded plantations, Chacon Salinas (1990) expected that these developments would provide incentives to protect the shade-grown Nacional cocoa ecosystem from the threats of deforestation, soil erosion, and pollution.

The need for private intervention was amplified by the weakening of the Ecuadorian state that followed neoliberal reforms of the 1990s. A series of changes created a situation where there was no clear policy in place, given that new regulatory bodies came into existence only to be replaced after a short tenure. For instance, Ecuador's Cocoa National Program (Programa Nacional del Cacao, PNCC) was closed in 1995 (Rosero 2002). Although financed since 1977 with a $0.5 \%$ tax over the FOB value 
of the cocoa exports, the PNCC has long struggled to fulfill its multiple roles of providing extension services, building infrastructure, and conducting cocoa research and development with a staff of just thirty extension agents to supply the needs of 58,618 farms (what amounted to 1,890 farms per extension agent) (Soria 1986). After being deemed ineffective, in 1989 its regulatory role was delegated to the privately-run nonprofit Agricultural and Animal Husbandry Stock Exchange (Bolsa de Productos Agropecuarios) (Redaccion Expreso 1991; Rosero 2002). The Stock Exchange was financed with $1.5 \%$ of the value FOB of the cocoa exports (of which $0.4 \%$ of the FOB were to be dedicated to develop and implement a cocoa quality certification system, and $1.1 \%$ of the FOB was designated for extension services). When cocoa production reached a historical low in 1998, the efforts of "La Bolsa" were found lacking (Guayaquil 1999a), and the government transferred quality-control and industry development functions to the private Nacional Association of Cocoa Exporters (Asociacion Nacional de Exportadores de Cacao, ANECACAO), which then was funded with $0.42 \%$ of the FOB value of the exports (Rosero 2002). The PNCC extension services were also privatized, with controversial results: (Rivera and Alex 2004; Wong 2006; Flores G. 2007).

The retrenchment of the State also influenced the price paid to cocoa producers. Attempts to foment the local production of cocoa elaborates ${ }^{21}$ — such as cocoa liquor and cocoa paste - were abandoned, after the system of export quotas and price subsidies (for local processors) collapsed under pressure by farmers and exporters in the late 1980s (Norero Gonzalez 1988). The Agricultural and Animal Husbandry Stock Exchange did

\footnotetext{
${ }^{21}$ Cocoa elaborates, such as cocoa licour, cocoa paste and cocoa butter, are a value-added intermediate-step in the industrial process that transforms cocoa beans into chocolate.
} 
not fulfill its promises of creating a "fair and transparent" market for agricultural products, and instead tried (unsuccessfully) to remain in control of all cocoa transactions (Guayaquil 1990).

After cocoa was withdrawn from the Agricultural and Animal Husbandry Stock Market in 1999 (Guayaquil 1999b), Ecuador's internal price for cocoa has been generally set by supply and demand, with the base of a 'referential' price set daily by ANECACAO using data from the Stock Exchanges in New York and London (Rosero, 2002). Farmer's gate price is then set by subtracting intermediation costs from this ANECACAO base price; thus, the gate price is negatively correlated with the length of the commercialization chain.

Small farmers were especially affected by the challenges posed by these institutional changes. While deemed insufficient, the PNCC provided a source of advice that farmers were likely to use on an ad hoc basis (Cesar Carrillo, interview with author, Jesus Maria, 12/17/2007). Further institutional failure drove a severe decline of cocoa quality, which in turn led to the 2005 International Cacao Organization decision to downgrade Ecuador' cocoa rating from $100 \%$ fine flavor cocoa to $75 \%$ (ICCO, 2006). Thus, shaded Nacional plantations came to be seen as an agro-ecosystem under threat. The CYD documents of the time mention that cocoa production was being conducted in an "institutional void," and suggested that development projects could address these problems (Desarrollo 2000). In general, CYD and FEDECADE shared views about the root causes of cocoa production problems, and had a common understanding about ways to address these issues (Valdivieso 2008, Victor Chacon Salinas, interview with author, July 2009). In this narrative, the decline of Nacional is attributed to agricultural factors 
such as low productivity (diseases and lack of resources to maintain and replace plantations), and economic factors such as an oligopolistic internal cocoa market dominated by a few exporters. The loss of cocoa quality was explained as the consequence of a middlemen mediated commodity chain that did not transfer premiums for quality to the farmers and the lack of a system to reward farmers for the value added to Nacional cocoa beans for its fine cocoa quality, as well as for its environmental and social benefits (Desarrollo 1998; Desarrollo 2001; Desarrollo 2000).

However, FEDECADE and CYD shared understanding did not cover all the aspects of cocoa production. The conflict FEDECADE-CYD was centered on the cocoa hybrid known as CCN-51, a full-sun variety developed by Homero U. Castro-a cocoabreeder with an on-and-off friendship with FEDECADE's president (Victor Chacon Salinas, interview with author, July 2009) ${ }^{22}$. Chacon Salinas considered CCN-51's high yield and disease-resistance characteristics as important assets for increasing the income of all cocoa farmers. Chacon Salinas opinion was informed by his years long experience with $\operatorname{cocoa}^{23}$, and stand in contrast with 1997 CYD views of this full-sun variety.

${ }^{22}$ In a paper found during field work, Homero U. Castro describes CCN 51 as a cross of F1 of IMC-67 x ICS-95 by O-1, where O-1 was a cacao ascension collected by himself in a trip to Ecuador's Valle de los Canelos (Castro 1981). According to this paper, CCN stands for Coleccion Castro Naranjal, where 51 is for the cross number of this variety.

${ }^{23}$ Chacon Salinas worked for several years as a cocoa field hand and general laborer before acquiring his degree in Agronomy. As an agronomist, he was hired as Cocoa Assessor for some of the large cocoa haciendas of the Naranjal area, among them Balao Chico. During these years, Chacon Salinas carefully documented how plots planted with directed hybrids or 'selected' clones of "Nacional" (EET series) and other varieties (ICS95; IMC 67, and SCA-12) routinely outperformed plots of "pure' "Nacional" genotypes. Plots planted with selected genetic materials had "very good" or "extremely good" production, yielding 15-20 qq/ha year [681-909 kg/ha year] to those with 'pure' National 
Although CYD personnel acknowledged that $\mathrm{CCN}-51$ has "superior agronomic characteristics," full-sun plantations were seen as a potential environmental threat under the assumption that high yield was linked to the management practices of agro-industrial "monocultures," heavily dependent on inputs such as agrochemical and fertilizers (Rios et al. 1997). The environmental and ecological value of Nacional shaded plantations was spotlighted when comparing these biodiversity-rich agro ecosystems with other local crops (i.e., bananas) in an area where forests were already depleted. The CYD believed that a market niche could be carved for the fine Nacional cocoa, while CCN-51 would have to compete with bulk cocoa (Desarrollo 2000).

After a slow 1995-1997 starting phase which emphasized the development of ecological certification norms ${ }^{24}$, FEDECADE centered projects took a drastic turn to economic development and sustainable development. This shift was caused by the 19971998 El Niño Southern Oscillation (ENSO), which flooded Ecuadorian lowlands (UN, 1998). The 1997-1998 ENSO affected all of Ecuador's regional economy (i.e., agriculture, fisheries, shrimp farming, etc), causing losses that amounted to one quarter of the total agricultural gross internal product (Vos et al. 1999). Twenty percent of the area dedicated to cocoa was flooded, with a loss of 40,000 ha (out of a 1997 estimate of $340,000 \mathrm{ha})$. Even areas that were not flooded were affected by the proliferation of diseases caused by increased humidity and lower luminosity (Vos et al. 1999). Indeed,

or natural hybrids which yielded 7-9 qq/ha year [318-409 kg/ha year] (Chacon Salinas 1983; Chacon Salinas 1986).

${ }^{24}$ Compiled under the name of "Normas para la produccion agricola para cacao del Programa de Certificacion Eco-O.K." Aspects of this normative were later adopted by the Conservation Agriculture Network, the Sustainable Agriculture Network, and the Rainforest Alliance Certified Programs that evolved from this early effort. 
the 1998 harvest was $43 \%$ of the previous year, (see Figure 2), and by 1999 the number of Ecuadorian poor is said to have drastically increased (Vos et al 1999). The economic crisis forced farmers to look for other sources of cash, such as harvesting shade trees or sending family members abroad (Interview with a farmer, Nueva Union Campesina, 2009) ${ }^{25}$.

The effects of the 1998 ENSO are reflected in the narrative of the CYD projects of the time. For example, in its project proposal to INTERMON (a Spanish socially oriented fund) for a commercialization scheme, CYD mentions, "by establishing a standardized and fair commercialization system, the project will improve the livelihood of small farmers' families" (Desarrollo 2000). In this project narrative, environmental certification (which was the leading goal of previously executed projects) becomes a "marketing tool" that "will allow for a better product positioning in potential international markets" (Desarrollo 2001). The CYD narrative of the time makes economic development intrinsically linked to preservation of Nacional cocoa plots, in a shift that brings it in close alignment with FEDECADE's concerns about farmers' welfare (Desarrollo 2001).

The key strategy for achieving these two goals was to increase farmers' incomes by improving farmers' access to the markets. This required three components: infrastructure to process and stock high quality cocoa beans; a group of farmers that had the know-how about how to buy cocoa from other farmers and sell the beans to the

${ }^{25}$ The economic welfare of all Ecuadorians was affected by $1999-2000$ bank crisis (50\% of all banks were closed or transferred to a state agency); a government decree that 'freeze' half the savings of all Ecuadorians, and 2000 Ecuador's adoption of the US dollar as the country's currency. 
exporters, while making turning a "fair" profit; and a commercialization system that would be able improve the income of farmers by bypassing middlemen, with the ultimate goal of exporting certified Nacional cocoa independently. This project was leveraged in the unique "fine and flavored" quality of the Nacional beans, under the assumption that high-end chocolate makers would be willing to pay a higher price for value-added beans.

\section{Investing for Development I: Infrastructure; Training and Extension, and Research and Development, 1995-2008}

INTERMON and other donors agreed to finance the projects. The bulk of the projects investment—accounting for US\$781,200 (54.37\% of the total invested until 2008) — was done from 1999 to 2004, in five years following the 1997-1998 ENSO (see Table 1). Leveraged with a considerable local counterpart, estimated in US\$567,000 in goods and services ${ }^{26}$, FEDECADE-CYD built three new stock centers: 3 de Octubre at Rio Bonito (El Oro); Camacho and Rio Blanco at Luz y Guia Campesina (Azuay), helped pre-associations and farmers groups to built "tendales" (large concrete surfaces used to dry cocoa), and updated and upgraded four ex-PNCC stock centers that were 'on-loan' to the cooperatives of El Progreso (PRO), Nueva Union Campesina (NUC), 6 de Julio (6DJ), La Florida (LFL) y La Delicia. Investing in commercialization infrastructure amounted to US\$ 246,100 from international funds by May of 2003 (Desarrollo 2003). Further investments in infrastructure were made to achieve organic and Fair Trade certification (GTZ, 2002-2004, US\$25,000). Also, FEDECADE and other Ecuadorian

\footnotetext{
${ }^{26}$ For example, farmers from 3 de Octubre (Rio Bonito) (3DO), Camacho (CAM) and Rio Blanco (Luz y Guia Campesina) donated land used to built stock centers; farmers from Rio Bonito, Camacho, working under the shared-work arrangement known as 'minga,' built the stock centers themselves.
} 
farmer's organizations received infrastructure investment from funds provided by the food multinational Kraft, the German international development agency GTZ and the Dutch international development agency DOEN_with the goal of increasing Ecuador's overall output of Rainforest Alliance certified cocoa in a project that extended to the year $2008^{27}$

As a result of these investments, by 2008 FEDECADE had a network of seven stock centers for receiving and processing cocoa from the farmers. The cocoa was then transported to the stock center in Nueva Union Campesina, where it was prepared for exportation. The stock centers had the capacity for serving more than one community (i.e., NUC stock center was stocking cocoa from NUC and 6DJ; LFL stock center was serving LFL and ATAIB). At one time, all of these stock centers had state-of-the-art multi-story cocoa fermenters, solar and gas dryers, and multi-certification compliant storage facilities.

Simultaneously, the projects were training farmers to achieve the goals of increasing production, becoming certified and commercializing certified cocoa (Desarrollo 2000) ${ }^{28}$. Thus, Training and Agricultural Extension accounts for $25 \%$ of the amount invested by the Canadian development agency FECD projects AG-0528 and AG0622 (Desarrollo 2001; 1998); US\$ 40,000 from the project "Sustainable cocoa and

\footnotetext{
${ }^{27}$ Later on, Kraft started sourcing their RA certified cacao from plantations in Western Africa.

${ }^{28}$ While the main goal of the projects was to commercialize cocoa resources were invested in topics of particular interest for the projects' donor.
} 
livelihoods" funded by the U.S. based Overbrook Foundation and an undetermined amount from the other projects.

It should be noted that not all of the resources from these projects were directly invested in FEDECADE. The CYD operation was costly, given that it required mobilizing personnel from Quito to the project area. The CYD counterparts desire for control and accountability, expressed in setting a complex set of goals, procedures, and standards in order to guarantee project execution, developed into a situation where the cost for "project coordination" took as much as $50 \%$ of the budget of the amount invested by the FECD AG-0528 and AG-0622 (Desarrollo 2001; 1998). Evidently, other projects were more efficient but the cost of project administration remained high.

Overall, research and development was the component that received least financing, being limited to US $\$ 25,000$ (1.74\% of the total invested until 2008) from Overbrook Foundation in 2002 for the development of greenhouse-plastic-based solar dryers (later adopted by most Ecuadorian cocoa processing facilities). Additionally, there was approximately $\$ 5,000$ from the FECD AG-0622 project that was used to identify and replicate cocoa promissory local ecotypes (Desarrollo 2001). Other than this, there were no investments in renovating plantations from the project side.

While it was not possible to establish a direct relation between the availability of these training programs and extension services and yield increases, I found evidence that shows yields in the area of study have certainly increased. In 1997, a sample of 30 farmers of the Canton Naranjal shows that the average yield was of $359 \mathrm{~kg} / \mathrm{ha}$ year (this included both Nacional and CCN-51 plots), with Nacional yielding $297.7 \mathrm{~kg} / \mathrm{ha}$ year and CCN-51 yielding $369.5 \mathrm{~kg} / \mathrm{ha}$ year (ECU-B7 1997: 82-84). In my 2009 survey, a 
subsample of farmers located in the Canton Naranjal ( $\mathrm{n}=66,6$ de Julio and Nueva Union Campesina cooperatives) declared an average cocoa yield (counting both Nacional and CCN-51 varieties) of $747.7 \mathrm{~kg} / \mathrm{ha}$ year $(\mathrm{n}=66, \mathrm{SD} 7.64)$, with Nacional plots yielding 354 $\mathrm{kg} / \mathrm{ha}$ year $(\mathrm{n}=66, \mathrm{SD} 3.93)$ and $\mathrm{CCN}-51$ yielding $1100.9 \mathrm{~kg} / \mathrm{ha}$ year (plantings over 5 years, $\mathrm{n}=50$, SD 3.23).

Variety wise, my 2009 survey results indicate FEDECADE affiliated farmers opted for CCN-51 instead of the more traditional Nacional. Of the farmers that have plantings with CCN-51 (n=72), $65(90 \%)$ reported having planted this area within the last 14 years, and $38(52 \%)$ reported that their $\mathrm{CCN}-51$ plantings were younger than 7 years (which falls squarely within the time CYD projects were being executed). Of the 72 farmers in the survey, only one reported that 8 years ago he had planted a plot with cocoa Nacional "de pepa" (from seed). The finding suggests that FEDECADE farmers continued to plant CCN-51, although Nacional-focused projects were running in the area. Thus, despite the large investments by multiple international agencies, farmers were not willing to "put all their eggs in one basket," preferring rather to maintain multiple cocoa varieties.

\section{Investing for development II: commercialization, 2002-2008}

The FEDECADE commercialization system started operating in 2002, with a seed fund consisting of $\$ 60,000$ (US $\$ 10,000$ per cooperative) from a no-interest, refundable loan that was part of the Ecuadorian Canadian Development Fund (Fondo Ecuatoriano Canadiense para el Desarrollo, FECD $)^{29}$ financed AG-0528 and AG-0622 projects, and

${ }^{29}$ Then Fondo Ecuadoriano Canadiense para el Desarrollo (FECD); since 2005, Fideicomiso Ecuatoriano para el Desarrollo (FECD) 
$\$ 25,000$ from the Spanish-based INTERMON 3125 project (see Table 1). By 2003, these early commercialization exercises were operating in all the cooperatives involved; however, "El Progreso," which was the starting point for this initiative, was selling its cocoa to the Union of Cocoa Farmers's Associations (Union de Organizaciones Campesinas Cacaoteras del Ecuador, UNOCACE) (Victor Chacon Salinas, interview with author, 12/05/2009) ${ }^{30}$. Commercialization-ready cooperatives—such as "El Progreso"- became a prize contested by the NGOs and IGOs involved. The thug-of-war among development institutions undermined federated bodies such as FEDECADE.

The belief that chocolate makers would be willing to pay for Nacional beans proved partially true: FEDECADE found clients willing to pay premiums for certified Nacional beans, but these clients were also looking for high quality beans with better than the norm post-harvest treatment (Pierrick Chouard, interview with author, April 2010). The first commercialization scheme, which involved buying dry cocoa beans from the farmers, was abandoned when it was found that this practice lead to irregular cocoa batches. After a troublesome first experience supplying cocoa to Vintage Chocolateswhich was the first company to launch a Rainforest Alliance-certified Nacional chocolate bar back in 2004-FEDECADE and CYD found that quality-wise the best results were achieved if farmers deliver unprocessed "cacao en baba" (wet cocoa beans) to the stock centers, and then the stock center fermented and dried the beans uniformly. While this practice was not new—given that around $10.9 \%$ of the farmers previously wet cocoa

\footnotetext{
${ }^{30}$ UNOCACE was founded in 1999 and started commercializing cocoa in 2002. This organization was financed as a final-product of the European Union-CIRAD-Ecuadorian Ministry of Agriculture Project ECU-B7 3010/93/176, "Reactivacion de la produccion y mejora de la calidad de cacao en Ecuador" (ECU-B7 1997).
} 
beans - most of them preferred to do the post-harvest themselves because middlemen generally took a larger discount from the price than from dried or semi-dried cocoa (ECU-B7 1997).

The response of FEDECADE to these concerns was to deal with the farmers as fairly as possible, running experiments to find a fair "wet-to-dry" conversion ratio and paying a higher overall price. On the other hand, management cost per bean increased, given that now the stock centers assumed the costs (labor and inputs) of post-harvest management. Thus, while in 2003 and 2004 FEDECADE management costs averaged US\$ 0.03 to 0.04 per kg of dry cocoa beans ( $2 \%-3 \%$ of the stock centers expenses), from 2005 to 2008 the management cost averaged in the range of US\$ 0.16 to US\$ 0.33 per $\mathrm{kg}$ of dry cocoa beans ( $11 \%$ to $13 \%$ of the stock center expenses).

By 2004, it become evident that the commercialization funds secured from the INTERMON 3125 and FECD AG-0528/AG-0627 development projects did not cover the needs of the stock centers. Cocoa farmers were adamant about cash-on-delivery transactions, and sometimes would take their beans to another place if there was no cash to pay for their crop - even if their farm was certified.

High expectations were raised with the 2004 creation of the Citibank Foundation financed ${ }^{31}$ FEDECADE's Trust Fund for Cocoa Commercialization (FTFCC). According to CYD, the FTFCC was a financial tool that was designed to grant FEDECADE access to international capital (Valdivieso S. 2008). Cocoa production is seasonal, so FEDECADE only needed a loan from July to December of each year; at the time,

\footnotetext{
${ }^{31}$ In this case, the financing consisted assuming the legal costs to establish the Trust Fund, not a cash donation.
} 
Ecuador's local banking system did not have the flexibility to grant credits for this sort of ventures (Valdivieso S. 2008). Root Capital, (previously known as Ecological Financial) a U.S. based non-profit social investment fund that specialized in providing capital for rural communities - and that had previously financed FEDECADE under a personal guarantee from Chacon Salinas-became the FTFCC's first partner. Starting with US\$150,000 in 2004 (Krenke 2004), in 2006, Root Capital loaned US\$300,000 to the FTFCC at a yearly interest rate of $9 \%$ (at the time, the interest rate for a commercial credit in Ecuador was 12-15\%) (Estudios 2006); in 2007, it loaned the FTFCC US $\$ 400,000$; and in 2008, it loaned the FTFCC US\$300,000.

From 2004 to 2008, Root Capital funded the FTFCC on a non-conditional basis: credit was granted to FEDECADE (via FTFCC) to buy cocoa, FEDECADE associations stocked cocoa, and FEDECADE sold their stocks to the best offer it could find in the market. Produbanco, the local partner of Citibank, managed the cash flow between farmers, the exporters, and the FTFCC. Root Capital-financed FTFCC granted FEDECADE cooperatives and associations the flexibility to draft weekly loans, based on estimates of cocoa local availability. These week-by-week loans allowed the stock centers to pay farmers in cash, which was necessary if they were to remain competitive. Root Capital's loan repayment was guaranteed by the FTFCC structure, which collected revenue from FEDECADE's cocoa exports to Europe or US clients (Krenke 2004).

From 2004 to 2007, FEDECADE's commercialization system enjoyed a period of rapid growth because of the availability of low-interest credit, previous investments in infrastructure and training, the ability to source Organic, Fairtrade and Rainforest Alliance certified cocoa beans, and strategic NGO and IGO mediated relationships with 
chocolate manufacturers such as Hoja Verde (Ecuador), ICAM (Italy), Kraft (U.S.), Vivani (Germany), Vintage (US), and with cocoa exporters COFINA and CAFIESA. Using FCFCC capital, FEDECADE's stock centers were able to process higher amounts of cocoa beans, from 17,081 $\mathrm{kg}$ of beans per stock center ( 2 centers for $34,162 \mathrm{~kg}$ overall) in 2003 to a maximum of 52,267 kg per stock center in $2007(261,339 \mathrm{~kg}$ overall).

However, in 2008 the stock centers saw a fall to slightly over 2004 levels, with $24,734 \mathrm{~kg}$ of cocoa processed in each of the stock centers involved $(74,204 \mathrm{~kg}$ of cocoa overall). This fall was caused by several factors. First, cocoa international prices changed rapidly. Second, FEDECADE lost clients when some chocolate makers opted to substitute fine-certified cocoa for cheaper alternatives.

The year of 2008 saw drastic changes in the price of cocoa. The ICCO statistics show that prices went from US\$ 3021.76 per MT (US\$ 3.02 per kg) in June of 2008 to a low of US\$2067.72 per MT (US\$2.06 per kg) in December of that year. This downfall implied that FEDECADE's stock centers were buying conventional cocoa that they would later sell at loss. The managers of some stock centers opted for suspending commercialization for a "a week or two, to see if the prices stabilized" (Anonymous farmer, NUC, Dec 2009). The wait-and-see strategy minimized losses, but reduced the volume of transactions - thus the drastic fall on the amount of cocoa processed.

The market for premium cocoa beans from FEDECADE (Organic and Rainforest Alliance) was unfavorably affected by higher prices. Chocolate manufacturers became reluctant to stock value-added fine certified cocoa. Some manufacturers discontinued fine chocolate products (i.e. Hersheys' Grand Reserve); others substituted extra-premium 
certified fine cocoa for cheaper alternatives, or fall back into chocolate lines made with a mixture of fine and bulk cocoa.

The market for Rainforest Alliance cocoa beans shows how this substitution occurs and how it affects producers of fine cocoa. In 2006 and 2007 Kraft Food Inc. was an important FEDECADE client—buying several MT of RA certified fine cocoa. In 2007 Kraft diversified its suppliers to include plantations in Ivory Coast (Africa) that Rainforest Alliance had recently certified. The supply of Ivory Coast Rainforest Alliance certified grew cocoa rapidly, as farmers joined a project financed by a partnership between Kraft, GTZ, USAID and others (among them the cocoa trader Armajaro ${ }^{32}$ ) (Staff $2007)^{33}$. In 2008, Kraft did not source RA certified cocoa from FEDECADE, and other Ecuadorian farmer's organizations that had been supplying cocoa for this company (i.e., Aroma Amazonico). Felipe Noboa, then CYD's project director for the Kraft-GTZ project, mentioned that Kraft withdrawal was in part because of quality issues - the batches of cocoa it was receiving were irregular ${ }^{34}$ and that Kraft "did not really embrace the project" (Felipe Noboa, phone interview with author, September 2010).

\footnotetext{
${ }^{32}$ In 2010, Armajaro's business tactics became a subject of controversy in cocoa trading circles. In 2010 , this company managed to stock $7 \%$ of the worldwide supply of cocoa beans; this behavior was denounced as one of the causes that drove cocoa prices to an historical high. According to a N.Y. Times article, Armanjaro also bid heavily in cocoa stock futures, and has been accused of "intentionally" manipulating the price of cocoa beans (Werdigier and Creswell 2010).

${ }^{33}$ The Ivory Coast RA-certified list of suppliers grew from 355 farmers in January of 2007 to 2039 farmers in Fall of 2009 (Hahn and Vogel 2009).

${ }^{34}$ A fact that is not surprising given Kraft was sourcing cocoa from Western and Eastern Ecuador.
} 
Rainforest Alliance, in a report on "Overseas Demand for Ecuadorian Cocoa" done under contract for the U.S.-based Chemonics, Inc. for the U.S. AID's Sustainable Forest and Coast Initiative, concludes that the "GTZ/Kraft public private partnership" shows that "certification alone is not enough to guarantee sustained access to premium markets" given that not all the producers groups recruited for this initiative were able to meet Kraft's quality criteria. Rainforest Alliance also reported that Kraft would not buy more cocoa from Ecuador until their stocks became depleted (Rainforest Alliance 2009:19).

The demand for Fair Trade-Organic cocoa held well, and FEDECADE increased its output of this double-certified beans from $29500 \mathrm{~kg}$ in 2007 (11\% of its 2007 output of $261339 \mathrm{~kg}$ ) to $56236 \mathrm{~kg}$ in $2008(75.78 \%$ of its 2008 output of 74,204 kg). However, the rise on FT/Organic output was not enough to compensate for losing the RA and 'plain' Organic markets. Thus, while in 2007 the stock centers generated an overall profit of US\$ 16146.66, in 2008 it operation generated profits of just US\$ 492.20.

In 2009, as a response to international credit restrictions and what they saw as "chaos in the international cocoa prices" (William Foote, phone interview with author, April 2010), Root Capital asked FEDECADE to secure a future sales cocoa contract before granting a loan for $60 \%$ share of the value of the crop (Christian Pineda, interview with author, September 2009; William Foote, phone interview with author, April 2010). Future sales contracts are a standard requirement on Root's loans that had been waived previously. However, the cocoa market conditions made Root "less confident" of FEDECADE's ability to find markets (William Foote, phone interview with author, 2010). Indeed, this condition was not met by FEDECADE. Although from June of 2009 
to December of 2009 FEDECADE's was avidly looking for a viable commercialization partner it found that the premiums offered for even multi-certified cocoa did not cover even the stock centers cocoa processing expenses. For example, while from 2005 to 2007 FEDECADE secured an average premium of US\$405 per MT (US\$0.4 per kg), in 2009 it received an offer with a premium of US\$22 per MT (US\$ 0.02 per $\mathrm{kg}$ ), which was not enough to cover post-harvest and export costs (Christian Pineda, interview with author, September 2009). After stocking cocoa at record prices during 2008, buyers were trying to pay less. This is a strategy to average the values of their existing holdings. Under these conditions, FEDECADE's General Assembly decided that it was not possible to commercialize cocoa. The Assembly also released FEDECADE's associations so each could negotiate deals with other commercialization schemes ${ }^{35}$.

\section{The [unexpected] results of development projects}

The results of the evaluation of FEDECADE commercialization system (FCS) are shown in Table 2 and 3. The FCS transferred revenues for farmers in two ways: as members of a cooperative or association who shared on the profits and premiums of the commercialization, and as individuals who received a higher price for their product.

With regard to the first method of revenue generation, FEDECADE data shows that from 2003 to 2008 the commercialization system generated profits for US\$ 93,374.08 for the eight cooperatives and associations involved (see table 3). However, FEDECADE's strategy of delegating day-to-day tasks to each association's administration (namely their commercialization committees) resulted in varied financial

${ }^{35}$ In 2010, LFL and CAM secured cocoa contracts with UROCAL. 
performance: some of the committees became adept at generating profits, others struggled to stay even and some turned net losses (see Table 4 and Figure 3). Overall, the stock centers were profitable only $62 \%$ of the time they operated. Gross profit and loss margin $(\mathrm{GPLM}=(\mathrm{P} \& \mathrm{~L} * 100) /$ Total Sales $)$ vary widely by years and associations/cooperatives; on average, the stock centers GPLM was 3.99\% per year (SD $7.6 \%$ ), with a maximum profit of $23.75 \%$ GPLM recorded for 3DO in 2005, and a record loss of $8.35 \%$ GPLM for CAM in 2008. The FEDECADE attempted to regulate the management of the stock centers by developing and implementing internal regulations of increasing complexity. ${ }^{36}$ The regulations nevertheless failed to guarantee the profitability of the stock centers. Current and former committee members I interviewed coincide that "learning the cocoa trade" required of them to learn to judge the quality of cocoa in a way that outsmarted the exporters "calificador" ${ }^{37}$ when buying fermented and dried cocoa beans (2003-2004) (Anonymous farmer, interview with author, 6DJ). However, they also said that they had to use the same skills to judge the cocoa of their fellow associatesthus becoming what producers nicknamed "our own middleman" (Anonymous farmer, interview with author, 6DJ). Buying wet cocoa was simpler, given that 'fairness' involved experimentation that lead to a empirical/objective conversion rate applied when

\footnotetext{
${ }^{36}$ Thus, the first commercialization experiments were run under a short set of written rules (119 words) (Desarrollo 2000); the 2005 CYD-edited "Guide for commercialization" amounted to 1262 words (Desarrollo 2005), and the 2006 FEDECADE's "Commercialization norms" totaled 2513 words.

${ }^{37}$ A "calificador" is a specially trained employee that is in charge of evaluating the quality of each lot of cocoa beans. This is a critical function, given that these people strive for judging the quality of cocoa on the spot, using little or none equipment to assess the worthiness (in quality terms) of a cocoa lot in a way that secures profits for the exporter without disgruntling cocoa sellers.
} 
buying wet raw cocoa for post harvest processing by the association. Stock centers found that they needed to adjust their conversion rates for summer or winter, and by location: the conversion rate for "cacao de playa" (0-100 meters above sea level) was not the same as for "cacao de monte" (100-400 meter above sea level) (Anonymous farmer, interview with author, NUC). The main issue with this need for learning and experimentation is that it remained a localized activity: this hard-won expertise was not institutionalized and remained part of individuals' experience, which mean that each stock center crew had to "learn" by themselves every time they were replaced.

The second way in which the commercialization transferred resources to farmers was by paying a higher gate price than was paid in the local market. On average, I estimated that from 2003 to 2008 FEDECADE's average gate price was US\$405 per MT (US\$ 0.405 per kg) higher than the market gate price. After its six years run, FEDECADE had transferred US\$ 418,378 to the farmers that sold cocoa to the stock centers, for an average of US\$69,729 per year. The investment by international donors, of US\$ 1,436,738 according to CYD data, would have been recovered if the commercialization scheme had worked for another fourteen years.

The commercialization system of FEDECADE did benefit farmers that were not part of a FEDECADE's affiliated association. First, the stock centers bought cocoa from these farmers, under the "commercial partners" umbrella. This cocoa—which was not certified under any scheme - was sold directly to the exporters as "cacao convencional" (non-certified, without premium), although the stock centers' processing costs were the same as for 'certified' cocoa. However, the stock centers paid a higher than average price to these farmers, thus this trade segment—which FEDECADE saw as fulfilling its social 
role — generated marginal profits (at best) and losses in some cases. Second, the stock centers - with their direct links to exporters and chocolate manufacturers - became regional price setters, against whom local intermediaries had to compete in order to remain in the business. For instance, Justo Paucar, who was the President of the 3DO association for the 2004-2005 period remembers that "after the stock centers opened, the middleman had to pay twice as much for a $\mathrm{can}^{38}$ of cocoa as before: they paid up to $\$ 16$ per can, when before they were paying just about $\$ 8$." He said that [the mood at the stock center] "was like a party," with people coming from everywhere and taking turns to sell" (Justo Paucar, interview with the author, Rio Bonito/3 de Octubre, October 2009). Farmers remember these days fondly; in the 2009 survey, $29 \%$ of FEDECADE farmers mentioned that selling fermented and dried cocoa to the stock centers was advantageous to their household income even though the stock centers had been closed for at least one year $^{39}$. In this sense, the FEDECADE commercialization system was successful at challenging the intermediaries mediated commodity chain.

Even at the peak of FEDECADE's operation, some intermediaries remained in the area. Most of them did so because they were the only source of out-of-cocoa-season loans for farmers. Farmers developed a split share approach towards the stock centers and the intermediaries. They sold a share of their crop to the stock centers attracted by the overall higher price, but designated another share to the intermediaries because of this loan-

\footnotetext{
${ }^{38}$ A "can" (Lata in Espanish) is a volumetric measure for wet cacao. Roughly, 6 cans of wet cacao yield $45 \mathrm{~kg}$ of dry beans (1 quintal or 100 pounds).

${ }^{39}$ On the other hand, in my 2009 survey just $29 \%$ of the farmers reported that they were fermenting cocoa, given that the middlemen did not 'pay' extra for this labor.
} 
granting role (Pedro Flores and Domingo Mendoza, interview with author, November 2009). These cash-for-crop loans are informal arrangements in which the farmer pays for the loan by selling his or her cocoa to the loan makers. Although these loans are nominally interest-free, middlemen extract profits out of negotiating price, and discounting weight to remain profitable ("les da machete en peso y precio," [cuts down the price and plays with the weight], in the words of Pedro Flores and Domingo Mendoza, 2009). The CYD and FEDECADE were aware of farmers' dependence of these paid-with-crop loans, but after the collapse of 6DJ commercialization (where internally-issued loans that were not repaid) these institutions shunned granting loans to farmers (FEDECADE 2004a; FEDECADE 2004b; Desarrollo 2005). By 2009, intermediaries in the FEDECADE area were operating as they were before the projects started $^{40}$

On the down side, FEDECADE's incursion on cocoa exporting also exposed the associations to the risks of price-volatility. Stocking cocoa in a period where prices are going down could easily wipe out the profits of a year, because the price of sale could be lower than the price the association had paid for the cocoa (Anonymous farmer, NUC, 2009). The price paid to the unaffiliated "socios comerciales" was another source of internal discord. The stock centers paid the same price for the "cacao convencional" (non-certified) of the unaffiliated farmers as for the "cacao convencional" of the affiliated ones. Some farmers thought that there was a level of unfairness (towards the association's farmers) in granting a fair price to individuals that did not cope with the burdens of

${ }^{40}$ See Chapter 4 for a description of FEDECADE farmers in 2009. 
belonging to the associations (i.e., going to meetings, working in the association centers, etc) (Anonymous farmer, NUC, 2009). Other farmers were concerned because "cacao convencional" did not receive any premium, but processing costs were the same (Anonymous farmer, NUC, 2009). My informant concluded that trading "conventional" presented diminishing returns to the stock center, given that their processing costs for non-premium or premium cacao were the same.

The administrative tasks of FEDECADE were also increasingly driven by the needs of being certified. Each certification system required a dedicated database of certified farmers, among other records. Also, the FEDECADE assumed the daunting task of training farmers in these programs, in conditions where $68.9 \%$ of the farmers had just an elementary school education and $8.7 \%$ were not able to write or read at all (ECU-B7 1997). Some of these producers had to be aware and comply with the "internal" regulations for the organic certification (4100 words) (FEDECADE 2004b), the Rainforest Alliance certification (6200 words) (FEDECADE 2004a), and/or Fair Trade certification (a brief one page document).

Some stock center personnel reported that "certification traceability requirements" were in conflict with their "post-harvest management/quality procedures" (Anonymous farmer, NUC, 2009). The conflict was born of the fact that cocoa fermentation (a critical step to achieve high quality beans) requires a large wet cocoa mass (at least $100 \mathrm{~kg}$ ) but certification requirements asked for separate processing for smaller batches (Anonymous farmer, NUC, 2009). Thus, the stock centers were faced with contradictory demands that implied sacrificing quality (a selling point) in favor of a certification requirement (traceability). 
The operation of the commercialization systems was another point of contention for the associations. In two cases, changes in an association's directive resulted in those association dropping out of the commercialization system. In the case of $6 \mathrm{DJ}$, the previous directive had granted loans to farmers to secure cocoa in the face of loangranting by intermediaries. A faction of the cooperative's farmers ran for elections under the argument that these "debts" should be covered using the cooperative's commercialization profits. When this group won, it canceled individual farmers' debts. The commercialization fund was depleted, and it closed operations. The response of CYD and FEDECADE to this problem was to ban the diversion of funds from commercialization to other uses. This norm was generally accepted until 2008, when the NUC directive used part of its funds to acquire a lot to build a police force Immediate Response Center (Puesto de Auxilio Inmediato, PAI) ${ }^{41}$. This was done because early that year several NUC farmers had been victims of violent crime (armed robbery) in their own homes. In this case, FEDECADE considered that this diversion of funds was an internal matter.

In a second example of internal struggle, FEDECADE's internal norms specified that the commercialization committee was made up of each Association's elected President and Treasurer. Thus, the "know-how" of an incumbent directive could be lost if they were not reelected. This was the case of 3DO, which in 2005 generated a GPLM of

\footnotetext{
${ }^{41}$ Ecuador Police' is chronically underfunded, so it has limited ability to build new infrastructure. In order to house troopers in a place, the community has to build (from scratch) their own PAI. Once the PAI is build, the police normally assign a few troopers and a vehicle to it. In NUC case, the main benefit of a PAI was that they believed that police response time will go down to five to ten minutes (from the 30 minutes or more that it took police to come from Naranjal).
} 
24\%. A faction within the association argued (among other points) that this margin was too high, and that profits should be transferred to the farmers instead of the stock center fund. This group won the early 2006 election. However, in 2006, under the new directive 3DO stock center suffered a 3\% loss of the total sales. In 2007, this stock center turned a profit of $4 \%$ of the total sales. In 2008, this association did not operate at all (3DO farmers sold their cocoa to other FEDECADE centers) (Justo Paucar, interview with the author, Rio Bonito/3 de Octubre, October 2009).

\section{Lessons learned: shades of gray in a development program}

In summary, from 1995 to 2008 the farmers affiliated with FEDECADE were the recipients of a loosely coordinated multi-year development program directed by an Ecuadorian NGO, supported by donations from a heterogeneous set of international donors, and commercial loans from a socially-aware investment fund. This program's overall goal was to increase the income of farmers planting shade-grown Nacional cocoa, an endemic Ecuadorian variety that was deemed endangered by technological and economic developments. In 2009, after 6 years of operation, FEDECADE's commercialization system ceased to operate. The project had achieved its generic goal of increasing cocoa output per unit of area, and in increasing farmer's income by creating an alternative commercialization system that transferred revenues from cocoa exports

directly to the farmers. This alternative commodity chain gave farmers an attractive outlet for their products, and forced intermediaries to rationalize their profitability. By leveraging FEDECADE's activities with low-interest international capital, CYD project acted as an agent of change at the local market and thus apparently harnessed the forces 
of capitalism in benefit of cocoa farmers. However, in 2009, a series of internal and external factors forced FEDECADE to stop its activity.

This failure can be explained in several ways. From a structural point of view, even the best-financed multi-certified small farmers association is at a clear disadvantage in relation to the power of multinational corporations. The collapse of FEDECADE's RA certified cocoa market, after Kraft Foods Inc. started to source RA cocoa from West Africa, shows how the worldwide race for achieving certification actually benefits multinational companies which have the ability to source commodities from the lowest cost (or most convenient) supplier. Certification-based alternative trade systems, which were heralded as the great and promising alternative to the multinational dominated commodity chain, have become a victim of their own success. Quoting an anonymous respondent to a Rainforest Alliance conducted survey: "the price benefit of certification only works if demand outstrips supply" (Rainforest Alliance 2009: 20). With producers all over the world vying for a "label" to give them a market edge, FEDECADE's experience suggest that certified products have become just another commodity subject to cycles driven by supply and demand. Furthermore, when fine cocoa becomes too expensive, chocolate makers substitute fine cocoa for cheaper bulk cocoa and spices-as they have been doing since Venezuelan and Mexican "Criollos" were substituted with the less-well regarded Ecuadorian Nacional and when Nacional was substituted with West Africa and Brazil Forasteros (Alden 1976).

Questions can also be raised about FEDECADE's approach towards commercialization, which called for selling cocoa to the highest bidder. As advertised by CYD, this highest-bidder-approach generated revenues in the short term. However, in 
2009 FEDECADE was not able to secure a purchase order because it lacked a strategic partner. Meanwhile, other FEDECADE-like organizations continued to work, favored by their long-term relationship with one buyer (i.e., UNOCACE with the French firm Kaoka (Interview with Freddy Cabello, UNOCACE manager, Quito, December 2009).

FEDECADE's example also raises doubts about the viability of pairing developing-country organizations with global financial partners. In these relationships, the burden of risk is carried by those in developing economies. When Root deemed FEDECADE's cocoa business was “too risky," it pulled out (Foote, 2010). FEDECADE was not able to find other financer for the FTFCC, which led to its inability to operate in 2009. While external factors - the worldwide 2007-2008 economic crisis-are the underlying causes of Root's credit restriction, this illustrates the power differential that exists between financers and producers, and certainly points to the vulnerability of the developing country partners in these alliances. Finally, FEDECADE's experience also shows the failings of leveraging development on what remains a commodity, subject to the whims of the international markets. Cocoa prices and stocks have been fluctuating wildly in the global markets, reaching historical heights only to fall vertiginously. The behavior of Northern stockholders, from small investors to the Armajaro Hedge Fund, have deep repercussions on the livelihoods (and hopes) of commodity-producing farmers in the developing world. Thus, successful commodity-based development programs exacerbate rural communities' exposure to these risks.

Internally, the uneven performances of FEDECADE's stock centers highlight the perils of imposing a for-profit capitalistic enterprise on top of locally existing socialcapital-based structures. FEDECADE's associations and cooperatives respond to the 
concerns of their constituents, with directives elected by a majority of the votes. On the other hand, the stock centers were thought to behave as a community-based enterprise, generating profits for the benefit of the community. FEDECADE's answer for the challenge of sustaining internal governance for a revenue-generating venturedelegating the stock center management to each community elected directive-responded to a belief in self-determination at the association level. However, as the case of 6DJ illustrates, the stock centers became hostages of internal politics, with groups within the Association bidding for control of the source of revenue (or rents from debt forgiveness). The second failing of FEDECADE's answer was that the hard-won human capital (as experience gained by working in commercialization) was lost in democratic elections. It can be argued that some of the stock center failures could have been avoided if its administration would have been set up with some degree of independence from the associations' directives. From one perspective, CYD's timid attempt to push FEDECADE towards capitalism was certainly insufficient. From the other, these findings also suggest an ongoing struggle for defining terms and conditions under which development projects operate. On one side stand the values and goals of the NGOs and their international counterparts; on the other side, stand the values and goals of the farmers. While there are points of commonality among these voices, it is worth remembering that the funders, co-opted by a prodding NGO intermediary, decide which projects are financed. Local failures - such as that of FEDECADE - are the result of imposing a problem-solving agenda, which does not incorporate local viewpoints. On the other hand, these results show structural failures in the conceptualization of alternative trade. As alternative trade captures a larger share of production, it becomes 
commoditized; thus, these efforts become a victim of their own success. FEDECADE's Fair Trade experience is also instructive, because although this market held it was not large enough to keep the system operating. Also, basic business management conceptssuch as profitability, revenue generation, and how to achieve economies of scale-seem to have been lacking from the technological expertise transferred to FEDECADE.

Finally, the results of the survey indicate that CYD and international donors have not succeeded at convincing farmers to remain wedded to Nacional. Only one out of the 100 farmers I interviewed replanted his farm with Nacional, and that was done eight years ago. Meanwhile, in the last seven years (within the period of execution of the projects) 38 farmers had renovated their plantations using $\mathrm{CCN}-51$ (out of 100). These data suggest that even when the stock centers paid premium prices for Nacional, farmers were voicing their choice for agricultural intensification by planting CCN-51. Farmers' assessment was probably guided by three facts: $\mathrm{CCN}-51$ yields three times as much cocoa per unit of area as Nacional; the market gate price for both varieties remains the same, and finally, trading CCN-51 does not require fulfilling strict and contradictory regulations at all, and can be conducted even if stock centers are closed. 

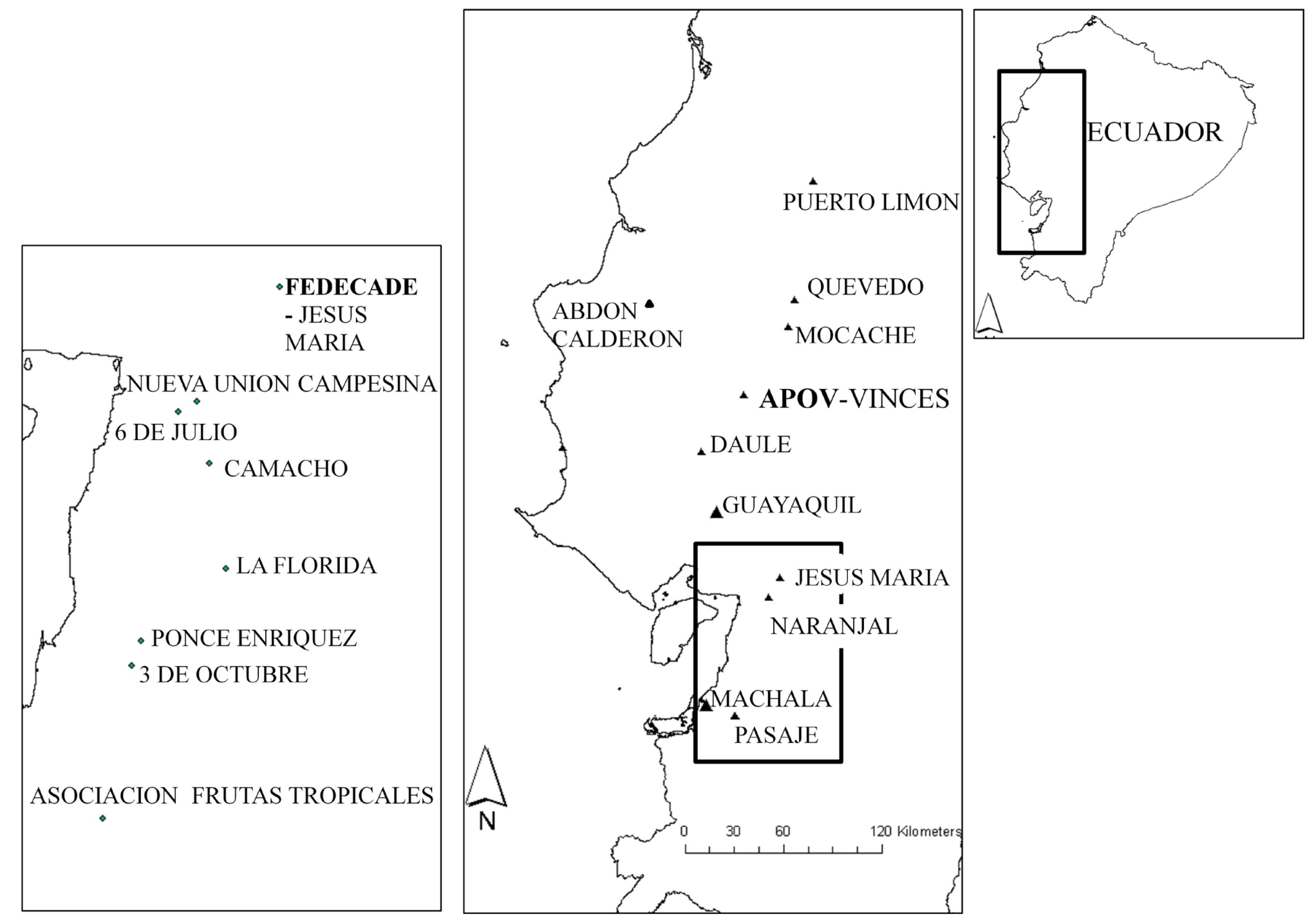

Figure 1. Area of Study. Ecuador, the Western lowlands (Costa), APOV and FEDECADE associations and cooperatives. 


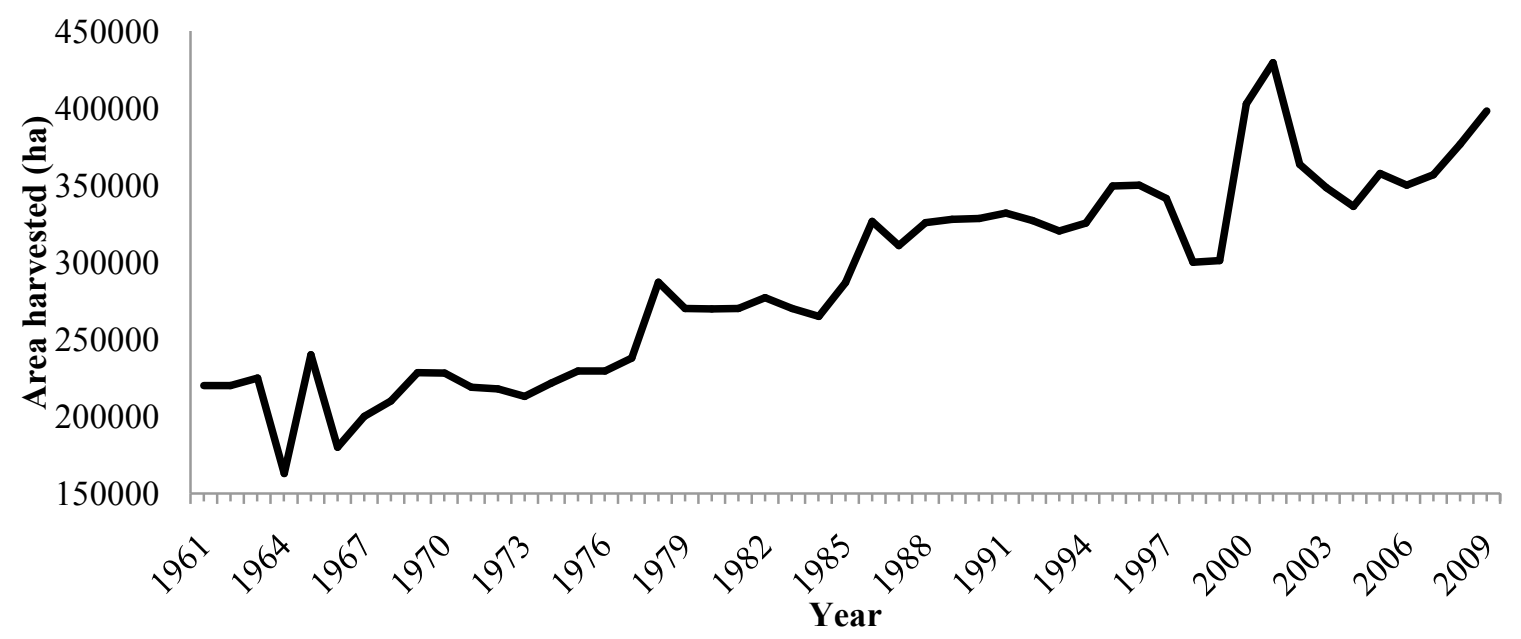

(a) Area harvested by year (ha/year)

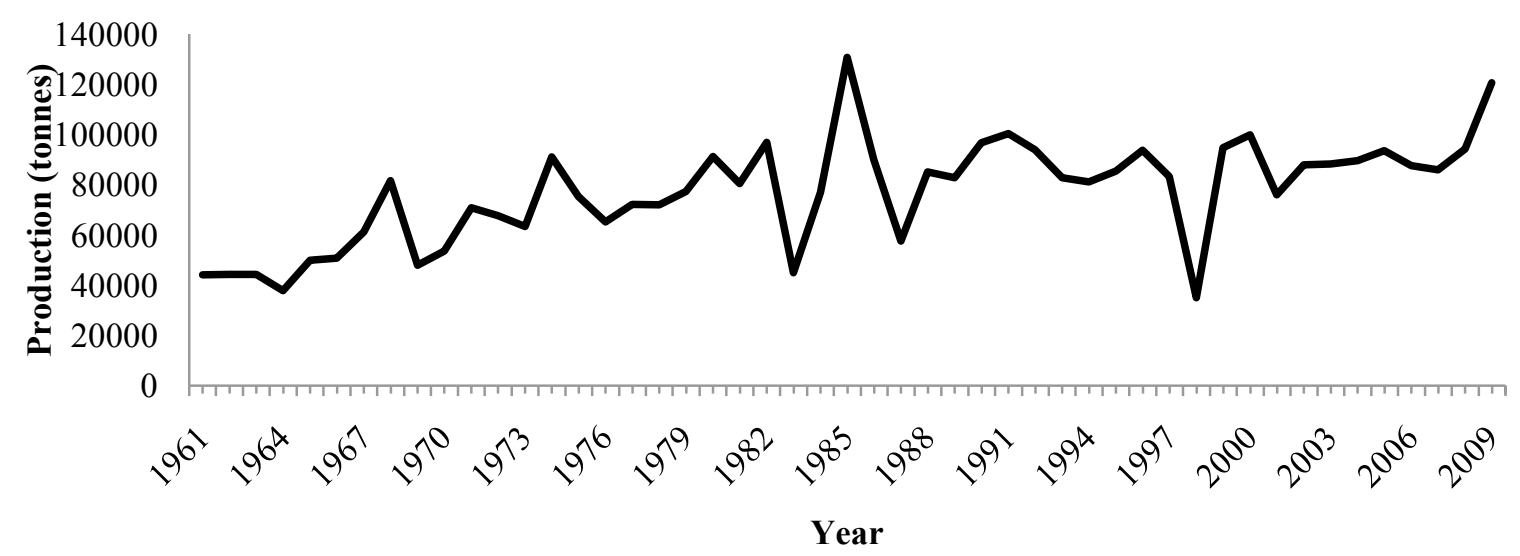

(b) Production by year (tonnes/year)

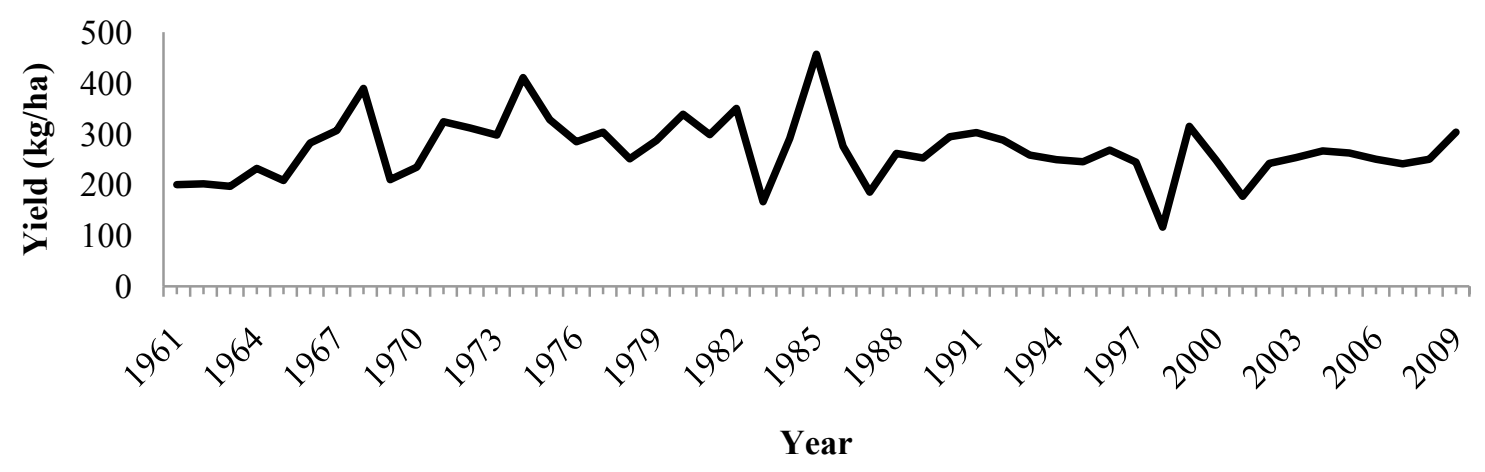

(c)Yield by area and year $(\mathrm{kg} / \mathrm{ha}$ year)

Figure 2. Ecuadorian cocoa production statistics, 1961-2009. (a) Area harvested (ha/year). (b) Production by year (tonnes/year). (c) Yield by area (kg/ha/year). Source: FAOSTAT 2010; ANECACAO 2010. 


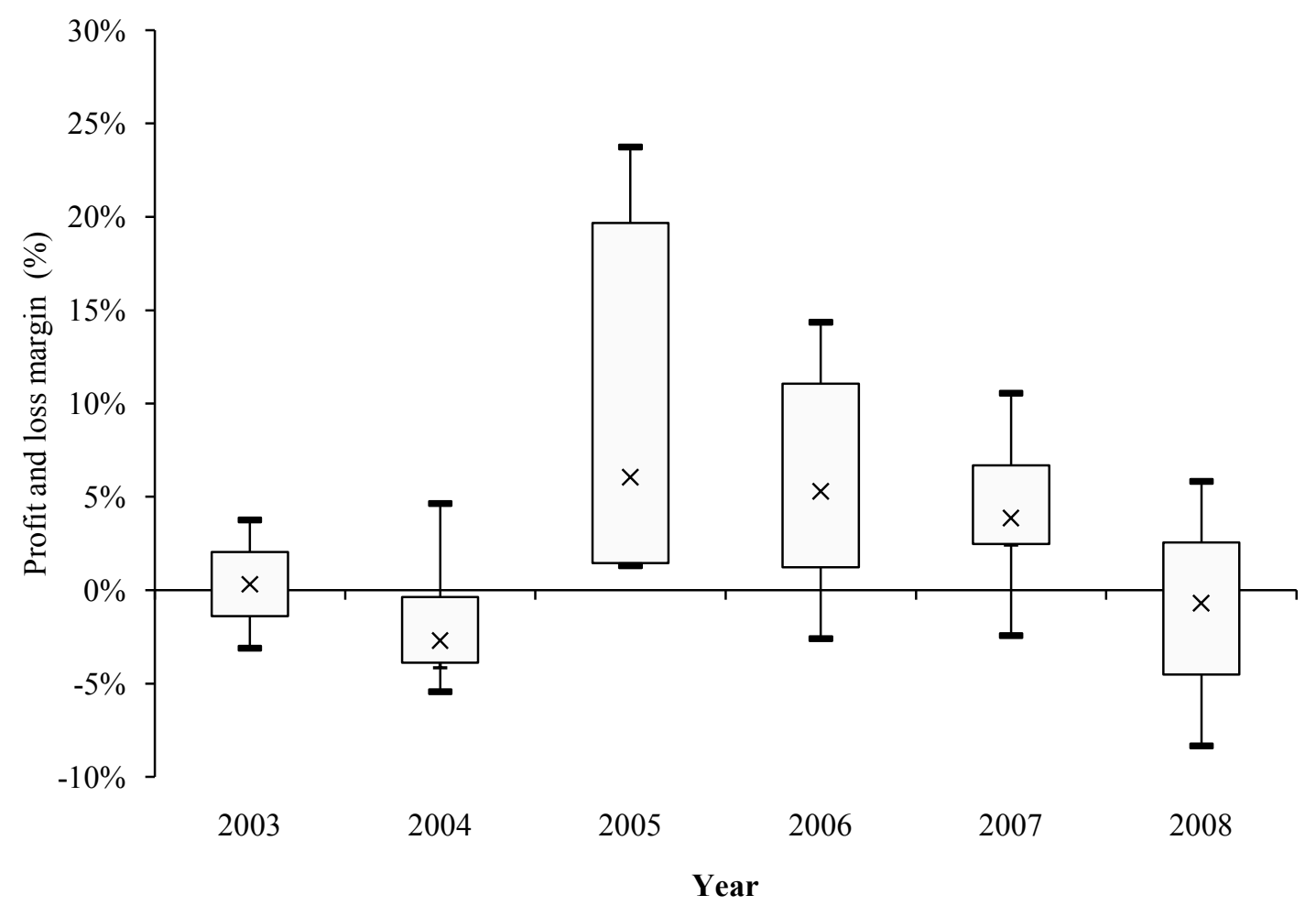

Figure 3. FEDECADE profit and loss margin as percentage of sales box plot for all associations/cooperatives by year, where $\times$ marks average profit and loss margin, box is represents first and third quartile, and error bars show inter-associations variability. 
Table 1. Investing in FEDECADE: Year of execution, project title, donors, and project amounts in US\$.

\begin{tabular}{|c|c|c|c|c|c|c|}
\hline Year & Project title & Donor & $\begin{array}{l}\text { Country of } \\
\text { origin }\end{array}$ & Donor $(\$)$ & $\begin{array}{l}\text { Local } \\
\text { counterparts } \\
(\$) \dagger\end{array}$ & $\begin{array}{l}\text { TOTAL } \\
\text { PROJECT } \\
(\$)\end{array}$ \\
\hline 1996 & Establishment of cocoa certification system & $\begin{array}{l}\text { Earth Love } \\
\text { Fund }\end{array}$ & UK & $\$ 5,000$ & $\$ 2,500$ & $\$ 7,500$ \\
\hline $\begin{array}{l}1996- \\
1998\end{array}$ & $\begin{array}{l}\text { Development of cocoa commercialization } \\
\text { system and creation of ecological } \\
\text { certification norms FOES-154E [152] }\end{array}$ & $\begin{array}{l}\text { Ecuadorian- } \\
\text { Swiss Fund }\end{array}$ & Switzerland & $\$ 81,538^{*}$ & $\$ 25,000^{*}$ & $\$ 106,538$ \\
\hline $\begin{array}{l}1999- \\
2000\end{array}$ & $\begin{array}{l}\text { Construction of a cocoa stock center and a } \\
\text { cocoa commercialization business } \\
\text { INTERMON } 3125\end{array}$ & $\begin{array}{l}\text { INTERMON } \\
3125\end{array}$ & Spain & $\$ 125,000^{*}$ & $\$ 5,000^{*}$ & $\$ 130,000$ \\
\hline $\begin{array}{l}1999- \\
2001\end{array}$ & $\begin{array}{l}\text { Cacao's production and commercialization } \\
\text { improvement AG- } 0528\end{array}$ & $\begin{array}{l}\text { Ecuadorian } \\
\text { Canadian } \\
\text { Fund }\end{array}$ & Canada & $\$ 307,500$ & $\$ 243,600$ & $\$ 551,100$ \\
\hline $\begin{array}{l}2001- \\
2004\end{array}$ & $\begin{array}{l}\text { Production and commercialization of fine } \\
\text { and aroma cacao in Ecuador's South } \\
\text { Western Region AG- } 0622\end{array}$ & $\begin{array}{l}\text { Ecuadorian } \\
\text { Canadian } \\
\text { Fund }\end{array}$ & Canada & $\$ 348,700$ & $\$ 319,680$ & $\$ 668,380$ \\
\hline $\begin{array}{l}2005- \\
2006\end{array}$ & $\begin{array}{l}\text { Establishment of certified cocoa chain of } \\
\text { custody }\end{array}$ & $\begin{array}{l}\text { Overbrook } \\
\text { Foundation }\end{array}$ & US & $\$ 40,000$ & $\$ 12,500$ & $\$ 52,500$ \\
\hline $\begin{array}{l}2006- \\
2007\end{array}$ & Sustainable cocoa and livelihoods & $\begin{array}{l}\text { Overbrook } \\
\text { Foundation }\end{array}$ & US & $\$ 20,000$ & $\$ 30,000$ & $\$ 50,000$ \\
\hline $\begin{array}{l}2006- \\
2008\end{array}$ & $\begin{array}{l}\text { Expand and create production and } \\
\text { management structures and competencies of } \\
1500 \text { small scale cocoa producers in order } \\
\text { to increase production and exportation of } \\
\text { Rainforest Alliance certified cocoa from } \\
\text { Ecuador }\end{array}$ & $\begin{array}{l}\text { Kraft-RA- } \\
\text { Goldamn- } \\
\text { DOEN }\end{array}$ & $\begin{array}{l}\text { Germany, } \\
\text { US, } \\
\text { Netherland }\end{array}$ & $\$ 235,000$ & $\$ 200,000$ & $\$ 435,000$ \\
\hline
\end{tabular}


Table 1. (continued)

\begin{tabular}{|c|c|c|c|c|c|c|}
\hline Year & Project title & Donor & $\begin{array}{l}\text { Country of } \\
\text { origin }\end{array}$ & Donor (\$) & $\begin{array}{l}\text { Local } \\
\text { counterparts } \\
(\$) \dagger\end{array}$ & $\begin{array}{l}\text { TOTAL } \\
\text { PROJECT } \\
(\$)\end{array}$ \\
\hline $\begin{array}{l}2006- \\
2008\end{array}$ & $\begin{array}{l}\text { Expand and create production and } \\
\text { management structures and competencies } \\
\text { of } 1500 \text { small scale cocoa producers in } \\
\text { order to increase production and } \\
\text { exportation of Rainforest Alliance } \\
\text { certified cocoa from Ecuador }\end{array}$ & $\begin{array}{l}\text { Deutsche } \\
\text { Gesellschaft für } \\
\text { Technische } \\
\text { Zusammenarbeit } \\
\text { (GTZ) }\end{array}$ & Germany & $\$ 189,000$ & $\$ 200,000$ & $\$ 389,000$ \\
\hline
\end{tabular}

$\uparrow$ This amount was the cash value of local contributions to the projects, donated by FEDECADE's members (land and work), FEDECADE's local NGO partner (at the time, Conservacion y Desarrollo), or by other agencies. ${ }^{*}$ Estimated value, given that amounts were originally reported in sucres (S/.) (by 1999, Ecuador adopted US\$ as a currency, to the conversion factor of $\mathrm{US} \$ 1=\mathrm{S} / .25000)$.

Source: Archives of Conservacion y Desarollo (Quito, Ecuador) (2010); Archives of FEDECADE (Jesus Maria, Ecuador) (2009). 
Table 2. Average commercialization parameters for FEDECADE commercialization system, 2003 to 2007.

\begin{tabular}{|c|c|c|c|c|c|c|}
\hline \multirow[b]{2}{*}{ Parameters } & \multicolumn{6}{|c|}{ Years } \\
\hline & 2003 & 2004 & 2005 & 2006 & 2007 & 2008 \\
\hline A Associations/Coops (n) & 2 & 4 & 5 & 6 & 5 & 3 \\
\hline B Assoc. gate price (AGP) (US\$ per kg) ${ }^{\dagger}$ & 1.29 & 1.29 & 1.53 & 1.81 & 2.05 & 2.60 \\
\hline C Assoc. sale price (ASP) (US\$ per kg) ${ }^{\dagger}$ & 1.37 & 1.36 & 1.91 & 2.20 & 2.56 & 2.97 \\
\hline D FOB price (US\$ per kg) & 1.71 & 1.45 & 1.45 & 1.61 & 2.38 & 2.50 \\
\hline E Market gate price (MGP) (US\$ per kg) ${ }^{\dagger \dagger}$ & 1.17 & 0.96 & 1.03 & 1.27 & 1.69 & 2.02 \\
\hline F Cocoa bought $(\mathrm{kg})$ & 34965.29 & 112675.28 & 206979.15 & 241099.32 & 270175.94 & 79719.73 \\
\hline G Cocoa sold (kg) & 34162.78 & 107012.70 & 209740.91 & 227097.05 & 261339.68 & 74204.54 \\
\hline H Management losses ( $\%$ of D) & $3.24 \%$ & $3.04 \%$ & $-0.97 \%$ & $2.58 \%$ & $4.82 \%$ & $2.50 \%$ \\
\hline I Management cost (US\$ per kg) & 0.03 & 0.04 & 0.19 & 0.16 & 0.33 & 0.22 \\
\hline
\end{tabular}


Table 3. Expenses; sales; profit and loss, and estimated revenue (in US\$) for farmers for FEDECADE commercialization system, 2003 to 2007.

\begin{tabular}{|c|c|c|c|c|c|c|c|}
\hline \multirow[b]{2}{*}{ Commercialization profit and loss } & \multicolumn{6}{|c|}{ Years } & \multirow[b]{2}{*}{ Total } \\
\hline & 2003 & 2004 & 2005 & 2006 & 2007 & 2008 & \\
\hline J Expenses $\left[\left(B^{*} F\right)+\left(I^{*} G\right)\right](U S \$)$ & 46536.26 & 147555.56 & 362657.01 & 459686.76 & 646773.29 & 216760.61 & 1879969.48 \\
\hline K Sales $\left(C^{*} G\right)(U S \$)$ & 47422.41 & 145404.09 & 400313.99 & 500030.31 & 662919.95 & 217252.81 & 1973343.56 \\
\hline L Profit \& loss (P\&L) (US\$) & 886.15 & -2151.47 & 37656.98 & 40343.55 & 16146.66 & 492.20 & 93374.08 \\
\hline M P\&L as $\%$ sales $\left[(\mathrm{L} / \mathrm{K})^{*} 100\right]$ & $1.87 \%$ & $-1.48 \%$ & $9.41 \%$ & $8.07 \%$ & $2.44 \%$ & $0.23 \%$ & $20.53 \%$ \\
\hline
\end{tabular}

\begin{tabular}{|c|c|c|c|c|c|c|c|}
\hline \multirow[b]{2}{*}{ Revenue for farmers (estimated) } & \multicolumn{6}{|c|}{ Years } & \multirow[b]{2}{*}{ Total } \\
\hline & 2003 & 2004 & 2005 & 2006 & 2007 & 2008 & \\
\hline $\begin{array}{l}\text { N Farmer's sales at AGP (B*F) } \\
\text { (US\$) }\end{array}$ & 45223.26 & 145629.62 & 315720.22 & 435639.29 & 552932.16 & 207580.96 & 1702725.51 \\
\hline $\begin{array}{l}\text { O Farmer's sales at MGP (E*F) } \\
\text { (US\$) }\end{array}$ & 40763.88 & 107872.04 & 212158.67 & 307351.17 & 455360.43 & 160840.53 & 1284346.71 \\
\hline $\begin{array}{l}\text { P Revenue (estimated) (N-O) } \\
\text { (US\$) }\end{array}$ & 4459.37 & 37757.59 & 103561.55 & 128288.12 & 97571.73 & 46740.43 & 418378.80 \\
\hline
\end{tabular}

Sources: ${ }^{\dagger}$ Archives of Fedecade 2009; ${ }^{\ddagger}$ Anecacao 2010; ${ }^{\dagger}$ 2004: Guayaquil 2004; 2005-2007: FAO (2010) gate price - US\$10; 2008: Guayaquil 2008. 
Table 4. Profit and loss margin 2003-2008 for all cooperatives and associations involved with FEDECADE commercialization system

\begin{tabular}{lrrrrrr} 
Cooperative or & \multicolumn{6}{c}{ Year } \\
\cline { 2 - 7 } Association & 2003 & 2004 & 2005 & 2006 & 2007 & 2008 \\
\hline NUC & $3.76 \%$ & $-3.37 \%$ & $6.06 \%$ & $8.30 \%$ & $-2.43 \%$ & $5.83 \%$ \\
LFL & $\bullet$ & $-2.04 \%$ & $1.31 \%$ & $14.36 \%$ & $10.55 \%$ & $-0.70 \%$ \\
CAM & $\bullet$ & $-5.44 \%$ & $19.67 \%$ & $11.97 \%$ & $6.69 \%$ & $-8.34 \%$ \\
6DJ & $-3.11 \%$ & $4.64 \%$ & $1.45 \%$ & $\dagger$ & $\dagger$ & $\dagger$ \\
3DO & $\bullet$ & $\bullet$ & $23.75 \%$ & $-2.60 \%$ & $3.87 \%$ & $\dagger$ \\
PRO & $\bullet$ & $\bullet$ & $\bullet$ & $2.31 \%$ & $\dagger$ & + \\
ROS & $\bullet$ & $\bullet$ & $\bullet$ & $0.87 \%$ & $\dagger$ & $\dagger$ \\
FRT & $\bullet$ & $\bullet$ & - & $\bullet$ & $2.48 \%$ & $\dagger$ \\
\hline
\end{tabular}

NUC: Cooperative Nueva Union Campesina; LFL: Cooperative La Florida; CAM:

Association Camacho (Luz y Guia Campesina); 6DJ: Cooperative 6 de Julio; 3DO:

Association 3 de Octubre; PRO: Association El Progreso; ROS: Association Rosalino

Ortega; FRT: Association Frutas Tropicales. Notes: • Cooperative or association was not yet incorporated to the commercialization system; $\uparrow$ coop/assoc. did not participate in any associative commercialization system; $\$$ coop/assoc. continued trading cocoa independently or by joining an associative commercialization system other than FEDECADE's. Sources: Archives of FEDECADE 2009. 


\section{REFERENCES}

Alden, Dauril. 1976. The significance of cacao production in the Amazon region during the late colonial period: an essay in comparative economic history. Proceedings of the American Philosophical Society 120(2): 103-135.

ANECACAO. 2010. Estadisticas de Exportacion de cacao por calidades. Guayaquil: Asociacion Nacional de Exportadores de Cacao. Accessed online 02/02/2010

Ashman, D. 2001. Strengthening North-South Partnerships for Sustainable Development. Nonprofit and Voluntary Sector Quarterly 30(1): 74-98.

Bingen, Jim, Alex Serrano, and Julie Howard. 2003. Linking farmers to markets different approaches to human capital development. Food Policy 28: 405-419.

Brown, Sandy, and Christy Getz. 2008. Towards domestic fair trade? Farm labor, food localism, and the 'family scale' farm. GeoJournal 73: 11-22.

Brundtland, G.H. 1987. Our common future [The Brundtland report]. World Commission on Environment and Development. Oxford; New York: Oxford University Press, 1987.

Bryant, Raymond L, and Michael K Goodman. 2004. Consuming narratives: the political ecology of 'alternative' consumption. Transactions of the Institute of British Geographers 29(3): 344-366.

Castro, Homero U. 1981. Posibilidad de creacion de una nueva variedad de cacao de fruto hexalocular por cruzamiento entre flores mutantes hexameras. Naranjal: Author. Archives of Victor Chacon Salinas. FEDECADE, Jesus Maria, 2009.

Chacon Salinas, Victor. 1983. Descripcion de los lotes de huertos de cacao sembrados con progenies de Nacionales seleccionados, conocidos como "Tengueles," en Hda. Secadal. Segun estadistica de produccion del anio 1.982. Archives of Victor Chacon Salinas. FEDECADE, Jesus Maria, 2009.

Chacon Salinas, Victor. 1986. Informe de Produccion del Cultivo de Cacao Año 1985Hacienda La Rural and Hacienda Balao Chico. Archives of Victor Chacon Salinas. FEDECADE, Jesus Maria, 2009.

Chacon Salinas, Victor. 1990. El cultivo de cacao en el Ecuador y sus definiciones, e importancia. Archives of Victor Chacon Salinas. FEDECADE, Jesus Maria, 2009.

Desarrollo, Conservacion y. 1998. Reporte de control presupuestario. Quito: Archives of Conservacion and Development 2009. 
Desarrollo, Conservacion y. 2000. Estrategia de comercializacion: Proyecto para la Creacion de un centro de acopio y una empresa de comercializacion de cacao. Proyecto INTERMON 3125. Quito: Conservacion y Desarrollo. http://www.scribd.com/doc/25358830/Estrategia-Intermon-Para-La-Creacion-deUn-Centro-de-Acopio-de-Una-Empresa-de-Comercializacion-de-Cacao-2000.

Desarrollo, Conservacion y. 2001. Presupuesto Proyecto AG-0622. Quito: Archives of Conservacion and Development 2009.

Desarrollo, Conservacion y. 2005. Manual de Procedimientos Internos para Comercialización. Quito: Archives of Conservacion and Development 2009.

ECU-B7, Proyecto. 1997. Documento del Proyecto No.22: Principales Caracteristicas de la Produccion y Mejora de la Calidad del Cacao en el Ecuador. Guayaquil: ECUB7.

Estudios, Direccion General De. 2006. Ecuador Evolución del crédito y tasas de interés Diciembre 2006 \#20. Quito: Banco Central del Ecuador. http://www.bce.fin.ec/documentos/Estadisticas/SectorMonFin/BoletinTasasIntere s/ect200612.pdf.

FAOSTAT. 2010. Production and Trade statistics. Food and Agriculture Organization. http://faostat.fao.org/ Accessed online 01/01/2010-09/20/2010

FEDECADE-Max_Havellar. 2000. FEDECADE: Federacion Nacional de Productores de Cacao del Ecuador.. Archives of FEDECADE, Jesus Maria, 2009.

FEDECADE. 2004. REGLAMENTO PARA LA PRODUCCIÓN DE CACAO CON LA CERTIFICACIÓN RAINFOREST ALLIANCE DE LA FEDERACION Nacional DE PRODUCTORES DE CACAO DEL ECUADOR. Archives of FEDECADE, Jesus Maria, 2009.

FEDECADE. 2004. REGLAMENTO PARA LA PRODUCCIÓN DE CACAO ORGÁNICO DE LA FEDERACIÓN Nacional DE PRODUCTORES DE CACAO DE ECUADOR.. Archives of FEDECADE, Jesus Maria, 2009..

FEDECADE. 2008. Fortalecimiento del sistema de acopio y comercialización del cacao Nacional fino y de aroma, de exportación de la organización. Archives of FEDECADE, Jesus Maria, 2009.

Flores G., Marco. 2007. La proteccion juridica para el cacao fino y de aroma. Serie Magi. Quito: Universidad Andina Simon Bolivar - Ediciones Abya-Yala Corporacion Editora Nacional. 
Goodman, David, and E. Melanie DuPuis. 2002. Knowing food and growing food: Beyond the production-consumption debate in the sociology of agriculture. Sociologia Ruralis 42(1): 5-22.

Guayaquil, Redaccion. 1990. Cacaoteros rechazan proyecto. El Comercio. Guayaquil, September 91990.

Guayaquil, Redaccion. 1999. Bolsa de Productos Paralizacion Forzosa. El Expreso. Guayaquil, June 031999.

Guayaquil, Redaccion. 2004. Ventas de cacao subieron 38.7\% en el 2003 y los precios mejoran. El Universo. Guayaquil, January 042004.

Guayaquil, Redaccion. 2008. Precio del quintal de cacao favorece a las exportaciones. $E l$ Universo. Guayaquil, July 062008.

Gómez Tovar, Laura, Lauren Martin, Manuel Angel Gómez Cruz, and Tad Mutersbaugh. 2005. Certified organic agriculture in Mexico: Market connections and certification practices in large and small producers. Journal of Rural Studies 21: 461-474.

Hahn, Andrea, and Catherine Vogel. 2009. PPDC Market-oriented promotion of certified sustainable cocoa production. Eschborn. http://www.certifiedcocoa.com/download/PPDC_Flyer_Feb09_en.pdf.

ICCO. 2006. International Cocoa Organization Annual Report 2004/2005 London: International Cocoa Organization [www.icco.org].

ICCO. 2008. ASSESSMENT OF THE MOVEMENTS OF GLOBAL SUPPLY AND DEMAND EX/136/6 3 April 2008. Executive Committee 136 Meeting. Berlin: International Cocoa Organization http://www.icco.org

ICCO. 2010. ICCO Monthly and Annual Averages of Daily Prices of Cocoa Beans, 1960-2006. London: International Cocoa Organization http://www.icco.org Accesed 04/12/2010 www.icco.org/statistics/monthly.aspx?

Krenke, Melissa. 2004. On the Record: William Foote, President Ecologic Finance. Rainforest Alliance Eco-Index. Accesed online April 042010 http://www.ecoindex.org/new/record/2004/december.cfm.

Luke, TW. 2005. Neither sustainable nor development: reconsidering sustainability in development. Sustainable Development 13: 228-238. 
MAGAP, GTZ, INIAP, CONCACAO, CORPEI, Plan-Ecuador, and AMAZNOR. Organizaciones de Pequenos Productores de Cacao vinculados con Mercados Especiales. Quito: MAGAP.

McMichael, Philip. 2000. The power of food. Agriculture and Human Values 17: 21-33.

Melo, Cristian, and Steven Wolf. 2007. Ecocertification of Ecuadorian Bananas: Prospects for Progressive North-South Linkages. Studies in Comparative International Development (SCID) 42(3): 256-278.

Moberg, Mark. 2005. Fair trade and eastern Caribbean banana farmers: Rhetoric and reality in the anti-globalization movement. Human Organization 64(1): 4-15.

Norero Gonzalez, Jorge. 1988. Intereses Generales: Productores de Cacao contra el Monopolio. El Universo. Guayaquil, October 41988.

Porter, G. 1999. Trade Competition and Pollution Standards: Race to the Bottom or Stuck at the Bottom? Journal of Environment and Development 8: 133-151

Rainforest Alliance. 2009. Report on Overseas Market Opportunities for Ecuadorian Cocoa. Contract No. EPP-I-OO-O6-00013-00 TO \#377-Chemonics, Inc-USAID. Accesed August 2009 at http://www.ambiente.gob.ec/userfiles/3797/file/Report on Overseas Market Opportunities for Ecuadorian Cocoa.pdf.

Rainforest Alliance. 2009. Major European Kraft Chocolate Brands Embrace Rainforest Alliance Certification [Oct/30/2009]. Accesed August 2009 at $\mathrm{http} / / / \mathrm{www}$.rainforest-alliance.org/news.cfm?id=kraft_cocoa

Redaccion Expreso. 1991. La farsa de la bolsa de productos agropecuarios. Expreso. Quito, 20/Junio/2001.

Rios, Franz, Cristian Melo, Nestor Acosta, and Mauricio Gavilanes. 1997. Diagnostico de linea base de las especies de flora y fauna asociadas al sistema agroforestal de cacao en las cooperativas El Progreso y Nueva Union Campesina. Quito: Archives of Conservacion and Development 2009. http://www.scribd.com/doc/23761790/ESTUDIO-DE-BIODIVERSIDAD-ENEL-CACAO-CONSERVACION-DESARROLLO.

Rivera, William, and Gary Alex. 2004. Volume 2. Privatization of Extension Systems Case Studies of International Initiatives: Case Studies of International Initiatives. Initiatives. Vol. 2. Agriculture and Rural Development Discussion Paper. Washington, D.C.: The World Bank. 
Rosero, Jose Luis. 2002. Apuntes de Economia No 20: La ventaja competitiva del Cacao Ecuatoriano. Guayaquil: Direccion General de Estudios del Banco Central del Ecuador. http://www.bce.fin.ec/documentos/PublicacionesNotas/Competitividad/ Estudios/ae20.pdf.

Soria, Jorge. 1986. Informe de la mision de asesoria al Ministerio de Agricultura y Ganaderia del Ecuador sobre las actividades del Programa Nacional del Cacao (MAG). San Jose:Author. http://books.google.com/books?id=mO8qAAAAYAAJ\&dq=soria + cacao+ecuador +IICA\&source $=$ gbs_navlinks_s.

Staff. 2007. Market-oriented promotion of certified sustainable cocoa production Côte d'Ivoire: a joint project of the private and public sector to promote sustainable cocoa production. Eschborn: GTZ. Accesed online August 282010 http://www.certified-cocoa.com/download/PPDC_Project-Description_en.pdf.

Transfair. 2005. Cocoa cooperative producer profile: FEDECADE, Ecuador. Organization. Oakland: Transfair. http://www.transfairusa.org/pdfs/profiles/FEDECADE.pdf.

United Nations (UN). 1998. Strengthening of the Coordination of Humanitarian and Disaster Relief Assistance of the United Nations, Including Special Economic Assistance: Strengthening of the Coordination of Emergency Humanitarian Assistance of the UN A/53/139 - E/1998/67. United Nations, 12/Jun/1998. Accessed May 2006. http://www.un.org/documents/ecosoc/docs/1998/e199867.htm

Valdivieso S., Jose. 2008. Impactos Economicos de la Certificacion: Una presentacion en el 2do encuentro de Socios ICAA, 2008, Quito-Ecuador. Quito: Archives of Conservacion and Development, 2009.

http://amazoniandina.org/files/Presentacion_ICAA_Jose_Valdivieso_ICAA_May 08_ESP.pdf.

Vos, Rob, Margarita Velasco, and Edgar Labastida. 1999. Economic and Social Effects of El Nino in Ecuador, 1997-8. Working Paper 292. The Hague: Institute of Social Studies. http://publishing.eur.nl/ir/repub/asset/19037/wp292.pdf

Werdigier, Julia, and Julie Creswell. 2010. Trader's Cocoa Binge Wraps Up Chocolate Market. The New York Times, July 24, 2010.

Wong, Sara. 2006. Informe Preliminar No. 3: Análisis de políticas de apoyo y programas de compensacion a la agricultura familiar en Ecuador. Guayaquil: Proyecto GCP/RLA/152/IAB "Impacto de los Tratados de Libre Comercio sobre la Agricultura Familiar en América Latina e instrumentos de compensación". Guayaquil: FAO-BID. 


\section{CHAPTER IV.}

\section{COCOA FARMER'S LIVELIHOOD STRATEGIES}

\section{Introduction and Background}

Practitioners of sustainable development - in their search for a way to meet the needs of the present without compromising the ability of future generations to meet theirs-attempt to make development environmentally, socially and economically sustainable. What is not to like about finding ways to allow people to satisfy needs in ways in which benefits and tradeoffs are negotiated among equals, goes the argument. On the basis of the assumption that cooperation offers a better alternative than self-interest, sustainable development programs are conceived as alternative trade networks that offer mutual benefits to participants. Consumers get access to high-quality, traceable (safe) and ecologically/ethically superior goods; manufacturers and dealers get access to an attractive niche -market, and producers are compensated with economic premiums for the environmental and social services of their crops (McMichael 2000; Murray and Raynolds 2000; Rice 2001; Ponte 2002; Raynolds 2002). Alternative trade creates networks of virtue, which connect producers and customers in a way that transform the daily act of consumption in an exercise on ecological—and ethical—global citizenship (Seyfang 2006; Barnett et al. 2005; Clarke et al. 2007; MacMaoláin 2002). However, under the discourse of partnerships, equity and fairness - and the perception of the sustainability necessity, desirability and universality (Luke 2005) — lies a question that haunts Brundtland's (1987) definition of sustainable development: whose present, and whose future? Whose interests, and how, are represented in an alternative trade/sustainable development partnerships? (Luke, 2005). 
In this chapter, I address these questions by analyzing the role that the ideological construct of sustainability-through-trade has played in reshaping Ecuadorian cocoa production since the late 1990s. This commodity and setting present a useful lens to look at the often ignored tradeoffs of sustainability. In the simplified dialectic of current Ecuadorian production - developed and implemented by a myriad of nongovernmental, governmental and international development agencies—on one side stands the low-yield, shade-grown fine cocoa variety known as Nacional—which meets all the ecological, social, and quality requirements for alternative trade and sustainability partnerships. On the other side, stands the full-sun hybrid cocoa known as $\mathrm{CCN}-51$ - which offers high yield in exchange of the ecological services of Nacional. Thus - goes the argumentEcuador's small farmers should opt for alternative trade to protect the unique agrarian landscape of shaded cocoa farms. By joining alternative trade networks, "farmers will be able to improve their incomes, and gain further benefits from stronger social networks and changes in perception towards conservation and biodiversity" (GTZ 2007)—a rhetorical argument which carries undertones of a win-win situation that balances economic, social and ecological sustainability. However, my findings suggest that the arguments of NGOs and IGOs do not truly reflect the complex choices and options that farmers face on a day-to-day basis, nor effectively address the economic tradeoffs of these views. The emphasis on shared benefits and consensus has obscured the fact that power defines who wins and who losses out of sustainability projects.

\section{Between a rock and a hard place: Ecuador's cocoa production dilemma}

Ecuador's cocoa production is marked by Nacional, a scarce shade-grown Forastero-type fine cocoa known by unique floral or fruity "Arriba" flavor or aroma 
(Loor et al. 2009; Motamayor et al. 2008; Lerceteau et al. 1997). This kind of cocoa is mostly grown in family farms of less than seven ha. Ecuador's produces about $50 \%$ of the world harvest of fine cocoa, which in turn accounts for 3 to $7 \%$ of the world's cocoa (Jano 2007; Rosero 2002). Traditionally, Nacional cocoa is grown in a species-rich multistory cropping system in which each hectare contains a lower stratum made of 400-800 cocoa trees and 10-30 plantain plants and other fruit-bearing trees (i.e., citrus such as oranges and tangerines), and an upper stratum made of roughly 20 timber trees representing several species (Rios et al. 1997; Bentley, Boa, and Stonehouse 2004; Andersson and Gradstein 2005; Haro-Carrion et al. 2009). Shade-grown cocoa farms provide habitat for local species of amphibians, reptiles, birds and mammals, which are otherwise limited by a regional prevalence of bananas and other monoculture green deserts (Soluri 2000; Rios et al. 1997; Greenberg, Bichier, and Cruz Angón 2000; Beer et al. 1998; Bentley, Boa, and Stonehouse 2004; Faria and Baumgarten 2007; Franzen and Mulder Borgerhoff 2007; Clough, Faust, and Tscharntke 2009; Southgate and Whitaker 1992; Sierra and Stallings 1998). The mechanism that produced flavor is complex (Luna et al. 2002), but the "Arriba" aroma comes from a combination of distinctive genetics, farming practices (pre and post harvesting), and environmental factors (such as climate, soil and luminosity) that occur exclusively in Ecuador's lowlands (Motamayor et al. 2008; Deheuvels et al. 2004; Loor et al. 2009; Lerceteau et al. 1997; Cambrai et al. 2010).

However, the quality of Nacional and the richness of the agro-forestry system in which it is produced have some agricultural weaknesses, namely disease susceptibility and low yield. The Nacional genotype is highly susceptible to two fungal plant 
pathogens, Crinipellis perniciosa (known as "witch's broom," or "escoba de bruja"), and Moniliophthora roreri (known as frosty-pod disease, or "monilla") (Griffith, 2004;

Parsons, 1957). These diseases caused the collapse of the Ecuadorian cocoa production back in the early $20^{\text {th }}$ century, as $C$. perniciosa can cause yields to drop by $90 \%$ and $M$. roreri can infest and destroy up to a $100 \%$ of the pods (Henderson 1997; Pineo 1988; Griffith 2004; Parsons 1957; Hebbar 2007; Phillips-Mora and Wilkinson 2007); even today, these pathogens can cause losses of up to 50\% or more of the crop (Griffith, 2004). Second, Nacional farms — and the famed Arriba quality—are trapped in a loop in which low yields and low-intensity management go hand in hand. In 2008, Ecuador's cocoa yield of $250.3 \mathrm{~kg} /$ ha year was half the world's average $(495.5 \mathrm{~kg} / \mathrm{ha} /$ year) (FAOSTAT 2010). The country's growing exports, given cocoa groves yield remain constant overall $^{42}$ are sustained by increasing the area planted with cocoa (See Figure 1).

Although the problems of Nacional are chronic (in fact, these issues date back to the 1930's), some of them appear amenable to solutions derived from agricultural intensification methods. In fact, by 1965 an Ecuadorian agronomist by the name of Homero U. Castro-working independently in Naranjal cocoa farm aptly named "Theobroma"- developed a variety known by the abbreviation CCN-51 (which stands for Coleccion Castro Naranjal cross \# 51 $)^{43}$ as a F1 cross of IMC-67 x ICS-95 by O-1, where $\mathrm{O}-1$ is a cocoa ascension collected by Castro himself in a trip to Ecuador's Valle de

\footnotetext{
${ }^{42}$ Cocoa yield vary from year to year - because of the effects of the climatic phenomena known as El Niño Southern Oscillation (ENSO) and its La Niña counterpart, but the trend is slightly negative (decreasing yields).

${ }^{43}$ There are reports of other available CCN clones ( i.e., CCN-31 in Rohsius, Matissek, and Lieberei 2005); CCN10 and CCN16 in (Zhang et al. 2008).
} 
los Canelos (Castro 1981). The CCN-51 variety grows in full-sun, is resistant to the attack of witch's broom and frosty-pod disease, and is moderately resistant to Ceratocystis cacaofunesta (which causes the disease known as Ceratocystis Wilt of Cacao) (Engelbrecht, Harrington, and Alfenas 2007; Sanches et al. 2008). The yield of CCN-51 is high, and under "optimal circumstances" - full-sun, high density planting (2200 plants/ha), and use of inputs such as irrigation, fertilizers and other agrochemicals_-yields up to $4000 \mathrm{~kg} / \mathrm{ha}$ year, although yields of 2000-3000 kg/ha year seem to be the norm for this density and intensity of management (Espinosa et al. 2006: 36). Even at lower planting densities, $\mathrm{CCN}-51$ 's yield is 3-4 times the yield of Nacional (750-1500 kg/ha year@833 plants /ha according to Espinosa et al. 2006).

On top of superior agronomic characteristics, $\mathrm{CCN}-51$ is freely available in Ecuador, given that by the time of Castro's sudden death (late 1980's) he had not patented the variety (Victor Chacon Salinas, interview with author, Jesus Maria, December 2009). Given that CCN-51 plants were available on the haciendas where Castro conducted his trials (i.e., Hacienda Balao, Canas and Pechichal), and it is easy to graft - according to the grafting professionals I interviewed - there was a boom in the planting of this variety in large and medium cocoa farms during the 1980s and 1990s, which were looking for an alternative to the ICS-clones that had been found to be highly susceptible to Ceratocystis Wilt (Victor Chacon Salinas, interview with author, Jesus Maria, December 2009).

Information about rate of adoption of this variety is scarce, but a 1997 survey of 304 cocoa farms found that $8.8 \%$ of the total area was planted with Nacional, $85 \%$ of the area was planted with natural crosses of Nacional x Trinitario types, and just $0.3 \%$ of the 
area was planted with CCN-51 (ECU-B7 1997). By 2002, it was estimated that about 5\% of Ecuador' area dedicated to cocoa was planted with CCN-51 (9000 ha) (Quito 2001); in 2008 , it was reported that $\mathrm{CCN}-51$ accounted for $6 \%$ of the area dedicated to cocoa (27827 ha out of 463787 ha) (CORPEI 2008).

However, the rapid adoption of CCN-51 was met with resistance by high-quality chocolate manufacturers, given that it lacks the aroma of Nacional. This issue was amplified by differences between this variety and Nacional in respect to fermentation times, by the practice of mixing the production of the two varieties, and an Ecuadorian cocoa internal market failure to compensate farmers for post-harvest treatment. Cocoa beans must be fermented to develop chocolate flavors and other aromas. Nacional and related hybrids develop their particular aroma with a relatively short fermenting time of 2-4 days (Luna et al. 2002). However, CCN-51—which presents a higher amount of mucilage - requires longer fermentation time (6 days, according to Perez Piza 2006). Furthermore, the traditional fermenting methods used for Nacional did not work for CCN-51, which gained a bad reputation — although when treated well it develops a chocolate favor described as "basic-Ghana" (von Rutte 2004).

Evidently, when the two varieties were mixed the results were worse, given that neither Nacional nor CCN-51 received optimal treatment. Jürgen Rausch, of the German fine chocolate manufacturer Rausch Plantagen Schokolade, said that the effects of the practice of mixing varieties were such that some European clients have returned shipments of Ecuadorian cocoa. He said that because of the mix, fine chocolate manufacturers were sourcing fine cocoa from other countries, and that "producers and exporters that are mixing these varieties [Nacional and CCN-51] will not have the chance 
to sell cocoa as fine and aroma, and they will get paid as if they would be selling ‘consumer's cocoa' [bulk cocoa]” (Rausch in Guayaquil 2010). Finally, since the 1980’s, cocoa farmers have been receiving the same price for well fermented cocoa versus cocoa that was not fermented. The intermediaries - as was still the practice during my field work in 2009-rate cocoa beans exclusively on the basis of their humidity content. Under these conditions, farmers have incentives to dry their cocoa as soon as possible, and to avoid the labor costs and risks of fermenting the beans. The practice of fermenting was abandoned, which led to a significant loss of quality.

Consequently, in 2005, the International Cacao Organization downgraded Ecuador's cocoa rating from $100 \%$ fine flavor cocoa to $75 \%$, and informed Ecuadorian exporters that this rating could be further reduced (ICCO 2006). In this context - and under the threat of further sanctions - the problem has been framed in a way in which it appears that Ecuador's cocoa farmers must choose between two opposite paths of development. The first — the alternative trade/sustainable development model — argument is to protect and promote Nacional, and then sell the product for a higher price in specialized markets (i.e., organic, ecologic, etc). This model makes three assumptions: a) the premium of niche marketing will compensate farmers for the low productivity of Nacional farms; b) farmers will gain other benefits from investments on their social networks - thus gaining strength from collectivism; c) the economic and social benefits will provide incentives to farmers to conserve and protect their shade-grown Nacional plantations, therefore turning them into stewards of the ecological services provided by this crop. The ultimate goal of this model is to have farmer's associations that entirely bypass the conventional cocoa commercialization chain entirely, thus selling cocoa 
directly to chocolate manufacturers abroad (Radi and Ramirez 2006; Fischerworring 2007). However, proponents are willing to settle for developing "associative commercialization systems" that simply bypass the local middleman (Freire and Rios 2007). These actions will increase farmer's income by about $25 \%$, with the further benefit of producers "gaining respect" (Freire and Rios 2007).

Proponents of the alternative trade model acknowledge that there are substantial barriers to the successful implementation of even basic models of alternative trade, given that farmers' associations must make substantial improvements to meet the quality requirements of high-end chocolate manufacturers and the standards of certificationschemes - the gatekeepers of specialized market-niches. Associative commercialization depends on having the know-how to run the business and to properly manage cocoa, capital for buying cocoa stocks, communications, and infrastructure for post-harvesting (fermentation and drying) and bean storage. Thus, the successful implementation of an associative commercialization program depends on developing alliances with sources of capital to finance training and infrastructure - something that appears accessible given the number and coverage of institutions working in Ecuadorian Cocoa (see Table 1). However, producers must join in an association to access to these institutional sources of capital (Freire and Rios 2007).

Investment in Nacional is justified by the attractiveness of Nacional as highquality fine "Arriba" cocoa, with value added by certification schemes (Radi and Ramirez 2006). Fine cacao is scarce, accounting for just 5\% of the world production. Ecuador's production accounts for half of this volume. Thus, the demand for "Arriba" is 
said to be "dynamic and unsatisfied," and it is argued that this variety "will be always in demand by high quality chocolate manufacturers" (Radi and Ramirez 2006).

The second model—agricultural intensification—receives considerably less attention by NGOs and other institutions. Given that the low yield of existing Nacional plantations is caused by its susceptibility to diseases and low investment on agricultural technology, the argument is that the farmer's income will increase by changing varieties (adopting either CCN-51 or INIAP's clones of selected Nacional), and implementing better crop management practices via investments in extension services and training. Farmers also opt for replacing a fraction of their cocoa holdings for other crops (i.e., passion fruit, bananas, plantains, or papaya) which are more profitable than cocoa. The NGOs projects generally provide extension services and training, and there are projects that certainly are geared towards improving farmer's awareness about the crop (i.e., Farmer's Field Schools run by the U.S. based NGO ACDI/VOCA). Also, there are programs that deliver free or low cost improved plants—-generally CCN-51-to farmers. The technology to produce plants is simple. For example, the Puebloviejo's Technical High School — a small local institution, with contributions of Ecuador's MAGAP, INIAP and the local municipality—was able to develop and implement a program to produce and donate 50,000 CCN-51 plants (enough to plant 50 ha) to "poor farmers" of that locality in the Province of Los Ríos (Medrano 2009).

However, although producing plants is easy, there are reports that suggest that farms renovation is uncommon (ECU-B7 1997). There are two reasons that explain why farmers do not opt for farm renovation: a) renovation or replanting requires an important up-front investment (US\$ 2600/ha, according to Quiroz and Agama 2006); b) the farmer 
must be able to finance the up-keep of the renovated plantation for the 5-8 years it takes for it area to regain productivity.. All in all, this requires a period of at 8 years to break even. Renovation requires that farmers have access to medium term credit. Given the scarcity of this kind of financing, most farmers opt for renovating/replanting small extensions of their cocoa holdings on an ad-hoc basis. A similar strategy is used to deal with agricultural diversification.

Given that each model presents benefits, limitations, and liabilities, in Ecuador there is an ongoing debate about which should be planted cocoa, how and in which ways it should be produced. Supporters of Nacional put forth arguments based in this variety's status as fine cacao, market-niche potential and for the ecological services provided by shade-cocoa. On the other hand, holders of CCN-51 present arguments on the basis of its productivity, and think that this variety has been unjustly marginalized in policy circles. Fernando Crespo, President of the Association of Producers of Fine and Aroma Cacao (Asociacion de Productores de Cacao Fino y de Aroma-which despite its name agglomerates producers that have holdings of CCN-51), declared that he was concerned that "there are people that are planning to terminate CCN-51" (Fernando Crespo in Guayaquil 2010b). Crespo's fears became reality when in June of 2010 politicians and farmer's groups proposed a “Cacao Law” which aimed to finance a Nacional cocoa program with a $1.5 \%$ tax on cocoa exports - but it also made an attempt to heavily regulate plantings of other varieties (Guayaquil 2010c; Guayaquil 2010d). This proposal was rejected by other sectors. Benjamin Rosales Valenzuela—editorialist at Ecuador's most prestigious newspaper "El Comercio"-argues that the proposed ban of CCN-51 is foolish, given that this variety's yields "will allow small farmers to get out of poverty" 
(Rosales Valenzuela 2010). He also criticizes other aspects of the proposed law-which included a tax on chocolate and cocoa elaborated-product ${ }^{44}$ exports — and argues that it was designed by "retrogrades" and propelled by "neocolonialist mentalities" with the ultimate goal of keeping Ecuador' as a supplier of low cost, unprocessed beans (Rosales Valenzuela 2010). Finally, he argued against the idea of creating a Quito-based bureaucratic body to administer the tax financed "cocoa program" because the people behind this initiative are the same that are trying to stop change - thus keeping farmers poor (Rosales Valenzuela 2010).

Although individual exporters and the ANECACAO's Executive Director said that they shared the need for fomenting production, some argued that the proposed tax rate was too high (cocoa exporter Lourdes Delgado, in Guayaquil 2010c). They also expressed concerns that the law had the goal of banning further plantings of the CCN-51 variety, although the designers of the text said "that the goal [of the law] was to advance the cause of Nacional" (Vicente Urrutia in Guayaquil 2010c). Vicente Zeller, another cocoa exporter, argued that even though $\mathrm{CCN}-51$ had a bad reputation, with the development of new fermentation methods this issue has been resolved, and that there is a substantial demand for this variety (Vicente Zeller in Guayaquil 2010d). Both Zeller and Delgado expressed that instead of banning, or talking about banning a variety, there should be a survey to find "farmer's truth, given that some farmers prefer CCN-51 because it is more profitable" (Vicent Zeller in Guayaquil 2010d).

${ }^{44}$ Such as cocoa paste, cocoa licour and cocoa butter. 
In this chapter, I address this question by comparing the income that small farmers derive from Nacional and CCN-51 cocoa plots. I frame the results comparing two farmer's associations, one of which is actively selling certified organic and Rainforest Alliance cocoa, and other where farmers are selling cocoa through local markets. I also include the income of crops grown with cocoa, as well as those that are cultivated independently. I also analyze the role of farm employment in cocoa farmers' livelihood. Finally, I address the issues surrounding why a farmer selects a given variety.

\section{Methods}

The study was conducted on Ecuador's western lowlands, from May to December of 2009. Fieldwork was conducted in the provinces of Azuay, El Oro, Guayas, Los Ríos, Manabí, Santa Elena, and Santo Domingo de los Tsachilas (see Figure 2). This study gathered data from three sources: a collection of cocoa-related publications and resources collected during field-work, in-depth interviews with farmers and farmers' leaders in all the aforementioned provinces and an open-answer survey applied to farmers residing in the provinces of Azuay, Guayas and Los Ríos.

The first data source consists of approximately 100 brochures, reports and handbooks on the general topic of Ecuadorian cocoa. These documents were published by organizations involved with cocoa-development projects from 2000 to 2009. Among others, this repository contains documents published by farmer's organizations, cocoa exporters, local and international non-governmental organizations, intergovernmental organizations, government agencies and private companies. These documents range from publicity materials to documents dealing specifically with alternative trade networks. All these documents are publicly available in Ecuador, although circulation may be restricted 
because of limited number of copies. These documents are complemented with several digital repositories, among them the judicial magazine known as "Derecho Ecuador" [http://www.derechoecuador.com/] which makes copies of the Ecuadorian Official Registry freely available.

Regarding the second data source, the in-depth interviews script was designed to gather information about farmer organizations' experiences with cocoa commercialization, interactions with local and external agencies, and a general feeling about the state of the industry from farmers' perspective. The participation on the interviews was voluntary. I conducted the interviews in Spanish. I interviewed farmers and leaders from 12 cooperatives, pre-cooperatives and associations.

This study's third data source consists of an open-answer survey given to cocoa producers from Los Ríos, Guayas, and Azuay. These producers were included in the records of one of two farmers' organizations working in these provinces. The first farmer organization, the "Federacion Nacional de Productores de Cacao del Ecuador" (FEDECADE) is a federation (union of associations and cooperatives) that has about 1100 members associated with 12 farmers' groups located in the provinces of Azuay, Esmeraldas, El Oro and Guayas (see Figure 2). The FEDECADE farmers hold up to three certifications (Fair Trade, Organic and Rainforest Alliance). To achieve these certifications and develop its commercialization system, from 1997 to 2008 FEDECADE received support from several international agencies through an alliance with an Ecuadorian NGO called Conservacion y Desarrollo (CYD)(Conservation and Development). However, at the time of the study FEDECADE's commercialization 
system was not operating, and the farmers I interviewed were selling their cocoa at the local market.

The second farmer organization, the "Asociacion de Productores Organicos de Vinces" (APOV), has approximately 240 members with farms located near the town of Vinces, Province of Los Ríos (Figure 2). At the time of the study, an APOV farmer could hold two certifications (Organic and Rainforest Alliance). Contrary to FEDECADE, the APOV had not received any investment from the IGOs-NGOs conglomerate. Instead, it was created as a mutual benefit venture of cocoa farmer's, local intellectuals, Vinces' Agricultural Technology Institute of the University of Guayaquil at Vinces, an ex-NGO field agent/organic certification agent, and COFINA — a cocoa exporter that became involved in alternative trade markets via FEDECADE's experience. The APOV commercialization model does bypass local middlemen, but delivers cocoa to the exporter COFINA. COFINA then allocates APOV's Rainforest Alliance and Organic Certified cocoa to clients willing to pay for this crop. The APOV is favored by its symbiotic relationship with the Agricultural Technology Institute of the University of Guayaquil at Vinces. First, the APOV is a tenant of this institute - thus sidestepping the need for costly commercialization infrastructure. Second, the APOV farmers have access to a continuous stream of young agronomists — some of which receive cacao training from the APOV.

Both FEDECADE and APOV are established in areas that have been long dedicated to agriculture: APOV's Vinces was at the center of the late 1800's and early 1900's first Ecuadorian cocoa boom, and FEDECADE's farms are located in areas opened to the cultivation of cocoa and bananas in the early 1950's and 1960's. 
The survey was conducted at each participant's residence in the case of FEDECADE members, and at the communal point-of-sale in the case of APOV's. The interviews were conducted in Spanish by me and took about 60-90 minutes. The survey consisted of four parts (see Appendix 1). The first, personal history, is made of questions that establish age, gender and background of the farmers in the sample. The second, land management, measures the amount of land managed, and the level of fragmentation of this area. The third, cocoa and other crop production, asks questions about the crops managed by each farmer (including questions about crop variety, yield, and age of the crops); it also includes questions about farmer's perception about the benefits and liabilities of cocoa varietals. Finally, the commercialization and income section, asks questions about the income generated by cocoa under different selling modalities, and asks for other economic activities that contribute to farmer's income. In addition, APOV supplied individual farmer's cocoa sales (by variety, price and amount) data from their commercialization records. All economic and transactional data is presented in US dollars (US\$), which has been the Ecuadorian legal tender since 2000. A detailed list of the variables collected can be found in Appendix 2.

Farmer's were recruited in the sample depending on their willingness to participate in the study, and on the basis of two criteria: a) de-facto management of the land, b) being included in the rolls of associations registered with FEDECADE, or membership with the APOV. The application of these two criteria yielded a sample of 100 farmers (out of 174 possible) registered with FEDECADE's Nueva Union Campesina, 6 de Julio, Camacho and La Florida Associations, and a sample of 60 farmers (out of 223 possible) belonging to the APOV. 
In addition to the data gathered from the surveys and previously existing databases, I conducted in-depth interviews with farmers that had been or were currently involved with their community's cocoa commercialization team in the case of associations affiliated to FEDECADE. This information was complemented with interviews with FEDECADE and APOV representatives and staff, government and nonprofit organization officials, cocoa exporters, other farmer's organizations representatives and cocoa town-level middlemen. I was granted access to an anonymized version of FEDECADE and APOV commercialization databases, and other financial and economic information. A farmer's on-farm gross product is reported as the standardized Farm Gross Product in US\$ per ha year (FGP ha/year), which is the sum of income for all possible on-farm crops standardized by total farm area (see Figure 3).

None of the farmers in my sample keep detailed accounting of farm expenses, so to estimate crop expenses for cocoa Nacional and CCN-51, I rely on the Average Management Cost by Province published in the Fine Cacao Management Cost Census ${ }^{45}$ (CORPEI 2009). Data gathered with the in-depth interviews with farmers were used to estimate management cost for other crops (i.e., bananas, passion fruit or plantains). These estimates are used to calculate a farmer's Gross Agricultural Income (GAI), and the Farm Gross Income (FGI), which is a farmer's GAI divided by the area of his or her holdings (see Figure 3).

To establish the percentage of farmers whose agricultural income sets them below poverty, I compared the GAI values with the values of the Ecuadorian national extreme

\footnotetext{
${ }^{45}$ While the Census focused in Nacional, it also includes Management Costs for CCN-51 plots.
} 
poverty level and the basic income level (INEC's Canasta Familiar Vital and Canasta Familiar Basica) (INEC 2010). The INEC CFV (Canasta Familiar Vital) is set based on the survival income for a family of four; families that earn less than this amount are classified as extremely poor. The CFB, which is set at a higher level of income, sets the level below which a family of four is classified as poor. Given that GAI income data presents a yearly estimate based in the prices for October and November of 2009, I used the CFV and CFB for these months multiplied by 12 to get a comparable yearly statistic. With these caveats, the CFV level is set at a monthly income of $\$ 370.25$ for an annual value of $\$ 4443$; the CFB level is a monthly income of $\$ 522.46$ for an annual value of \$6269 (INEC 2010).

When appropriate, general statistics (i.e., mean, median, SD) were calculated using Microsoft Excel 2002 (SP3). Linear regression and other tests were conducted using Minitab 14. Survey text processing was done using QDA-Miner 3.2.3; interview data mining and sorting was done using Atlas.Ti.6.1.1.

To establish the relationship between poverty, crop diversification and area of a farmer's holding, first I classified farmers in four groups each one set by one type of crop diversification schemes I found during field work: Nacional-only, CCN-51-only, both Nacional and CCN-51, cocoa (Nacional and CCN-51) and other crops. Second, I performed linear regression analysis to establish the average gross agricultural income (GAI) as a function of the area held under a given crop diversification scheme. Then, I used the regression equations to find the area of a holding under each diversification scheme - all other things being equal — that will generate an income that sets that farmer above CFV or CFB by the type of cropping system. I follow this procedure under the 
assumption that holding the land (actively managing it) precedes receiving income from crops planted in that area.

\section{Cocoa farmer profiles}

In the survey, I found that the average FEDECADE farmer is 54 years old (with ages from 18 to 83 years) and the average APOV farmer is 55 years old (age range 24 to 83 years old), with a bias towards older farmers (see Figure 4). In both cases, the majority of respondents are male (84\% FEDECADE, 92\% APOV). ${ }^{46}$

These similarities in age and gender composition do not extend to other parameters. In a question about place of birth, slightly less than half FEDECADE farmers were born in a locality other than their current place of residence $(49 \%,<50 \mathrm{~km})$ while 9 out of 10 APOV farmers said that they were born in the town of Vinces or nearby $(90 \%$, $<50 \mathrm{~km}$ ). On average, FEDECADE farmers acquired their lands 33 years ago, with 70\% of them having done so during the 1970's land reform. The last farmer to have acquired land through land reform did so 27 years ago; after that point in time, new arrivals reportedly got their holdings by purchasing, renting, or inheritance.

About half (53\%) of FEDECADE farmers learned about cocoa from their parents. The other $47 \%$ reported that their parents had crops other than cocoa. The APOV farmers answers to the family history question indicate that $72 \%$ of their parents had or worked in cocoa; only $16 \%$ reported that their parents farmed crops other than cocoa.

\footnotetext{
${ }^{46}$ The gender proportion in the sample reflects the gender ratio of memberships in both organizations, which is skewed towards males. In fact, the gender ratio for the roster of the sampled FEDECADE associations is $83 \%$ male, $17 \%$ female; the gender ratio for the APOV roster is $87 \%$ male, $13 \%$ female (Archives of FEDECADE, 2009; Archives of APOV, 2009).
} 
Differences in regional history versus family tradition are also felt in the way that current farmers acquired their current holdings. The most common way for holding acquisition by FEDECADE farmers is through "land reform" (51\%), followed by "purchase" $(25 \%)$ and "inheritance" (19\%); APOV's most frequent holding acquisition answer is "inheritance" (45\%), followed by "purchase" (38\%) and "land reform" (11\%). A Z-test indicates that FEDECADE and APOV results are statistically different for all these parameters, with a confidence level of $95 \%$ for all other than "Purchase" (which is statistically different for a confidence level of $90 \%$ ).

The survey results show that $42 \%$ of FEDECADE farmers' depend exclusively on cocoa (both Nacional and CCN-51), 31\% raise other crops to supplement their cocoa income, and $27 \%$ rely on off-farm employment to supplement income. Only $10.1 \%$ of the APOV farmers depend exclusively on cocoa. The large majority of APOV farmers (76.3\%) supplement their income with other crops, or with off-farm income (13.6\%) (see Table 2).

Only $12 \%$ of FEDECADE's farmers and 13\% APOV's have access to loans for agriculture; survey respondents said that "there are no loans for cocoa because it yields too little," "the loans are only for short cycle," and that "the interest was too high." Interestingly, in the case of FEDECADE one middleman originated one-third of the loans; this person also bought the product of $12 \%$ of the farmers. The APOV farmers said that they did not have access to middlemen loans.

\section{Farm descriptions: holdings, varieties, and yields}

The average FEDECADE holdings are larger (7.93 ha) than the holdings of the APOV average farmer (4.58 ha). With regard to variety planted, $27 \%$ of FEDECADE 
farmers reported that they have only Nacional plants, 59\% have both Nacional and CCN51 in separated plots, and $14 \%$ have converted their holdings to exclusively $\mathrm{CCN}-51$. On the other hand, $80 \%$ of APOVs' farmers reported that their farms are planted with Nacional exclusively; $20 \%$ reported that they have land dedicated to both varieties, and none of them said that they have converted their land to the new variety. A McNemar Test for variety-planted proportions shown no statistically significant preference for any variety in the case of FEDECADE; the same test for the APOV is statistically significant showing a strong preference for Nacional. However, a farmer stated preference for one variety does not influence the amount of land dedicated to each one. The average FEDECADE Nacional planting is 5.09 ha (SD 5.75) and are 28 years old (SD 17.14); the average APOV Nacional planting is of 4.31 ha (SD 4.34) and 32 years old (SD 32.69). The average FEDECADE CCN-51 planting is smaller (2.84 ha, SD 2.74), and considerably newer than their Nacional counterparts (5 years old, SD 5.03). The average APOV CCN-51plantings are also smaller (average is 1.98 ha, SD 2.26), and newer (6.8 years old, SD 3.7). Indeed, half of the APOV farmer that got CCN-51 plants reported that these were a gift from a government program, and were less than one-year old. The average FEDECADE CCN-51-only farm is of 3.78 ha and was planted 7 years ago; as previously mentioned, no APOV farmer had a CCN-51-only farm. Finally, the mean area dedicated to Nacional by a FEDECADE farmer is statistically similar to the mean area dedicated to Nacional by an APOV farmer, the same holds for CCN-51 plantings, which indicate that farmer's in both locations strive for a balance between the yield of each variety and other factors ( i.e., lack of capital for converting plots, or strategies of crop diversification for risk reduction). 


\section{The economics of farmers' decisions: shade-grown but low yield vs. full-sun but}

\section{high yield}

FEDECADE's average farmer Nacional yield is of $379 \mathrm{~kg} / \mathrm{ha} / \mathrm{year}$ (SD 160.6) (which is higher than Ecuador's average of $250.3 \mathrm{~kg} / \mathrm{ha} /$ year); for CCN-51, the average yield is $721 \mathrm{~kg} / \mathrm{ha}$ year (SD 508.0). The APOV records show that the average organic farm yield is $295 \mathrm{~kg} / \mathrm{ha}$ year (SD 98.9), with the highest Nacional yields reached in farms using APOV's cocoa organic-farming technological package (OTP). This package, consisting of moderate shade reduction, pruning, increased cacao tree density, and use of organic approved fertilizers and disease controllers ${ }^{47}$, increases Nacional yield to an average of $587 \mathrm{~kg} / \mathrm{ha} /$ year $(\mathrm{n}=15, \mathrm{SD} 150.68)$. While these results are encouraging, the application of the OPT is limited given farmer's lack of upfront investment capital. The APOV farmers reported that CCN-51 yield is $354 \mathrm{~kg} / \mathrm{ha}$ year, with the average being weighted down by recently planted plots which make for half of the respondents ${ }^{48}$.

The FEDECADE data for Nacional shows slight negative correlations between age of plantation and yield $(-0.317, \mathrm{p}$-value $=0.001)$. A correlation age of plantings vs.

\footnotetext{
${ }^{47}$ The APOV package was developed under the leadership of the Ing. Julio Cerezo, current APOV President and former Director of the Agricultural Technology Institute of the University of Guayaquil at Vinces. It consists of replacing low-yielding cocoa trees for better plants, increasing cocoa plants density, pruning, shade reduction, fertilization and disease control (with organic products). However, the APOV handles a good part of these tasks, given that individual farmers lack the equipment and training to perform them on their own (i.e., they need an expansive gas-powered mechanical pruning saw, and sprayer pumps to apply products). For 2010, APOV is adding irrigation to this package.

${ }^{48}$ In fact, about $25 \%$ of APOV farmers that have CCN-51 received their plants during last year, as a part of a government-funded program that provided each farmer with a few (100 to 250) CCN-51 plants.
} 
yield for FEDECADE CCN-51 is positive $(0.304$, $\mathrm{p}$-value $=0.015)$. The results suggests that $\mathrm{CCN}-51$ 's peak production is reached when the crop is 10 to 15 years old, but the later behavior of the variety is unknown given that the oldest registered CCN-51 plantation in my sample was planted 20 years ago. Information gathered from two largesized local farms ( 30 ha, 25 years old; 70 ha, 5 years old) suggest that CCN-51's older plants yield remains high if adequate inputs are supplied (a farmer reported reaching $1363.63 \mathrm{~kg} / \mathrm{ha} /$ year with pruning, weeding, irrigation and fertilization). Data from APOV did not show any correlation between age of plant and yield

The FEDECADE farmers sold their cocoa in two different ways. The first modality, selling minimally processed fresh cocoa by volume (a modality know as “fresco y desvenado," fresh and depulped), had an average price of US\$117.41 per 45kg (or roughly 6 "latas" [cans]) for October and November of 2009 (n=67, SD5.87). The second was the more traditional modality of selling dried cocoa (which may have been fermented). Dried cocoa had a gate price of US\$120.66 per $45 \mathrm{~kg}(\mathrm{n}=78, \mathrm{SD} 6.28)$ for the same period.

More than a quarter of FEDECADE farmers (29\%) complain that they do not get a better price for Nacional cocoa. Indeed, I found that the difference in prices for wet Nacional and wet CCN-51 is not statistically significant: wet Nacional was sold at $\$ 117.22$ per $45 \mathrm{~kg}(\mathrm{n}=83, \mathrm{SD} 7.14)$, while wet $\mathrm{CCN}-51$ was sold at $\$ 117.66$ per $45 \mathrm{~kg}$ $(\mathrm{n}=64, \mathrm{SD}$ 6.76). The APOV farmers get a Nacional premium of $\$ 10-15$ all year round (APOV's receives CCN-51 at practically Vinces' market price).

All APOV farmers sold their cocoa under the fresh and depulped modality for an average gate price of US\$114.2 per $45 \mathrm{~kg}$ for the same period. The APOV sold this cocoa 
for an average price of US $\$ 126.90$ per $45 \mathrm{~kg}$; the difference between farmer's gate price and price of sale went to cover APOV's operational expenses (i.e., post-harvest, transportation, repayment of capital for commercialization, certifications, etc). However, the APOV gate price was US\$ 10-15 higher than Vinces' market price, thus remained attractive to the farmers. ${ }^{49}$ Indeed, APOV consistently delivered higher prices for its affiliated farmers, but geographical location certainly matters.

To visualize these prices in a larger context, when FEDECADE farmers sold wet cocoa they received $88 \%$ of ANECACAO's FOB price (ANECACAO 2010). ${ }^{50} \mathrm{~A}$ FEDECADE farmer that sold dry cocoa got $92 \%$ of the FOB. The APOV farmers only sold wet cocoa and received $87 \%$ of the FOB price. The APOV (as an institution) got paid $97 \%$ of ANECACAO FOB for dry cocoa. Overall, FEDECADE and APOV farmers received $73 \%$ of the value that their crop has in the international markets ${ }^{51}$ when selling wet cocoa.

\section{Crop diversification and on-farm income}

Crop selection and on-farm diversification influence the reported FEDECADE farm gross product (FGP) and estimated farm gross income (FGI). The FGP of FEDECADE farmers that rely on Nacional alone $(n=24)$ is $\$ 878.12$ per ha/year, while the FGP of FEDECADE farmers that rely on CCN-51 alone ( $\mathrm{n}=10)$ is $\$ 2729.65$ per ha/year

\footnotetext{
${ }^{49}$ Vinces is located at $100 \mathrm{~km}$ from Guayaquil; Naranjal is located at $45 \mathrm{~km}$ from Guayaquil, and these two points are connected by a main highway.

${ }^{50}$ ANECACAO ASE FOB averaged US\$ 130.89 per $45 \mathrm{~kg}$ for ASE quality cocoa. Cocoa ranked higher than ASE (i.e., ASS or ASSP), fetch higher prices.

${ }^{51}$ Cocoa was traded for US\$153.56 per $45 \mathrm{~kg}$ for October and November of 2009 at New York (NYSEC) and London (LIFFE).
} 
$(n=10)$. FEDECADE farmers that hold both varieties $(n=32)$ have a FGP of $\$ 1568.15$, with 33 of their gross income coming from Nacional and $66 \%$ from $\mathrm{CCN}-51$ (even though Nacional plantings are twice as large as those of CCN-51) (see Table 3). APOV figures are lower; the average FGP farmers that rely only on Nacional cocoa is of $\$ 741.63$ per ha/year $(n=10)$. The APOV sample of farmers that have CCN-51 old enough to be productive stage is too small for generalizations $(\mathrm{n}=4)$.

In the survey, $28 \%$ of FEDECADE farmers reported that they raise other crops to supplement their cocoa income. While preferences vary according to place, market, and local conditions, most farmers chose between four alternative crops: bananas, plantains, passion fruit, and citrus. Gate prices for these other crops are relatively uniform across the region. Data about average yields and gate prices can be found in table 3 (other crops). The best FGP is achieved in farms that grow $\mathrm{CCN}-51$ with another crop (plantains or citrus). These farms average FGP is $\$ 3078$ per ha/year ( $n=3)$, with $86 \%$ of the FGP coming from CCN-51 and $14 \%$ of the FGP coming from the other tree crops. The second best combination is to have Nacional, $\mathrm{CCN}-51$ and other crops (i.e., passion fruit or plantain), which yields a FGP of $\$ 2278$ per ha/year ( $\mathrm{n}=11)$, with Nacional accounting for $26 \%$ of the FGP, CCN-51 for 55\% of the FGP, and the other crops for $19 \%$ of the FGP. Following this is a combination of Nacional, $\mathrm{CCN}-51$ and Nacional-intercropped organic/Fair-Trade bananas, ${ }^{52}$ which produces a FGP ha/year of $\$ 1801(n=7)$ with $27 \%$ of the FGP coming from Nacional, $13 \%$ coming from $\mathrm{CCN}-51$ and $60 \%$ coming from

\footnotetext{
${ }^{52}$ The Fair-Trade and Organic certified bananas are sold through two channels other than FEDECADE: the El Guabo Association of Banana Producers or the Union de Campesinos del Litoral (UROCAL).
} 
bananas $^{53}$. The last alternative, planting organic/Fair Trade bananas in association with Nacional cocoa, generates a FGP of $\$ 1514$ ha/year $(n=5) .{ }^{54}$ In this case, Nacional accounts for $29 \%$ of the FGP while bananas account for $71 \%$ (see Figure 5).

Instead of fruits, 53\% of APOV's farmers plant what is colloquially known "short cycle" (ciclo corto), meaning rice or maize. ${ }^{55}$ The average FGP for farmers that raise cocoa and short cycle is $\$ 2007.3$ per ha/year $(n=32)$, with $30 \%$ of the FGP coming from the cocoa plantings and $70 \%$ of the FGP coming from the rice or maize; other alternatives (Nacional + bananas, Nacional + bananas + short cycle, Nacional + plantains $)$ average FGP is of $\$ 2651.1$ per ha/year ( $\mathrm{n}=12)$ (see Figure 5).However, I suspect that the contribution of rice or maize to the APOV farmers' income is understated for two reasons. First, "short cycle" management is input-dependent, and farmers routinely use agrochemicals (fertilizers and pesticides) on these crops, which are incompatible with APOV's organically managed cocoa. In order to maintain the all-important cocoa certification, APOV farmers have adopted the practice of physically, colloquially and mentally isolating — which fences and buffer zones, or by demurring when talking about them - these parcels from those under organic management. This "isolation-by-practice" may lead to underreporting these crops. Second, at the time of field work Ecuador's

${ }^{53}$ The farmers said that they could only cultivate and certify banana planted in association with Nacional; they did not plant banana in association with CCN-51.

${ }^{54}$ The farmers reported that the yield of 1 ha of this associated crops yielded 276 "boxes" of banana per year [6 Mt/ha/year]. At the time of the study, the gate price for a $22 \mathrm{~kg}$ "box" of organic certified banana was of $\$ 7.00$.

${ }^{55}$ In fact, by March 2010 all banana-growers were no longer members of the APOV given that they "had started using agrochemicals because their banana plants got infected with Sigatoka and the organic remedies were not enough (Ana Nivela, interview with the author, July 2010). 
government opted for establishing a 'fixed official price' for both rice and maize. This price, of $\$ 12$ per $45 \mathrm{~kg}$ of maize and $\$ 28$ per $45 \mathrm{~kg}$ of rice, made farmers reluctant to plant these crops given that "at that [official] price, one does not earn enough money to pay the production costs" (Anita Nivela, interview with the author, July 2010). This information leads me to believe that in 2009 the APOV farmers planted less of these crops than what is normal for them.

\section{On-farm production cost and farm gross agricultural income}

On farm production costs are shown in Table 5. Data for cocoa management cost (for both Nacional and CCN-51) come from the Average Management Cost by Province published in the Fine Cacao Management Cost Census (CORPEI 2009); for crops other than cocoa, management cost data were supplied by key informants (farmers or local specialists). In all cases, the yield and gate price for all crops are an average of the yields and prices reported by the farmers in my sample.

The FEDECADE's Nacional-only farms FGI average $\$ 476$ ha/year. In contrast, FEDECADE CCN-51-only farmers could earn $\$ 1380$ ha/year, even though CCN-51 production costs are higher (see Table 4). The average FEDECADE FGI of farmers that have the two cocoa varieties is $\$ 811$ ha/year. The highest FGI, of $\$ 1537$ ha/year, ${ }^{56}$ is achieved by farmers that raise plantains or oranges in association with their CCN-51 plots. The income from farmers that keep cocoa plots of Nacional and CCN-51, plus other crops (passion fruit, papaya or plantain) is $\$ 1131.03$ ha/year. Farmers with plots of Nacional cocoa, bananas associated with Nacional, and CCN-51 plots (not associated),

\footnotetext{
${ }^{56}$ Plantains or papaya are used as temporary shade for young CCN-51 plants. Citrus (normally oranges and tangerines) are used for permanent shade.
} 
generates an average FGI of $\$ 835$ ha/year. Finally, the average FGI of farmers than combine Nacional and bananas is of $\$ 696 \mathrm{ha} /$ year (see Figure 5).

The FGI of APOV farmers is lower than the FGI of FEDECADE farmers. The FGI for farmers that only grow Nacional is $\$ 352.73$ per ha/year. Farmers that have cocoa and other crops (combinations of cocoa, bananas or plantains, and short cycle) fare better, with a FGI of $\$ 1039.30$ per ha/year. Finally, the best result for an APOV farmer is to have cocoa and short cycle, an alternative that generates a FGI of $\$ 1154.80$ ha/year (see Figure 5).

\section{Agricultural income and poverty level}

As discussed in the Methods section, for the purposes of this study the Family Vital Requirements (Canasta Familiar Vital, CFV) threshold is set at an annual income level of \$4443; the Family Basic Requirements (Canasta Familiar Basica) threshold is set for an annual income of $\$ 6269$ (INEC 2010).

The comparison on farmers' Gross Agricultural Income (GAI) and Ecuador's poverty level is striking. The annual income of $47 \%$ of FEDECADE farmers is below what is needed to meet the Family Vital Requirements (CFV), the income of 19\% is above CFV but below what is needed to meet the Family Basic Requirements (CFB), and the income of 33\% is above Family Basic Requirements (CFB). The income of $71 \%$ of APOV farmers is below the CFV; the income of $11 \%$ of the farmers is above CFV but below $\mathrm{CFB}$, and the income of $18 \%$ of the farmers is above CFB.

The income of FEDECADE farmers that rely on Nacional-only cocoa farms is the lowest. The gross agricultural income of $83 \%$ of the farmers that have Nacional-only farms is below CFV, the income of $13 \%$ is above CFV but below CFB, and the income of 
$4 \%$ is above CFB. Farmers with plots of Nacional and CCN-51 fare somewhat fare better, with $60 \%$ of the farmers below CFV, $20 \%$ above CFV but below CFB, and $20 \%$ above CFB. The two best combinations found for FEDECADE farmers are Nacional, CCN-51 and Fair Trade bananas, with $29 \%$ of farmers below CFV, no farmers in the above CFVbelow $\mathrm{CFB}$ range, and $71 \%$ above $\mathrm{CFB}$, and CCN-51 with others, in which the income of $100 \%$ of the farmers is above CFB.

In the case of APOV farmers, the gross agricultural income (GAI) of $90 \%$ of the farmers that rely exclusively on cocoa is below the CFV, and the income of $10 \%$ is above CFV but below CFB. In my sample, I did not find any APOV Nacional-only farmers with income above CFB. Farmers that grow cocoa and short cycle are slightly better off, although the income of $70 \%$ of them is below CFV, the income of $3 \%$ is above CFV but below $\mathrm{CFB}$, and income of $27 \%$ is above CFB. The GAI of farmers that have cocoa and other crops (bananas or plantains and short cycle) is better, thus the income of $59 \%$ of the farmers is below $\mathrm{CFV}$, the income of $33 \%$ is under $\mathrm{CFB}$, and the incomes of $8 \%$ sets them above CFB.

The regression analysis shows a positive linear relationship between the area managed by a farmer and his income level in all cases (see Figure 6 and Figure 7). In general, farmers with smaller farms have less income. However, I found that in $24 \%$ of FEDECADE cases, and $6 \%$ of the APOV, farmers with a comparable area of holdings had different incomes (thus the income of one farmer did fall below the poverty level, while the income of other was above this level) (see Figure 8 and 9). Given that market prices and yield are relatively constant within FEDECADE's (or APOV's) area of influence, the overlap is explained by differences between cropping systems. 
Graphically, the slope of the regression trend line in plots of high yield cocoa (CCN-51) or multi-cropping systems (cocoa and other crops) is steeper: these systems generate more income per unit of area (Figure 6 and 7). For example, if a FEDECADE farmer - selling cocoa at the local market price - needs a holding of 3.43 ha of CCN-51 (or 2.89 of cocoa and other crops, i.e., passion fruit or Fair Trade bananas), for his or her income to be above CFV. However, he or she needs a holding of 12.12 ha of Nacional to reach the CFV level. The APOV farmers face a similar challenge. Thus, an APOV farmer who raises Nacional and other crops (short cycle, conventional bananas) needs a holding of 4.11 ha for his or her income to be above CFV. If an APOV farmer raises cocoa Nacional-only, this person needs holdings of 12.58 ha for his (or her) income to be above CFV. Evidently, farmer's choice matters.

\section{Risk reduction: Farmers perceptions about Nacional and CCN-51}

In the survey and interviews, I found that FEDECADE and APOV farmers view Nacional similarly. Farmers appreciate Nacional for its organoleptic characteristics of aroma, taste and flavor, which is interesting given that farmers do not asses their crop under these parameters. Of FEDECADE farmers, $90 \%$ mentioned aroma as a positive characteristic of Nacional; all APOV respondents also mentioned it. Some of FEDECADE's survey responses suggest external influence: "it is the best cocoa in the World," "[having Nacional] is our [Ecuador's] privilege;" "because even the Europeans say that it [Nacional] is the best cocoa in the world because it's great flavor and aroma" (see Figure 10). On the other hand, 70\% of FEDECADE farmers identified CCN-51's lack of aroma as this variety main weakness. 
Farmers in both locations appreciate Nacional for its final bean weight (after fermenting and drying) (49.5\% FEDECADE, 34.5\% APOV) and low-cost management (1.9\% FEDECADE, 3.1\% APOV). APOV farmers appreciate Nacional for characteristics that were not mentioned by FEDECADE farmers, such as hardiness, resilience to adverse weather (drought or flooding), "good yield" without inputs, and plant durability. The CCN-51 variety is appreciated for its yield (70\% of FEDECADE's farmers), ease of pod collection, ease of plant management (18\% FEDECADE), and resistance to disease (10\% FEDECADE's) (Figure 11). While farmers mention that this variety requires more "care" (i.e., fertilizing, irrigating, pruning) they also say that $\mathrm{CCN}-51$ 's yield makes it a worthwhile investment, and that CCN-51 "si deja platita" [CCN-51 generates profits] in the words of an anonymous survey respondent. Also, the amounts of inputs used in CCN51 must not be over emphasized — at least in the case of small farmers in Ecuador. The self-described "conventional" CCN-51 farmers I interview used herbicides (gliphosates), organic fertilizers (treated manure), urea, topical applications of copper-sulfate compounds when pruning, and insecticides to control plagues (ants), but the use of these products did not reach the amounts and prevalence of use as in other crops in the area (i.e., bananas). The FEDECADE has had Rainforest Alliance certified CCN-51 plots (although it did not find a market for these beans), and other $\mathrm{CCN}-51$ farmers reported that they managed CCN-51 the same way they managed Nacional, with water and pruning. Evidently, more research is needed on this topic: the lack of regard for CCN-51 is generating a bias against learning about the true risks and benefits of this variety.

Farmers also agree on variety's weakness. The Nacional variety susceptibility to diseases is seen as a major problem by $71 \%$ of FEDECADE farmers, and $75 \%$ of APOV 
farmers. Of diseases and pests of concern, the most frequently mentioned is frosty pod, which was identified "as the main cause of crop loss" by $29 \%$ of FEDECADE farmers and $30 \%$ of APOV farmers. An APOV farmer said that "in a bad year, losses to monilla [frosty pod] go up to $80 \%$ of the pods." The second most commonly mentioned disease is witches broom ( $27 \%$ of FEDECADE and $30 \%$ of APOV farmers), followed by parasitic plants (locally known as "hierba pajarito" (7\% FEDECADE, 2\% APOV). The least mentioned disease is cacao wilt ('mal de machete' or 'pudricion de la pata') which is a source of concern for 5\% of FEDECADE farmers with holdings of CCN-51, but it was not mentioned by FEDECADE Nacional-only holders or by any of the APOV farmers. One APOV farmer mentioned that, beyond the attack of the "witches broom", he was also concerned about Nacional losses to the disease locally known as "mancha negra" (cocoa black pod rot, Phytophthora cf. palmivora).

While susceptibility to disease (other than the cocoa wilt) is not a major concern for CCN-51 farmers, they worry about the water requirements of this variety. Additionally, CCN-51 pods' abundance and easiness of collection—cited as an advantage by most farmers - is seen as a disadvantage by others: cocoa-pods thieves strike CCN-51 plots because in a short period of time ( 1 hour or so) they can fill sacks with pods and run (even at night). Farmers argued that thieves do not hit Nacional plots, because pods are scarce, and they would need to work to make it worthwhile. ${ }^{57}$ Thus, farmers may opt for Nacional as a risk reduction strategy in areas where cocoa thievery is high.

${ }^{57}$ Altought cocoa thievery is a common event (all the farmers I interview have suffered from it), it is not reported in crime statistics. 
Finally, one survey respondent argued that his worries about CCN-51 were born out of what other people said: "son las amenazas que hay, que esta variedad no ha de valer" [there are threats [by others who say] that this variety will be worthless]. The bad reputation of CCN-51 appears to be affecting farmer's view about this variety.

On the other hand, farmers that have converted their farms to $\mathrm{CCN}-51$ are extremely critical of Nacional. For example, an unaffiliated anonymous farmer from the vicinity of El Progreso (Province of El Oro) said that he changed his farm to CCN-51 about 12 years ago because "Nacional does not give you enough money to live." He mentioned that he was continuously "working on the farm, fertilizing, irrigating, controlling diseases" but that "it [Nacional] was good for nothing, the plants did not yield." He received technical support from staff of a development project working with the nearby UNOCACE-affiliated [ex-FEDECADE] Asociation of Cacao Producers "El Progreso", but "everything was the same." He mentioned that although "El Progreso pays more for Nacional" (about \$20 over the market price per $45 \mathrm{~kg}$, similar to APOV's premium), it "is not enough." Roughly 12 years after switching to CCN-51, he says that his average yield is up to $810 \mathrm{~kg} /$ ha year, and that "he gets the same price for CCN-51 as others get for Nacional." He argues that "there is no difference; they say Nacional is better but they do not want to pay more." He finally argued that "[he] did not want anything to do with Nacional anymore: not even as a gift" (Anonymous farmer, interview with the author, La Cadena).

The closest to a defender of Nacional who I interviewed is a farmer who said he was keeping his Nacional plot because he and his son (an immigrant to the US) "loved the trees, the birds, and to have something for other animals." This farmer has plots of 
Nacional with shade of both timber and fruit-bearing trees (avocados, zapote, and others) and plots planted with a combination of CCN-51 and passion fruit. He said that Nacional was "not profitable," but argued that his other crops were. Thus, he concluded saying that he was going to keep his Nacional because the other crops gave him income to feed his family. He appreciated his Nacional forest. In his words, "it takes [shade] trees 10, 20, even 50 years to growth, and you can cut them down in minutes" (Anonymous farmer, interview with the author, Nueva Union Campesina).

\section{The Secret Economic Life of Cocoa Farmers: wearing four hats (Nacional, CCN-51, other crops and off-farm work)}

In-depth interviews with farmers reveal that they make careful analysis of the risks involved with certain agricultural choices. While this analysis is inherently done at the individual level, the overall results of the interviews suggest that farmer weighs information gathered from his/her social network, makes rough economic calculations, and makes educated guesses about the risk of a crop before launching himself/herself in a short-medium term entrepreneurial investment. For instance, I interviewed an independent, non-affiliated farmers from the town of Jesus Maria (Guayas) that decided to replace his small ( 2 ha) banana plantation "about three years ago" with cocoa because "[banana] did not really work for us [small farmers] anymore." This change from one crop to the other was not immediate; it is an ongoing process in which cacao plants' acquisition and planting have been done in steps: "[I plant cacao] when I [farmer and his family] have the means, and when the weather [rain] favors; if you get some money, you buy 600 plants, and you take care of them for a year or so with water when needed, and weed control, and one or two sacks of urea for finishing; then you wait until you get more 
money, and you plant another 900 plants. Meanwhile you have to have another job, because the plantain that you use as temporary shade does not yield enough money to survive."

This farmer planted 360 plants of Nacional "de pepa" (from seed) because "it is cheaper this way," but he sourced CCN-51 plants from a "reputable source in Naranjal, because they have one CCN-51 that is very pretty." He strongly recommended that" one has to be careful about sourcing plants," because "if you do not get good scion and stock material you get plants that are all male and later you have to replace them." This farmer planted CCN-51 because "he knew the material, he knew the genetics of the plant." About planting Nacional, he said that he thinks that "when you plant from seed you play with dice: you are not sure about anything, so although the upfront cost of CCN-51 is higher ( $\$ 0.35$ per plant of CCN-51, $\$ 0.10$ per plant of Nacional) it is cheaper at the end." This farmer accounting supports this opinion: he reported that his 360 Nacional plants yield about "one can a year [7.5 kg; $0.02 \mathrm{~kg} / \mathrm{plant}$ year];" the others $(1140 \mathrm{CCN}-51$ plants) yield 8-9 latas [68 kg; $0.06 \mathrm{~kg} / \mathrm{plant}$ year], even thought he gives both Nacional and CCN-51 plants the same treatment. Given that this farmer sold both CCN-51 and Nacional for the same gate price, this means that each one of this farmer's CCN-51 plant produces three times the income of a Nacional plant (for the same 'management' investment).

\section{Arriba: An unsustainable crop?}

The results of this study indicate that there are parts of the Ecuadorian cocoa narrative that accurately portray reality: cocoa holders and their holdings are relatively old, and poor. The agricultural income of $66 \%$ of FEDECADE and $82 \%$ of APOV 
farmers is below Ecuador's poverty line; even more, the agricultural income of $47 \%$ of FEDECADE's and $71 \%$ of APOV's members is below the extreme poverty line. There are points of commonality among these poor farmers: reduced size of holdings, and that most of them (96\% FEDECADE, 100\% APOV) have farms planted with cocoa of the Nacional variety.

The APOV case illustrates the limitations of the alternative trade model. Although APOV farmers are selling their cocoa for a price which is higher than what they can get in the local market, this premium does not allow them to rise above the poverty level. It also shows some of the limits of these trade-models: the APOV (the institution) gets $97 \%$ of the FOB value of cocoa (while farmers get $87 \%$ ) yet this difference is needed to cover the costs of meeting the quality and certification requirements of its clients. The FEDECADE farmers, with the geographical advantage of lower transportation costs, get a similar share of the FOB selling at the local market price without the premium afforded by certification.

However, there are factors that farmers control that influence their income. Of these, the results show that crop diversification strategies exert a strong influence in farmer's income. Farmers with more types of crops certainly fare better; while the crops planted vary according to region and farmer's personal assessment and preferences, I found that several combinations are possible. However, the results also indicate that Nacional lacks profitability in all planting schemes.

Thus, although most farmers still have Nacional (86\% of FEDECADE, $100 \%$ of APOV), this is changing rapidly. Thus, $59 \%$ of FEDECADE farmers and $20 \%$ of APOV farmers have plots with $\mathrm{CCN}-51$, and these plots are younger (mean $=5$ years old) and 
more productive than any Nacional plot. In the survey and interviews, I found that two factors explain this rapid change. First, simply put, $\mathrm{CCN}-51$ yield by area is up to three times the yield of Nacional, even in cases where there has been a constant, long term efforts to improve Nacional plantations. In the FEDECADE general area-whose farmers had the support of Nacional-oriented NGO projects for the last 10 years- $\mathrm{CCN}-51$ yields $721 \mathrm{~kg} / \mathrm{ha}$ year to Nacional $379 \mathrm{~kg} / \mathrm{ha}$ year. In the APOV general area CCN-51 yields are higher (354 kg/ha year) than the average Nacional' (295 kg ha/year) even thought these plots have not yet reached full production. Farmers are aware that $\mathrm{CCN}-51$ is more costly, and that it requires more 'care,' but they said that this variety's yield compensates them for the extra investment. Second, in the regional markets, a farmer gets paid the same price for both varieties; or, if the farmer is associated to a 'certified' associative commercialization organization that manages to get a differentiated price for Nacional cocoa, the amount of the premium does not compensate the farmer for the low yield of this variety.

However, farmers have found three ways around the failings of Nacional, namely Nacional-based organic agricultural intensification, multi-crop agriculture, and off-farm employment. The first strategy is shown by APOV's Organic Technology Package (OTP), which in preliminary trials delivers a yield of $587 \mathrm{~kg} / \mathrm{ha}$ year. This result also raises questions about what the OTP could do for CCN-51 trees. While the implementation of the OTP package is limited because of its costs and complexity, it shows that changes in management result in more productive cocoa farms. Unfortunately, the APOV OTP has built-in limiting factors that may prevent it from being readily transferred to other locations: it is premised on the APOV alliance with the Vinces' 
Agricultural Technology Institute of the University of Guayaquil, and leveraged on the supply of young agronomists formed at this institution. Some of the labors of the OTP, such as aggressive pruning, and shade control, require tools and training that farmers do not have. Even more, these tasks are physically demanding, risky and challenging for farmers who on average are on average 54 years old.

The second strategy is crop diversification. Either by replacing or complementing cocoa, crop diversification increases on-farm agricultural income. Evidently, farmers in different areas have developed different ways of implementing diversification: APOV farmers prefer short cycle; FEDECADE's farmers opt for bananas, plantains or passion fruit. Even the planting of plots of CCN-51 should be viewed from this perspective; it provides another source of income. The farmers face two constrains that limits the implementation of these practices: first, it is related to personal know-how, and secondly, there is a need for capital investment to plant other crops. The survey results show that the availability of agricultural loans is limited, which is a severe limitation. Furthermore, this strategy cannot be standardized: all the farmers I surveyed and interviewed have a different take on what is profitable for them, depending on their experience, labor availability, geography, and other factors. Nevertheless, crop diversification offers a further benefit: if farmers are making a decent living out of their work, some of them may opt for conserving Nacional for its aesthetic values.

The third strategy is to opt for off-farm employment. The results show that $27 \%$ of FEDECADE's and 13.6\% of APOV's survey respondents work off-farm, in occupations that go from agricultural labor for other farmers (11\% FEDECADE, $1 \%$ APOV), commerce (tending shops), trades (cleaning houses, bus and taxi drivers, 
fishermen, extracting crab meat, waiting tables), and professional services (my sample included a teacher, a doctor, an economist and a government employee). This last group, which accounts for $1 \%$ of FEDECADE and $7 \%$ of APOV farmers offers a view of a possible future for Ecuador's cocoa farming: all these people reported that the highest share of their income came from their professional occupations, and that cocoa was secondary. These professionals liked Nacional, because it was easy to keep.

In conclusion, this study shows weaknesses in the conceptualization and implementation of the alternative trade and the agricultural intensification models on the context of Ecuadorian cocoa production. Alternative trade-derived from ecological or environmental friendly certification schemes, or in varietal attributes —offers at best a limited tool to address poverty, unless accompanied by a strong agricultural intensification component. In Ecuadorian cocoa, low yield does not lead to profitability. However, agricultural intensification does not necessarily mean intensive use of agrochemicals and similar inputs. As the APOV case shows, there are other alternatives that achieve good results using organic methods. Nevertheless, an emphasis on the Nacional variety has resulted in reduced research and development for CCN-51.

Farmers have ways of increasing income that challenge the conventional view of agricultural intensification as 'one crop.' Farmers use their knowledge of local markets, their abilities, labor availability, and other agricultural, social and economic variables in ways that it maximizes their opportunities and minimizes risks: most the farmers in my survey were the survivors of three or more decades of cocoa price swings, botched government price fixing schemes, weather phenomena, and fickle markets. For some, 
their response is opting for one high yield variety (CCN-51); for others, planting crops other than cocoa. Even more opt for having Nacional, $\mathrm{CCN}-51$ and other crops.

Evidently, this suggests the need for a reevaluation of 'one-crop' development programs. While this sort of projects—on the basis of the expertise of a selected group, easily framed in terms of problems and solutions - are attractive for development agencies, they lack a farmer's nuanced understanding of the local growing conditions. This understanding — the knowledge of each farmer about himself, his land, the crops — is lost when an externally-financed solution are applied wholesale. A common complain among Ecuadorian environmentalists is that agrochemicals are used "en plancha" (in all the area of a plantation). Paradoxically, these groups apply 'sustainable development' and 'certification' projects in the same way.

The findings also point out to other failings in the contemporary discourse on Ecuadorian cocoa production. Indeed, the middlemen are part of the problem. However, instead of just ignoring them (at best) or demonizing them, there is a need to see them as part of the solutions: if an associative commercialization system is lacking, the middlemen — and their practices - remain. If the goal of a policy maker is to improve the quality of Ecuadorian cocoa, there is a need to train these agents in assessment of cocoa, following rules and procedures that are as strict as those imposed to the associative farmers.

Finally, there is a need to attack structural problems that cannot be solved by alternative trade or agricultural intensification models. There is a lack of credit for cocoa, given banker's perception of the low profitability of cocoa — and farmers cannot improve their farms because they lack credit. If some of the resources used in promoting 
alternative trade were divested for granting low-interest, 10-year term loans, more farmers could implement improvements that will allow them to increase their incomes. Also, alternative trade does reward farmers for non-transactional goods and services (i.e., ecosystem services). The premiums that the market would bear are subject to supply and demand; while a farmer's lost opportunities remain constant. Thus, farmers bear the cost of providing these services. 


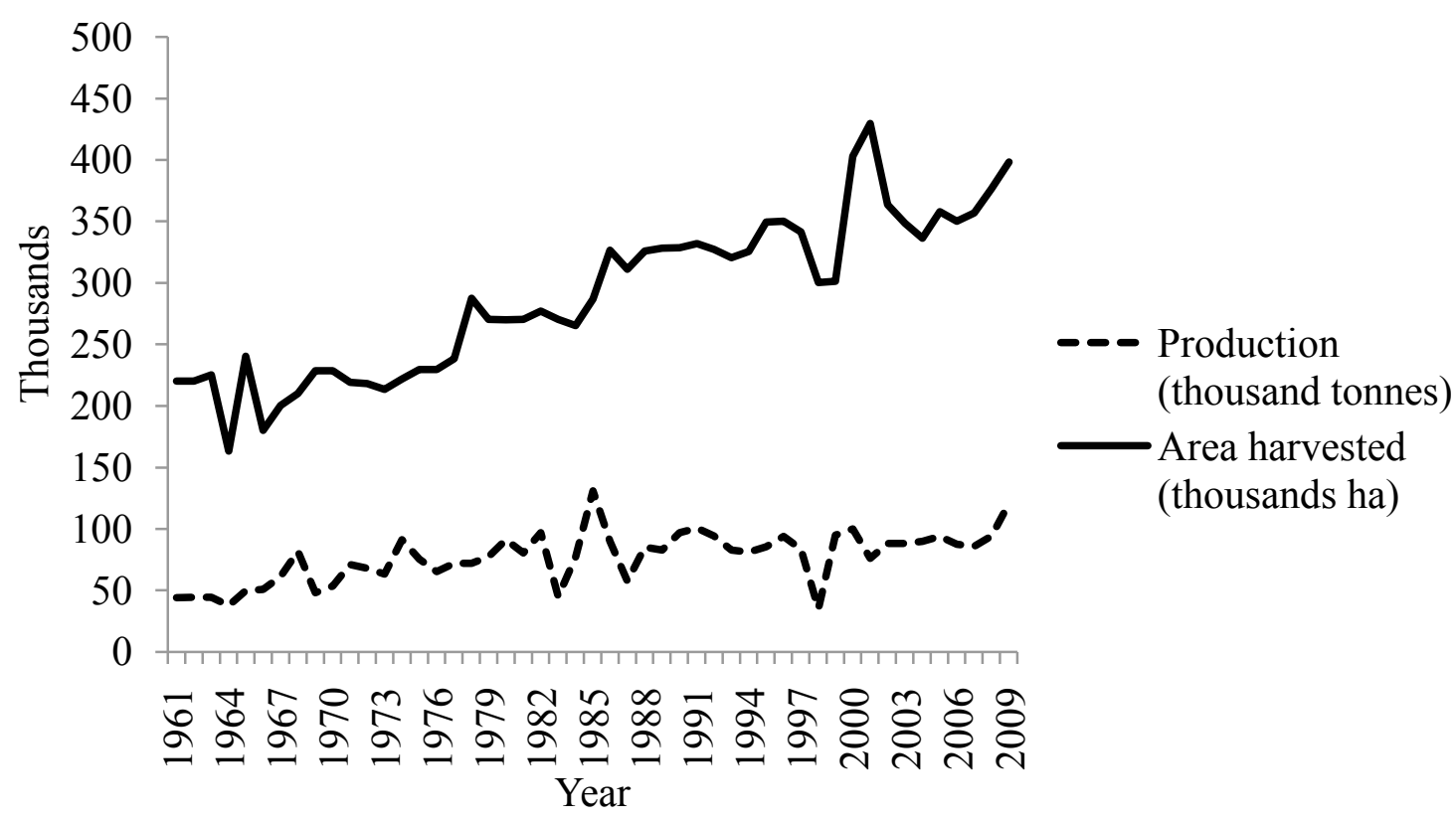

(a) Ecuadorian cocoa farms average yield by area harvested, from 1961 to 2009 (in $\mathrm{kg} / \mathrm{ha}$ year). Note: 1981-1981, 1987-1988 and 1997-1998 are years with strong influence of El Nino Southern Oscillation (ENSO). Source: FAOSTAT 2010
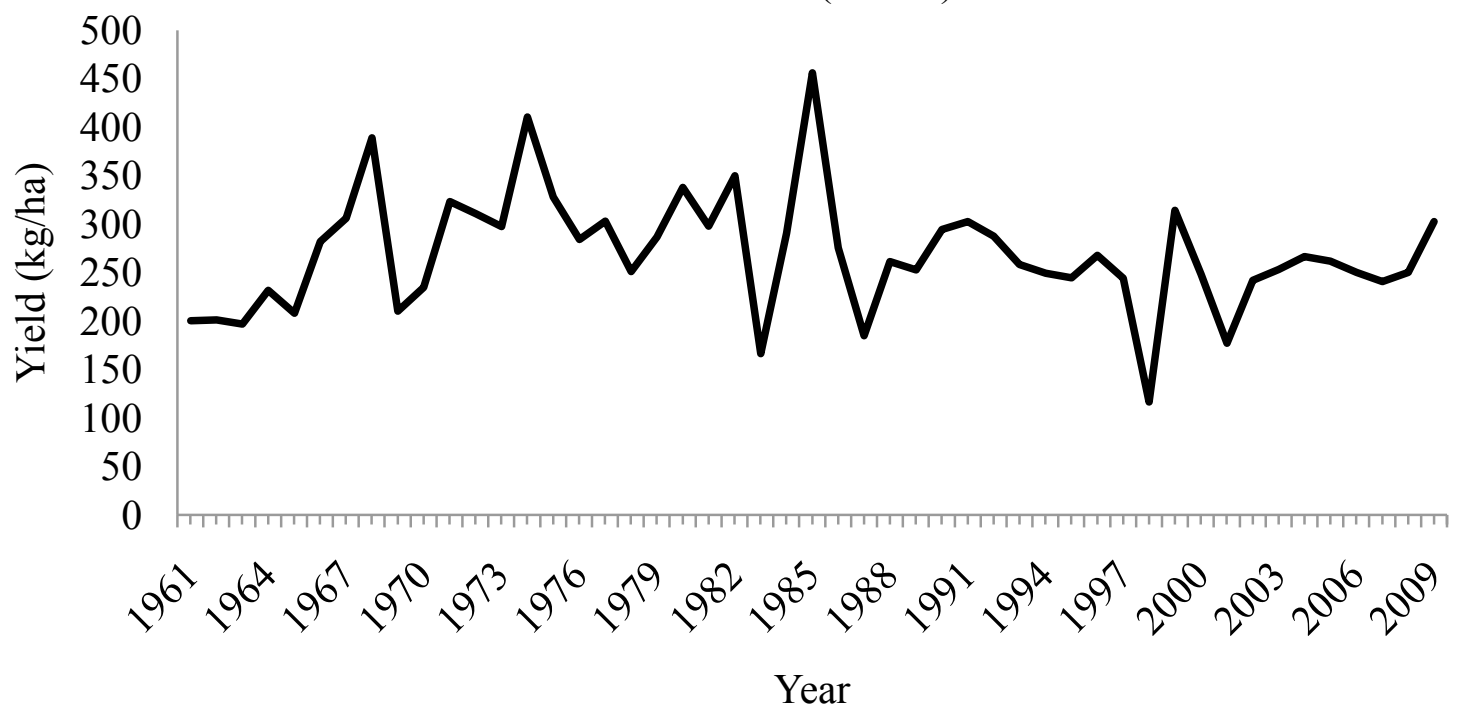

(b) Ecuadorian cocoa production (in thousand tonnes) and area harvested (in thousand ha) from 1961 to 2009. Source: FAOSTAT 2010.

Figure 1. Ecuadorian cocoa production statistics: a) production by area harvested, 19642009 ; b) production by area ( $\mathrm{kg} / \mathrm{ha}), 1964-2009$. 

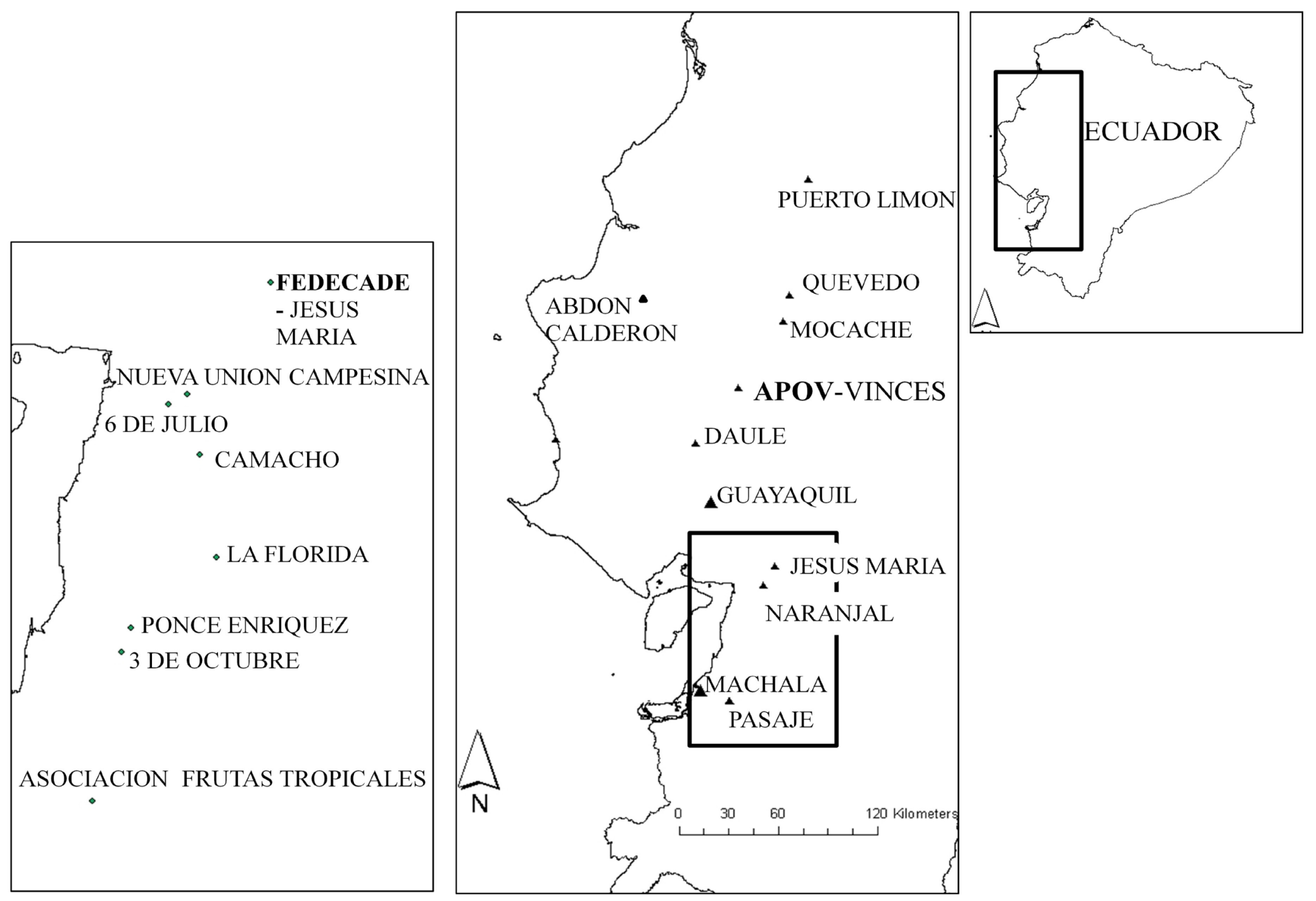

Figure 2. Area of Study. Ecuador, the Western lowlands (Costa), APOV and FEDECADE associations and cooperatives. 


$$
F G P=\frac{\sum\left[Y C_{1} \times S C_{1} \times \overline{P C_{1}}\right]+\cdots+\left[Y C_{n} \times S C_{n} \times \overline{P C_{n}}\right]}{T F S}
$$

(c) Formula to calculate standardized Farm Gross Product (FGP), where $\mathrm{YC}_{1}$ is yield for crop 1; $\mathrm{SC}_{1}$ is area for crop 1; $\mathrm{PC}_{1}$ is the reported gate price for crop 1, and TFS is the total area of the farm.

$$
F G I=\frac{\left(\sum\left[Y C_{1} \times S C_{1} \times \overline{P C_{1}}\right]+\cdots+\left[Y C_{n} \times S C_{n} \times \overline{P C_{n}}\right]\right)-\left(\sum\left[Y C_{1} \times S C_{1} \times \overline{M C_{1}}\right]+\cdots+\left[Y C_{n} \times S C_{n} \times \overline{M C_{n}}\right]\right)}{T F S}
$$

(d) Formula to calculate standardized Farm Gross Income, where $\mathrm{YC}_{1}$ is yield for crop 1; $\mathrm{SC}_{1}$ is area for crop 1; $\mathrm{PC}_{1}$ is the reported gate price for crop 1; $\mathrm{n}$ stands for crop planted (1-4), and TFS is the total area of the farm.

Figure 3. Formulas to calculate (a) standardized Farm Gross Product (FGP in US\$ ha/year) and (b) standardized Farm Gross Income (in US\$ ha year) 


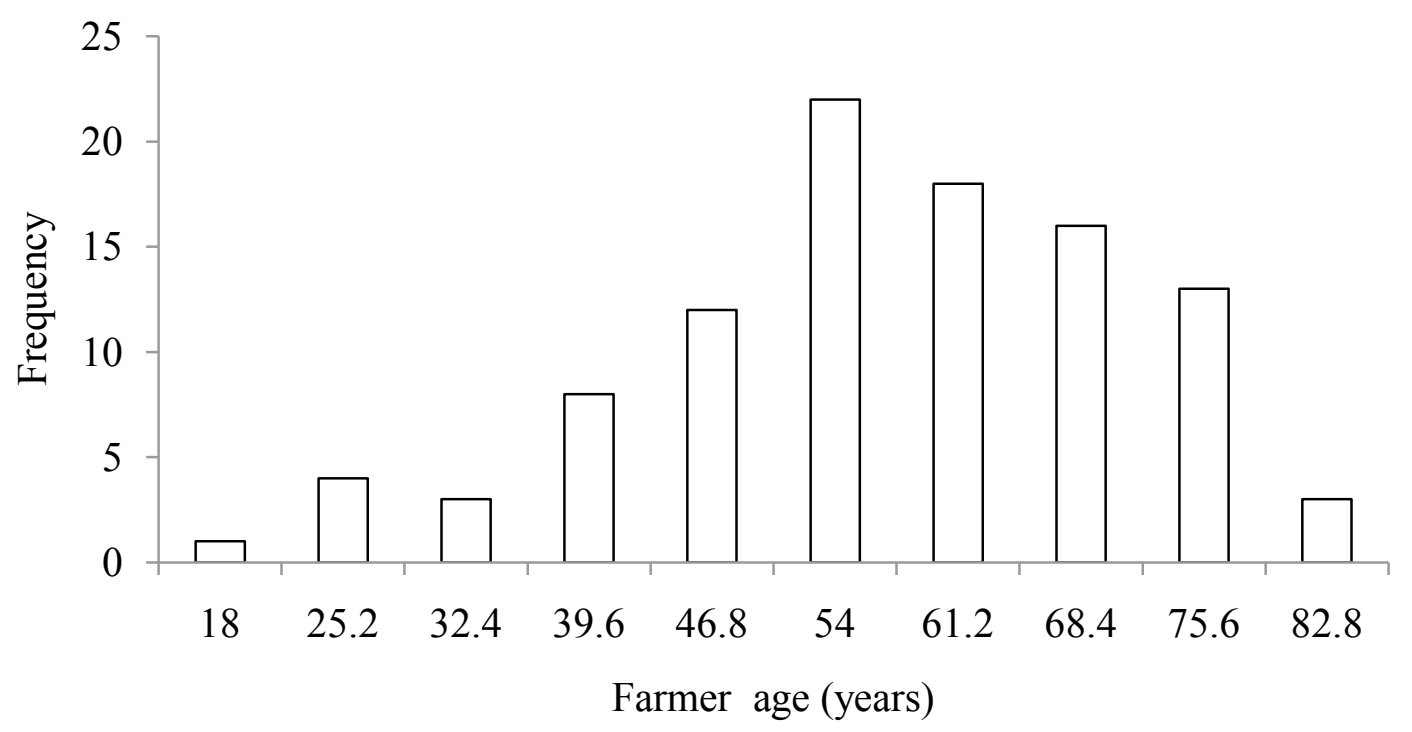

(a) FEDECADE

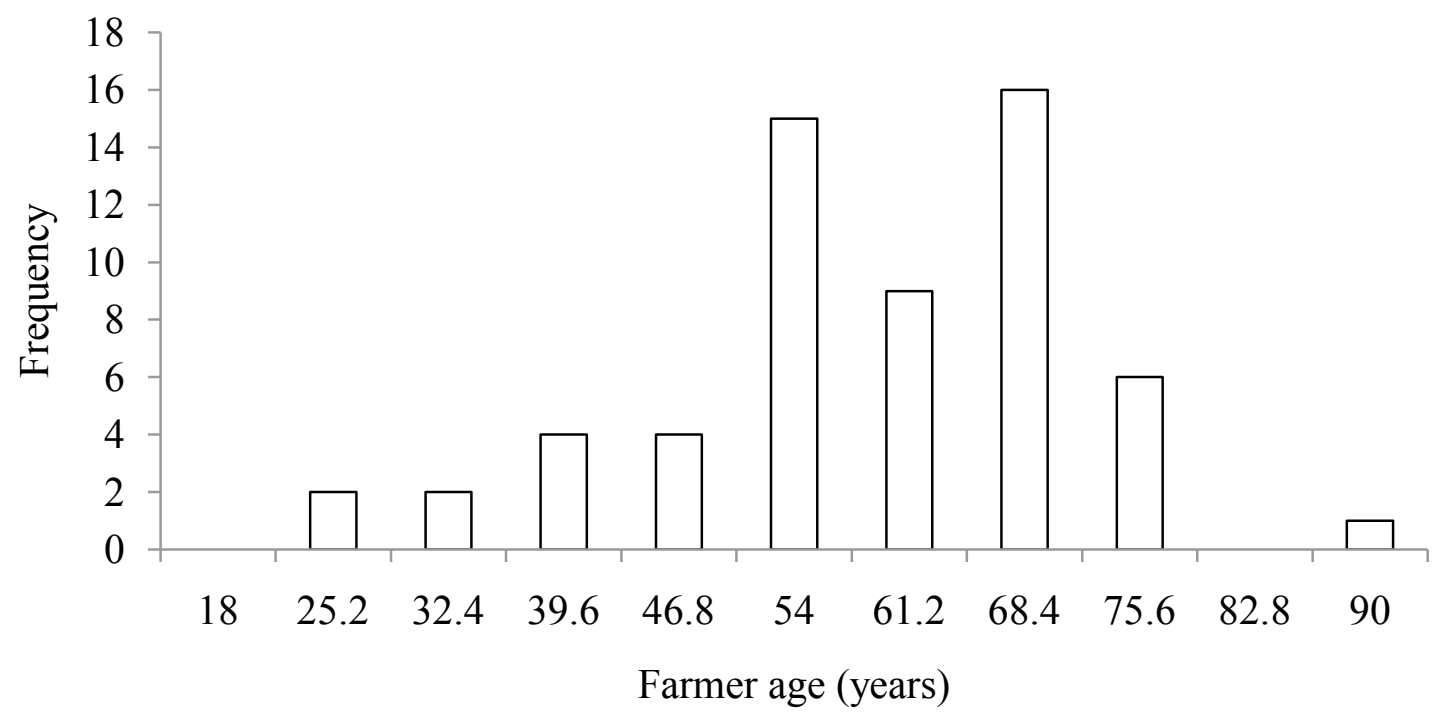

(b)APOV

Figure 4. Histogram for the frequency of farmer's age (in years) for (a) FEDECADE $(\mathrm{n}=100)$ and $(\mathrm{b})$ APOV $(\mathrm{n}=60)$. 


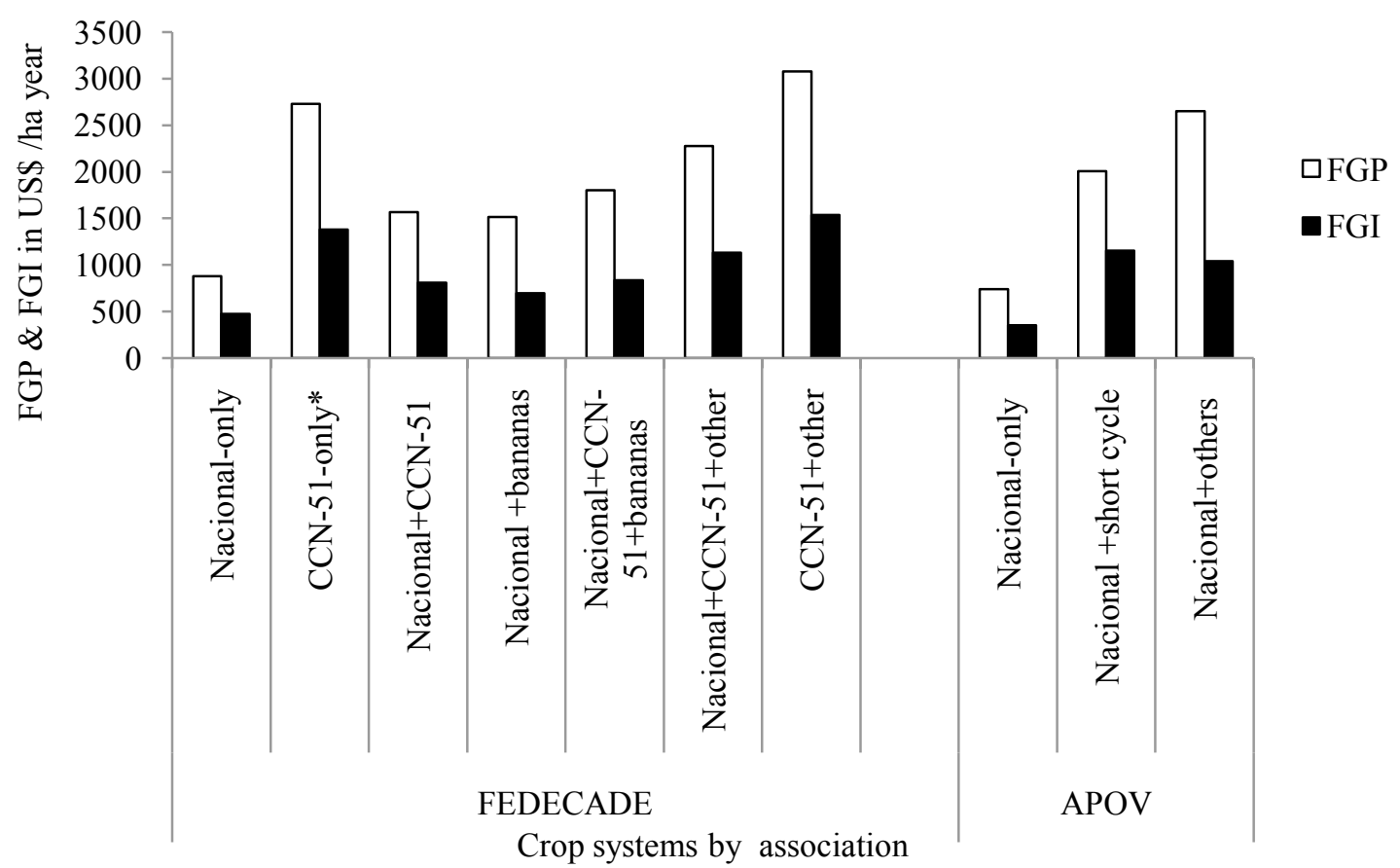

Figure 5. Standardized Farm Gross Product (FGP) and standardized Farm Gross Income (FGI) (in US\$ /ha year) by crop system by Farmer's Organization. 


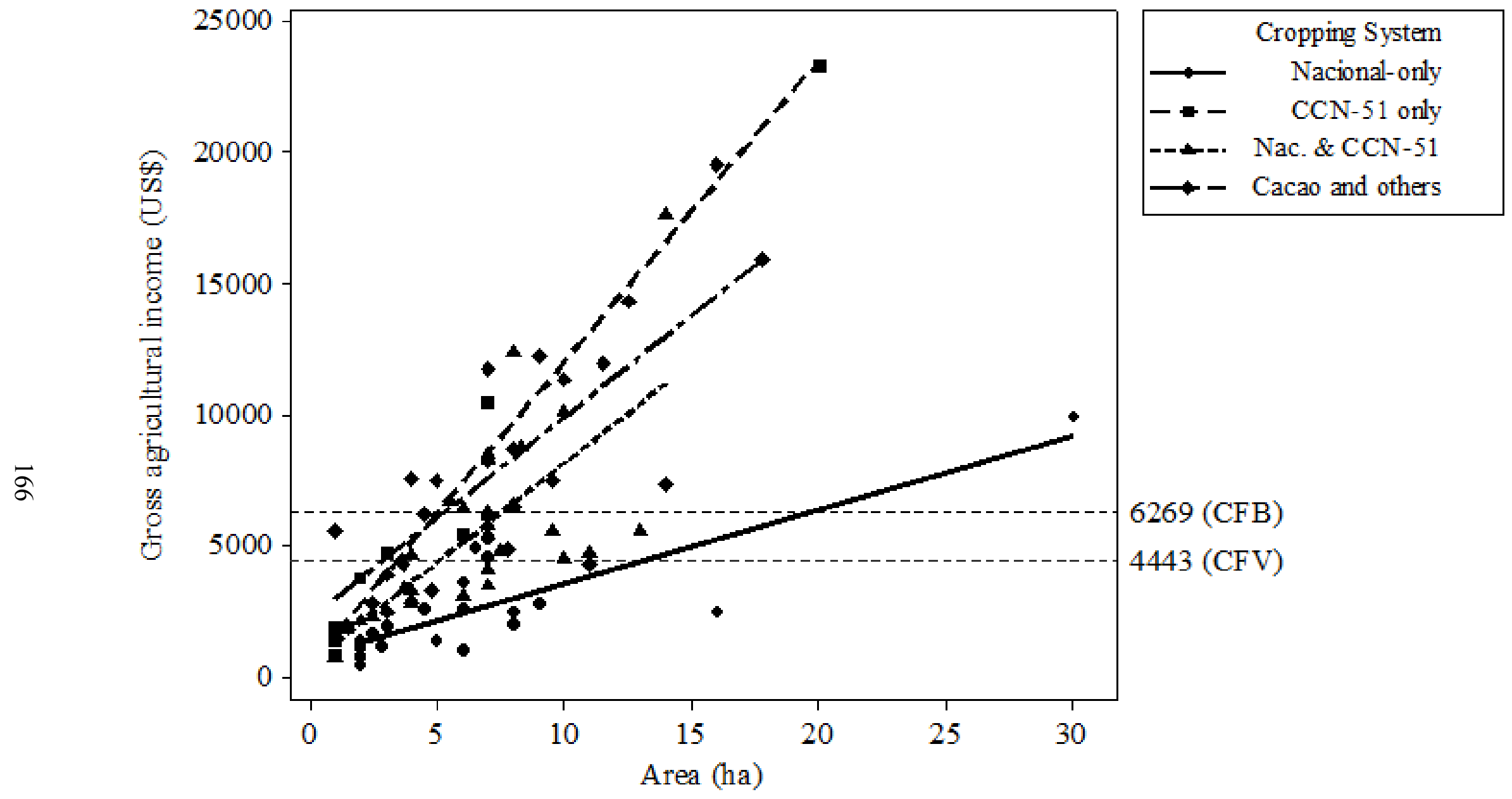

Figure 6. Regression analysis for yearly agricultural gross income (US\$) by area (ha) by cropping system for FEDECADE farmers, with guides for yearly Family Vital Income Level (CFV) and Family Basic Level (CFB). 


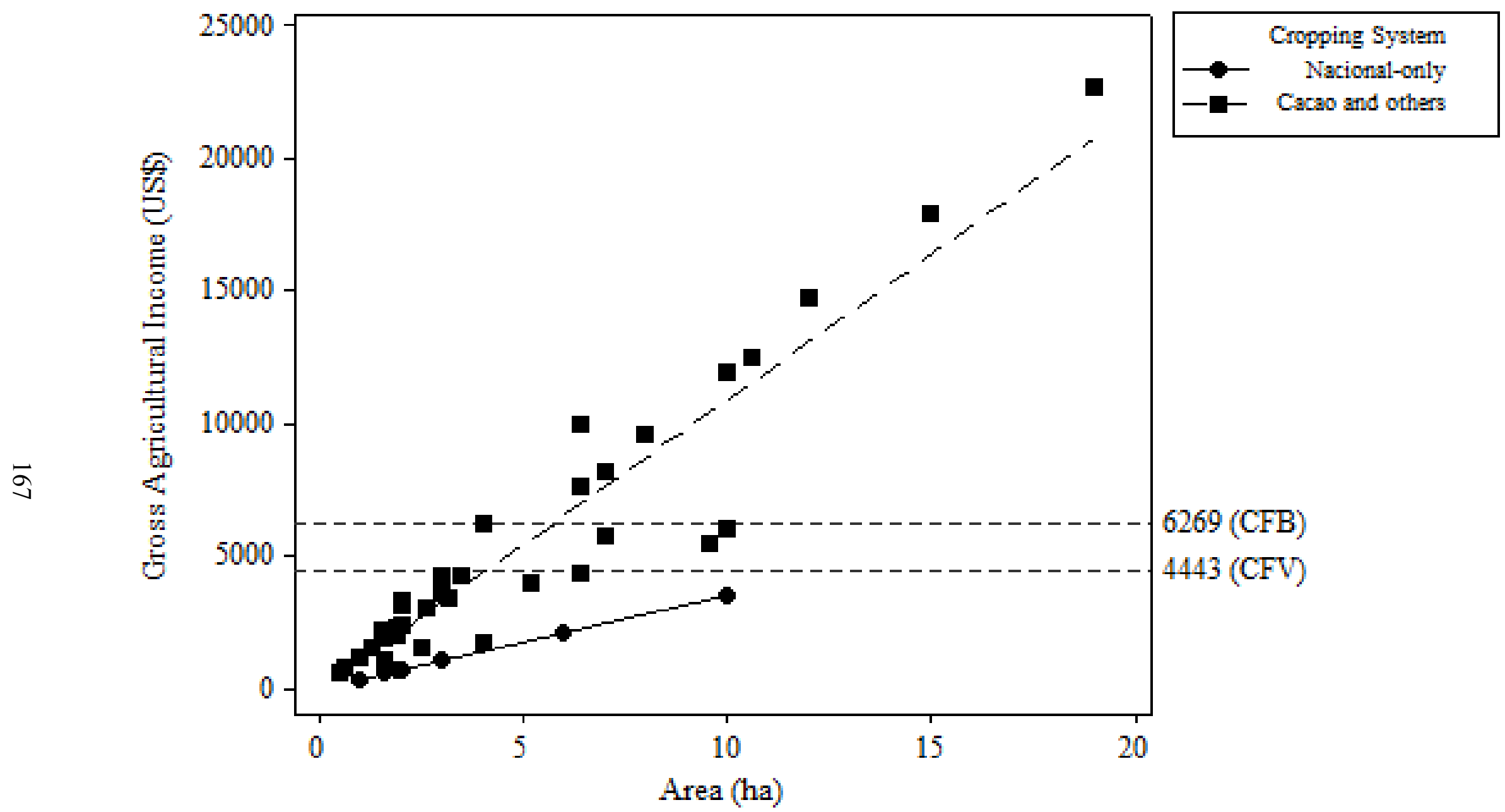

Figure 7. Regression analysis for yearly agricultural gross income (US\$) by area (ha) by cropping system for APOV farmers, with guides for yearly Family Vital Income Level (CFV) and Family Basic Level (CFB). 


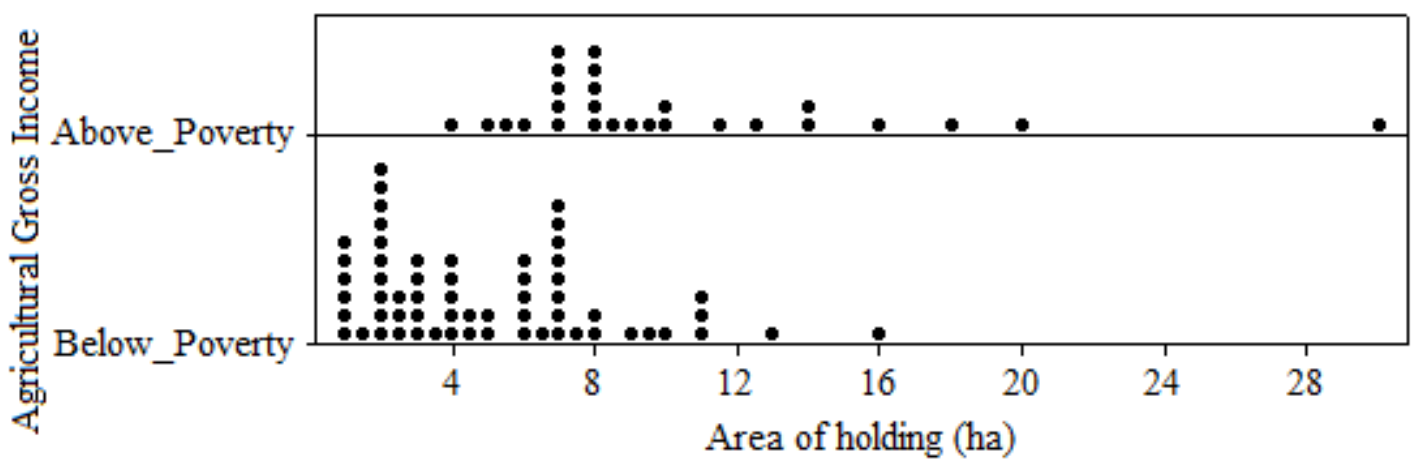

Figure 8. Dot plot for FEDECADE farmers with incomes below and above Ecuadorian poverty level (CFB) by area of holdings (ha).

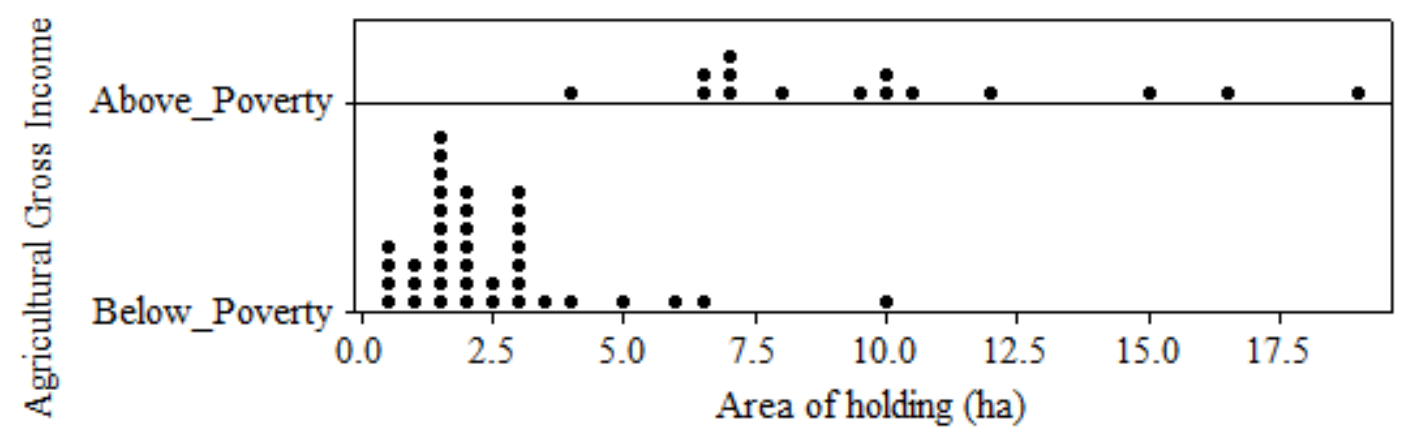

Figure 9. Dot plot for APOV farmers with incomes below and above Ecuadorian poverty level (CFV) by area of holdings (ha). 


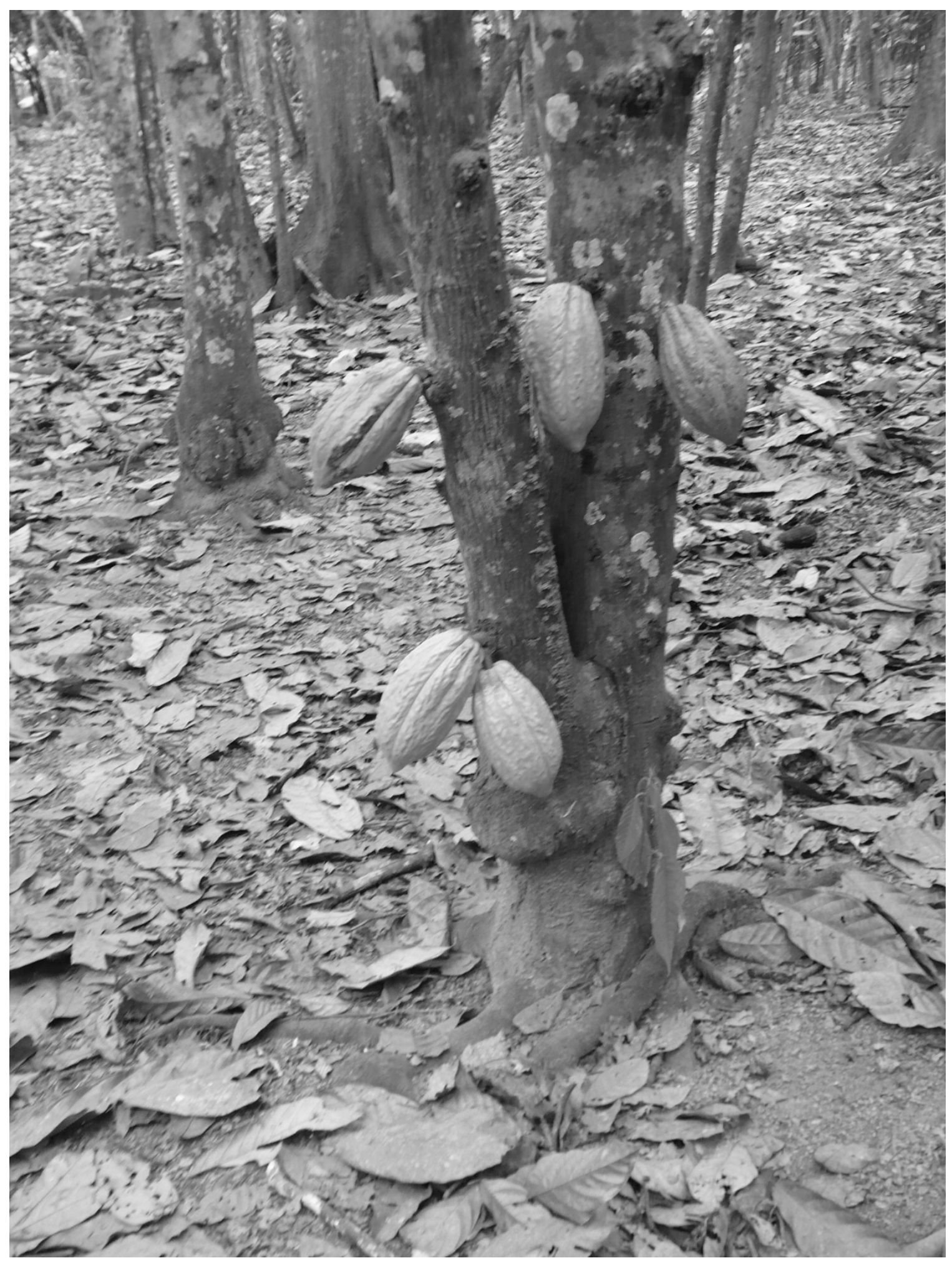

Figure 10. Tree of cacao Nacional, Nueva Union Campesina, Guayas, 2009 


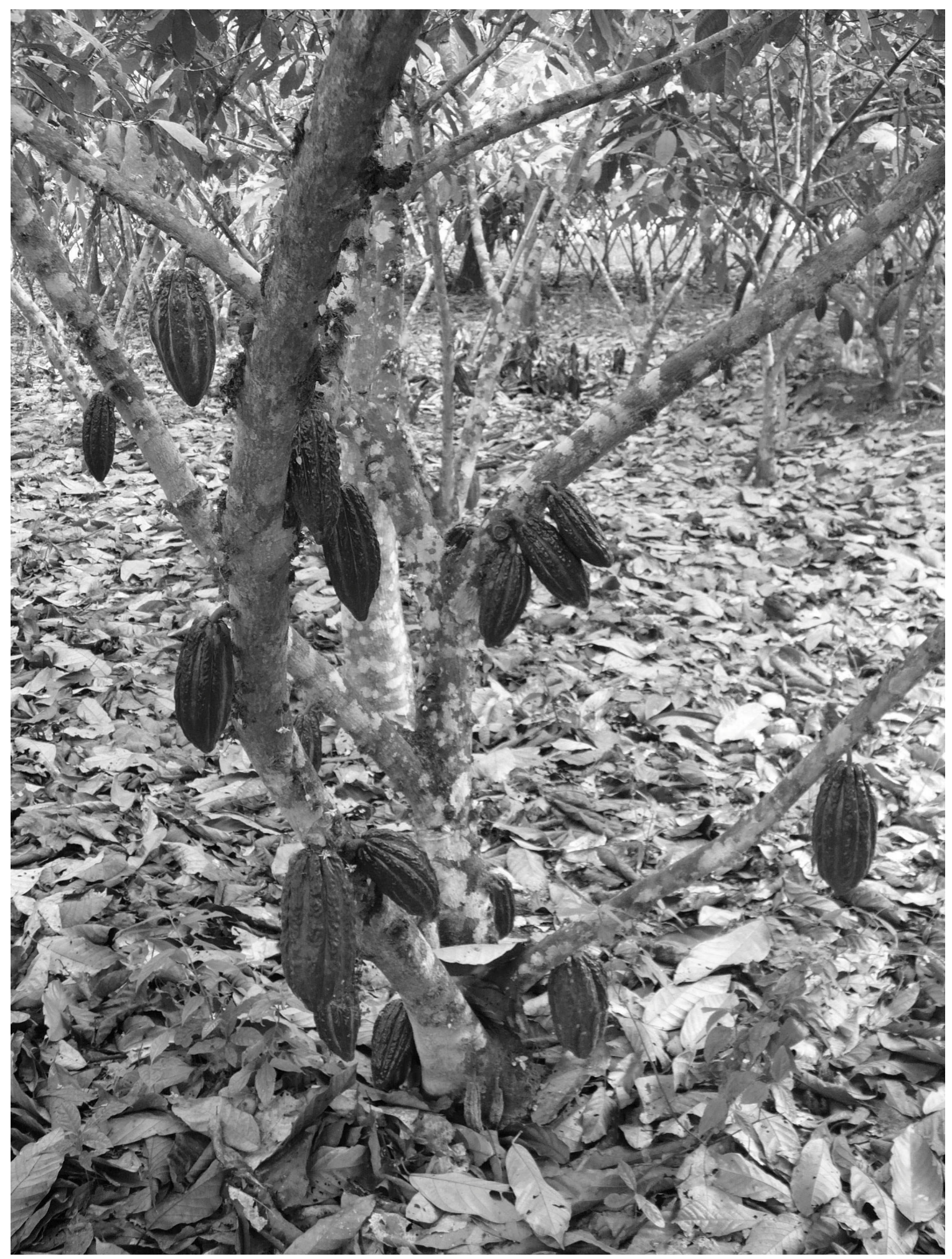

Figure 11. Tree of CCN-51 cacao, Nueva Union Campesina, Guayas, 2009 
Table 1. List of farmer's associations (FA), Ecuadorian government agencies (GA), intergovernmental organizations (IGO), projects (LFP), local government associations (LGA), non-governmental organizations (NGO), private agencies (PA), public/private sector partnerships (PPP), and University-level Educational Institutions (UEI) that have worked in Nacional related cocoa projects, 2006-2008

\begin{tabular}{|c|c|c|c|}
\hline Institution & Acronym & Country of origin & Type \\
\hline Aroma Amazonico & & Ecuador & FA \\
\hline Asociacion de Productores de Cacao de & & Ecuador & FA \\
\hline \multicolumn{4}{|l|}{ San Carlos [Association of Cocoa } \\
\hline \multicolumn{4}{|l|}{ Producers of San Carlos] } \\
\hline Corporation Fortaleza del Valle & & Ecuador & FA \\
\hline $\begin{array}{l}\text { Asociacion de Productores de Cacao de } \\
\text { Atacames [Association of Cocoa Producers } \\
\text { of Atacames] }\end{array}$ & APROCA & Ecuador & FA \\
\hline Organización de Productores de Cacao & APROCACA & Ecuador & FA \\
\hline Orgánicos Sabor Arriba & $\mathrm{O}$ & & \\
\hline Asociacion de productores de cacao del & APROCANE & Ecuador & FA \\
\hline \multicolumn{4}{|l|}{ Norte de Esmeraldas [Association of Cocoa } \\
\hline \multicolumn{4}{|l|}{ Producers of Northern Esmeraldas] } \\
\hline $\begin{array}{l}\text { Corporation Integral of Associations of } \\
\text { Camilo Ponce Enriquez }\end{array}$ & CIACPE & Ecuador & FA \\
\hline Federacion de Productores de Cacao del & FEDECADE & Ecuador & FA \\
\hline \multicolumn{4}{|l|}{ Ecuador [Ecuadorian Federation of Cocoa } \\
\hline \multicolumn{4}{|l|}{ Producers] } \\
\hline $\begin{array}{l}\text { Federación de Organizaciones Campesinas } \\
\text { del Cantón Muisne (Federation of Farmers, }\end{array}$ & FOCAME & Ecuador & FA \\
\hline Organizations of the Canton Muisne) & & & \\
\hline Federación de Organizaciones de la & FONAKIN & Ecuador & FA \\
\hline \multirow{2}{*}{\multicolumn{4}{|c|}{$\begin{array}{l}\text { Nacionalidad Kichwa de Napo [Federation } \\
\text { of Farmers' Organizations of Napo's }\end{array}$}} \\
\hline & & & \\
\hline \multicolumn{4}{|l|}{ Kichwa Nationality] } \\
\hline Association Kallari & Kallari & Ecuador & FA \\
\hline Union Cantonal de Organizaciones de & UCOCS & Ecuador & FA \\
\hline \multicolumn{4}{|l|}{ Participacion Social por la Justicia del } \\
\hline \multicolumn{4}{|l|}{ Canton Las Naves [Union of Organizations } \\
\hline of Social Participation for the Justice of the & & & \\
\hline Canton Las Naves] & & & \\
\hline
\end{tabular}

FA-Farmer's associations; GA-Ecuadorian government agencies; IGO-intergovernmental organizations; IGP-intergovernmental project; LFP-loan financed projects; LGA-local government associations; NGO-non-governmental organizations; PA-private agencies; PPP-public/private sector partnerships; UEI- University-level Educational Institutions. 
Table 1. [Continued]

\begin{tabular}{|c|c|c|c|}
\hline Institution & Acronym & Country of origin & Type \\
\hline $\begin{array}{l}\text { Union Nacional de Organizaciones } \\
\text { Campesinas Cacaoteras del Ecuador } \\
\text { [Union of Rural Cacao Organizations of } \\
\text { Ecuador] }\end{array}$ & UNOCACE & Ecuador & FA \\
\hline $\begin{array}{l}\text { Union de Organizaciones de productores } \\
\text { agropecuarios Moraspungo [Union of } \\
\text { Agriculture and Cattle Ranching Producers } \\
\text { of Moraspungo] }\end{array}$ & UOPAM & Ecuador & FA \\
\hline $\begin{array}{l}\text { Corporación de Promoción de } \\
\text { Exportaciones e Inversiones [Corporation } \\
\text { for the Promotion of Exports and } \\
\text { Investments] }\end{array}$ & CORPEI & Ecuador & GA \\
\hline $\begin{array}{l}\text { Instituto para el Ecodesarrollo Regional } \\
\text { Amazonico [Institute for the Amazon } \\
\text { Region Ecodevelopment] }\end{array}$ & ECORAE & Ecuador & GA \\
\hline $\begin{array}{l}\text { Instituto Autonomo de Investigaciones } \\
\text { Agropecuarias [Autonomous Insitute for } \\
\text { research in Agriculture and Cattle } \\
\text { Ranching ] }\end{array}$ & INIAP & Ecuador & GA \\
\hline $\begin{array}{l}\text { Ministerio de Agricultura y Ganaderia } \\
\text { [Ministery for Agriculture and Cattle } \\
\text { Ranching] }\end{array}$ & MAG & Ecuador & GA \\
\hline $\begin{array}{l}\text { Unidad de Desarollo Norte de la } \\
\text { Presidencia de la Republica del Ecuador } \\
\text { [Northern Development Unit of the } \\
\text { Ecuador's Presidency] }\end{array}$ & UDENOR & Ecuador & GA \\
\hline $\begin{array}{l}\text { Deutsche Entwicklungsdienst [German } \\
\text { Development Service] }\end{array}$ & DED & Germany & IGO \\
\hline $\begin{array}{l}\text { Deutsche Gesellschaft für Technische } \\
\text { Zusammenarbeit [German Agency for } \\
\text { Technical Cooperation] }\end{array}$ & GTZ & Germany & IGO \\
\hline $\begin{array}{l}\text { Swiss Agency for Cooperation and } \\
\text { Development }\end{array}$ & $\mathrm{SDC}$ & Switzerland & IGO \\
\hline $\begin{array}{l}\text { Agency for International Development of } \\
\text { United States of America }\end{array}$ & US AID & US & IGO \\
\hline
\end{tabular}

FA-Farmer's associations; GA-Ecuadorian government agencies; IGO-intergovernmental organizations; IGP-intergovernmental project; LFP-loan financed projects; LGA-local government associations; NGO-non-governmental organizations; PA- private agencies; PPP-public/private sector partnerships; UEI- University-level Educational Institutions. 
Table 1. [Continued]

\begin{tabular}{|c|c|c|c|}
\hline Institution & Acronym & Country of origin & Type \\
\hline $\begin{array}{l}\text { Proyecto de generacion de ingresos y } \\
\text { empleo para la frontera norte del Ecuador } \\
\text { [US AID] [Project for the generation of } \\
\text { income and employment for Ecuador's } \\
\text { northern border] }\end{array}$ & PRONORTE & Ecuador-US & IGP \\
\hline $\begin{array}{l}\text { Programa de desarrollo sostenible de la } \\
\text { frontera Amazonica Norte(Loan BID } \\
1420 / \text { OC EC) } \\
\text { [Program for the Sustainable Development } \\
\text { of the Northern Amazonic Frontier] }\end{array}$ & AMAZNOR & Ecuador & LFP \\
\hline $\begin{array}{l}\text { Consorcio de Municipios Amazonicos } \\
\text { [Amazonic Municipalities Consortium] }\end{array}$ & COMAGA & Ecuador & LGA \\
\hline Fundacion Altropico & & Ecuador & $\mathrm{NGO}$ \\
\hline Fundacion Equinoccio & & Ecuador & NGO \\
\hline Fundacion Jatun Sacha & & Ecuador & NGO \\
\hline Fundacion Same & & Ecuador & $\mathrm{NGO}$ \\
\hline $\begin{array}{l}\text { Agricultural Cooperative Development } \\
\text { International and Volunteers in Overseas } \\
\text { Cooperative Assistance }\end{array}$ & $\mathrm{ACDI} / \mathrm{VOCA}$ & US & $\mathrm{NGO}$ \\
\hline $\begin{array}{l}\text { Corporación Esmeraldeña para la } \\
\text { Formación y Desarrollo Integral } \\
\text { [Esmeraldas' Corporation for Integral } \\
\text { Education and Development] }\end{array}$ & CEFODI & Ecuador & NGO \\
\hline $\begin{array}{l}\text { Conservacion y Desarrollo } \\
\text { [Conservation and Development] }\end{array}$ & CYD & Ecuador & $\mathrm{NGO}$ \\
\hline $\begin{array}{l}\text { Fondo Ecuatoriano de Cooperacion para el } \\
\text { Desarrollo [Ecuadorian Fund of } \\
\text { Cooperation for Development] }\end{array}$ & FECD & Ecuador & $\mathrm{NGO}$ \\
\hline $\begin{array}{l}\text { Fundacion Ecuatoriana de Tecnologia } \\
\text { Apropiada [Ecuadorian Foundation for } \\
\text { Appropiate Technology] }\end{array}$ & FEDETA & Ecuador & NGO \\
\hline Fondo Ecuatoriano Populorum Progressio & FEPP & Ecuador & $\mathrm{NGO}$ \\
\hline $\begin{array}{l}\text { Fundación para el Desarrollo y la } \\
\text { Creatividad Productiva } \\
\text { [Foundation for the Development and the } \\
\text { Creative Productivity] }\end{array}$ & FUNDES & Ecuador & $\mathrm{NGO}$ \\
\hline Yachana Foundation & FUNEDESIN & Ecuador/US & $\mathrm{NGO}$ \\
\hline
\end{tabular}

FA-Farmer's associations; GA-Ecuadorian government agencies; IGO-intergovernmental organizations; IGP-intergovernmental project; LFP-loan financed projects; LGA-local government associations; NGO-non-governmental organizations; PA- private agencies; PPP-public/private sector partnerships; UEI- University-level Educational Institutions. 
Table 1. [Continued]

\begin{tabular}{|c|c|c|c|}
\hline Institution & Acronym & Country of origin & Type \\
\hline $\begin{array}{l}\text { Fundacion de promocion y accion para el } \\
\text { Desarrollo } \\
\text { (Foundation for the Promotion and Action } \\
\text { for Development] }\end{array}$ & FUNPAD & Ecuador & NGO \\
\hline Fundaccion Maquita Cusunchik & $\mathrm{MCCH}$ & Ecuador & NGO \\
\hline $\begin{array}{l}\text { Asociacion Nacional de Exportadores de } \\
\text { Cacao } \\
\text { [Nacional Association of Cocoa Exporters] }\end{array}$ & ANECACAO & Ecuador & PA \\
\hline $\begin{array}{l}\text { Bundesverband Großhandel, Außenhandel, } \\
\text { Dienstleistungen e.V. [Federation of } \\
\text { German Wholesale and Foreign Trade] }\end{array}$ & BGA & Germany & PA \\
\hline $\begin{array}{l}\text { Corporacion Ecuatoriana de Cafetaleros } \\
\text { [Coffee-growers Ecuadorian Corporation] }\end{array}$ & CORECAF & Ecuador & PA \\
\hline $\begin{array}{l}\text { Biocomercio Sostenible [Sustainable } \\
\text { Biotrade] }\end{array}$ & Biocomercio & Ecuador & PPP \\
\hline $\begin{array}{l}\text { Sistema de Capacitación en el Manejo de } \\
\text { los Recursos Naturales Renovables-System } \\
\text { for training in Natural Resources } \\
\text { Management }\end{array}$ & $\begin{array}{l}\text { Consorcio } \\
\text { CAMAREN }\end{array}$ & Ecuador & PPP \\
\hline $\begin{array}{l}\text { Escuela Politecnica del Ejercito } \\
\text { [Army Polytecnic School] }\end{array}$ & ESPE & Ecuador & UEI \\
\hline Universidad Luis Vargas Torres & ULVT & Ecuador & UEI \\
\hline
\end{tabular}

FA-Farmer's associations; GA-Ecuadorian government agencies; IGO-intergovernmental organizations; IGP-intergovernmental project; LFP-loan financed projects; LGA-local government associations; NGO-non-governmental organizations; PA-private agencies; PPP-public/private sector partnerships; UEI- University-level Educational Institutions. 
Table 2. On-farm and off-farm sources of income FEDECADE and APOV farmers.

\begin{tabular}{|c|c|c|c|c|c|}
\hline \multirow{2}{*}{\multicolumn{2}{|c|}{ Source of income }} & \multicolumn{2}{|c|}{ FEDECADE } & \multicolumn{2}{|c|}{ APOV } \\
\hline & & $\mathrm{n}$ & $\%$ & $\mathrm{~N}$ & $\%$ \\
\hline \multicolumn{6}{|c|}{ On-farm } \\
\hline & Cacao only & 42 & 42.0 & 6 & 10.1 \\
\hline & Other crops & 31 & 31.0 & 45 & 76.3 \\
\hline & & & 73.0 & & 86.4 \\
\hline \multicolumn{6}{|l|}{ Off-farm } \\
\hline & Agricultural & 11 & 11.0 & 1 & 1.7 \\
\hline & Commerce & 3 & 3.0 & 1 & 1.7 \\
\hline & Professional & 1 & 1.0 & 4 & 7.7 \\
\hline & Services & 3 & 3.0 & 1 & 1.7 \\
\hline & Trade & 8 & 8.0 & --- & --- \\
\hline & Multiple & 1 & 1.0 & --- & --- \\
\hline & Pension & --- & --- & 1 & 1.7 \\
\hline & & & 27.0 & & 13.6 \\
\hline
\end{tabular}

Table 3. Crops systems, number of farmers, standardized farm gross product (FGP) (in US\$/ha year), proportion of FGP from each crop, standardized farm gross income (FGI) in (US\$/ha year) and rank of that cropping systems for FEDECADE and APOV.

\begin{tabular}{llllll} 
Crops by farm & N & $\begin{array}{l}\text { FGP ha/year } \\
\text { (US \$) }\end{array}$ & $\begin{array}{l}\text { Share FGP } \\
\text { ha/year by } \\
\text { crop by farm }\end{array}$ & $\begin{array}{l}\text { FGI } \\
\text { ha/year } \\
\text { (US\$) }\end{array}$ & $\begin{array}{l}\text { Rank } \\
(1-7)\end{array}$ \\
\hline $\begin{array}{l}\text { FEDECADE } \\
\text { Nacional-only }\end{array}$ & 24 & 878.12 & 100 & 476.17 & 7 \\
CCN-51-only* & 10 & 2729.65 & 100 & 1380.27 & 2 \\
Nacional+CCN-51 & 32 & 1568.15 & $33: 67$ & 811.65 & 5 \\
Nacional+bananas & 5 & 1514.61 & $29: 71$ & 696.47 & 6 \\
Nacional+CCN-51+bananas & 7 & 1801.60 & $27: 13: 60$ & 835.59 & 4 \\
Nacional+CCN-51+other & 11 & 2278.09 & $26: 55: 19$ & 1131.03 & 3 \\
CCN-51+other & 3 & 3078.52 & $86: 14$ & 1537.93 & 1 \\
APOV & 10 & 741.63 & 100 & 352.73 & 3 \\
Nacional-only & 32 & 2007.30 & $30: 70$ & 1154.80 & 1 \\
Nacional+short cycle & 12 & 2651.1 & $30: 70$ & 1039.30 & 2 \\
Nacional+others & 12 & & & & \\
\hline
\end{tabular}

*Only CCN-51 plantations older than 5 years were counted. 
Table 4. Crop (by farmer's organization), yield (as reported and in standard units) gate price (as reported and in standard units), production cost (as reported and in standard units)

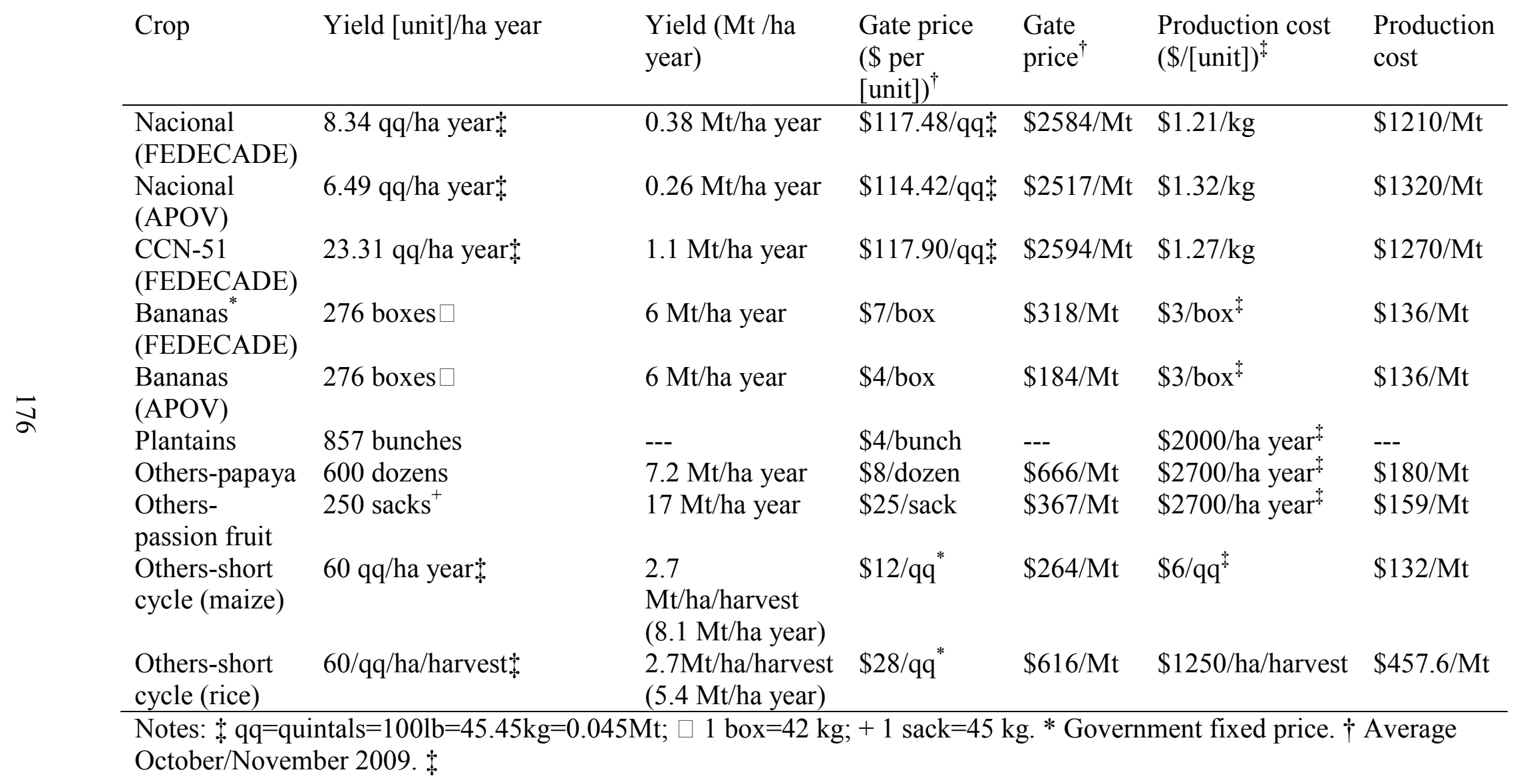


Table 5. Area (ha) by cropping system and farmer's association needed for farmer's agricultural gross income to be above Ecuador's extreme poverty level (CFV) and poverty level (CFB)

\begin{tabular}{llrr} 
& & \multicolumn{2}{c}{ Area (ha) } \\
\cline { 3 - 4 } Farmer's & Cropping System & CFV & \multicolumn{2}{c}{ income $>$} \\
CFB & & \\
\hline FEDECADE & Nacional & 13.12 & 19.65 \\
& CCN-51 & 3.43 & 5.01 \\
Nacional and & & \\
CCN-51 & 5.12 & 7.52 \\
& Cocoa and others & 2.89 & 5.26 \\
\hline APOV & & & \\
\hline & Nacional & 12.58 & 17.75 \\
& Cocoa and others & 4.11 & 5.78 \\
\hline
\end{tabular}


Table 6. Regression analysis equations for agricultural gross income (US\$) by area (ha) by cropping system and farmer's association.

\begin{tabular}{|c|c|c|c|c|c|c|}
\hline \multirow{2}{*}{$\begin{array}{l}\text { Association } \\
\text { FEDECADE }\end{array}$} & \multirow{2}{*}{$\begin{array}{l}\text { Cropping System } \\
\text { Nacional Only }\end{array}$} & \multicolumn{5}{|c|}{ Regression Analysis: GAI versus Area } \\
\hline & & Regression Equation & \multicolumn{4}{|c|}{$\mathrm{GAI}=495+1153$ Area } \\
\hline & \multirow[b]{5}{*}{ CCN-51 Only } & Predictor & Coef SE & Coef & $\mathrm{T}$ & $\mathrm{P}$ \\
\hline & & Constant & 767.0 & 343.0 & 2.24 & 0.036 \\
\hline & & Area & 280.16 & 40.60 & 6.90 & 0.000 \\
\hline & & $\mathrm{S}=1189.09$ & $\mathrm{R}-\mathrm{Sq}=68.4 \%$ & $\mathrm{R}-\mathrm{Sq}(\operatorname{adj})=67.0 \%$ & & \\
\hline & & Regression Equation & \multicolumn{4}{|c|}{$\mathrm{GAI}=767+280$ Area } \\
\hline & \multirow[b]{5}{*}{$\begin{array}{l}\text { Nacional+CCN- } \\
51\end{array}$} & Predictor & Coef SE & Coef & $\mathrm{T}$ & $\mathrm{P}$ \\
\hline & & Constant & 495.4 & 447.3 & 1.11 & 0.300 \\
\hline & & Area & 1152.79 & 62.99 & 18.30 & 0.000 \\
\hline & & $\mathrm{S}=1118.02$ & $\mathrm{R}-\mathrm{Sq}=97.7 \%$ & $\mathrm{R}-\mathrm{Sq}(\operatorname{adj})=97.4 \%$ & & \\
\hline & & Regression Equation & \multicolumn{2}{|c|}{$\mathrm{GAI}=551+760$ Area } & & \\
\hline & \multirow{9}{*}{ Cocoa + Others } & Predictor & Coef SE & Coef & $\mathrm{T}$ & $\mathrm{P}$ \\
\hline & & Constant & 551 & 1164 & 0.47 & 0.639 \\
\hline & & Area & 760.2 & 155.7 & 4.88 & 0.000 \\
\hline & & $\mathrm{S}=2518.42$ & $\mathrm{R}-\mathrm{Sq}=46 \%$ & $\mathrm{R}-\mathrm{Sq}(\operatorname{adj})=44.1 \%$ & & \\
\hline & & Regression Equation & \multicolumn{2}{|c|}{$\mathrm{GAI}=2282+723$ Area } & & \\
\hline & & Predictor & Coef SE & Coef & $\mathrm{T}$ & $\mathrm{P}$ \\
\hline & & Constant & 2282 & 1404 & 1.62 & 0.119 \\
\hline & & Area & 723.5 & 153.9 & 4.70 & 0.000 \\
\hline & & $\mathrm{S}=3271.59$ & $\mathrm{R}-\mathrm{Sq}=51.3 \%$ & $\mathrm{R}-\mathrm{Sq}(\mathrm{adj})=48.9 \%$ & & \\
\hline
\end{tabular}


Table 6. Continued.

\begin{tabular}{|c|c|c|c|c|c|c|}
\hline \multirow{2}{*}{$\begin{array}{l}\text { Association } \\
\text { APOV }\end{array}$} & \multirow{2}{*}{$\begin{array}{l}\text { Cropping System } \\
\text { Nacional Only }\end{array}$} & \multicolumn{5}{|c|}{ Regression Analysis: GAI versus Area } \\
\hline & & Regression Equation & \multicolumn{4}{|c|}{$\mathrm{GAI}=0.0153+353$ Area } \\
\hline & \multirow{9}{*}{ Cocoa+others } & Predictor & Coef SE & Coef & $\mathrm{T}$ & $\mathrm{P}$ \\
\hline & & Constant & 0.01527 & 0.01355 & 1.13 & 0.292 \\
\hline & & Area & 353.186 & 0.002 & 173428 & 0.000 \\
\hline & & $\mathrm{S}=0.0306912$ & $\mathrm{R}-\mathrm{Sq}=100 \%$ & $\mathrm{R}-\mathrm{Sq}(\operatorname{adj})=100.0 \%$ & & \\
\hline & & Regression Equation & \multicolumn{4}{|c|}{$\mathrm{GAI}=-66+1096$ Area } \\
\hline & & Predictor & Coef SE & Coef & $\mathrm{T}$ & $\mathrm{P}$ \\
\hline & & Constant & -66.3 & 348.6 & -0.19 & 0.850 \\
\hline & & Area & 1096.25 & 57.10 & 19.20 & 0.000 \\
\hline & & $\mathrm{S}=1570.49$ & $\mathrm{R}-\mathrm{Sq}=89.8 \%$ & $\mathrm{R}-\mathrm{Sq}(\mathrm{adj})=89.5 \%$ & & \\
\hline
\end{tabular}




\section{REFERENCES}

Andersson, Meike S, and S Robbert Gradstein. 2005. Impact of management intensity on non-vascular epiphyte diversity in cacao plantations in western Ecuador. Biodiversity \& Conservation 14: 1101-1120.

ANECACAO. 2010. Estadisticas de Exportacion de cacao por calidades. Guayaquil: Asociacion Nacional de Exportadores de Cacao. http://www.anecacao.com Accessed online 02/02/2010

Barnett, Clive, Paul Cloke, Nick Clarke, and Alice Malpass. 2005. Consuming Ethics: Articulating the Subjects and Spaces of Ethical Consumption. Antipode 37(1):2345.

Beer, J, R Muschler, D Kass, and E Somarriba. 1998. Shade management in coffee and cacao plantations. Agroforestry Systems 38: 139-164.

Bentley, Jeffery W, Eric Boa, and John Stonehouse. 2004. Neighbor Trees Shade, Intercropping, and Cacao in Ecuador. Human Ecology 32(2): 241-270.

Brundtland, G.H. 1987. Our common future [The Brundtland report]. World Commission on Environment and Development. Oxford; New York: Oxford University Press, 1987.

CORPEI. 2008. Cacao Ecuador Calidad de Origen. Quito: CORPEI- Corporacion de Promoción de Exportaciones e Inversiones.

CORPEI. 2009. Costos de Mantenimiento de Cacao de Fino de Aroma. S. Pino and L. Vera. Guayaquil: CORPEI- Corporacion de Promoción de Exportaciones e Inversiones-Dupre Artes Graficas.

Cambrai, Amandine, Christophe Marcic, Stéphane Morville, Pierre Sae Houer, Françoise Bindler, and Eric Marchioni. 2010. Differentiation of chocolates according to the cocoa's geographical origin using chemometrics. Journal of agricultural and food chemistry 58(3): 1478-83.

Castro, Homero U. 1981. Posibilidad de creacion de una nueva variedad de cacao de fruto hexalocular por cruzamiento entre flores mutantes hexameras.

Naranjal:Author. Archives of Victor Chacon Salinas, Jesus Maria, 2010.

Clarke, Nick, Clive Barnett, Paul Cloke, and Alice Malpass. 2007. Globalising the consumer Doing politics in an ethical register. Political Geography 26: 231-249. 
Clough, Yann, Heiko Faust, and Teja Tscharntke. 2009. Cacao boom and bust: sustainability of agroforests and opportunities for biodiversity conservation. Conservation Letters 2(5): 197-205.

Deheuvels, O, B Decazy, R Perez, G Roche, and F Amores. 2004. The first Ecuadorean 'Nacional' cocoa collection based on organoleptic characteristics. Trop. Sci. 44: 23-27.

ECU-B7, Proyecto. 1997. Documento del Proyecto No.22: Principales Caracteristicas de la Produccion y Mejora de la Calidad del Cacao en el Ecuador. Guayaquil.

Engelbrecht, CJ, TC Harrington, and Acelino Alfenas. 2007. Ceratocystis Wilt of CacaoA Disease of Increasing Importance. Phytopathology 97(12): 1648-1649.

Espinosa, José, Francisco Mite, Sergio Cedeño, Sandra Barriga, and Javier Andino. 2006. GIS-Based Site-Specific Management of Cocoa. Better Crops 90(1): 36-39.

FAOSTAT. 2010. Production and Trade statistics. Food and Agriculture Organization. http://faostat.fao.org/. Accessed online 01/01/2010-09/20/2010

Faria, Deborah, and Julio Baumgarten. 2007. Shade cacao plantations (Theobroma cacao) and bat conservation in southern Bahia, Brazil. Biodiversity \& Conservation 16: 291-312.

Fischerworring, Beatriz. 2007. Mercados y productos con valor diferenciadors. In Programa de Capacitacion en la Cadena del Cacao, Dennis Garcia, Soledad Duenas, and Pedro Ramirez, 12. 2007 ed. Quito: Consorcio Camaren.

Franzen, Margaret, and Monique Mulder Borgerhoff. 2007. Ecological, economic and social perspectives on cocoa production worldwide. Biodiversity \& Conservation 16: 3835-3849.

Freire, Jaime, and Franz Rios. 2007. Comercializacion asociativa y gestion comercial. In Programa de Capacitacion en la Cadena del Cacao, Dennis Garcia, Soledad Duenas, and Pedro Ramirez. 2007 ed. Quito: Consorcio Camaren.

GTZ. 2007. Organizaciones de pequenos productores de cacao vinculados con mercados especiales. Quito: GTZ-GESOREN.

Greenberg, Russell, Peter Bichier, and Andrea Cruz Angón. 2000. The conservation value for birds of cacao plantations with diverse planted shade in Tabasco, Mexico. Animal Conservation 3: 105-112.

Griffith, Gareth W. 2004. Witches brooms and frosty pods threats to world cacao production. Biologist 51(2): 71-75. 
Guayaquil, Redaccion. 2010. Un Aleman quiere evitar la mezcla del cacao fina. El Universo. Guayaquil, March 222010.

Guayaquil, Redaccion. 2010. Cacaoteros solicitan participar en la ley. El Universo. Guayaquil, January 092010.

Guayaquil, Redaccion. 2010. El impuesto al cacao genera rechazo. El Comercio. Guayaquil, August 022008.

Guayaquil, Redaccion. 2010. El sector cacaotero genera su debate ante propuesta de ley. El Universo. Guayaquil, August 172010.

Haro-Carrion, Xavier, Tannya Lozada, Hugo Navarrete, and G H J de Koning. 2009. Conservation of Vascular Epiphyte Diversity in Shade Cacao Plantations in the Choco Region of Ecuador. Biotropica 41(4): 520-529.

Hebbar, Prakash K. 2007. Cacao Diseases Important Threats to Chocolate Production Worldwide Cacao Diseases A Global Perspective from an Industry Point of View. Phytopathology 97(12): 1658-1663.

Henderson, Paul. 1997. Cocoa, Finance and the State in Ecuador, 1895-1925. Bulletin of Latin American Research 16(2): 169-186.

ICCO. 2006. International Cocoa Organization Annual Report 2004/2005 London: International Cocoa Organization. http://www.icco.org Accesed online Jan 01 2010 .

INEC. 2010. Estadisticas Economicas-Estadisticas de Precios-IPC-Series Historicas: Canasta Familiar Vital y Canasta Familiar Basica. Quito: Instituto Nacional de Estadistica y Censos. Accesed online 09/04/2010 http://www.inec.gov.ec/web/guest/ecu_est/est_eco/ind_eco/ipc/inf_act_ind/ser_hi S

Jano, Pilar A. 2007. Quality Incentives and the Development of High-value Agrifood Markets: Ecuador's Cacao Marketing Chain. M.Sc. Thesis. Virginia Technological University. http://scholar.lib.vt.edu/theses/available/etd06082007-131653/.

Lerceteau, Estelle, James Quiroz, Jorge Soria, Sophie Flipo, Vincent Petiard, and Dominique Crouzilat. 1997. Genetic differentiation among Ecuadorian Theobroma cacao L. accessions using DNA and morphological analyses. Euphytica 95: 77-87. 
Loor, R. G., A. M. Risterucci, B. Courtois, O. Fouet, M. Jeanneau, E. Rosenquist, F. Amores, A. Vasco, M. Medina, and C. Lanaud. 2009. Tracing the native ancestors of the modern Theobroma cacao L. population in Ecuador. Tree Genetics \& Genomes 5(3): 421-433.

Luke, TW. 2005. Neither sustainable nor development: reconsidering sustainability in development. Sustainable Development 13: 228-238.

Luna, Fabienne, Dominique Crouzillat, Loic Cirou, and Peter Bucheli. 2002. Chemical composition and flavor of Ecuadorian cocoa liquor. J. Agric. Food Chem. 50(12): 3527-3532.

MacMaoláin, C. 2002. Ethical Food Labelling: The Role of European Union Freetrade in Facilitating International Fairtrade. Common market law review 39: 295-314.

McMichael, Philip. 2000. The power of food. Agriculture and Human Values 17: 21-33.

Medrano, Antonio. 2009. Estudiantes regalarán plantas para impulsar cultivo de cacao. El Universo. Guayaquil, August 312009.

Motamayor, Juan C, Philippe Lachenaud, Jay Wallace Da Silva E Mota, Rey Loor, David N Kuhn, J. Steven Brown, and Raymond J. Schnell. 2008. Geographic and Genetic Population Differentiation of the Amazonian Chocolate Tree (Theobroma cacao L). PLoS One 3(10): 1-8

Murray, D L, and L T Raynolds. 2000. Alternative trade in bananas: obstacles and opportunities for progressive social change in the global economy. Agriculture and Human Values 17(1): 65-74.

Parsons, James J. 1957. Bananas in Ecuador A New Chapter in the History of Tropical Agriculture. Economic Geography 33(3): 201-216.

Perez Piza, Rosa. 2006. Infraestrutura de Postcosecha. In Programa de Capacitacion en la Cadena de Cacao, Denis Garcia, Susana Ruggiero, and Pedro Ramirez, 14. 1st, 2006. Quito: Consorcio CAMAREN.

Phillips-Mora, W., and M J Wilkinson. 2007. Frosty Pod of Cacao A Disease with a Limited Geographic Range but Unlimited Potential for Damage. Phytopathology 97(12): 1644-1647.

Pineo, Ronn F. 1988. Reinterpreting labor militancy: the collapse of the cacao economy and the general strike of 1922 in Guayaquil, Ecuador. Hispanic American Historical Review 68(4): 707-736 
Ponte, Stefano. 2002. The 'Latte Revolution '? Regulation, Markets and Consumption in the Global Coffee Chain. World Development 30(7): 1099-1122.

Quiroz, James, and Juan Agama. 2006. Establecimiento de Plantaciones. In Programa de Capacitacion en la Cadena Cacao, Dennis Garcia and Maria Belen Cevallos, 34. 1st editio. Quito: Consorcio Camaren.

Quito, Redaccion. 2001. Ecuador reduce su produccion de cacao y queda rezagado en la region. Diario Hoy. Quito.

Radi, Claudia, and Pedro Ramirez. 2006. El abc para la comercializacion directa de cacao especial y con certificacion. 1st editio. Quito: GTZ-GESOREN Componente Calidad y Acceso a los Mercados.

Raynolds, LT. 2002. Consumer/producer links in fair trade coffee networks. Sociologia Ruralis 42(2): 404-424.

Rice, Robert A. 2001. Noble goals and challenging terrain: organic and fair trade coffee movements in the global marketplace. Journal of Agricultural and Environmental Ethics: 39-66.

Rios, Franz, Cristian Melo, Nestor Acosta, and Mauricio Gavilanes. 1997. Diagnostico de linea base de las especies de flora y fauna asociadas al sistema agroforestal de cacao en las cooperativas El Progreso y Nueva Union Campesina. Quito. http://www.scribd.com/doc/23761790/ESTUDIO-DE-BIODIVERSIDAD-ENEL-CACAO-CONSERVACION-DESARROLLO.

Rohsius, Christina, Reinhard Matissek, and Reinhard Lieberei. 2005. Free amino acid amounts in raw cocoas from different origins. European Food Research and Technology 222(3-4): 432-438.

Rosales Valenzuela, Benjamin. 2010. Repunte cacaotero. El Comercio. Quito, August 23 2010 .

Rosero, Jose Luis. 2002. Apuntes de Economia No 20: La ventaja competitiva del Cacao Ecuatoriano. Guayaquil: Direccion General de Estudios del Banco Central del Ecuador. Accesed online March 202010 http://www.bce.fin.ec/documentos/PublicacionesNotas/Competitividad/Estudios/a e20.pdf.

Sanches, C. L. G., L. R. M. Pinto, A. W. V. Pomella, S. D. V. M. Silva, and L. L. Loguercio. 2008. Assessment of resistance to Ceratocystis cacaofunesta in cacao genotypes. European Journal of Plant Pathology 122(4): 517-528. 
Seyfang, Gill. 2006. Ecological citizenship and sustainable consumption: Examining local organic food networks. Journal of Rural Studies 22(4): 383-395.

Sierra, Rodrigo, and Jody Stallings. 1998. The dynamics and social organization of tropical deforestation in Northwest Ecuador, 1983-1995. Human Ecology 26(135161.

Soluri, John. 2000. People, Plants, and Pathogens: The Eco-social Dynamics of Export Banana Production in Honduras, 1875 1950. Hispanic American Historical Review 80(3): 463-501.

Southgate, Douglas, and Morris Whitaker. 1992. Promoting resource degradation in Latin America: tropical deforestation, soil erosion, and coastal ecosystem disturbance in Ecuador. Economic Development and Cultural Change 40(4): 787-807.

Zhang, Dapeng, Sue Mischke, Elizabeth S. Johnson, Wilbert Phillips-Mora, and Lyndel Meinhardt. 2008. Molecular characterization of an international cacao collection using microsatellite markers. Tree Genetics \& Genomes 5(1): 1-10.

von Rutte, Samuel. 2004. Presecado del cacao en baba: Un nuevo concepto en fermentacion. Guayaquil: Author. 


\section{CHAPTER V.}

\section{CONCLUSION}

This study was born out of turning the definition of sustainable development into a question: if it is a "development that meets the needs of the present without compromising the ability of future generations to meet their own needs" (Brundtland 1987), there is a need to ask about whose present and whose future is represented into the implementation of this multigenerational project (Luke 2005).

The aims of this study were: a) to understand to what is chocolate manufacturers' perception of what consumers are looking for-what are the qualities that made alternative goods, b) to understand how the perception of consumer's demand for sustainability-enhanced chocolate is translated into the implementation of cocoa-centered development projects, c) to understand how the implementation of these projects ignores the impacts that these efforts impose on the farmers.

In Chapter II, I show that chocolate wrappers' narratives are rich in keywords which denote sustainability (i.e., nature, rainforest and farmers), a finding that suggest that manufacturers are designing products to meet the demand of consumers for alternative chocolate. However, the mechanisms for the sourcing of this alternative cocoa are not stated in the labels of most products. Half of the manufacturers use a countrywide definition of origin, paying a token attention to the farmers in the ground. Certification — when present—does not imply the presence of a deep relationship between producers and manufacturers. Certification acts as a barrier to entry at the producer's level (limiting the number of cocoa suppliers for a particular bar), but manufacturers source cocoa from any certified producer. The use of country-wide sourcing, and the lack of 
commitment of manufacturers also suggest that manufacturers perceive that most consumers are satisfied with vague references to "geographical sourcing," "protectingthe-environment" and "supporting-the-farmers." Vague commitments to alternative-trade sourcing create risks for chocolate manufacturers - as well as for cocoa producers. From the chocolate manufactures perspective, companies that work closely with farmers-and are willing to commit time and resources to cultivate these relationships - are likely to secure access to a supply of high-quality beans. On the other hand, companies that opt out of developing relationships with the producers will find themselves engaged in an endless race to secure high quality beans. At-length cocoa sourcing puts artisan companies in direct competition with the large candy multinationals, which are quite interested in entering into these niche markets and sourcing high-quality cocoa (i.e., Kraft, Hershey's and Lindt).

At-length alternative trade cocoa sourcing also creates risks for producers' organizations. In Chapter III, I show the effects that a producers' "at-length" alternativetrade strategy had on the Ecuadorian Federation of Cocoa Producers (FEDECADE). In 2009 , the commercialization system of FEDECADE ceased to operate after the FEDECADE was unable to find a client willing to pay a premium price for its multicertified Nacional cocoa. This collapse, after just six years of operation, marked the end of a thirteen-years-long (1995-2008) effort financed with over a million dollars of investment by international donors The project achieved its generic goal of increasing the income of farmers by creating an alternative commercialization system that transferred revenues from cocoa exports directly to the farmers. The alternative commodity chain organized by FEDECADE gave farmers an attractive outlet for their products, and forced 
intermediaries to rationalize their profitability. These benefits were lost when in 2009 FEDECADE was not able to secure a purchase order, because it lacked a strategic partner. FEDECADE's approach towards commercialization was to for sell cocoa to the highest bidder - the farmer's equivalent to chocolate manufacturers "at-length" cocoa sourcing. The sell-to-the-highest-bidder strategy generated revenues in the short term, but did not lead to long-term sustainability.

The experience of FEDECADE shows another risk of "at-length" alternative trade. The collapse of FEDECADE's RA certified cocoa market, after Kraft Foods Inc. started to source RA cocoa from Ivory Coast (Africa), suggests that certification-the basic tool of alternative trade — do not guarantee sustainability. Certified farmers face diminishing returns as more farmers join certification programs - lured as they are by the promises of NGOs and IGOs with worldwide outreach. In fact, the same actors (Rainforest Alliance-Kraft-GTZ) financed the efforts of FEDECADE in Ecuador, as well as the efforts of the farmers of Ivory Coast. When the supply of certified goods outpaces demand, the premiums for certified goods collapse. The race for certification benefits multinational companies, which have the ability to source commodities from the lowest (or more convenient) supplier: certified products become another commodity, subject to cycles driven by supply and demand.

The FEDECADE case also raises doubts about the viability of pairing developing-country organizations with global financial partners. In these relationships, the burden of risk is carried by those in developing economies. When FEDECADE's U.S. financial partner (Root Capital) deemed that the cocoa business was too risky, it pulled out. FEDECADE was not able to find another source of capital. There is a power 
differential between financers and producers, and certainly points to the vulnerability of the developing country partners in these alliances.

Finally, FEDECADE's experience also shows the failings of leveraging development on a commodity like cocoa, subject to the whims of the international markets. Cocoa prices and stocks have been fluctuating widely in the global markets, reaching historical heights only to fall vertiginously. The behavior of Northern stockholders, from small investors to the Armajaro Hedge Fund, have deep repercussions on the livelihoods (and hopes) of commodity-producing farmers in the developing world. Thus, successful commodity-based development programs exacerbate rural communities' exposure to these risks.

Finally, the results of my study indicate that the NGOs and IGOs behind the FEDECADE project have not succeeded at convincing farmers to remain wedded to Nacional. Only one out of the 100 farmers I interviewed replanted his farm with Nacional, and that was done eight years ago. Meanwhile, in the last seven years (within the period of execution of the projects) 38 farmers (out of 100) had renovated their plantations using CCN-51, a high-yield full-sun cocoa hybrid that lacks the Nacional flavor. These data suggest that even when the stock centers paid premium prices for Nacional, farmers were voicing their choice for agricultural intensification by planting CCN-51.

In Chapter IV, I address the reasons that explain why most farmers opt for the CCN-51 variety. I found that crop diversification strategies exert a strong influence in farmer's income. Farmers with more types of crops fare better, because the other crops replace or supplement the income from cocoa. The responses to my survey suggest that 
farmers see the $\mathrm{CCN}-51$ cocoa variety as another source of income. The $\mathrm{CCN}-51$ variety is attractive because its yield by area is up to three times the yield of Nacional. In the FEDECADE general area-whose farmers had the support of Nacional-oriented NGO projects for the last 10 years - CCN-51 yields $721 \mathrm{~kg} / \mathrm{ha}$ year to Nacional $379 \mathrm{~kg} / \mathrm{ha}$ year. In the APOV general area CCN-51 yields are higher (354 kg/ha year) than the average Nacional' (295 kg ha/year) even thought the CCN-51 plots have not yet reached full production. Farmers are aware that $\mathrm{CCN}-51$ is more costly, and that it requires more 'care,' but they said that this variety's yield compensates them for the extra investment.

The farmers' overall preference for the CCN-51 variety is because in the regional markets a farmer gets paid the same price for both varieties (but CCN-51 yield is higher than the yield of Nacional). In cases when the farmer is associated with a 'certified' associative commercialization organization that manages to get a differentiated price for Nacional cocoa, the amount of the premium does not compensate the farmer for the low yield of this variety.

The results of my study suggest that Nacional lacks profitability. The results also indicate that there are two ways in which this variety could survive. First, if farmers are making a decent living out of other crops, some of them may opt for conserving Nacional for its aesthetic values. Also, in some cases Nacional holdings are in hands of professionals (i.e., teachers, doctors, and economists) that reported that the largest share of their income came from their professional occupations, and that cocoa was secondary. These professionals liked Nacional, because it is easy to keep.

In conclusion, in Chapter IV my study shows weaknesses in the conceptualization and implementation of the alternative trade and the agricultural intensification models in 
the context of Ecuadorian cocoa production. Alternative trade — derived from ecological or environmental friendly certification schemes, or in varietal attributes —offers at best a limited tool to address poverty, unless accompanied by a strong agricultural intensification component. In Ecuadorian cocoa, low yield does not lead to profitability. Farmers have ways of increasing income that challenge the conventional view of agricultural intensification as 'one crop.' Farmers use their knowledge of local markets, their abilities, labor availability, and other agricultural, social and economic variables in ways that it maximizes their opportunities and minimizes risks: most the farmers in my survey were the survivors of three or more decades of cocoa price swings, botched government price fixing schemes, ${ }^{58}$ weather phenomena, and fickle markets. For some, their response is opting for one high yield variety $(\mathrm{CCN}-51)$; for others, planting crops other than cocoa. Even more opt for having Nacional, CCN-51 and other crops.

Evidently, this suggests the need for a reevaluation of 'one-crop' development programs. While this sort of projects — on the basis of the expertise of a selected group, easily framed in terms of problems and solutions - are attractive for development agencies, they lack a farmer's nuanced understanding of the local growing conditions. This understanding — the knowledge of each farmer about himself, his land, the crops —is lost when an externally-financed solution are applied wholesale. A common complaint among Ecuadorian environmentalists is that agrochemicals are used "en plancha" (in all the area of a plantation). Paradoxically, these groups apply 'sustainable development' and 'certification' projects in the same way.

${ }^{58}$ From farmer's perspective. 
The findings also point out to other failings in the contemporary discourse on Ecuadorian cocoa production. Indeed, the middlemen are part of the problem. However, instead of just ignoring them (at best) or demonizing them, there is a need to see them as part of the solutions: if an associative commercialization system is lacking, the middlemen — and their practices—remain. If the goal of a policy maker is to improve the quality of Ecuadorian cocoa, there is a need to train these agents in assessment of cocoa, following rules and procedures that are as strict as those imposed to the associative farmers.

Finally, there is a need to attack structural problems that cannot be solved by alternative trade or agricultural intensification models. There is a lack of credit for cocoa, given banker's perception of the low profitability of cocoa—and farmers cannot improve their farms because they lack credit. If some of the resources used in promoting alternative trade had been used instead in a fund for granting low-interest, 10 -year term loans, more farmers would have been able to improve their farms in ways that would have allowed them to increase their incomes. As it is working, alternative trade does reward farmers for non-transactional goods and services (i.e., ecosystem services). The premiums that the market would bear are subject to supply and demand; while a farmer's lost opportunities remain constant. Thus, farmers bear the cost of providing these services.

In summary, my findings suggest that manufacturers perceive that most consumers are satisfied with vague references to "geographical sourcing," "protectingthe-environment" and "supporting-the-farmers." This vague commitment to alternativetrade sourcing — which I call "at-length" alternative trade—create risks for chocolate 
manufacturers as well as for cocoa producers. Companies that opt out of developing relationships with the producers will find themselves engaged in an endless race to secure high quality beans, and in direct competition with the large candy multinationals, which are quite interested in the alternative trade niche markets.

I also found that the implementation of "at-length" alternative trade-sustainable development projects at the producers' side offer at best a mixed bag of success and failures. After 13 years and over a million-dollar investments that propped an alternative trade effort with the broad goal of addressing poverty by raising farmers' income, I found that farmers' incomes got a temporary boost from alternative trade. These projects achieved the goal of forcing cocoa middlemen and exporters to rationalize their behavior, transferring a larger share of cocoa market value to the farmers. However, by 2009 this effort collapsed. The collapse is partially explained because the FEDECADE (the farmers' organization involved in this project) opted for the producers' version of "atlength" alternative trade, selling certified cocoa to the highest bidder. The lack of commitment of producers' groups mirrors the lack of commitment of chocolate manufacturers. The FEDECADE commercialization system failure the evidence suggest that alternative-trade and premium commodities remain subject to supply and demand. Farmers face diminishing gains as more farmers opt for certification. A worldwide race for achieving certification actually benefits multinational corporations, which regain the power to source commodities from the lowest cost (or most convenient) supplier. In addition, the results question the strategy of leveraging sustainable development projects on a commodity, subject to the whims of the international markets. Even if successful, these projects only exacerbate rural communities' exposure to these risks. Finally, the 
results show how power plays a role at setting the terms, goals and results of sustainability partnerships. It is necessary to remember that funding institutions (international agencies, non-profits, and the likes) decide which projects are financed. Rhetorical price of partnership aside, sustainable development projects are biased towards the agenda of these agencies — and their perceptions of the wishes of Northern consumers.

Finally, the results of my study show a linkage between poverty and farmer's reliance in the low yield fine cacao known as Nacional— the darling of alternative traders. I found that the premiums paid for this variety_-fine cocoa, shade-grown, organic, certified-do not compensate farmers for the low yield. Plain and simple, Nacional lacks profitability. Even more, outside of associative commercialization systems, farmers get the same gate price for both varieties. These findings point out to a new consideration of alternative trade schemes. Alternative trade should be seen as a way to fund a selffinanced farmer's organization that provides services to farmer's groups. The goal of this association must be to help farmers optimize their activities, via agricultural intensification, crop diversification and similar local thought schemes. If equality and fairness are put at the forefront, it is not fair that farmers bear the costs of the ecological services of shaded plantations - if the cost of this keeping is that they remain in poverty.

Thus, the findings of this study point at the need for careful assessment of whether the needs of the present generation are being met. Self-reliance and selfawareness are part of the way of farming: the cocoa farmer's in my sample have survived to 30 -years or more of commodities volatility, changes government, social upheaval, and fickle markets. Alternative trade/sustainable development projects emphasis on 
consensus, expertise, instrumentality, and pursuit of Northern consumer's via certification forfeits the values of farmers' experiences - thus fail. After all — when the funding for projects dries up and the army of NGO's and IGO's consultants move towards greener pastures - the farmers are who remain in the land, left behind. 


\section{REFERENCES}

Brundtland, G.H. 1987. Our common future [The Brundtland report]. World Commission on Environment and Development. Oxford; New York: Oxford University Press.

Luke, TW. 2005. Neither sustainable nor development: reconsidering sustainability in development. Sustainable Development 13: 228-238. 


\section{APPENDIX 1}

SURVEY

ABANDONADOS: EL DESTINO DE LOS AGRICULTORES EN LA ERA DEL

DESARROLLO SUSTENTABLE

Cristian Melo

Department of International Relations

Florida International University

University Park DM 430

11200 SW $8^{\text {th }}$ Street,

Miami F1 33199

Genero: $\square$ Hombre $\square$ Mujer $\square$ Edad:

1. Localidad y Afiliación

1.1 Localidad/Cooperativa/Asociación:

1.2 Afiliación: $\square$ FEDECADE $\square$ APOV INDEPENDIENTE/NINGUNA

Otro Grupo Cacaotero:

1.3 Donde nacio?

1.4 Si nacio en otro sitio (fuera del area), hace cuanto tiempo vive aqui? años.

1.5 Esta pregunta es sobre tenencia de tierra. Como adquirio sus tierras? Heredo, compro, arrienda, o le dieron tierra por reforma agraria?

1.6 Sus padres era cacaoteros, o tenian otra actividad?

1.7 Y cuando usted ya no este, quien cree que va a trabajar la tierra? A alguno de sus hijos le interesa la agricultura, o tienen otras profesiones? 
2. Extensión, tenencia y uso del suelo

2.1 Cuanta tierra tiene, maneja o renta usted (anotar respuesta)? Unidad:

2.2 Conversión a hectáreas

2.3 Tenencia de tierra: $\square$ PROPIA $\square$ RENTA $\square$ COMUNAL

$\square$ Otra: Si renta, puedo preguntarle cuanto paga por la tierra?

2.4 Que cultivos tiene y que superficie de la tierra dedica a este cultivo?

\begin{tabular}{|l|l|l|l|l|}
\hline Cultivo & Superficie & Unidad & Edad & Superficie \\
\hline (años) & & & (has) \\
\hline 2.4.1 $\square$ Cacao Nacional $\square$ Cacao CCN5 & & & & \\
\hline VARIEDAD/es: $(*)$ & & & & \\
\hline 2.4.4 $\square$ Banano en Huerta & & & & \\
\hline 2.4.5 $\square$ Banano Separado & & & & \\
\hline 2.4.6 Otro 1: & & & & \\
\hline 2.4.7 Otro 2 & & & & \\
\hline 2.4 .8 Otro 3 & & & & \\
\hline
\end{tabular}

2.4.3.1* Otras variedades:

2.5 Que plantas y arboles tiene usted para sombra de cacao (las mas comunes)?

3.1 En su opinión, cuales son los problemas que usted tiene con el cacao?

3.2 Hay diferencia entre el Nacional y el de ramilla CCN-51? Que tiene de bueno y malo cada una?

3.2.1 Que tiene de bueno el Nacional? 
3.2.2 Que tiene de malo?

3.2.3 Que tiene de bueno el ramilla $\mathrm{CCN}-51$ ?

3.2.4 Que tiene de malo?

3.3 Tiene usted en la finca? $\square$ Tendal de caña $\square$ Tendal de cemento

$\square$ Marquesina-secadora solar $\square$ Secadora a gas $\square$ Secadora a leña

Caja de fermentación

3.4 Como y donde fermenta el cacao? Cuanto se demora? Cual es el precio de cacao fermentado respecto al precio de cacao sin fermentar?

3.5 Como y donde seca el cacao? Cuanto se demora? Cual es el precio de cacao seco respecto al precio de cacao fresco?

3.6 Tiene alguna ventaja tiene vender cacao fermentado y secado? No?

3.7 Cuanto tiempo le dedica al cultivo en dias por mes? dias

3.8 Trabaja solo? Le ayuda alguien mas?

4. Production, costos y rendimiento

\begin{tabular}{|l|l|l|l|}
\hline Cultivo & $\begin{array}{l}\text { Rendimiento } \\
\text { (qq/ha/año o } \\
\text { cajas/ha/año) }\end{array}$ & postos de & Ultimo fecha y \\
\hline $4.1 \square$ Cacao Nacional & & precio de venta \\
\hline $4.2 \square$ Cacao CCN- & & & \\
$51 /$ Ramilla & & & \\
\hline $4.3 \square$ Cacao OTRA/s & & & \\
VARIEDAD/es: $(*)$ & & & \\
\hline
\end{tabular}




\begin{tabular}{|l|l|l|l|}
\hline $4.4 \square$ Banano en Huerta & & & \\
\hline $4.5 \square$ Banano Separado & & & \\
\hline 4.6 Otro 1: & & & \\
\hline 4.7 Otro 2 & & & \\
\hline 4.8 Otro 3 & & & \\
\hline
\end{tabular}

4.9 Donde generalmente vende el cacao? Que tanto del total vende en este sitio? Que tal es el precio? Le pagan mas por Nacional? Lo mismo que por el CCN-51?

4.10 Hay otro/otros sitios donde vende cacao? Que tanto del total vende en este sitio?

Que tal es el precio? Le pagan mas por Nacional? Lo mismo que por el CCN-51?

5. Otros Ingresos

5.1 A parte del cacao, tiene usted otra fuente de ingreso? Trabaja en una bananera, en una hacienda, otra actividad? $\square$ SI $\square$ NO

$5.2 \mathrm{Y}$ en que trabaja cuando se acaba la cosecha?

5.2.1 Que tan lejos es?

5.2.2 Y quien se queda en la finca?

5.3 Tiene usted acceso a préstamos antes de la cosecha? A un préstamo que se pague con cacao? 


\section{APPENDIX 2}

VARIABLE DEFINITION

\begin{tabular}{|c|c|c|c|}
\hline Variable & Description & Type & Coding \\
\hline GEN & Gender & Nominal & $\begin{array}{l}\text { F, FEMALE; M, } \\
\text { MALE }\end{array}$ \\
\hline AGE & Age & Continuous & \\
\hline PLA & Place & Nominal & $\begin{array}{l}\text { SDJ, } 6 \text { DE JULIO, } \\
\text { GUAYAS; LFL, LA } \\
\text { FLORIDA, AZUAY; } \\
\text { CAM, CAMACHO, } \\
\text { AZUAY; NUC, } \\
\text { NUEVA UNIÓN } \\
\text { CAMPESINA, } \\
\text { GUAYAS; VIN, } \\
\text { VINCES, LOS } \\
\text { RÍOS. }\end{array}$ \\
\hline AFL & Affiliation & Categorical & $\begin{array}{l}\text { 0, INDEPENDENT; } \\
\text { 1, FEDECADE; } 2 \text {, } \\
\text { APOV; } 3 \text {, UROCAL. }\end{array}$ \\
\hline BOR & Place of birth & Nominal & \\
\hline TOR & Time of residence & Continuous & \\
\hline OWN & Land ownership & Binary & \\
\hline REN & Rent or Lease amount (US\$/ha/year) & Continuous & \\
\hline WOO & Way of ownership & Categorical & $\begin{array}{l}\text { BOUGHT, } \\
\text { BOUGHT AND } \\
\text { INHERITED; } \\
\text { BOUGHT AND } \\
\text { LAND REFORM; } \\
\text { BOUGHT, LAND } \\
\text { REFORM AND } \\
\text { RENT; GIFT; } \\
\text { INHERITANCE; } \\
\text { INHERITANCE } \\
\text { AND LAND } \\
\text { REFORM; LAND } \\
\text { REFORM; LOAN; } \\
\text { RENT. }\end{array}$ \\
\hline RCG & Relatives were cacao growers & Binary & \\
\hline RFG & Relatives were farmers (other crops) & Binary & \\
\hline PCG & $\begin{array}{l}\text { Expectations about progeny } \\
\text { remaining cocoa growers }\end{array}$ & Binary & \\
\hline FRA & Number of plots owned & Continuous & \\
\hline
\end{tabular}




\begin{tabular}{|c|c|c|c|}
\hline Variable & Description & Type & Coding \\
\hline SUR & Surface owned (total) & Continuous & \\
\hline NAC & Farmer grows cacao Nacional & Binary & \\
\hline AGN & Nacional groove age (average years) & Continuous & \\
\hline SUN & Nacional groove surface (ha) & Continuous & \\
\hline $\mathrm{CCN}$ & Farmer grows cacao CCN-51 & Binary & \\
\hline AGC & $\mathrm{CCN}-51$ groove age (average years) & Continuous & \\
\hline SUC & Nacional groove surface (ha) & Continuous & \\
\hline BAN & $\begin{array}{l}\text { Farmer has banana associated with } \\
\text { cacao }\end{array}$ & Binary & \\
\hline SUB & $\begin{array}{l}\text { Associated banana/cacao groove } \\
\text { surface (ha) }\end{array}$ & Continuous & \\
\hline OCR1 & $1^{\text {st }}$ other crop & Binary & \\
\hline OCT1 & $1^{\text {st }}$ other crop type & Nominal & \\
\hline OCS1 & $1^{\text {st }}$ other crop surface (ha) & Continuous & \\
\hline OCR2 & $2^{\text {nd }}$ other crop & Binary & \\
\hline OCT2 & $2^{\text {nd }}$ other crop type & Nominal & \\
\hline OCS2 & $2^{\text {nd }}$ other crop surface (ha) & Continuous & \\
\hline OCR3 & $3^{\text {rd }}$ other crop & Binary & \\
\hline OCT3 & $3^{\text {rd }}$ other crop type & Nominal & \\
\hline OCS3 & $3^{\text {rd }}$ other crop surface (ha) & Continuous & \\
\hline SHA & Farmer has shade-grown cacao & Binary & \\
\hline $\cos$ & $\begin{array}{l}\text { Shadow complexity (number of } \\
\text { species mentioned during survey) }\end{array}$ & Continuous & \\
\hline $\mathrm{INF}$ & Cacao post harvest infrastructure & Categorical & $\begin{array}{l}0, \text { NONE; } 1 \text {, } \\
\text { TENDAL DE } \\
\text { CEMENTO; } 2, \\
\text { SOLAR DRYER; } 3 \text {, } \\
\text { LPG DRYER; 4, } \\
\text { FERMENTATION } \\
\text { BOX }\end{array}$ \\
\hline FER & Farmer ferment cacao (any method) & Binary & \\
\hline DIF & $\begin{array}{l}\text { Difference on price for fermented } \\
\text { cacao vs. non-fermented cacao }\end{array}$ & Categorical & $\begin{array}{l}\text { 0, NO;1, YES;-, does } \\
\text { not answer/does not } \\
\text { know }\end{array}$ \\
\hline DRY & Farmer dries cacao before sale & Binary & \\
\hline TIM & $\begin{array}{l}\text { Time dedicated to cacao } \\
\text { (days/month) }\end{array}$ & Continuous & \\
\hline SLA & Source of farm labor & Categorical & $\begin{array}{l}0, \text { works alone; } 1 \text {, } \\
\text { works with family } \\
\text { help; } 2 \text {, hires labor; } \\
3, \text { both family help } \\
\text { and hired labor }\end{array}$ \\
\hline YIN & Nacional cacao yield (qq/ha/year) & Continuous & \\
\hline
\end{tabular}




\begin{tabular}{|c|c|c|c|}
\hline Variable & Description & Type & Coding \\
\hline $\mathrm{DAN}$ & Nacional last cacao sale & Continuous & \\
\hline SPN & $\begin{array}{l}\text { Nacional last sale price (in US\$ per } \\
\text { qq) }\end{array}$ & Continuous & \\
\hline YIC & CCN-51 cacao yield (qq/ha/year) & Continuous & \\
\hline $\mathrm{DAC}$ & CCN-51 Date of last cacao sale & Continuous & \\
\hline SPC & $\begin{array}{l}\text { CCN-51 Last sale price (in US\$ per } \\
\text { qq) }\end{array}$ & Continuous & \\
\hline POS & Place of sale & Categorical & $\begin{array}{l}0, \text { farm's gate; } 1 \text {, } \\
\text { town middleman; } 2 \text {, } \\
\text { exporter; } 3 \text {, farmer's } \\
\text { association; } 4 \text {, both } 1 \\
\text { and } 2\end{array}$ \\
\hline OPS & Other place of sale & Binary & \\
\hline SEC & $\begin{array}{l}\text { Farmer has another economic } \\
\text { activity }\end{array}$ & Binary & \\
\hline TSE & Type of another economic activity & Categorical & $\begin{array}{l}\text { 0, none; } 1 \text {, farming } \\
\text { (other crops); } 2 \text {, labor } \\
\text { for neighbors; } 3 \text {, crab } \\
\text { artisanal industry } \\
\text { (fishing or } \\
\text { processing) 4, } \\
\text { transportation } \\
\text { industry } \\
\text { (taxis/pickups); 5, } \\
\text { commerce/sales; } 6 \text {, } \\
\text { construction worker; } \\
\text { 7, arts; } 8 \text {, services; } 9 \text {, } \\
\text { teacher, government } \\
\text { or municipal } \\
\text { employee; } 10 \text {; other }\end{array}$ \\
\hline ATL & Access to loans & Binary & \\
\hline
\end{tabular}




\section{APPENDIX 3}

\section{INTERNAL REVIEW BOARD MEMO}

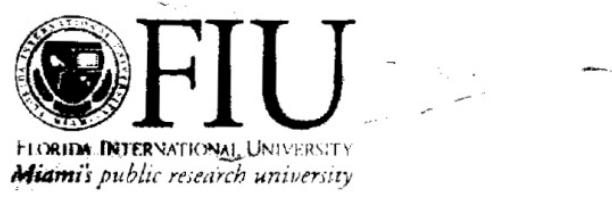

Office of Research Integrity
Research Compliance, MARC 430

Miamis public reseairch universit.

\section{MEMORANDUM}
To:
Cristian Melo
CC:
Dr. Gail Hollander
From:
File
Date:
Chris Grayson, CIM, Asst. Director of Research Compliance

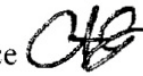
Proposal Title: $\quad$ Left Behind: A Farmer's Fate In The Age Of Sustainable Development.
Approval \# 022009-01

Your study was deemed Exempt by the Institutional Review Board at Florida International University on February 20, 2009.

As a requirement of IRB approval you are required to:

1) Submit a completion report (Form B-2) upon completion of your project in order for the file to be closed.

2) Submit a proposal and receive approval for any additions or changes in the procedures involving human subjects.

3) Provide immediate written notification to the IRB of every serious or unusual or unanticipated adverse event as well as problems with the rights or welfare of the human subjects. You must confirm the receipt of serious AE reports with the IRB office.

Special Conditions: N/A

Please note your approval number is indicated above. For further information, you may contact the IRB Coordinator by email at irbiacuc@fiu.edu or visit the ORI - Human Subjects website at http://ori.fiu.edu/IRB.html. 
VITA

\section{CRISTIAN JAVIER MELO}

$1990-2000$

B.Sc. Biology

Pontificia Universidad Catolica del Ecuador

Quito, Ecuador

2000 Samuel Valarezo Award

1997-2002

Projects

Conservacion y Desarrollo

Quito, Ecuador

2002-2004

Fulbright Grantee

2002-2004

M.Sc. Natural Resources Management and Policy

Cornell University

Ithaca, New York

2005-2008

M.A. International University

Florida International University

Miami, Florida

2007

Specialty Graduate Course in Tropical Agroecology Organization for Tropical Studies

San Jose, Costa Rica

2009

Dissertation Evidence Acquisition Fellowship, FIU South Florida Chapter of the Explorers Club Grant Field Research Grant FIU LACC Tinker Foundation, Inc

2010

Dissertation Year Fellowship, FIU

\section{PUBLICATIONS AND PRESENTATIONS}

Melo, C. Avifauna asociada a Cedrelinga cateniformis (Mimosaceae) en el Parque Nacional Yasuní, Amazonía Ecuatoriana [Birds associated with Cedrelinga catenaeformis at the Yasuni National Park, Ecuadorian Amazonia], XXIV Ecuadorian Biology Congress (2000), Quito, Ecuador.

Melo, C. Avifauna asociada a Cedrelinga cateniformis (Mimosaceae) en el Parque Nacional Yasuní, Amazonía Ecuatoriana [Birds associated with Cedrelinga catenaeformis at the Yasuni National Park, Ecuadorian Amazonia]. In: Abstracts of the Ecuador's Third Botanical Congress, Quito, October 25-27 of 2000 (ed. Mercedes 
Asanza, Alina Freire Fierro, David Nelly, Sonia Sandoval and Joseph C. Welling). FUNBOTANICA and Herbario Nacional del Ecuador: Quito.

De Vries, T. and Melo, C. 2000. First nest description of Slaty-Backed Forest Falcon at the Yasuni National Park, Ecuadorian Amazonia. Journal of Raptor Research 34: 148150

Melo, C and Wolf, S. 2005. Empirical assessment of Eco-certification: the case of Ecuadorian bananas. Organization \& Environment 18: 287-317

Melo, C. and Hollander, G. Arriba Ecuador! Protected Denominations of Origin and the Case of Ecuadorian Arriba Cacao (oral presentation). The 2007 Cultivating Appetites for Knowledge Joint Meeting of Agriculture and Human Values Society and Association for the Study of Food and Society. The University of Victoria: Victoria.

Melo, C and Wolf, S. 2007. Eco-certification of Ecuadorian bananas: Prospects for progressive North-South linkages. Studies in Comparative International Development 42: $256-278$

Melo, C. and Hollander, G. Ecuadorian "Arriba" Cacao: Local empowerment and successful alternative trade networks. The 2009 Informing Possibilities for the Future of Food and Agriculture Joint Meeting of Agriculture and Human Values Society and Association for the Study of Food and Society. Penn State University: State College, PA. 